\title{
Representação de sistemas biológicos a partir de sistemas dinâmicos: Controle da transcrição a partir do estrógeno
}

\section{Marcelo Ris}

\author{
Tese Apresentada ao Programa Interunidades em Bioinformática \\ da Universidade de São Paulo \\ para a obtenção do Grau de Doutor em Bioinformática
}

\author{
Área de Concentração: Bioinformática \\ Orientador: Prof. Dr. Junior Barrera \\ Co-orientadora: Profa. Dra. Helena Brentani
}

Durante a elaboração deste trabalho, o autor recebeu apoio financeiro da CAPES, da Texas A\&M University e do NIH.

São Paulo

2008 



\section{Representação de sistemas biológicos a partir de sistemas dinâmicos: Controle da transcrição a partir do estrógeno}

Este exemplar corresponde à redação da tese, apresentada e defendido por

Marcelo Ris à comissão julgadora.

São Paulo, 14 de abril de 2008.

Banca examinadora:

- Prof. Dr. Junior Barrera (Orientador) - Instituto de Matemática e Estatística, USP, São Paulo(SP), Brasil

- Prof. Dr. Roberto Marcondes César Júnior - Instituto de Matemática e Estatística, USP, São Paulo(SP), Brasil

- Prof. Dr. Alexandre Xavier Falcão - Instituto de Computação, Unicamp, Campinas(SP), Brasil

- Prof. Dr. Roger Chammas - Faculdade de Medicina, Departamento de Radiologia, USP, São Paulo(SP), Brasil

- Profa. Dra. Maria Aparecida Azevedo Koike Folgueira - Faculdade de Medicina, Departamento de Radiologia, USP, São Paulo(SP), Brasil

Orientador:

- Prof. Dr. Junior Barrera (Orientador) - Instituto de Matemática e Estatística, USP, São Paulo, Brasil

- Profa. Dra. Helena Brentani (Co-orientadora) - Hospital do Câncer, São Paulo, Brasil 



\section{Agradecimentos}

Ao meu pai, Isaac, a quem devo toda a minha educação e tudo o que tive e tenho na minha vida,

Ao Prof. Dr. Junior Barrera, de quem pude contar com a sua valiosa orientação de meu trabalho,

À Profa. Dra. Helena Brentani, de quem pude contar com a sua valiosa orientação na parte biológica do trabalho,

Ao Prof. Dr. Roberto Marcondes Cesar Junior, pela contribuição na parte matemática,

À Banca Examinadora, pela cuidadosa leitura e pelas correções,

Ao David Martins pelos testes do algoritmo aplicado à imagens,

A minha mãe, Léia, e meu segundo pai, Arnaldo, que foram meus grandes conselheiros em todos os momentos da minha vida,

A minha segunda mãe, Helena, que me criou como seu filho e a quem eu tenho o maior orgulho,

Aos meus irmãos, Fernando e Márcia, e meu cunhado, Marcelo, companheiros sempre,

Aos meu sobrinhos, Daniel e Michelle, que amo muito e deixam minha vida mais alegre,

A todos os meus colegas de estudo que me ajudaram muito nestes anos de estudo,

A todos meus amigos que me incentivaram,

A todos os professores dos institutos envolvidos,

E a CAPES, pela bolsa,

o meu sincero agradecimento.

Marcelo Ris. 



\section{Resumo}

Esta pesquisa de doutorado apresenta resultados em três áreas distintas: (i) Ciência da Computação e Estatística - devido ao desenvolvimento de uma nova solução para o problema de seleção de características, um problema conhecido em Reconhecimento de Padrões; (ii) Bioinformática - em razão da construção de um método baseado em um pipeline de algoritmos, incluindo o de seleção de características, visando abordar o problema de identificação de arquiteturas de redes de expressão gênica; e (iii) Biologia - ao relacionar o estrógeno com uma nova função biológica, após analisar informações extraídas de séries temporais de microarrays pelas novas ferramentas computacionais-estatísticas desenvolvidas.

O estrógeno possui um importante papel nos tecidos reprodutivos. O crescimento das gândulas mamárias e do endométrio durante a gravidez e o ciclo menstrual são estrógeno dependentes. O crescimento das células tumorais nesses órgãos podem ser estimuladas pela simples presença de estrógeno; mais de 300 genes são conhecidos por terem regulação positiva ou negativa devido a sua presença. A motivação inicial desta pesquisa foi a construção de um método que possa servir de ferramenta para a identificação de genes que tenham seu nível de expressão alterado a partir de uma resposta induzida por estrógeno, mais precisamente, um método para modelar os inter-relacionamentos entre os diversos genes dependentes do estrógeno.

Apresentamos um novo pipeline de algoritmos que, a partir de dados temporais de microarray e um conjunto inicial de genes que compartilham algumas características comuns, denominados de genes sementes, devolve como saída a arquitetura de uma rede gênica representada por um grafo dirigido. Para cada nó da rede, uma tabela de predição do gene representado pelo nó em função dos seus genes preditores (genes que apontam para ele) pode ser obtida. O método foi aplicado em estudo de série-temporal de microarray para uma cultura de células $T$-47D submetidas a tratamento com estrógeno, e uma possível rede de regulação foi obtida. Encontrar o melhor subconjunto preditor de genes para um dado gene pode ser estudado como um problema de seleção de características, no qual o espaço de busca pode ser representado por um reticulado Booleano e cada um de seus elementos representa um subconjunto candidato. Uma característica importante desse problema é o fato de que para cada elemento existe uma função custo associada, e esta possui forma de curva em U para qualquer cadeia maximal do reticulado. Para esse problema, apresentamos um nova solução, o algoritmo $U$-curve. Esse algoritmo é um método do tipo branch-and-bound, o qual utiliza a estrutura do reticulado Booleano e a característica de curva em $U$ da função custo para explorar um subconjunto do espaço de busca equivalente à busca completa. Nosso método obteve excelentes resultados em eficiência e valores quando comparado com as heurísticas mais utilizadas (SFFS e SFS).

A partir de um método baseado no pipeline e de um conjunto inicial de genes regulados diretamente pelo estrógeno, identificamos uma evidência de envolvimento do estrógeno em um processo biológico ainda não relacionado: a adesão celular. Esse resultado pode direcionar os estudos sobre estrógeno e câncer à investigação de processo metastático, o qual é influenciado por genes relacionados à adesão celular. 


\begin{abstract}
This Phd. research presents in three distinct areas: (i) Computer Science and Statistics - on the development of a new solution for the feature selection problem which is an important problem in Pattern Recognition; (ii) Bioinformatics - for the construction of a pipeline of algorithms, including the feature selection solution, to address the problem of identification the architecture of a genetic expression network and; (iii) Biology - relating estrogen to a new biological function, from the results obtained by the new computational-statistic tools developed and applied to a time-series microarray data.

Estrogen has an important role in reproductive tissues. The growth mammary glands and endometrial growing during menstrual cycle and pregnancy are estrogen dependent. The growth of tumor cells in those organs can be stimulated by the simple presence of estrogen. Over 300 genes are known by their positive or negative regulation by estrogen. The initial motivation of this research was the construction of a method that can serve as a tool for the identification of genes that have changed their level of expression changed by a response induced by estrogen, more specifically, a method to model the inter-relationships between the several genes dependent on estrogen.
\end{abstract}

We present a new pipeline of algorithms that from the data of a time-series microarray experiment and from an initial set of genes that share some common characteristics, known as seed genes, gives as an output an architecture of the genetic expression network represented by a directed graph. For each node of the network, a prediction table of the gene, represented by the node, in function of its predictors genes (genes that link to it) can be obtained. The method was applied in a study of time-series microarray for a cell line $T-47 D$ submitted to a estrogen treatment and a possible regulation network was obtained. Finding the best predictor subset of genes for a given gene can be studied as a problem of feature selection where the search space can be represented by a Boolean lattice and each one of its elements represents a possible subset. An important characteristic of this problem is: for each element in the lattice there is a cost function associated to it and this function has a U-shape in any maximal chain of the search space. For this problem we present a new solution, the $U$-curve algorithm. This algorithm is a branch-and-bound solution which uses the structure of the Boolean lattice and U-shaped curves to explore a subset of the search space that is equivalent to the full search. Our method obtained excellent results in performance and values when compared with the most commonly used heuristics (SFFS and SFS).

From a method based on the pipeline of algorithms and from an initial set of genes direct regulated by estrogen, we identified an evidence of involvement of estrogen in a biological process not yet related to estrogen: the cell adhesion. This result can guide studies on estrogen and cancer to research in metastatic process, which is affected by cell adhesion related genes. 


\section{Sumário}

1 Introdução 1

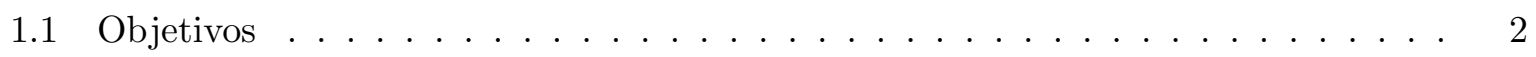

2 Estado da arte $\quad 5$

2.1 Sistemas dinâmicos . . . . . . . . . . . . . . . . . . . 5

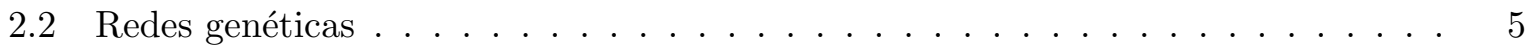

2.3 Rede genética probabilística . . . . . . . . . . . . . . . 6

2.4 Identificação do sistema . . . . . . . . . . . . . . . . . 8

2.5 O problema de seleção de características . . . . . . . . . . . . . . . 10

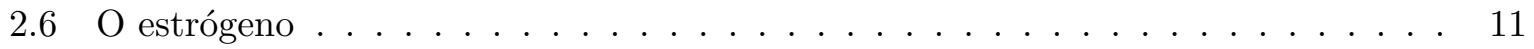

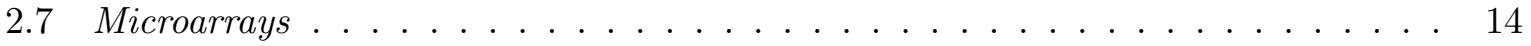

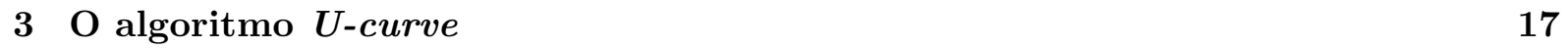

3.1 Otimização de curvas em $\mathrm{U} \ldots \ldots \ldots \ldots$

3.2 Descrição do método $U$-curve . . . . . . . . . . . . . . . . . . . 18

3.3 Fundamentos Matemáticos . . . . . . . . . . . . . . . . . . 26

3.3.1 Procedimento de obtenção dos elementos minimais e maximais . . . . . . 26

3.3.2 Atualização dos conjuntos de restrições . . . . . . . . . . . . . . . . . 31

3.3.3 Esgotamento do mínimo . . . . . . . . . . . . . . . . . . . . . . 32

3.4 Resultados experimentais . . . . . . . . . . . . . . . 33

3.5 Discussão . . . . . . . . . . . . . . . . . . . . . 36

4 O pipeline de algoritmos $\quad 39$

4.1 Descrição do método . . . . . . . . . . . . . . . . . . . . 40

4.2 Normalização e discretização . . . . . . . . . . . . . . . . . . . . 42

4.2.1 Análise do conjunto de genes-sementes . . . . . . . . . . . . . . 43 
4.2 .2 Função custo . . . . . . . . . . . . . . . . . . . . . . . . . . 44

4.2 .3 Melhor subconjunto preditor . . . . . . . . . . . . . . . 46

4.2 .4 Ordenação dos resultados ("ranking") . . . . . . . . . . . . . . 48

4.2 .5 Resultados experimentais . . . . . . . . . . . . . . . . 49

4.3 Discussão . . . . . . . . . . . . . . . . . . . . . . 50

4.4 Materiais e métodos . . . . . . . . . . . . . . . . . . 54

4.4.1 Série-temporal de microarray . . . . . . . . . . . . . . . . . 54

4.4 .2 Algoritmos . . . . . . . . . . . . . . . . . . 55

$\begin{array}{lll}5 & \text { O Estrógeno e a adesão celular } & 57\end{array}$

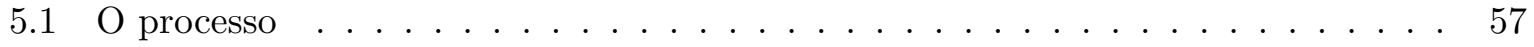

5.1 .1 Genes regulados diretamente por estrógeno . . . . . . . . . . . 58

5.1 .2 Genes resultantes . . . . . . . . . . . . . . . . . . . . 59

5.2 Discussão . . . . . . . . . . . . . . . . . . . . . . 66

5.3 Materiais e métodos . . . . . . . . . . . . . . . . . . 67

5.3 .1 Série-temporal de microarray . . . . . . . . . . . . . . . . . 67

6 Conclusão $\quad 69$

$\begin{array}{ll}\text { A Algoritmo U-curve } & 71\end{array}$

B Pipeline de Algoritmos $\quad 83$

$\begin{array}{lll}\text { C } & \text { Adesão celular } & 97\end{array}$

D Conteúdo do DVD 119

E Publicações e apresentações em eventos científicos $\quad 123$

E.1 Eventos científicos . . . . . . . . . . . . . . . . . . . . . . . . 124

E.2 Arigos em revistas . . . . . . . . . . . . . . . . . . . 125 


\section{Lista de Figuras}

2.1 Um exemplo de arquitetura de uma rede genética composta por 7 genes . . . . 6

2.2 Um exemplo de uma rede genética de 7 genes para 4 períodos de tempo $\ldots$. . . 7

2.3 Representação esquemática das 4 vias clássicas de ação dos receptores de estrógeno (Extraído do trabalho em $[4]$ ) . . . . . . . . . . . . . . . . 12

2.4 Representação tridimensional dos receptores de estrógeno (ER $\alpha$ e $\operatorname{ER} \beta)$. Ligados ao estrógeno: $\operatorname{ER} \alpha$-EST (Estradiol) ou $\operatorname{ER} \beta$-GEN (Genisteína); e ao Raloxifene (antagonista de estrógeno): ER $\alpha$-RAL ou ER $\beta$-RAL . . . . . . . . . . . 13

2.5 Representação esquemática de um experimento de série-temporal de microarray . 15

3.1 O espaço de busca em um reticulado Booleano de ordem 4. $\mathcal{X}$ é um poset obtido de $\mathcal{L}$, onde $\mathcal{X}=\mathcal{L}-\{0000,0010,0001,1110,1111\} \ldots \ldots \ldots \ldots$

3.2 As quatro possíveis representações da função custo $c$ restritas a algumas cadeias maximais em $\mathcal{L}$ e em $\mathcal{X} \subseteq \mathcal{L}$ da Figura $3.1 \ldots \ldots \ldots . \ldots . \ldots 20$

3.3 Representação esquemática de um passo do algoritmo U-curve. As áreas em destaque representam os elementos contidos nas restrições inferiores e superiores

3.4 Representação gráfica do processo de esgotamento do mínimo . . . . . . . . . . 27

3.5 Exemplos de curvas de erro com oscilações e caminhos alternativos . . . . . . . 33

4.1 Representação esquemática do pipeline de algoritmos . . . . . . . . . . . . . . . 40

4.2 Três exemplos de funções distribuição de probabilidades para uma variável aleatória discreta com três níveis de discretização . . . . . . . . . . . . . . . 44

4.3 Representação gráfica do estimador $\hat{P}_{\mathbf{A}}$ de uma função distribuição de probabilidade para um vetor de expressões $\mathbf{A} \ldots \ldots \ldots \ldots$

4.4 Representação de um reticulado Booleano de ordem 4 e a função custo associada a cada um de seus elementos . . . . . . . . . . . . . . . . 47

4.5 Grafo resultante obtido pela aplicação do pipeline ao experimento de série-temporal

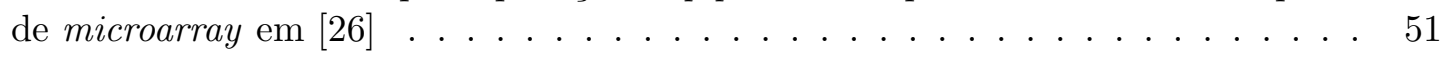

4.6 Página do banco de dados de "Stanford MicroArray" para o gene CDH17 . . . 52 
4.7 Quatro exemplos de tabelas de predições como uma página html, para uma parte da rede: gene HOXD10 com seus preditores e preditos . . . . . . . . . 53

4.8 Gráficos das expressões dos genes relacionados a cada uma das quatro tabelas de predições da Figura $4.7 \ldots \ldots \ldots$. . . . . . . . . . . . . . . . 53

5.1 Representação esquemática do processo utilizado no experimento . . . . . . . . 59

5.2 Gráfico da distribuição dos 53 genes-sementes por suas funções biológicas . . . . 62

5.3 Gráfico da distribuição dos 235 genes melhores preditos por suas funções biológicas 66

B.1 Representação esquemática do banco de dados . . . . . . . . . . . . . . . 96

C.1 Tabelas de predições dos genes relacionados à adesão celular . . . . . . . . . . . 116

C.2 Gráfico dos sinais dos genes relacionados à adesão celular . . . . . . . . . . . . . 117 


\section{Lista de Tabelas}

3.1 Comparação entre o resultado do SFFS e o algoritmo U-curve em nós calculados e tempo de execução para o desenho de W-operadores . . . . . . . . . . . . . 35

3.2 Comparação entre o resultado do SFFS e o algoritmo $U$-curve em nós calculados e tempo de execução para o problema de classificação biológica . . . . . . . . . 36

4.1 Exemplo de uma tabela de predição para o subconjunto de genes TBX21 e FRAT2 ao gene TGFBP3. . . . . . . . . . . . . . . . . . . 48

4.2 Exemplo de uma tabela de predição para o subconjunto de genes POU1F1 e EPAS1 ao gene TNFSF8. . . . . . . . . . . . . . . . . . 48

5.1 Lista $\operatorname{dos} 53$ genes-sementes . . . . . . . . . . . . . . . . . 61

5.2 Distribuição dos genes-sementes nos vários grupos de funções biológicas . . . . 62

5.3 Distribuição dos 235 genes preditos por suas funções biológicas . . . . . . . . . . 64

5.4 Lista dos 19 genes de adesão celular obtidos . . . . . . . . . . . . . . . . 65

B.1 Tabela com os 33 genes-sementes iniciais do resultado do pipeline . . . . . . . 86

B.2 Tabela com os 38 genes melhores preditos no primeiro passo . . . . . . . . . . 89

B.3 Tabela com os 37 genes melhores preditos no segundo passo . . . . . . . . . . 92

B.4 Tabela com os 38 genes melhores preditos no terceiro passo . . . . . . . . . 95

C.1 Lista dos 235 genes melhores preditos pelos genes-sementes da Tabela $5.1 \ldots 114$ 


\section{Capítulo 1}

\section{Introdução}

Modelar inter-relações de genes em uma rede genética específica é um dos estudos de maior desafio na área de sistemas biológicos. Existem inúmeros estudos que tentam modelar essas redes. Um resumo destes pode ser encontrado no trabalho de Dejong [21]. As redes podem ter fundamento na análise de regiões promotoras ou na análise de expressões gênicas (microarray e $S A G E$ ), e a partir desses dados a rede é construída. Uma rede genética (ou gênica) é caracterizada quando se conhece como a expressão de um conjunto de genes em um certo instante, afeta a expressão de outro em um instante subseqüente. Modelos de redes genéticas são representados por sistemas dinâmicos. O grafo orientado definido pelas componentes da função de transição que caracteriza o sistema dinâmico é chamado arquitetura da rede genética.

A motivação inicial deste trabalho foi a identificação de genes que tenham seu nível de expressão alterado a partir de uma resposta induzida por estrógeno. Além disso, desenvolver um método para modelar os inter-relacionamentos entre os diversos genes dependentes do estrógeno e, assim, obter uma rede genética. Modelando as redes genéticas por uma classe de sistemas dinâmicos estocásticos, denominado Redes Genéticas Probabilísticas (PGNs) [3], desenvolvemos, aqui, um novo método, descrito por um pipeline de algoritmos, para identificar a arquitetura de redes genéticas.

Estimar inter-relacionamentos entre genes nos remete a um problema de otimização combinatória, no qual encontrar um "bom" subconjunto de genes preditores de um outro, significa minimizar uma função custo no espaço completo de todos os subconjuntos dos genes que formam a rede. Esta função custo é uma medida estatística sobre distribuições conjuntas de probabilidade que permite caracterizar dependência (por exemplo: entropia). Esse é um problema exponencial no qual as heurísticas conhecidas atingem um resultado sub-ótimo. Com o objetivo de desenvolver uma nova solução para esse problema, apresentamos um novo algoritmo branchand-bound, denominado algoritmo U-curve, que executa uma busca completa sem percorrer o espaço total de possibilidades.

Dividiremos nosso trabalho nas seguintes partes:

- No Capítulo 2 apresentamos os conceitos empregados em nosso trabalho e como eles se encontram atualmente com suas bibliografias relevantes. Ele se compõe basicamente de: (i) uma introdução às redes genéticas; (ii) discussão dos experimentos de microarrays e 
séries-temporais; (iii) uma intodução aos sistemas dinâmicos, discutindo sobre o conceito de Redes Genéticas Probabilísticas e identificação de uma rede; e (iv) um resumo sobre o estrógeno.

- No Capítulo 3, nossa solução para o problema de otimização combinatória é apresentado em detalhes. Resultados comparativos entre o nosso método e os mais utilizados atualmente são abordados e discutidos.

- No Capítulo 4, apresentamos nosso método com base no pipeline de algoritmos desenvolvido. Uma aplicação do método em dados de série-temporal de microarray resulta em uma rede genética representada por um grafo dirigido.

- No Capítulo 5, ao utilizar parte do pipeline, apresentado anteriormente, e partindo-se de genes regulados diretamente por estrógeno, pudemos evidenciar um novo marcador gênico para o estrógeno: a adesão celular. O processo utilizado, assim como a relevância deste resultado são, também, discutido ao final deste Capítulo.

- No Capítulo de conclusão, apontamos: (i) a contribuição deste trabalho em: Ciência da Computação e Estatística, Bioinformática e Biologia; (ii) um resumo dos resultados obtidos; e (iii) perspectivas de novas frentes de estudo que este trabalho oferece.

- No Apêndice A, descrevemos o programa que implementa o algoritmo U-curve com seus parâmetros e apresentamos uma parte do código implementado.

- No Apêndice B, apresentamos o banco de dados implementado e uma lista completa de genes-sementes para as iterações do pipeline.

- No Apêndice C, apresentamos a lista completa dos genes preditos pelo conjunto de genes regulados diretamente pelo estrógeno.

- No Apêndice D, listamos o conteúdo do DVD anexo.

- No Apêndice E, descrevemos os trabalhos apresentados e artigos submetidos e publicados.

\subsection{Objetivos}

Os principais objetivos deste trabalho podem ser enumerados a seguir:

- Definição do sub-sistema de genes afetados pelo estrógeno a partir de dados de expressão gênica;

- Obtenção da rede gênica para os genes do sub-sistema;

- Para cada gene do sub-sistema identificar o possível mecanismo transcricional que ele pertence;

- Encontrar novos possíveis genes afetados pelo estrógeno ainda não identificados. 
Modelar inter-relacionamentos entre genes nos remete a um problema de otimização combinatória, onde encontrar um "bom" subconjunto de genes preditores de um outro, significa minimizar uma função custo no espaço completo de todos os subconjuntos possíveis. Este é um problema exponencial no qual as heurísticas conhecidas atingem um resultado sub-ótimo. Um objetivo secundário deste trabalho é desenvolver uma nova solução para este problema. 
Introdução 


\section{Capítulo 2}

\section{Estado da arte}

\subsection{Sistemas dinâmicos}

Um sistema dinâmico é representado por um vetor de funções de transição que descreve a evolução temporal de um vetor denominado estado. As funções de transição podem, também, receber um sinal independente chamado de entrada. Em geral, não são os estados que são observados, e sim a transformação deles, a qual se dá por meio de um vetor de funções de transformação que resulta como resultado um vetor de saída. Para modelar uma rede de expressão gênica vamos utilizar sitemas dinâmicos finitos, discretos no tempo e finitos no número de estados. Um estado $x[t]$ em um instante $t$ é um vetor de dimensão $n$, onde cada elemento $x_{i}[t], i=1, . ., n$ representa a expressão do gene $i$ no instante $t$. A expressão pode ser discretizada por um conjunto $R$, por exemplo, $R=\{-1,0,1\}$, onde -1 indica sub-expressão, 0 expressão padrão, 1 super-expressão do gene, sendo assim, a função de transição $\phi$ é uma função de $R^{n}$ em $R^{n}$, e mapeia um estado $x[t]$ no próximo estado $x[t+1]$. Um sistema dinâmico finito (no número de estados), em cada instante $t$, é representado por:

$$
x[t+1]=\phi(x[t]),
$$

onde $x[t] \in R^{n}$, para todo $t \geq 0$.

Se a função de transição $\phi$ é a mesma para todos os instantes $t$, denominamos o sistema de translação-invariante no tempo.

\subsection{Redes genéticas}

Genes codificam proteínas, sendo que algumas delas, por sua vez, regulam outros genes. Esse processo nos remete às denominadas redes genéticas. Redes genéticas combinam regulações gênicas com interações protéicas e podem ser extremamente complexas, isto é, um enorme número de variáveis (genes e proteínas) e um pequeno número de amostras tornam o estudo de todo o sistema inviável e impraticável. Existem um série de estudos [21, 10] que tentam modelar as redes genéticas. Esses estudos são baseados na análise da região promotora do gene por projetos de seqüenciamento ou no perfil de expressão do gene pela análise de dados de microarray 
ou de $S A G E$. O objetivo desses estudos é obter uma rede a partir dos dados de entrada indicando a maneira como a expressão de cada gene afeta a expressão de outros. Algumas redes podem indicar se um gene reprime ou ativa outros, enquanto outras indicam que a expressão de um gene em um certo período pode predizer a expressão de outro no período subseqüente. A Figura 2.1 mostra um exemplo de arquitetura de uma rede genética: os nós indicam os genes, as arestas dirigidas indicam que um gene ativa o outro, por exemplo, conectando o gene $A$ ao gene $B$, indica que $A$ ativa $B$, e as arestas bloqueadas indicam que um gene reprime o outro, por exemplo, conectando o gene $C$ ao gene $B$, indica que $C$ reprime $B$. A Figura 2.2 mostra um exemplo de uma rede genética, representando os preditores de um gene ao longo do tempo, isto é, a expressão de $B$ em um instante $(t+1)$ de tempo pode ser obtida pela expressão dos genes $A$ e $C$ no instante de tempo anterior $(t)$. Uma tabela de predição também pode ser estimada para as redes dependentes de tempo. As tabelas de predição normalmente não indicam se um gene reprime ou ativa outro. A razão disso se dá devido ao fato de que a expressão de um gene depende, freqüentemente, não apenas de um único gene mas da expressão conjunta de um subconjunto destes.

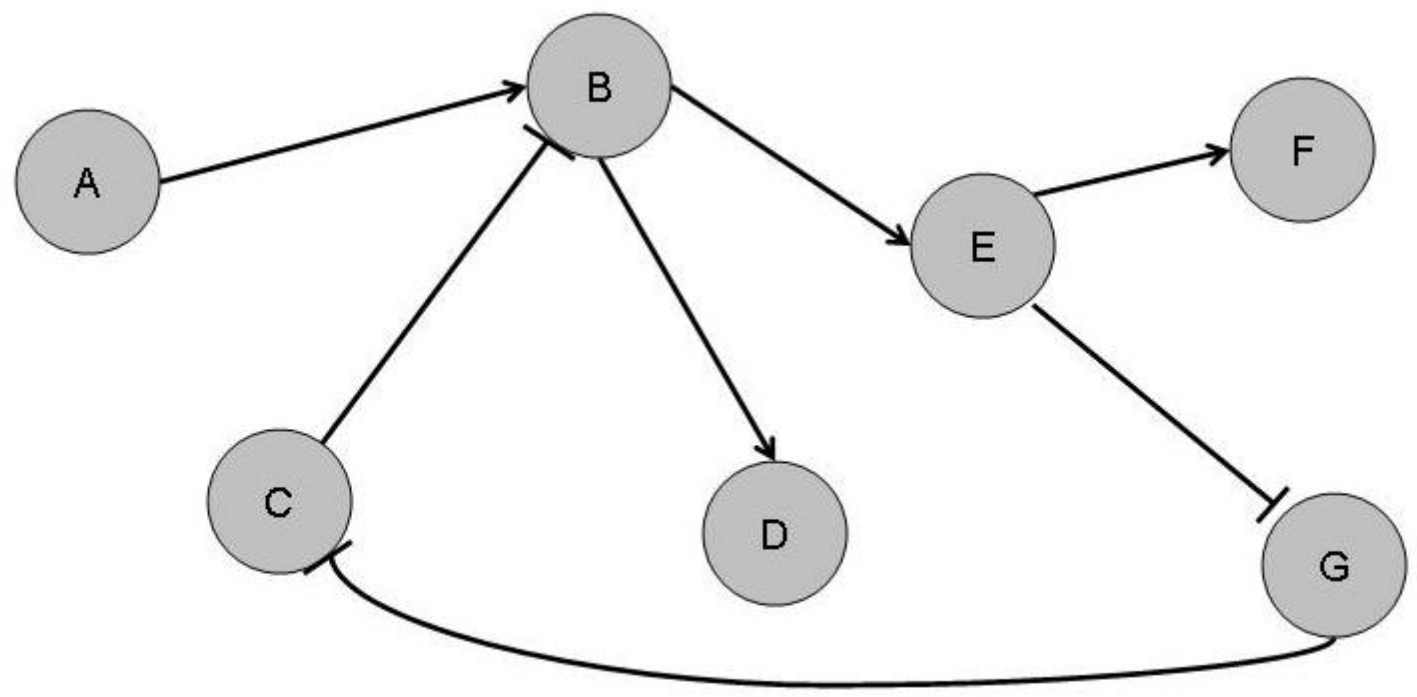

Figura 2.1: Um exemplo de arquitetura de uma rede genética composta por 7 genes

\subsection{Rede genética probabilística}

Podemos dizer que um sistema dinâmico é um processo estocástico quando a função de transição $\phi$ é uma função estocástica, isto é, o próximo estado $\phi(x[t])$ é a realização de um vetor aleatório $X_{t}$. Considere a seqüência de vetores aleatórios $X_{0}, X_{1}, X_{2}, \ldots$ assumindo valores $x[0], x[1], x[2]$ em $R^{n}$. 


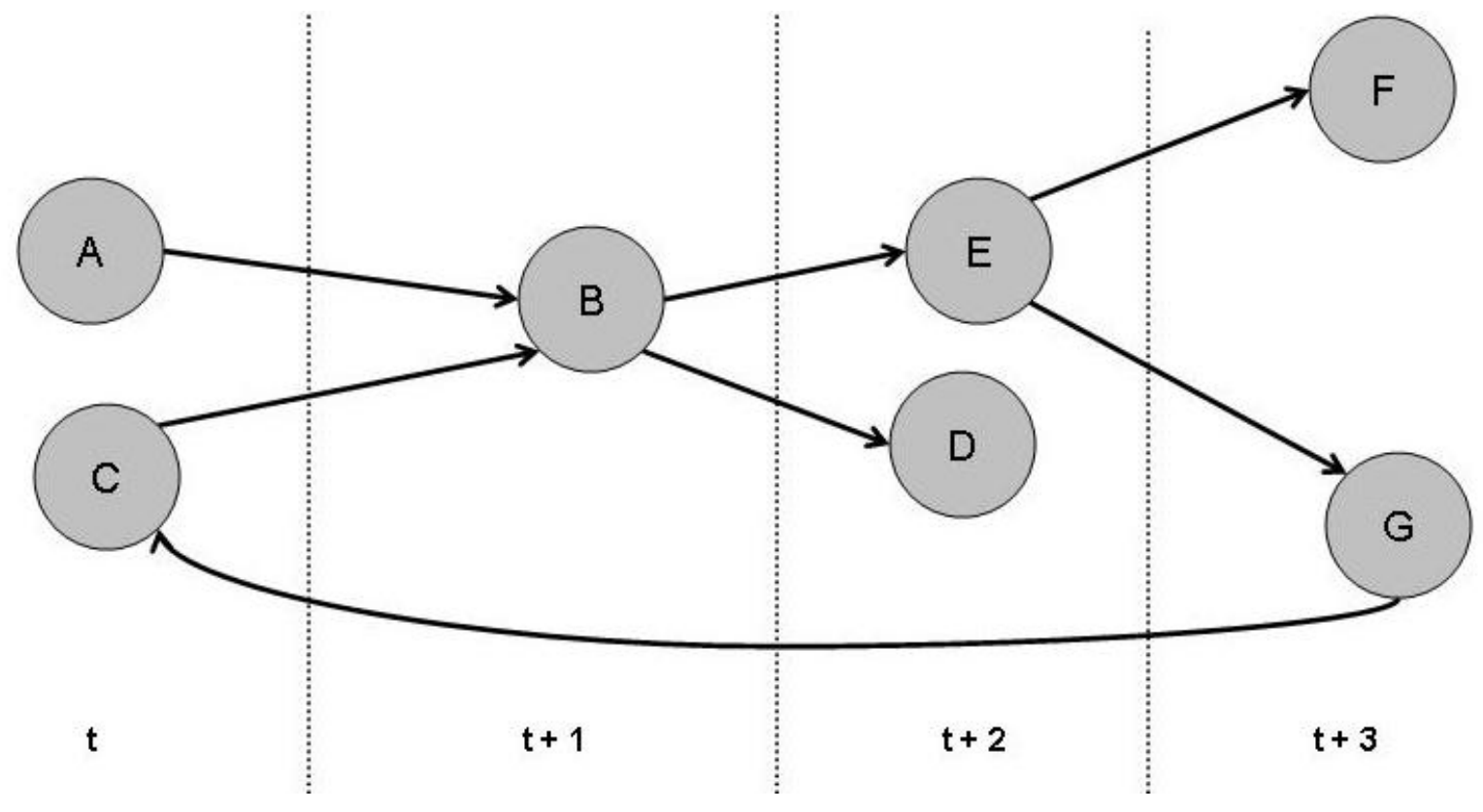

Figura 2.2: Um exemplo de uma rede genética de 7 genes para 4 períodos de tempo

Uma cadeia de Markov, de primeira ordem, é definida por uma seqüência de estados aleatórios $\left(X_{t}\right)_{t=0}^{\infty}$, se para cada instante $t \geq 1$,

$$
P\left(X_{t}=x[t] \mid X_{0}=x[0], \ldots, X_{t-1}=x[t-1]\right)=P\left(X_{t}=x[t] \mid X_{t-1}=x[t-1]\right),
$$

ou seja, a probabilidade de um evento futuro depende apenas do último evento, e não de todos os eventos passados. Cadeias de Markov podem ser caracterizadas por uma matriz de transição $\pi_{Y \mid X}$ de probabilidades condicionais entre estados, em que cada elemento representa a probabilidade condicional $p_{y \mid x}$, onde $x$ e $y$ são dois estados da cadeia, e uma condição inicial de estados $\pi_{0}$. Com isso, a função de transição estocástica $\phi$ no instante $t \geq 1$ é dada por:

$$
\phi(x[t])=y,
$$

onde $y$ é a realização de um vetor aleatório com distribuição de probabilidades $p_{\bullet} \mid x[t]$.

Rede Booleana Probabilística (PBN) [36, 37] é uma extensão de Redes Booleanas [23], nas quais a função Booleana para determinar o próximo estado na rede é não-determinística e pode variar de acordo com uma função probabilística, isto é, uma função Booleana é sorteada a partir de uma distribuição de probabilidades e usada para determinar o próximo estado da rede. Em certos casos é desejável trabalhar não somente com valores Booleanos mas com valores discretizados em múltiplos níveis, por exemplo, $x_{i}[t] \in\{-1,0,1\}$ para expressões gênicas com: -1, indicando sub-expressão; 0, expressão normal (igual a um valor de referência); ou 1, superexpressão, e, nesses casos, a teoria deve ser extendida [44].

Rede Genética Probabilística ( $P G N$ ) [3] é um modelo usado para representar redes genéticas. Ela é derivadas da Rede Booleana Probabilística $(P B N)$, nas quais a função de transição não é determinística e os estados são compostos por valores discretos. Em outras palavras, $P G N$ é uma 
cadeia de Markov $\left(\pi_{Y \mid X}, \pi_{0}\right)$, na qual cada estado é um vetor de expressões gênicas discretizadas por alguns axiomas:

- a função de transição é independente do tempo ( $\pi_{Y \mid X}$ é homogêneo): a probabilidade de um estado dado um estado anterior não varia no tempo $\left(p_{y \mid x}\right.$ é independente de $\left.t\right)$;

- todas as probabilidades de transição possuem um valor positivo maior que $0\left(p_{y \mid x}>\right.$ $\left.0, \forall x, y \in R^{n}\right)$ : todos os estados, dado um estado anterior, tem probabilidade de ocorrer;

- a função de transição $\left(\pi_{Y \mid X}\right)$ é condicionalmente independente: a probabilidade de um estado é dada pelo produto das probabilidades de suas componentes dado um estado anterior $\left(\forall x, y \in R^{n}, p_{y \mid x}=\prod_{i=1}^{n} p\left(y_{i} \mid x\right)\right)$;

- a função de transição $\left(\pi_{Y \mid X}\right)$ é quase-deterministica: existe um estado com probabilidade muito maior de ocorrer do que os outros $\left(\forall x \in R^{n}, \exists i \in\{1, \ldots, n\}\right.$, tal que, $\left.\mid p_{y_{i} \mid x} \approx 1\right)$;

- existe um subconjunto "pequeno" das componentes do estado que, quando a função de transição é restrita a ele, possui resultados iguais à função de transição aplicada ao estado completo. Em outras palavras, o próximo estado pode ser determinado por um "pequeno" subconjunto dos componentes do estado anterior, isto é: $\forall x \in R^{n}, \forall i \in\{1, \ldots, n\}$, existe um sub-espaço de dimensão $j, j<<n$, tal que: $p_{y_{i} \mid x^{\prime}} \approx p_{y_{i} \mid x}$, onde $x^{\prime}$ é a projeção de $x$ neste sub-espaço.

Esses axiomas são motivados pela comum falta de dados e enorme número de variáveis em experimentos biológicos, isto é, existem poucas amostras de microarray para milhares de genes em um experimento série-temporal microarray, e implicam que cada gene pode ser caracterizado por um vetor de coeficientes $a$ e um vetor de funções estocáticas $g_{j}$ que leva um número inteiro em $\mathbb{Z}$ a um elemento de $R$. O vetor $a^{j}$ indica os genes que afetam o gene $j$, isto é, se $a_{i}^{j}>0$, o gene $i$ excita o gene $j$ (regulação positiva), se $a_{i}^{j}<0$, o gene $i$ inibe o gene $j$ (regulação negativa), se $a_{i}^{j}=0$, o gene $i$ não afeta o gene $j$. Logo, o gene $j$ é previsto apenas pelos genes $i$ que possuem $a_{i}^{j} \neq 0$. Podemos assim decompor a função de transição estocástica $\phi$ em componentes $\phi_{j}$ que são obtidos pela composição da função estocástica $g_{j}$ aplicada a combinação linear de $a^{j}$ e o estado anterior $x[t]$, isto é, para todo instante $t \geq 1$ :

$$
\phi_{j}(x[t])=g_{j}\left(\sum_{i=1}^{n} a_{i}^{j} x_{i}[t]\right),
$$

onde $g_{j}\left(\sum_{i=1}^{n} a_{i}^{j} x_{i}[t]\right)$ é a realização de uma variável aleatória em $R$ com distribuição $p_{\bullet} \mid \sum_{i=1}^{n} a_{i}^{j} x_{i}[t]$.

\subsection{Identificação do sistema}

Nesta seção estudaremos um método para a identificação da PGN (Rede Genética Probabilística) e, para isso, iremos introduzir alguns conceitos estatísticos necessários. Os conceitos definidos a seguir são aplicados a variáveis aleatórias discretas, as quais podem assumir valores discretos no conjunto $R=\{1,2, \ldots, n\}$ : 
A Entropia $H(X)$ de uma variável aleatória $X$ é uma medida aplicada à distribuição $p_{X}$, dada por:

$$
H(X)=\sum_{i=1}^{n} p_{i} \log p_{i}
$$

onde $p_{i}=P(X=i), i \in R$. A entropia é uma função aplicada a distribuição de probabilidades que possui algumas importantes características:

1. qualquer distribuição $p_{X^{\prime}}$ formada por uma permutação da distribuição $p_{X}$ possui mesmo valor de entropia;

2. quanto maior a concentração de probabilidade em algum valor, isso implica em um menor valor de entropia. Podemos dizer, com isso, que a entropia mede o grau de aleatoriedade da variável $X$. Pode-se provar que a máxima entropia é atingida na distribuição uniforme, e a mínima é atingida quando a probabilidade está toda concentrada em apenas um valor[1].

A Informação Mútua $I(X, Y)$ entre duas variáveis aleatórias $X$ e $Y$, é obtida por:

$$
I(X, Y)=H(Y)-H(Y \mid X),
$$

onde $I(X, Y) \geq 0$. Essa medida aufere o grau de independência entre $X$ e $Y$ valendo 0 se e somente se $X$ e $Y$ são independentes. A entropia condicional $H(Y \mid X)$ mede a concentração de massa de $p_{Y}$ em $p_{Y \mid X}$, ou seja, quanto maior a concentração de massa, menor seu valor, atingindo seu pico em $H(Y)$; já a informação mútua descreve caminho inverso, quanto maior a concentração de massa, maior seu valor.

Como vimos na seção anterior, a hipótese quase-determinística assumida para a PGN e a hipótese de que um subconjunto pequeno de genes é necessário para a previsão de um gene-alvo nos remete a um valor alto para a esperança da informação mútua deste em relação ao subconjunto de genes. Com isso, o problema de identificação da PGN (encontrar tais subconjuntos de genes preditores para cada gene-alvo) pode ser interpretado como um problema de maximização da esperança da informação mútua $E[I(X, Y)]$, dada por:

$$
E[I(X, Y)]=H(Y)-E[H(Y \mid X)]
$$

onde a variável aleatória $Y$ representa a expressão $y_{j}[t+1]$ do gene $j$ no instante $t+1$, e a variável $\mathrm{X}$ representa o vetor de variáveis aleatórias $X_{i}$, que é a ponderação da expressão do gene $i$ no instante $t$ pela componente $a_{i}$ do vetor de coeficiente inteiro $a$, visto na seção anterior. No nosso caso, assumiremos que $a_{i} \in\{0,1\}$ valendo 1 se o gene $i$ afeta (positivamente ou negativamente) o gene $j$, e 0 caso contrário. O problema então se transforma em um outo: encontrar qual vetor $a$ (ou vetores $a$ 's) maximiza (maximizam) a informação mútua, ou de modo análogo minimiza (minimizam) a entropia condicional média. Aplicando o método para cada gene $j$ podemos construir a rede de conexão entre os $n$ genes estudados, onde cada gene $j$ pode ser predito pelos genes que se ligam a ele, segundo a estimação da distribuição de probabilidade $p_{y_{j} \mid a}$, obtida 
sempre dos dados amostrais. Esse problema pode ser interpretado na área de Reconhecimento de Padrões [9] como um problema de seleção de características, onde estamos interessados em selecionar os genes (características) que melhor predizem um outro gene (classe), segundo uma função critério que para nosso caso será a minimização da entropia condicional média estimada. Para a estimação da entropia condicional média, podem ser usados vários métodos, sendo o empregado em nossos experimentos a estimação utilizada por Barrera et al. [3].

\subsection{O problema de seleção de características}

Um algoritmo de otimização combinatória seleciona, a partir de uma coleção finita de objetos (chamada de espaço de busca), aquele objeto que possui custo mínimo de acordo com uma dada função custo. A arquitetura mais simples para esse algoritmo, chamada de busca completa, percorre todos os objetos do espaço de busca, porém, é impraticável para espaços de busca de tamanho grande. Para esses casos, é possível percorrer alguns objetos e escolher o de mínimo custo, baseando-se nas medidas observadas. Algoritmos baseados em heurísticas e branch-andbound são dois tipos de soluções para este problema. Os algoritmos baseados em heurísticas não possuem garantia formal em encontrar o objeto de custo mínimo, enquanto os branch-and-bound possuem propriedades matemáticas que garantem encontrá-lo.

O problema aqui estudado é um problema de otimização combinatória onde o espaço de busca é composto por $2^{n}$ objetos, organizados como um reticulado Booleano, e a função custo possui um formato de curva em U para qualquer cadeia maximal do espaço de busca.

Esse tipo de estrutura é encontrado em alguns problemas conhecidos, tais como: seleção de características em Reconhecimento de Padrões [9, 19] e projeto de $W$-operadores em morfologia matemática [22]. Nesses problemas, um subconjunto mínimo de características, que é suficiente para representar um objeto, deve ser obtido de um conjunto de $n$ características. No projeto de $\mathrm{W}$-operadores, as características são pontos de um retângulo em $Z^{2}$ chamado de janela. As funções com formato de curva em U são formadas pelo erro de estimação dos classificadores ou W-operadores projetados. Esse é um fenômeno muito conhecido na área de Reconhecimento de Padrões: para um conjunto de treinamento fixado, o aumento no número de características consideradas para a construção do classificador implica na redução do erro de classificador, pelo aumento na separação entre as classes. Isso ocorre até que os dados disponíveis se tornam insuficientes para cobrir o domínio do classificador, e o aumento do erro de estimação implica em aumento do erro do classificador. Os métodos conhecidos para esse problema são na sua maioria heurísticas, sendo o SFS e o SFFS [32] dois casos de relativos sucessos.

Existe uma gama de algoritmos branch-and-bound na literatura e a maioria deles são baseados na premissa de monotonicidade da função custo [12, 27, 40, 43]. No trabalho em [39] temos um resumo da literatura existente de algoritmos branch-and-bound. Se a real distribuição das probabilidades conjuntas entre os padrões e classes são conhecidas, dimensionalidades maiores implicam em menores erros de classificação. Na prática, porém, essas distribuições não são conhecidas e devem ser estimadas. O problema na premissa de monotonicidade da função custo se dá, devido ao fato de que ela não considera o erro de estimação implícito para espaços de dimensões grandes ("curse of dimensionality", também conhecido como "problema U-curve" ou "fenômeno peaking" [19]). 


\subsection{O estrógeno}

O estrógeno não é apenas um hormônio, mas, sim, um grupo de hormônios que pode ser encontrado principlamente em três principais formas no corpo humano: estrona (E1), estradiol (E2) e estriol(E3), sendo a forma $17-\beta$ estradiol a mais abundante no corpo humano. O estrógeno possui um papel muito importante nos tecidos reprodutivos [45]: o crescimento das glândulas mamárias [14] e do endométrio durante a gravidez e o ciclo menstrual são estrógenodependentes. Os efeitos biológicos dos estrógenos são mediados por meio de seu receptor (ER) $\alpha$ e $\beta$. Esses receptores são membros de uma super-família de receptores nucleares e agem como um fator de transcrição quando ativados pela molécula ligante. Os receptores de estrógeno podem influenciar a expressão gênica por meio de quatro vias clássicas conhecidas [28, 4]:

1. via clássica (nuclear): dímero E2-ER se liga ao elemento de resposta na região promotora dos genes;

2. via independente de elemento de resposta: o dímero E2-ER se liga por uma conexão proteína-proteína a um fator de transcrição que, por sua vez, se liga na região promotora do gene.

3. via independente de estrógeno: fatores de crescimento $(G F)$ ativam via de proteína-kinase, a qual fosforila e ativa os receptores de estrógeno quando ligados aos seus elementos de resposta.

4. via não-genômica: o dímero E2-ER ativa via de proteína-kinase, a qual pode alterar funções de proteínas no citoplasma ou fosforilar e ativar fatores de transcrição.

A Figura 2.3 mostra uma representação esquemática das quatro vias descritas.

É importante notar que os receptores de estrógeno contêm duas funções de ativação(FA) transcricional independentes: uma autônoma, presente na porção $N$-terminal, e outra dependente de ligantes. Assim, a atividade dos ERs pode ser controlada por várias outras proteínas. Essa ativação de ERs dependente de ligantes necessita de co-ativadores como TIF2 e SRC-1. A ativação transcricional dos ERs também é regulada por fosforilação, seja pela MAPK na presença de fatores de crescimento ou pela $C d k^{7} 7$ na forma dependente de ligantes.

Existem dois tipos de receptores de estrógeno $\operatorname{ER} \alpha$ e $\operatorname{ER} \beta$ concentrados e localizados em diferentes partes do organismo, e ambos podem se ligar ao estrógeno ou a outras moléculas como vimos, tornando o complexo ativo ou inativo. A Figura 2.4 mostra a estrutura tridimensional dos receptores de estrógeno, quando ativados (ligados ao estrógeno) ou desativados (ligados a uma molécula antagonista).

O estrógeno exibe um papel biológico importante nos tecidos dos órgãos reprodutores. O crescimento da glândula mamária como também do endométrio durante a gravidez e durante o ciclo menstrual são dependentes de estrógeno. Em adição aos efeitos proliferativos normais do estrógeno, temos os efeitos estimulantes para iniciação e promoção de tumores nestes mesmos órgãos. O crescimento estimulado pelo estrógeno nas células tumorais, assim como, nas normais requer a presença de receptores de estrógeno. A expressão dos receptores de estrógeno em uma célula tumoral pode classificar o tumor em dois sub-grupos: os tumores $E R+$ (ou ER positivos) 


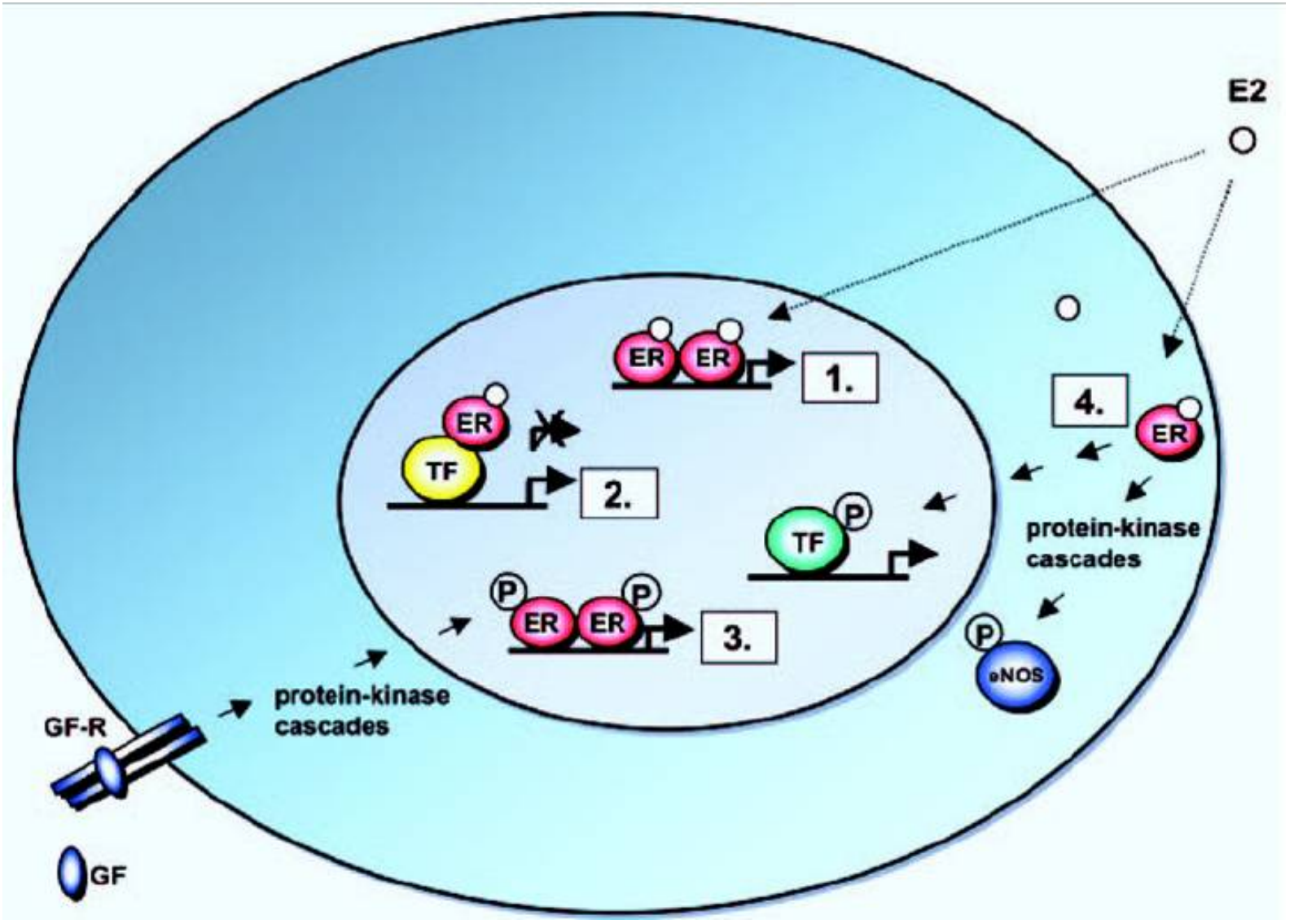

Figura 2.3: Representação esquemática das 4 vias clássicas de ação dos receptores de estrógeno (Extraído do trabalho em [4])

e os tumores ER- (ou ER negativos). Sabe-se que os tumores ER-são mais agressivos e possuem pouco sucesso nos tratamentos conhecidos até o momento. Nas clínicas médicas são usadas terapias tanto com drogas anti-estrogênicas como com drogas inibidoras de aromatases. Espera-se que o Tamoxifen, uma droga anti-estrogênica, se ligue ao ER tornando-o não funcional, enquanto que os inibidores de aromatase reduzem os níveis de estrógeno. A maioria dos tumores $E R+$ responde ao tratamento com Tamoxifen, no entanto uma grande parcela destes pacientes com o tempo adquire resistência ao tratamento além de não suportarem o tratamento pelos efeitos colaterais das drogas. Os pacientes ER negativos, por não apresentarem o receptor de estrógeno, usualmente não respondem a terapia anti-estrogênica.

Existem mais de 300 genes conhecidos regulados positivamente ou negativamente pelo estrógeno, segundo esta via direta ou usando outras indiretas. Entre os genes regulados positivamente, podemos citar: IGFBP 4 (Insulin-like growth factor binding protein 4), GREB1, PGR (Progesterone receptor); e os negativamente: NMA (Putative transmembrane protein), BMP7 (Bone morphogenetic protein 7). Os estudos, atualmente, estão direcionados de modo a caracterizar o melhor possível a via metabólica do estrógeno, ou seja: 


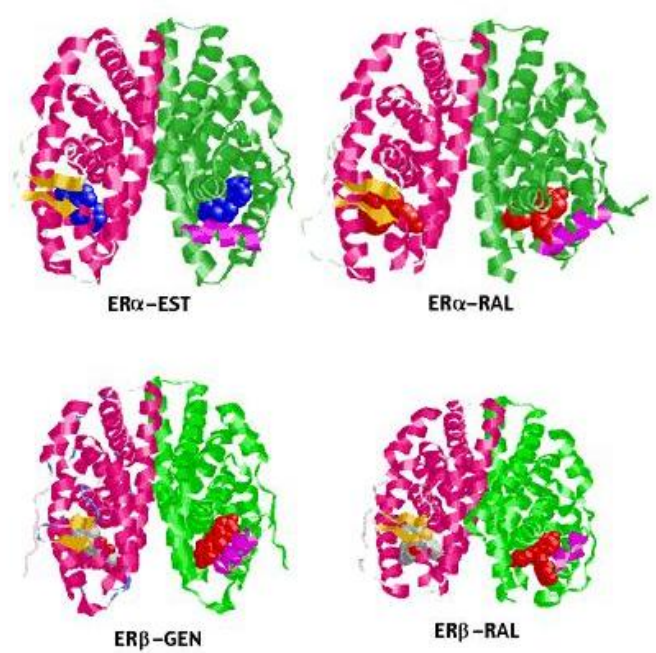

Figura 2.4: Representação tridimensional dos receptores de estrógeno (ER $\alpha$ e $\operatorname{ER} \beta$ ). Ligados ao estrógeno: ER $\alpha$-EST (Estradiol) ou ER $\beta$-GEN (Genisteína); e ao Raloxifene (antagonista de estrógeno): $\mathrm{ER} \alpha-\mathrm{RAL}$ ou $\mathrm{ER} \beta$-RAL

- identificação dos genes regulados positivamente ou negativamente pelo estrógeno;

- identificação de vias alternativas ao estrógeno, bem como novos fatores de transcrição alternativos aos receptores de estrógeno, e, assim, explicar a regulação nos tumores ER-;

- identificação da rede de expressão gênica, que caracteriza a inter-regulação entre os genes encontrados.

Existem vários estudos feitos na identificação dos genes regulados pelo estrógeno, entre eles, podemos citar:

- V. X. Jin et al. [20] utilizam uma nova técnica denominada ChIP-on-chip para a identificação de seqüência promotora relativa ao receptor $\mathrm{ER} \alpha ; 70$ genes candidatos foram obtidos;

- B. S. Katzenellenbogen et al. [13] obtêm 438 genes regulados, dos quais $70 \%$ são reprimidos pelo estrógeno, a partir de dados de microarray em células $M C F-7$ (células de tumor de mama $E R+)$;

- E. T. Liu et al. [26] obtêm uma lista de 386 genes responsivos ao estrógeno, dos quais 137 são regulados pelo estrógeno e 89 diretamente regulados (59 positivamente e 30 negativamente), a partir de experimentos de série-temporal de microarray em céluas $T 4 \%$ - $D$ (células de tumor de mama $E R+$ - expressam ER em maior quantidade que as células MCF-7) submetidas ao estrógeno e componentes anti-estrógeno e inibidor de síntese protéica; 
- A. Weisz et al. [41] identificam um conjunto de 61 genes que caracterizam células $\mathrm{ER} \alpha$ positivas, a partir de dados de microarray em culturas celulares $M C F-7$ e ZR-75.1 (células de tumor de mama ER-positivas) induzidas por estrógeno;

- K. R. Coser et al. [7] estudam a sensitividade dos genes em resposta ao estrógeno, por meio de análise de microarray em cultura celular $M C F-7$ induzidas por diferentes níveis de concentração de estrógeno, e o resultado obtido sugere diferenças em sensitividade entre os genes responsivos ao estrógeno;

- A. S. Levenson [25] procuram identificar genes regulados por estrógeno por meio de análise de microarray em cultura celular MCF-7 induzida por diferentes complexos entre ER $\alpha$ e seus diversos ligantes, tais como: estrógeno, raloxifene e tamoxifene.

Os genes responsivos ao estrógeno podem ser agrupados em razão de suas funções biológicas. Podemos citar dois métodos de padronização das funções biológicas do genes: (i) o Gene Ontology Consortium [2] que relaciona o gene com processos biológicos de qualquer organismo; (ii) o banco de dados KEGG [29], que associa um gene a uma via de regulação. Genes que apresentam funções biológicas associadas à proliferação celular podem ser relacionados ao câncer [42] e o estrógeno, por sua vez, regula positivamente ou negativamente esses genes [13]. Entre as funções biológicas relacionadas à proliferação celular dos genes regulados pelo estrógeno temos: ciclo celular, apoptose, fatores de crescimento, citoquinas, hormônios, receptores, transdução de sinais, fatores de transcrição, fatores de crescimento.

\subsection{Microarrays}

A tecnologia de microarray [34] permite estudos baseados em larga escala de dados, tais como genômica funcional e sistemas biológicos, pela medição de níveis de expressão de milhares de genes simultaneamente. Os dados resultantes são a base para uma gama de estudos de perfis moleculares e para o entendimento dos mecanismos biológicos e de regulação para um organismo específico ou uma cultura celular [35]. Esses estudos podem ser executados a partir de um único experimento, resultando no agrupamento (clustering) de genes que possuem sinais de expressões semelhantes. Quando os estudos necessitam dos perfis de expressão em um período de tempo, em vez de um único intervalo, o experimento de série-temporal de microarray (time-course microarray) é utilizado. A análise dos dados de expressão dessa técnica pode agrupar os genes com perfis de expressão temporal semelhantes [31], mas, também, podem ser a base para a construção de uma rede genética [17]. A Figura 2.5 mostra uma representação esquemática de um experimento de série-temporal de microarray: $n$ genes em $m$ períodos de tempo e cada vetor $x[i]$ representa o experimento de microarray no instante $i$. 


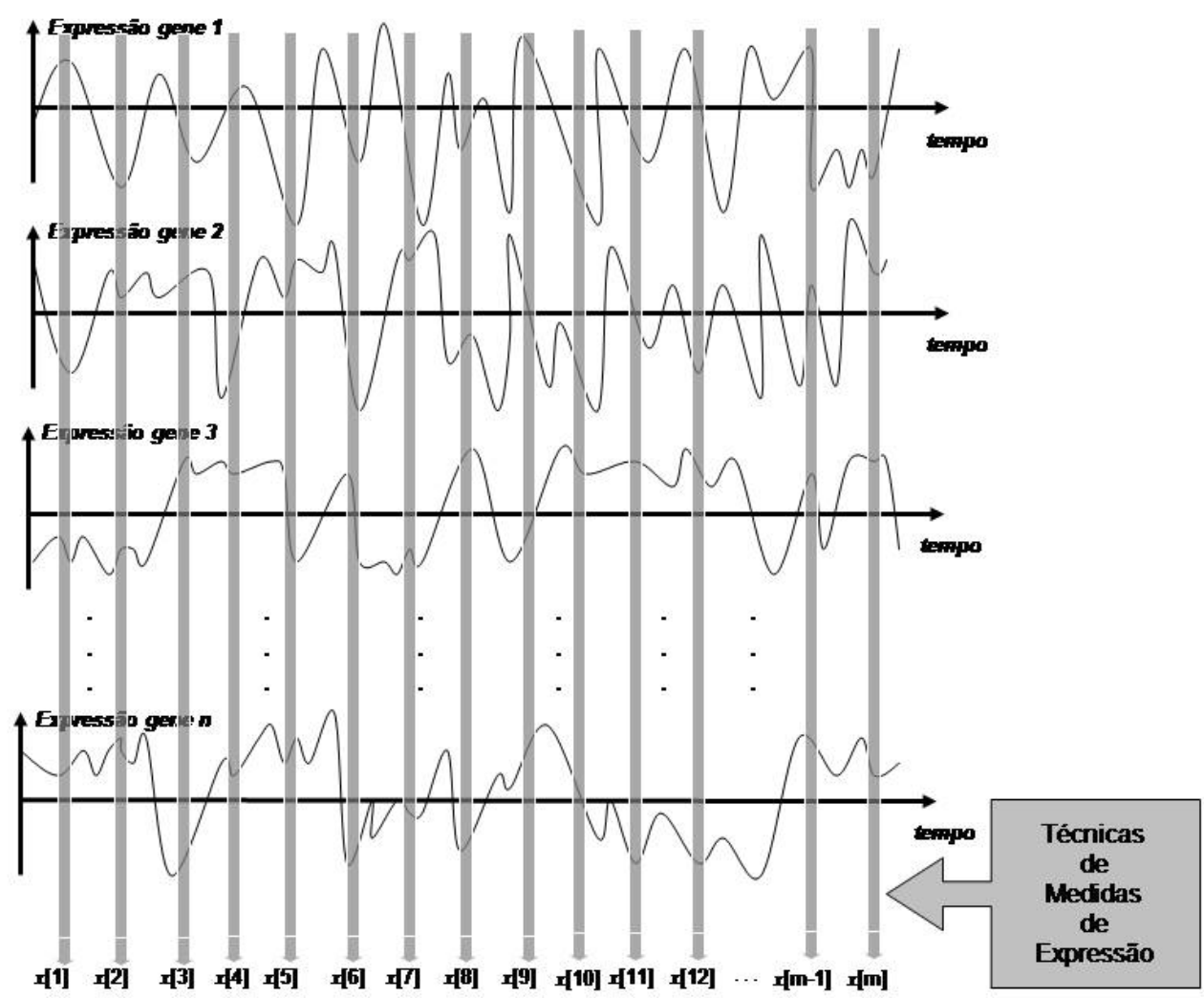

Figura 2.5: Representação esquemática de um experimento de série-temporal de microarray 


\section{Capítulo 3}

\section{O algoritmo U-curve}

Neste Capítulo apresentaremos um probema de otimização combinatória com as seguintes características:

i. o espaço de busca é composto por $2^{n}$ objetos organizados como um reticulado Booleano;

ii. a função custo descreve uma curva em $U$ quando aplicada a todos os elementos de qualquer cadeia maximal do reticulado.

Essa formulação pode ser caracterizada por um problema de seleção de características no contexto de Reconhecimento de Padrões. Os estudos conhecidos para esse problema recaem em heurísticas que exploram o espaço de maneira parcial, não sendo equivalente a busca completa ou outros algoritmos branch-and-bound que dependem da monotonicidade da função custo para atingirem a solução ótima com um tempo computacional bem menor que o obtido pela busca exaustiva.

Apresentamos uma solução branch-and-bound, a qual usa a estrutura do reticulado Booleano e as curvas em U da função custo para explorar um subconjunto do espaço de busca equivalente à busca completa. Algumas aplicações no projeto de $W$-operadores e na identificação da arquitetura de redes gnéticas ilustam os resultados aqui apresentados. Novas propriedades sobre reticulados Booleanos foram descobertas e aplicadas no desenvolvimento de uma estrutura de dados adequada, para representar e atualizar a parte não explorada do espaço de busca.

Seguindo esta Introdução, a Seção 3.1 apresenta a formalização do problema estudado. A Seção 3.2 descreve o algoritmo branch-and-bound de maneira estrutural. A Seção 3.3 apresenta as propriedades matemáticas que dão suporte aos passos do algoritmo. A seção 3.4 apresenta algumas aplicações do algoritmo para o projeto de $\mathrm{W}$-operadores e para a identificação da arquitetura de redes genéticas. Finalmente, a Seção 3.5 discute as contribuições desta solução e propões algumas próximas etapas possíveis desta pesquisa. 


\subsection{Otimização de curvas em U}

O espaço de busca é composto por $2^{n}$ objetos, organizados em um reticulado Booleano. Seja $W$ um subcojunto finito, $\mathscr{P}(W)$ a coleção de todos os subconjuntos de $W, \subseteq$ a relação usual de inclusão sobre conjuntos e $|W|$ denotando a cardinalidade de $W$.

O conjunto parcialmente ordenado (poset) $(\mathscr{P}(W), \subseteq)$ é um reticulado Booleano completo $\mathcal{L}$ de grau $|W|$ onde: o menor e o maior elemento são, respectivamente, $\emptyset$ e $W$; a soma e o produto são, respectivamente, a união e intersecção usuais sobre conjuntos e o complemento de um conjunto $X$ em $\mathscr{P}(W)$ é o seu complemento em relação a $W$, denotado por $X^{c}$.

Subconjuntos de $W$ serão representados por cadeias de 0's e 1's, com 0 indicando que o ponto não pertence ao subconjunto e 1 indicando que ele pertence. Por exemplo, se $W=$ $\{(-1,0),(0,0),(+1,0)\}$, o subconjunto $\{(-1,0),(0,0)\}$ será representado por 110. Como abuso de linguagem, ocorrências de $X=110$, por exemplo, indica que $X$ é o conjunto representado por 110 .

Uma cadeia em $\mathcal{X} \subseteq \mathscr{P}(W)$ é uma coleção $\mathcal{A}=\left\{A_{1}, A_{2}, \ldots, A_{k}\right\} \subseteq \mathcal{X}$, tal que, $A_{1} \subseteq A_{2} \subseteq$ $\ldots \subseteq A_{k}$. Uma cadeia $\mathcal{M} \subseteq \mathcal{X}$ é maximal em $\mathcal{X}$ se não existe outra cadeia $\mathcal{C} \subseteq \mathcal{X}$ tal que $\mathcal{C}$ contêm propriamente $\mathcal{M}$.

Seja $c$ uma função custo definida de $\mathscr{P}(W)$ em $\mathbb{R}$, dizemos que $c$ é decomponível em curvas em $U$ se, para qualquer cadeia maximal $\mathcal{M} \subseteq \mathscr{P}(W)$, a restrição de $c$ em $\mathcal{M}$ descreve uma curva em $\mathrm{U}$, isto é, para qualquer $A, X, B \in \mathcal{M}, A \subseteq X \subseteq B \Rightarrow \max (c(A), c(B)) \geq c(X)$.

A Figura 3.1 aprsenta um reticulado Booleano completo $\mathcal{L}$ de grau 4 e uma fução de custo $c$ decomponível em curvas em U. Nessa figura, uma cadeia maximal com sua função custo em $\mathcal{L}$ é enfatizada. A Figura 3.2 apresenta as curvas da mesma função custo restrita a algumas cadeias maximais em $\mathcal{L}$ e em $\mathcal{X} \subseteq \mathcal{L}$. Note a forma em $\mathrm{U}$ das curvas da Figura 3.2.

Nosso problema consiste em encontrar o elemento (ou elementos) de custo mínimo no reticulado Booleano de ordem $|W|$. A busca completa nesse espaço é um problema exponencial, pois o espaço é composto por $2^{|W|}$ elementos. Sendo assim, para valores moderadamente grandes de $|W|$, a busca completa se torna inviável.

\subsection{Descrição do método U-curve}

Buscar subconjutos de custo mínimo pelo espaço de busca completo é um problema combinatório muito custoso. O formato de curva em U da restrição da função custo para qualquer cadeia maximal é a premissa para a elaboração de um algoritmo branch-and-bound, denominado, aqui, de algoritmo $U$-curve, para lidar com esse tipo de problema. O algoritmo $U$-curve realiza a busca total sobre o reticulado Boolenao completo $\mathcal{L}$ com uma considerável redução no processamento computacional em relação à busca exaustiva.

Sejam $A$ e $B$ elementos do reticulado Booleano $\mathcal{L}$. Um intervalo $[A, B]$ de $\mathcal{L}$ é um subconjunto de $\mathcal{L}$ dado por $[A, B]=\{X \in \mathcal{L}: A \subseteq X \subseteq B\}$. Seja $R$ um elemento de $\mathcal{L}$. Neste trabalho, intervalos do tipo $[\emptyset, R]$ e $[R, W]$ são chamados, respectivamente, de constrição inferior e superior. A extremidade esquerda de uma restrição inferior e a extremidade direita de uma restrição 


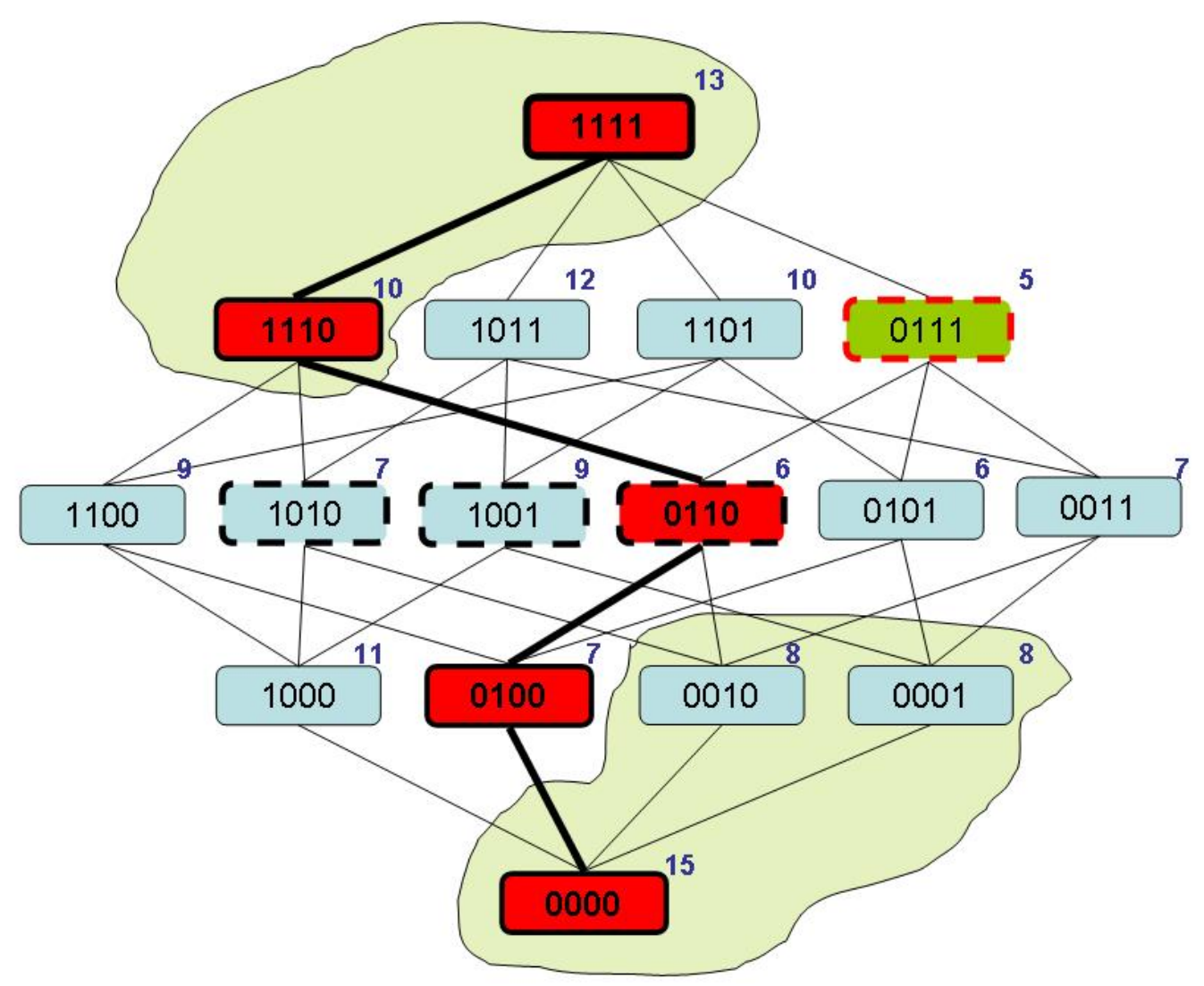

Figura 3.1: O espaço de busca em um reticulado Booleano de ordem 4. $\mathcal{X}$ é um poset obtido de $\mathcal{L}$, onde $\mathcal{X}=\mathcal{L}-\{0000,0010,0001,1110,1111\}$ 


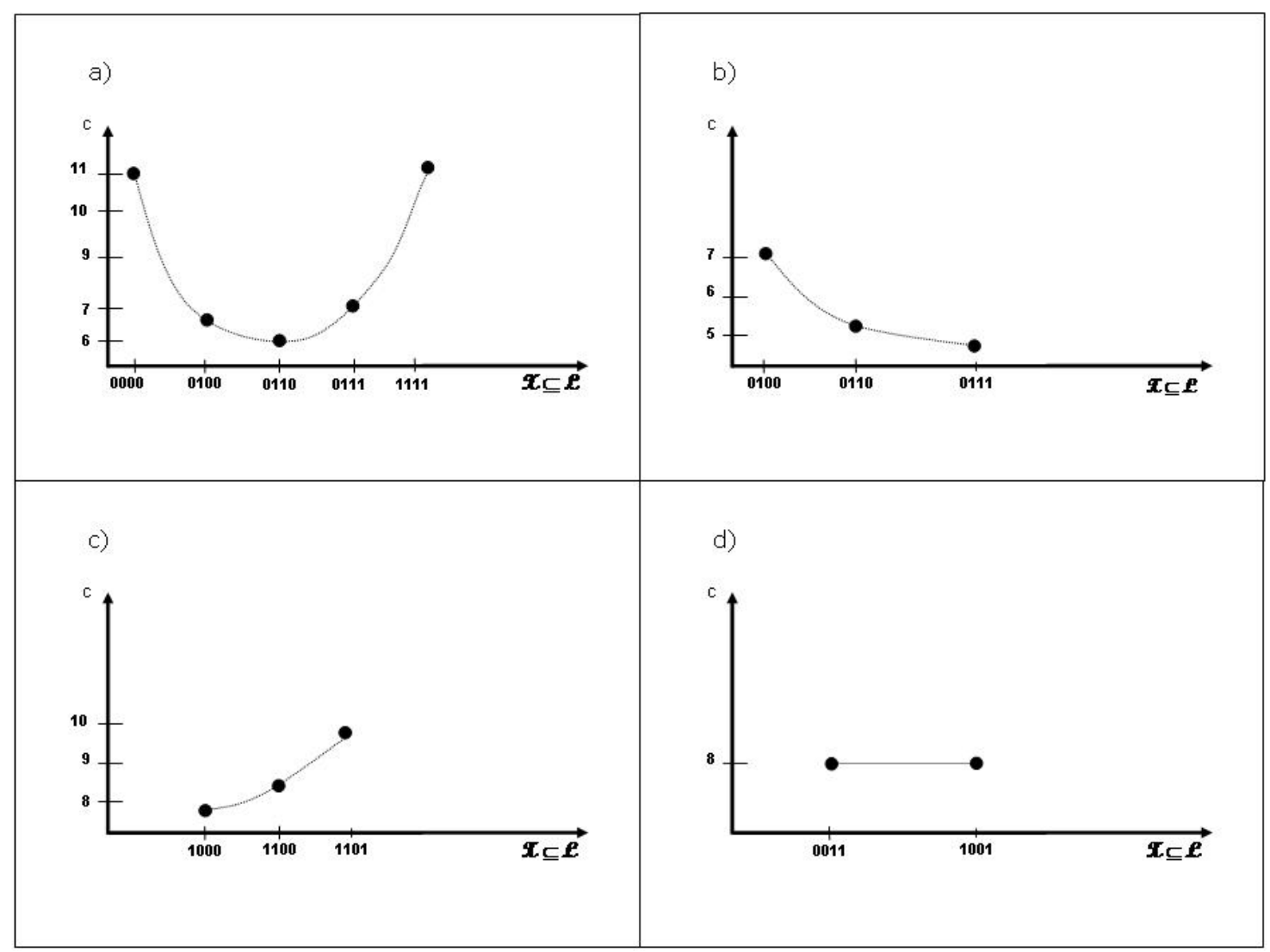

Figura 3.2: As quatro possíveis representações da função custo $c$ restritas a algumas cadeias maximais em $\mathcal{L}$ e em $\mathcal{X} \subseteq \mathcal{L}$ da Figura 3.1 
superior são chamadas, respectivamente, de restrição inferior e superior. Sejam $\mathcal{R}_{L}$ e $\mathcal{R}_{U}$ as representações, respectivamente, das coleções das restrições inferiores e superiores, o espaço de busca será o poset $\mathcal{X}\left(\mathcal{R}_{L}, \mathcal{R}_{U}\right)$ obtido eliminando-se a coleção de restrições inferiores e superiores do reticulado $\mathcal{L}$, isto é, $\mathcal{X}\left(\mathcal{R}_{L}, \mathcal{R}_{U}\right)=\mathcal{L}-\bigcup\left\{[\emptyset, R]: R \in \mathcal{R}_{L}\right\}-\bigcup\left\{[R, W]: R \in \mathcal{R}_{U}\right\}$. Em casos onde apenas as restrições inferiores ou superiores são eliminadas, o espaço resultante é denotado, respectivamente, por $\mathcal{X}\left(\mathcal{R}_{L}\right)$ e $\mathcal{X}\left(\mathcal{R}_{U}\right)$, e dado, respectivamente, por $\mathcal{X}\left(\mathcal{R}_{L}\right)=\mathcal{L}-\bigcup\{[\emptyset, R]$ : $\left.R \in \mathcal{R}_{L}\right\}$ e $\mathcal{X}\left(\mathcal{R}_{U}\right)=\mathcal{L}-\bigcup\left\{[R, W]: R \in \mathcal{R}_{U}\right\}$.

O espaço de busca é explorado por um algoritmo iterativo que, a cada iteração, explora um pequeno subconjunto de $\mathcal{X}\left(\mathcal{R}_{L}, \mathcal{R}_{U}\right)$, calcula um minimo local, atualiza a lista de elementos mínimos encontrados e extende ambos conjuntos de restrições, eliminando com isso a região recém explorada. O algoritmo é iniciado com uma lista vazia de elementos mínimos, assim como os conjunto de restrições inferiores e superiores. A execução do algoritmo é feita até que o espaço de busca seja totalmente explorado, isto é, até que $\mathcal{X}\left(\mathcal{R}_{L}, \mathcal{R}_{U}\right)$ fique vazio. O subconjunto de $\mathcal{X}\left(\mathcal{R}_{L}, \mathcal{R}_{U}\right)$ explorado a cada iteração é uma cadeia que pode ser contruída em sentido inferiorsuperior ou superior-inferior do reticulado. O algoritmo 1 descreve esse processo. O processo de seleção de direção (linha 5) é um procedimento que pode usar um método aleatório ou adaptativo. Para método randômico, uma probabilidade estática é definida para seleção de uma das direções possíveis. Já o método adaptativo calcula uma nova probabilidade a cada uma das direções, atribuindo maior valor para a direção inferior-superior ou superior-inferior se a maioria dos mínimos locais, encontrados até o momento, estão, respectivamente, mais perto da base ou do topo do reticulado.

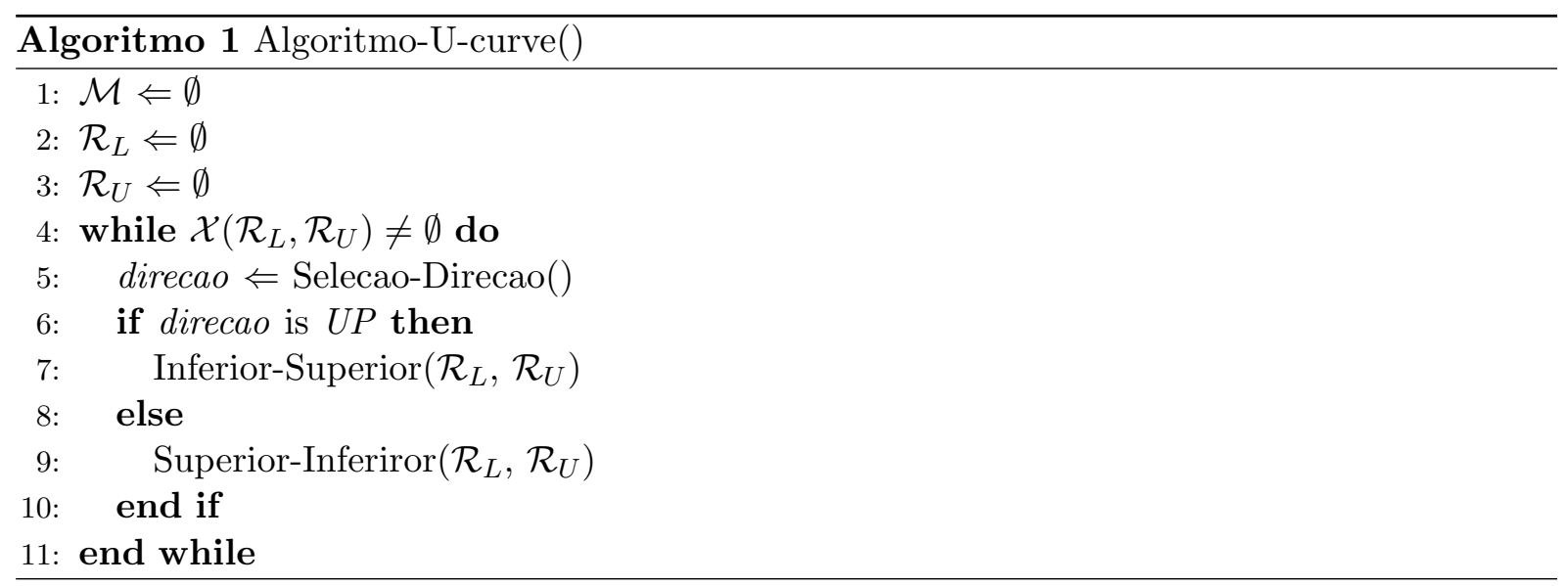

Um elemento $C$ do poset $\mathcal{X} \subseteq \mathcal{L}$ é chamado de elemento minimal de $\mathcal{X}$ se não existe outro elemento $C^{\prime}$ de $\mathcal{X}$ com $C^{\prime} \subset C$. Um elemento $D$ do poset $\mathcal{X} \subseteq \mathcal{L}$ é chamado de elemento maximal de $\mathcal{X}$ se não existe outro elemento $D^{\prime}$ de $\mathcal{X}$ com $D \subset D^{\prime}$. Na Figura 3.1, os elementos minimais de $\mathcal{X}\left(\mathcal{R}_{L}\right)$ são: 1000, 0100 e 0011, e os maximais são: 1011, 1101 e 0111. Se a direção inferior-superior é selecionada o processo Inferior-Superior é executado (Algoritmo 2):

- O procedimento Elemento-Minimal calcula um elemento minimal $B$ do poset $\mathcal{X}\left(\mathcal{R}_{L}\right)$. Somente o conjunto de restrições inferiores é utilizado para o cálculo desse elemento minimal. Um elemento $B$ é coberto pelo conjunto de restrições inferiores $\mathcal{R}_{L}$ se $\exists R \in \mathcal{R}_{L}: B \subseteq R$, e $B$ é coberto pelo conjunto de restrições superiores $\mathcal{R}_{U}$ se $\exists R \in \mathcal{R}_{L}: R \subseteq B$. Quando o elemento $B$ calculado é coberto por uma restrição superior este é descartado, isto é, 
o conjunto de restrições inferiores é atualizado $\operatorname{com} B$ e uma nova iteração do algoritmo pode ser iniciada (linhas 1-5).

- O processo de construção da cadeia na direção inferior-superior começa com um elemento minimal $B$ e adiciona novos elementos ao selecionar randomicamente um elemento na lista de elementos adjacentes superiores ao último adicionado e que pertencem ao poset atual $\mathcal{X}\left(\mathcal{R}_{L}, \mathcal{R}_{U}\right)$. Esse processo continua até que a condição $U$-curve seja encontrada, isto é, até que o último elemento a ser adicionado à cadeia $(B)$ tenha custo maior que o anterior (M) (linhas 7-11).

- Nesse ponto, o elemento $M$ é o elemento mínimo da cadeia construída e $A$ e $B$ são, respectivamente, os elementos adjacentes inferior e superior ao elemento $M$, isto é, $A \subset$ $M \subset B$ e, por construção, $c(A) \leq c(M) \leq C(B)$. Note que $A$ é equivalente ao conjunto vazio ou $B$ ao conjunto $W$, se $M$ não têm, respectivamente, elemento adjacente inferior ou superior em $\mathcal{X}\left(\mathcal{R}_{L}, \mathcal{R}_{U}\right)$. Podemos provar que qualquer elemento $C$ de $\mathcal{X}\left(\mathcal{R}_{L}, \mathcal{R}_{U}\right)$, com $C \subset A$, possui custo maior que $A$, e qualquer elemento $D$ de $\mathcal{X}\left(\mathcal{R}_{L}, \mathcal{R}_{U}\right)$, com $B \subset D$, possui custo maior que $B$. Usando essa propriedade, os conjuntos de restrições inferiores e superiores podem ser atualizados, respectivamente, por $A$ e $B$ (linhas 12-17). A Figura 3.3 apresenta uma representação esquemática de uma primeira iteração do algoritmo e os elementos contidos nas constrições $[\emptyset, A=1 \ldots 1010 \ldots 0]$ e $[B=1 \ldots 11110 \ldots 0, W]$.

- A lista de resultados pode ser atualizada com $M$ (linha 18), isto é, $M$ será incluído na lista de resultados se ele tiver custo menor (ou igual) aos elementos já armazenados nela. A lista de resultados pode ainda guardar não apenas os elementos de custo mínimo mas, também, uma lista com um número parametrizado de elementos com os custos mais baixos.

- Visando prevenir o reprocessamento do elemento $M$, um procedimento recursivo denominado de esgotamento do mínimo é executado (linha 19).

Se a direção superior-inferior for a selecionada, o processo Superior-Inferior é executado (Algoritmo 3). Note a dualidade desse processo com o anterior. Ele inicia com um elemento maximal $B$ e constrói uma cadeia em sentido superior-inferior a partir desse elemento.

Um elemento é denominado de mínimo esgotado em $\mathcal{L}$ se todos seus elementos adjacentes (superiores e inferiores) possuem custo maior que ele. Essa definição pode ser extendida ao poset $\mathcal{X}\left(\mathcal{R}_{L}, \mathcal{R}_{U}\right)$, isto é, todos os elementos adjacentes (superiores e inferiores) em $\mathcal{X}\left(\mathcal{R}_{L}, \mathcal{R}_{U}\right)$ possuem custo maior que ele. Na Figura 3.1 podemos ver que os elementos 1010, 1001 e 0111 são mínimos esgotados em $\mathcal{X}\left(\mathcal{R}_{L}, \mathcal{R}_{U}\right)$, mas 1001 não é um mínimo esgotado em $\mathcal{L}$. Neste trabalho, o termo mínimo esgotado será aplicado sempre se referindo ao poset atual $\mathcal{X}\left(\mathcal{R}_{L}, \mathcal{R}_{U}\right)$.

O procedimento esgotamento do mínimo (Algoritmo 4) é um processo recursivo que visita todos os elementos vizinhos de um dado elemento $M$ e os transforma em mínimos esgotados no poset atual $\mathcal{X}\left(\mathcal{R}_{L}, \mathcal{R}_{U}\right)$. Para a recursão, o processo usa uma pilha $\mathcal{S}$. A pilha $\mathcal{S}$ é iniciada empilhando-se $M$ à ela e o processo é executado enquanto $\mathcal{S}$ não for vazia (linhas 2-22). Em cada iteração, o procedimento processa o elemento $T$ no topo de $\mathcal{S}$ : todos os elementos adjacentes (superiores e inferiores) a $T$ em $\mathcal{X}\left(\mathcal{R}_{L}, \mathcal{R}_{U}\right)$ que ainda não estão empilhados em $\mathcal{S}$ são checados. Se o custo de um elemento $A$ adjacente a $T$ é menor (ou igual) ao custo de $T$, então esse elemento é empilhado em $\mathcal{S}$. Se o custo de $A$ for maior que o custo de $T$, então um dos conjuntos de 


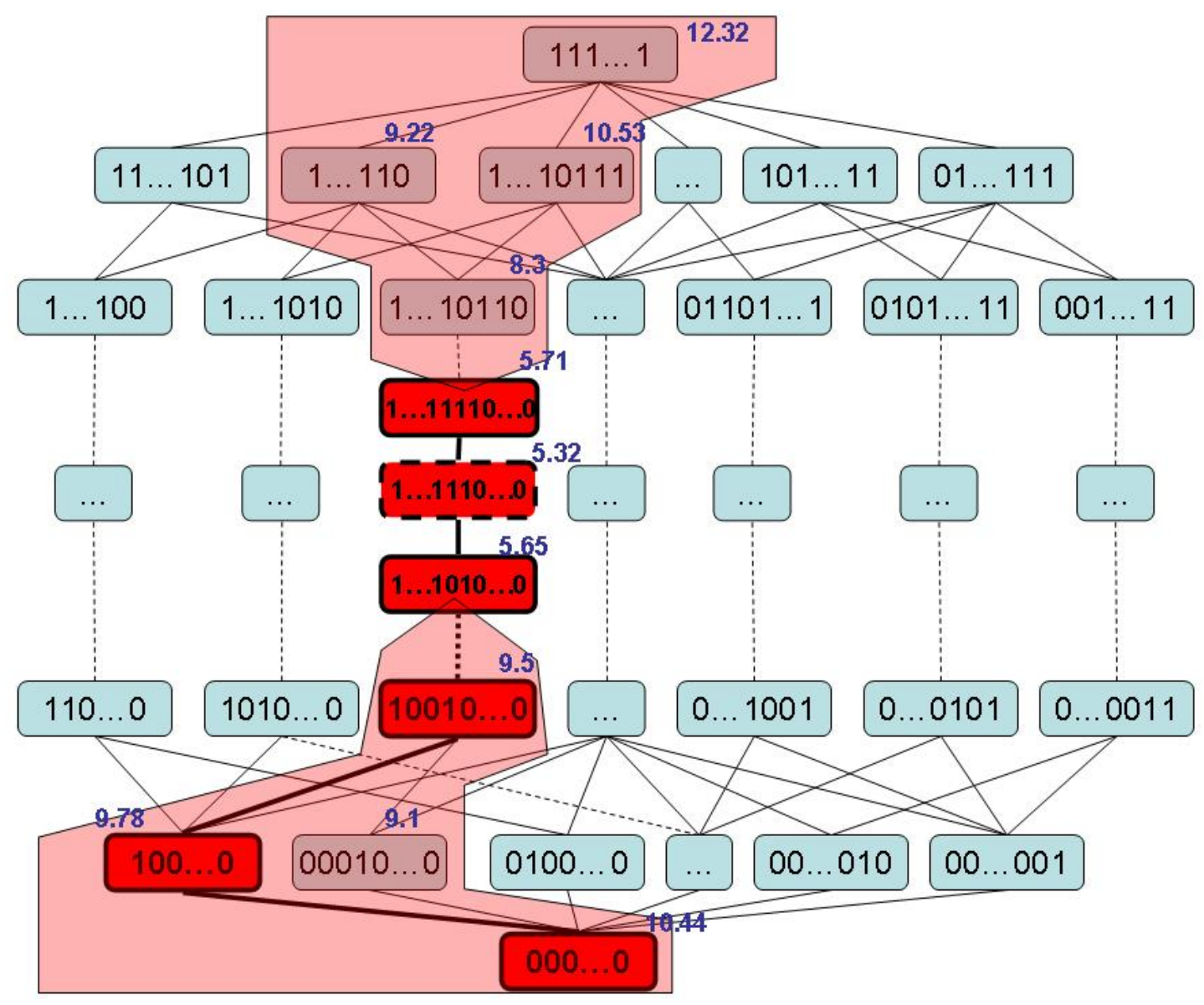

Figura 3.3: Representação esquemática de um passo do algoritmo U-curve. As áreas em destaque representam os elementos contidos nas restrições inferiores e superiores 

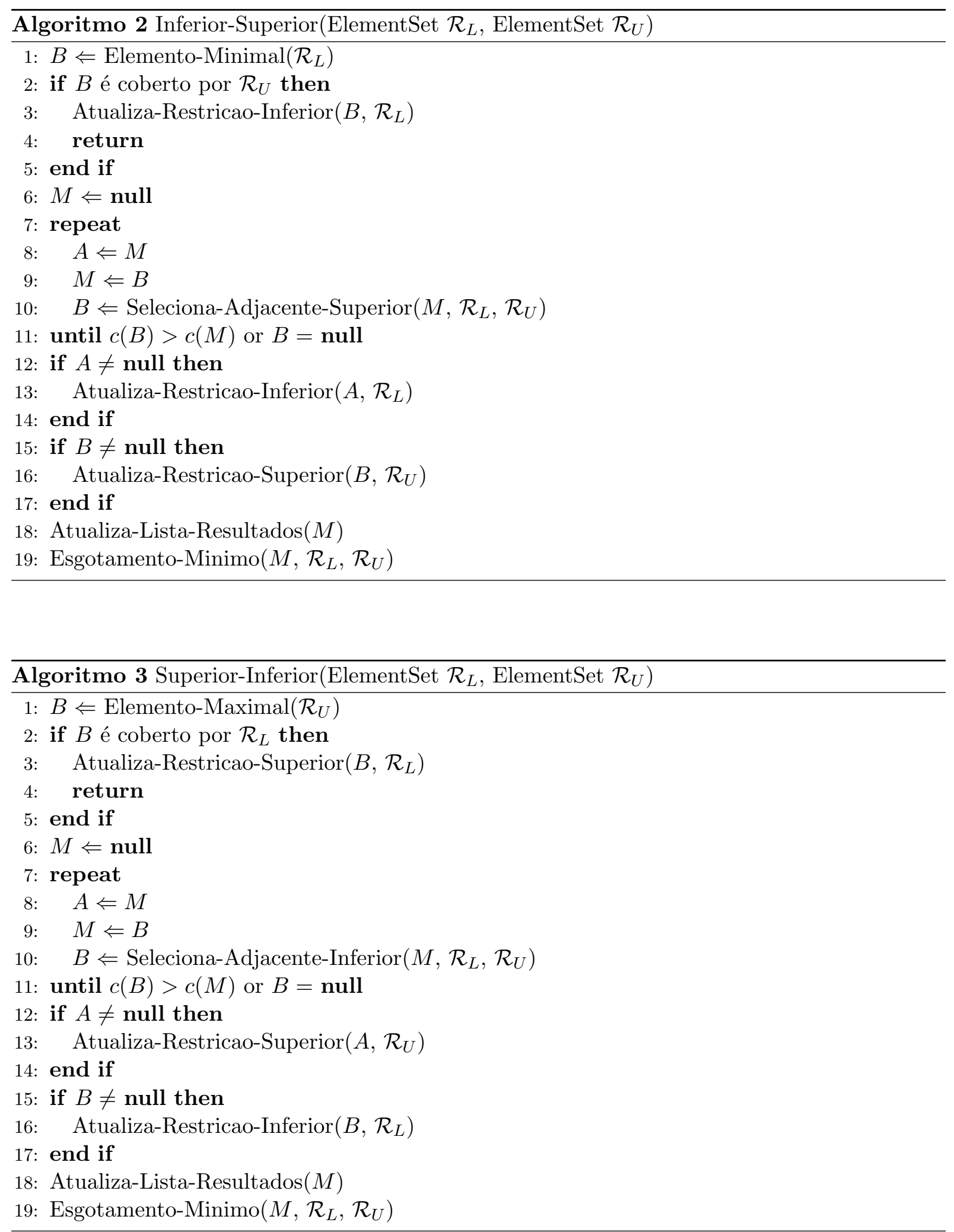


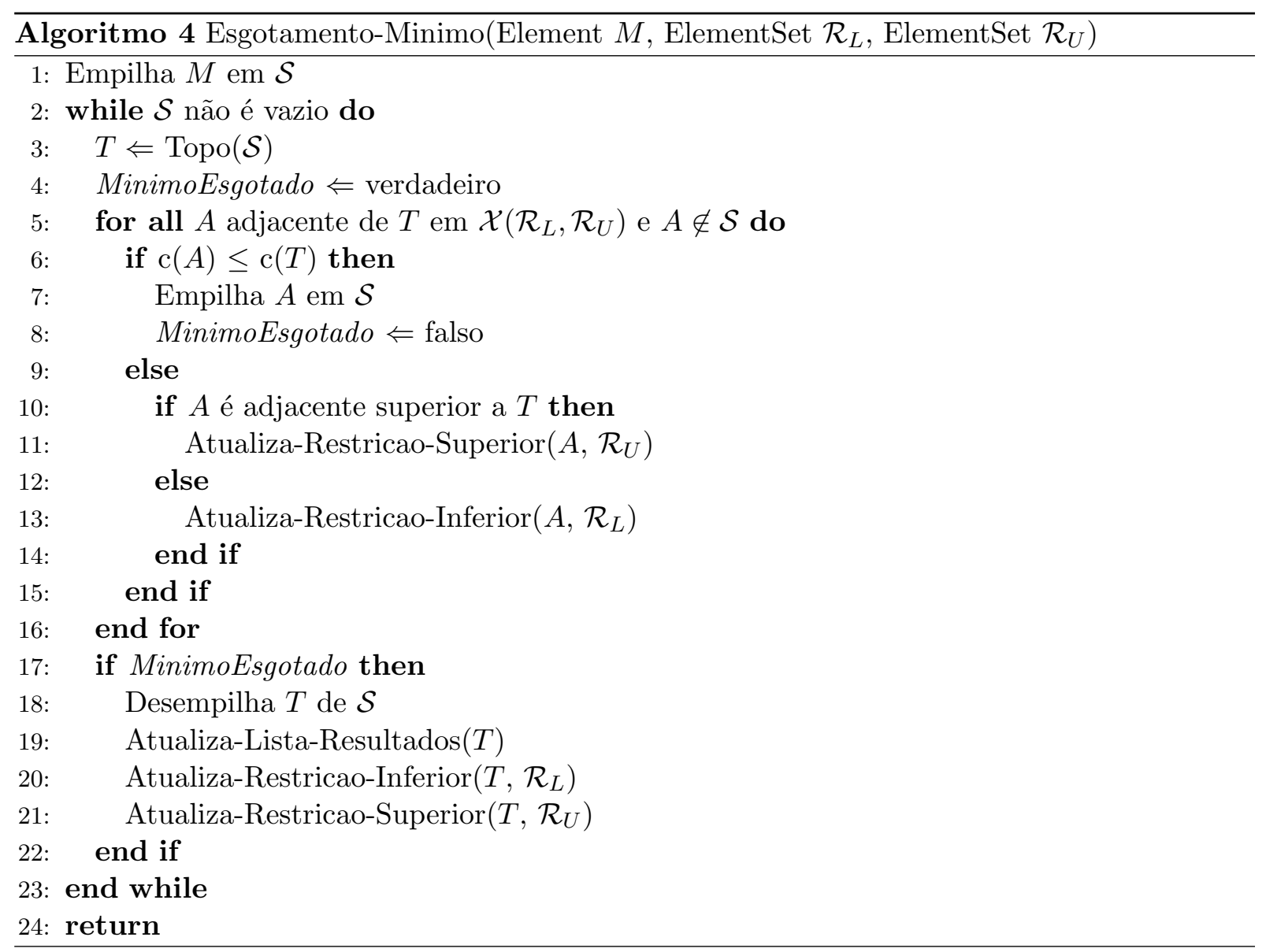


restrições pode ser atualizada com $A$ : o conjunto de restrições inferiores, se $A$ é adjacente inferior a $T$, e o conjunto de restrições superiores, se $A$ é adjacente superior a $T$ (linhas 5-16). Se $T$ é mínimo esgotado em $\mathcal{X}\left(\mathcal{R}_{L}, \mathcal{R}_{U}\right)$, isto é, não existe elemento adjacente $A$ em $\mathcal{X}\left(\mathcal{R}_{L}, \mathcal{R}_{U}\right)$ com custo menor do que $T$, então $T$ é desmpilhado de $\mathcal{S}$, e ambos, os conjuntos de restrições e a lista de resultados, são atualizados com $T$ (linhas 19-21). Ao final desse procedimento todos os elementos processados se transformam em mínimos esgotados no poset atualizado $\mathcal{X}\left(\mathcal{R}_{L}, \mathcal{R}_{U}\right)$.

A Figura 3.4 mostra uma representação gráfica do processo de esgotamento do mínimo. A Figura 3.4-A mostra o processo de construção de uma cadeia na direção inferior-superior. Essa cadeia possui suas arestas enfatizadas na figura. O elemento $M=010101$ (em laranja) possui o custo mínimo sobre a cadeia. Os elementos em preto são os elementos eliminados do espaço de busca pelas restrições obtidas pelos elementos adjacentes (inferiores e superiores) ao mínimo local $M$. A pilha é iniciada com o elemento $M$. A Figura 3.4-B mostra a primeira iteração do processo de esgotamento do mínimo. As arestas em vermelho e os elementos em vermelho indicam os elementos adjacentes a $M$ (topo da pilha) que possuem custo menor (ou igual) a ele. Esses elementos (010001 e 010111), por sua vez, são empilhados. Os elementos adjacentes a $M$, com custo maior do que ele, atualizam os conjuntos de restrições, isto é, o elemento adjacente inferior 000101 atualiza o conjunto de restrições inferiores, e o elemento adjacente superior 000101 atualiza o conjunto de restrições superiores. A Figura 3.4-C mostra a segunda iteração: os elementos adjacentes 010011 e 000111 com custos menores (ou iguais) ao novo topo 010111 são empilhados, e os elementos adjacentes 010110 e 011111 com custo maior que 010111 atualizam, respectivamente, os conjuntos de restrições inferiores e superiores. Na Figura 3.4-D o elemento 000111 é um mínimo esgotado (em cinza) em $\mathcal{X}\left(\mathcal{R}_{L}, \mathcal{R}_{U}\right)$ e ele é desempilhado. Na Figura 3.4-E os elementos eliminados pela novas constrições $[\emptyset, 000111]$ e $[000111, W]$ são destacados na cor preta. A partir desse ponto, 010011 é um mínimo esgotado (em cinza) em $\mathcal{X}\left(\mathcal{R}_{L}, \mathcal{R}_{U}\right)$ e ele é desempilhado. Da Figura 3.4-F à Figura 3.4-H, todos os elementos da pilha são desempilhados e os elementos removidos do espaço de busca pelas novas restrições são destacados em preto. A Figura 3.4-H mostra todos os elementos removidos (em preto) do espaço de busca pela execução do processo de esgotamento do mínimo uma única vez.

Os procedimentos para o cálculo dos elementos minimais e maximais e para a atualização dos conjuntos de restrições inferiores e superiores serão discutidos na próxima Seção.

\subsection{Fundamentos Matemáticos}

Esta Seção introduz os fundamentos matemáticos de alguns módulos do algoritmo U-curve.

\subsubsection{Procedimento de obtenção dos elementos minimais e maximais}

Um grande número de elementos minimais e maximais dos posets $\mathcal{X}\left(\mathcal{R}_{L}\right)$ e $\mathcal{X}\left(\mathcal{R}_{U}\right)$, respectivamente, podem ser obtidos em um passo do algoritmo. Aqui apresentaremos uma solução simples para obtê-los.

Seja $\mathcal{L}$ o reticulado Booleano completo de ordem $n$ e $A$ um elemento de $\mathcal{L}$. O elemento $A^{c}$ representa o conjunto complementar ao conjunto representado pelo elemento $A$ em $\mathcal{L}$, isto é, $A^{c}=W \backslash\{A\}$. Por exemplo, se $A=00101$ então $A^{c}=11010$. 


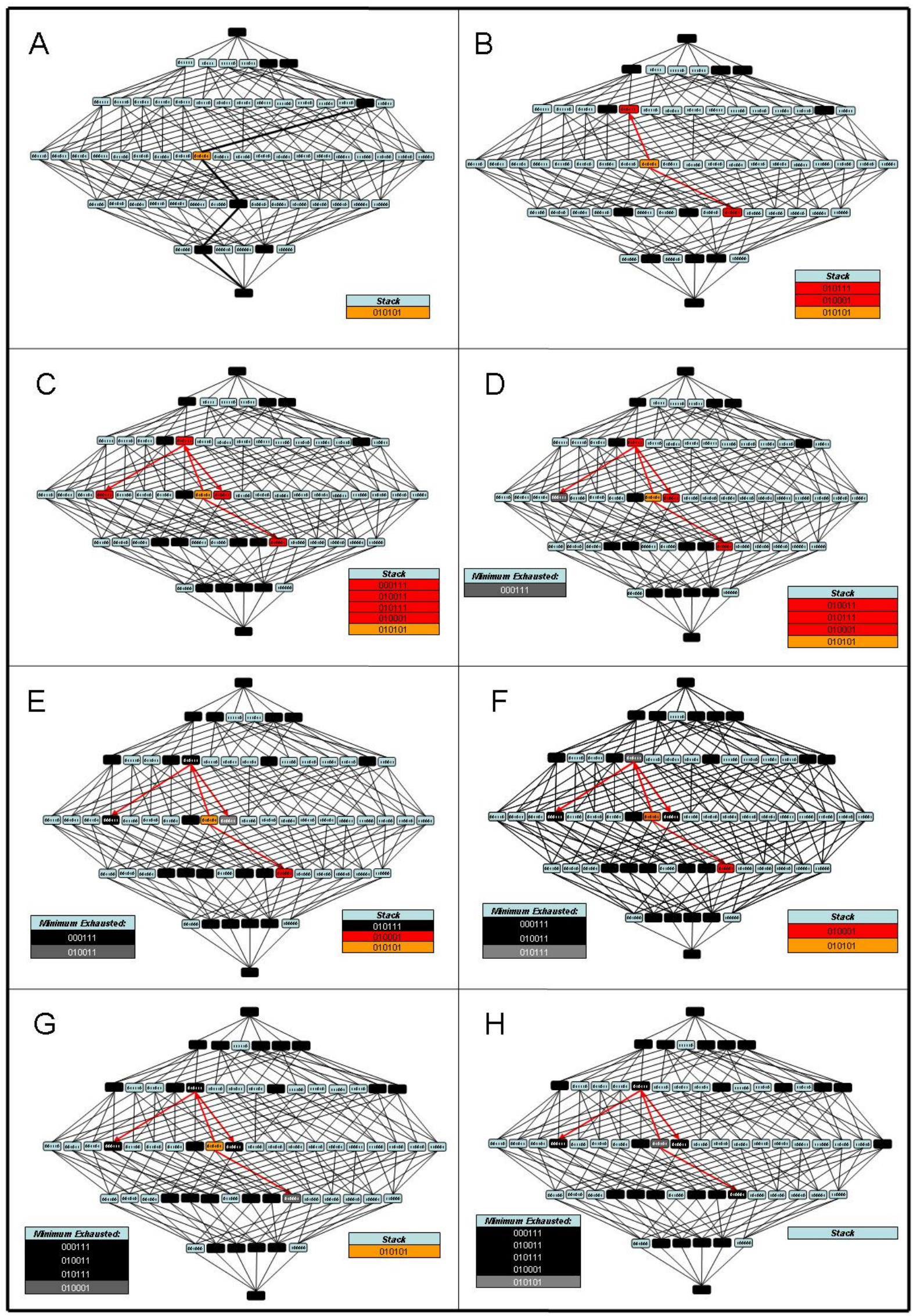

Figura 3.4: Representação gráfica do processo de esgotamento do mínimo 
Teorema 1. Para todo $A \in \mathcal{X}\left(\mathcal{R}_{L}\right)$,

$$
A \in \mathcal{X}\left(\mathcal{R}_{L}\right) \Leftrightarrow A \cap R^{c} \neq \emptyset, \forall R \in \mathcal{R}_{L}
$$

Demonstração.

$$
\begin{aligned}
A \in \mathcal{X}\left(\mathcal{R}_{L}\right) & \Leftrightarrow A \in \mathcal{L}-\bigcup\left\{[\emptyset, R]: R \in \mathcal{R}_{L}\right\} \\
& \left.\Leftrightarrow A \notin \bigcup\{\emptyset, R]: R \in \mathcal{R}_{L}\right\} \\
& \Leftrightarrow A \notin[\emptyset, R], \forall R \in \mathcal{R}_{L} \\
& \Leftrightarrow A \nsubseteq R, \forall R \in \mathcal{R}_{L} \\
& \Leftrightarrow A \cap R^{c} \neq \emptyset, \forall R \in \mathcal{R}_{L}
\end{aligned}
$$

O algoritmo 5 implementa o procedimento de construção do minimal. Ele constrói um elemento minimal $C$ do poset $\mathcal{X}\left(\mathcal{R}_{L}\right)$. O processo começa com $C=(\underbrace{1 \ldots 1}_{n})$ e $S=(\underbrace{1 \ldots 1}_{n})$, e executa $n$ iterações (linhas 3-16) tentando remover componentes de $C$. A cada iteração, uma componente $k, k \in\{1, \ldots, n\}$ é selecionada de $S$. $S$ previne multi-seleção de uma mesma componente. Se um elemento $C^{\prime}$ resultante de $C$ pela remoção da componente $k$ está contido em $\mathcal{X}\left(\mathcal{R}_{L}\right)$, então $C$ é atualizado por $C^{\prime}$ (linhas 7-15).

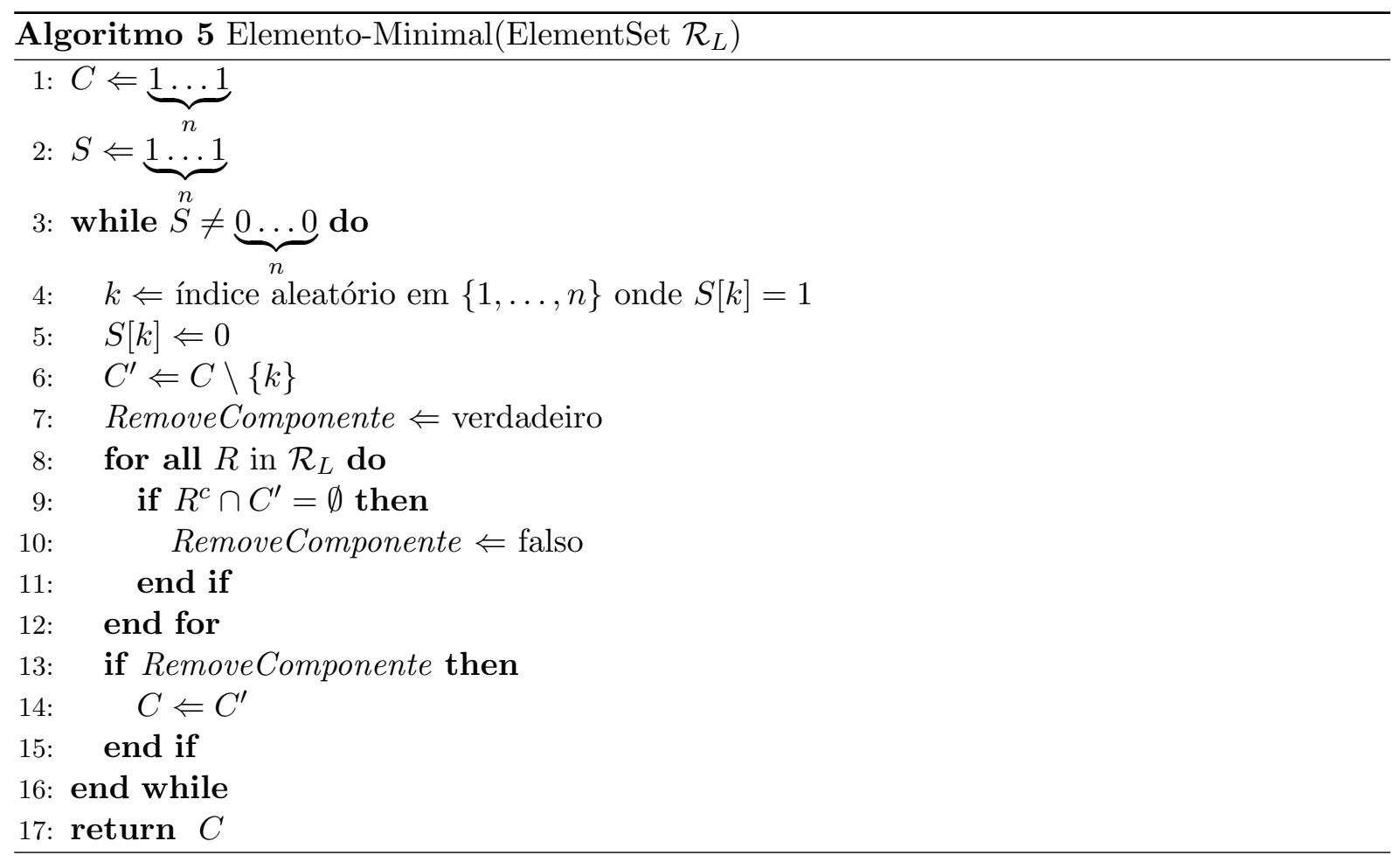


O elemento minimal calculado é igual a $\underbrace{1 \ldots 1}_{n}$ quando $\mathcal{R}_{L}=\{\underbrace{1 \ldots 1}_{n}\}$. Neste ponto, o poset $\mathcal{X}\left(\mathcal{R}_{L}, \mathcal{R}_{U}\right)$ é vazio e o algoritmo pára na próxima iteração.

O próximo teorema demonstra a validade do Algoritmo 5.

Teorema 2. O elemento $C$ de $\mathcal{X}\left(\mathcal{R}_{L}\right)$ obtido pelo processo de construção do minimal (Algoritmo 5) é um elemento minimal em $\mathcal{X}\left(\mathcal{R}_{L}\right)$.

Demonstração. Analisando os passos do processo de construção do minimal temos:

- As linhas 7-15 garantem que em qualquer iteração do processo o elemento resultante $C$ está contido em $\mathcal{X}\left(\mathcal{R}_{L}\right)$, isto é, ele só é alterado quando o elemento $C^{\prime}$ satisfaz a condição do Teorema 1.

- Sejam $C_{1}, \ldots, C_{n}$ a seqüência dos elementos resultantes a cada iteração $i(i=1, \ldots, n)$ do processo e $C_{0}=\underbrace{1 \ldots 1}_{n}$ o elemento inicial. Como um índice $k$ é escolhido para ser removido de $C_{i-1}$ (linhas 4-6) a cada iteração $i$, isso implica que $C_{n} \subseteq C_{n-1} \subseteq \ldots \subseteq C_{0}$.

- Provar que o elemento resultante $C_{n}$ é minimal em $\mathcal{X}\left(\mathcal{R}_{L}\right)$ é equivalente a provar que $\forall l \in C_{n}, C_{n} \backslash\{l\} \notin \mathcal{X}\left(\mathcal{R}_{L}\right)$.

- Seja $k=l, l \in C_{n}$ e $i$ a iteração do processo quando o índice $l$ é escolhido para ser removido de $C_{i-1}$. $C_{n} \subseteq C_{i}$ e $l \in C_{n}$, implica que $l \in C_{i}$, isto é, $l$ não pode ser removido de $C_{i-1}$ ao final da iteração $i$. Isso é evitado pelo algoritmo (linhas 8-12) quando existe um elemento $R \in \mathcal{R}_{L} \operatorname{com} R^{c} \cap\left(C_{i-1} \backslash\{l\}\right)=\emptyset$. Como $C_{n} \backslash\{l\} \subseteq C_{i-1} \backslash\{l\}$, então $R^{c} \cap\left(C_{n} \backslash\{l\}\right)=\emptyset$ e, pelo Teorema $1, C_{n} \backslash\{l\} \notin \mathcal{X}\left(\mathcal{R}_{L}\right)$. Isso implica que $C_{n}$ é um elemento minimal em $\mathcal{X}\left(\mathcal{R}_{L}\right)$.

O processo para a obtenção dos elementos maximais é dual ao minimal.

Teorema 3. Para todo $A \in \mathcal{X}\left(\mathcal{R}_{U}\right)$,

$$
A \in \mathcal{X}\left(\mathcal{R}_{U}\right) \Leftrightarrow A^{c} \cap R \neq \emptyset, \forall R \in \mathcal{R}_{U}
$$

Demonstração.

$$
\begin{aligned}
A \in \mathcal{X}\left(\mathcal{R}_{U}\right) & \Leftrightarrow A \in \mathcal{L}-\bigcup\left\{[R, W]: R \in \mathcal{R}_{U}\right\} \\
& \Leftrightarrow A \notin \bigcup\left\{[R, W]: R \in \mathcal{R}_{U}\right\} \\
& \Leftrightarrow A \notin[R, W], \forall R \in \mathcal{R}_{U} \\
& \Leftrightarrow R \nsubseteq A, \forall R \in \mathcal{R}_{U} \\
& \Leftrightarrow R \cap A^{c} \neq \emptyset, \forall R \in \mathcal{R}_{U}
\end{aligned}
$$


O algoritmo 6 implementa o procedimento de construção do maximal. Podemos notar a sua dualidade com o da construção do minimal. O processo começa com $C=(\underbrace{0 \ldots 0}_{n})$ e $S=(\underbrace{1 \ldots 1}_{n})$, e executa $n$ iterações (linhas 3-16) tentando adicionar componentes ao elemento $C$. A cada iteração, uma componente $k, k \in\{1, \ldots, n\}$ é selecionada de $S$. Se um elemento $C^{\prime}$ resultante de $C$ pela remoção da componente $k$ está contido em $\mathcal{X}\left(\mathcal{R}_{U}\right)$, então $C$ é atualizado por $C^{\prime}$ (linhas 7-15).

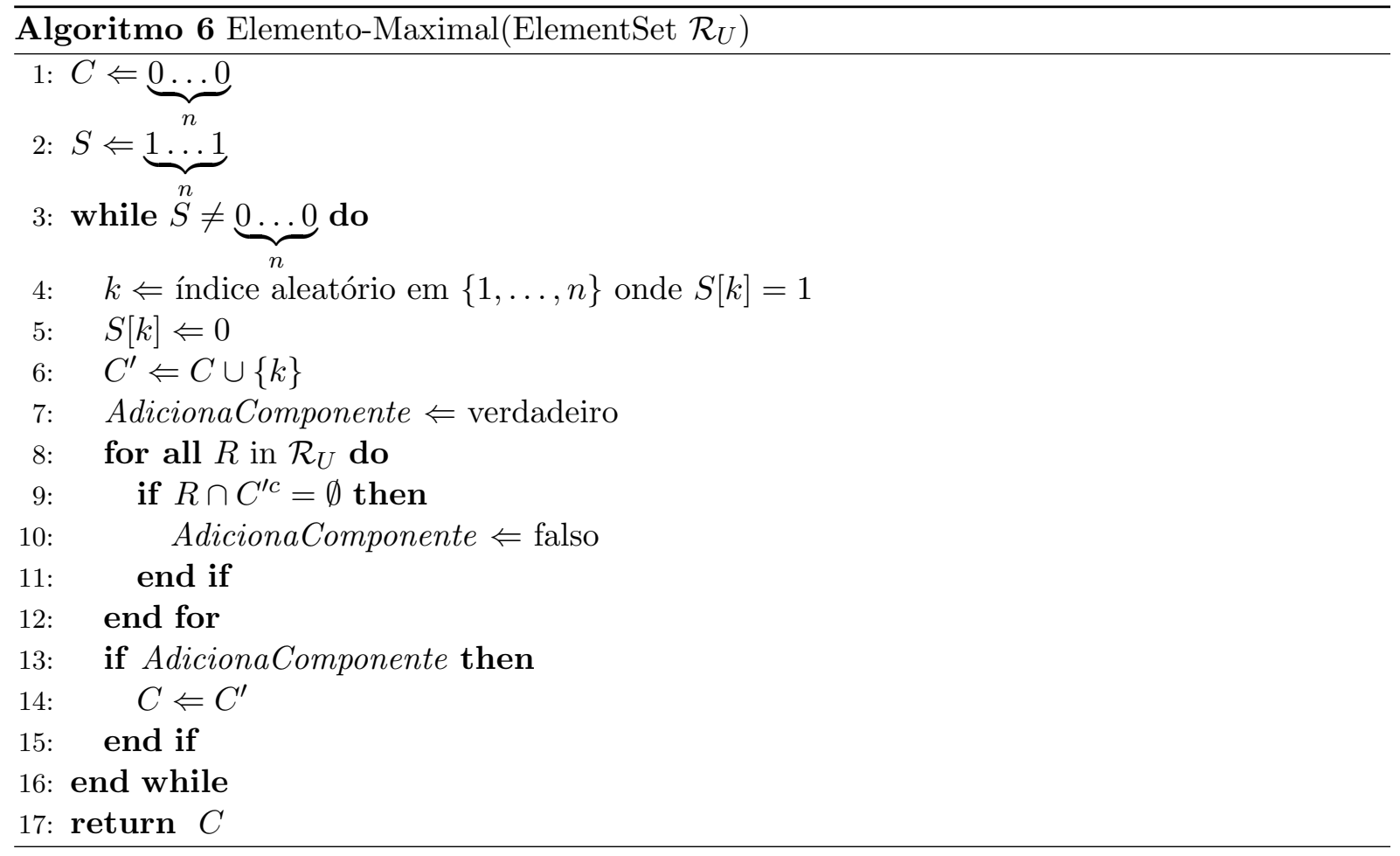

Também de forma dual o Teorema 4 demonstra a validade do Algoritmo 6.

Teorema 4. O elemento $C$ de $\mathcal{X}\left(\mathcal{R}_{U}\right)$ obtido pelo processo de construção do maximal (Algoritmo 6) é um elemento maximal em $\mathcal{X}\left(\mathcal{R}_{U}\right)$.

Demonstração. Analisando os passos do processo de construção do maximal temos:

- As linhas 7-15 garantem que em qualquer iteração do processo o elemento resultante $C$ está contido em $\mathcal{X}\left(\mathcal{R}_{U}\right)$, isto é, ele só é alterado quando o elemento $C^{\prime}$ satisfaz a condição do Teorema 3 .

- Sejam $C_{1}, \ldots, C_{n}$ a seqüência dos elementos resultantes a cada iteração $i(i=1, \ldots, n)$ do processo e $C_{0}=\underbrace{0 \ldots 0}_{n}$ o elemento inicial. Como um índice $k$ é escolhido para ser adicionado a $C_{i-1}\left(\right.$ linhas 4-6) a cada iteração $i$, isso implica que $C_{0} \subseteq C_{1} \subseteq \ldots \subseteq C_{n}$.

- Provar que o elemento resultante $C_{n}$ é maximal em $\mathcal{X}\left(\mathcal{R}_{L}\right)$ é equivalente a provar que $\forall l \notin C_{n}, C_{n} \cup\{l\} \notin \mathcal{X}\left(\mathcal{R}_{U}\right)$. 
- Seja $k=l, l \notin C_{n}$ e $i$ a iteração do processo quando o índice $l$ é escolhido para ser adicionado a $C_{i-1} . C_{i} \subseteq C_{n}$ e $l \notin C_{n}$ implica que $l \notin C_{i}$, isto é, $l$ não pode ser adicionado a $C_{i-1}$ ao final da iteração $i$. Isso é evitado pelo algoritmo (linhas 8-12) quando existe um elemento $R \in \mathcal{R}_{L} \operatorname{com} R \cap\left(C_{i-1} \cup\{l\}\right)^{c}=\emptyset$. Como $C_{i-1} \cup\{l\} \subseteq C_{n} \cup\{l\}$ e $\left(C_{i-1} \cup\{l\}\right)^{c} \supseteq\left(C_{n} \cup\{l\}\right)^{c}$, então $R \cap\left(C_{n} \cup\{l\}\right)^{c}=\emptyset$ e, pelo Teorema $3, C_{n} \cup\{l\} \notin \mathcal{X}\left(\mathcal{R}_{U}\right)$. Isso implica que $C_{n}$ é um elemento maximal em $\mathcal{X}\left(\mathcal{R}_{U}\right)$.

\subsubsection{Atualização dos conjuntos de restrições}

Os conjuntos de restrições $\mathcal{R}_{L}$ e $\mathcal{R}_{U}$ representam o espaço de busca. Sendo assim, eles são atualizados após cada nova busca pela seguite regra: um elemento $A$ é adicionado ao conjunto de restrições inferiores (ou superiores) se todos os elementos contidos em $[\emptyset, A]$ (ou $[A, W]$ ) possuem custo maior ou igual a $A$.

Os conjuntos de restrições são os responsáveis pela redução significativa do espaço de busca. O conjunto de restrições inferiores $\mathcal{R}_{L}=\left\{R_{1}, \ldots, R_{m}\right\}$ transforma o espaço de busca $\mathcal{L}$ no espaço restringido $\mathcal{X}\left(\mathcal{R}_{L}\right)=\mathcal{L}-\bigcup\left\{[\emptyset, R]: R \in \mathcal{R}_{L}\right\}$.

O próximo teorema estabelece a condição $U$-curve, a qual permite que o processo de construção da cadeia pare e os conjuntos de restrições sejam atualizados.

Teorema 5. Sejam $C_{0}, \ldots, C_{k-1}, C_{k}$ a cadeia construída pelo Algoritmo 2 (ou sua versão dual). Seja c a função custo do reticulado $\mathcal{L}$ em $\mathbb{R}$ decomponível em curvas em $U$ e $c\left(C_{k}\right)>c\left(C_{k-1}\right)$. É verdade que:

$$
\forall A \in \mathcal{L}, C_{k} \subseteq A \Rightarrow c(A) \geq c\left(C_{k}\right)
$$

Demonstração. Suponha que $\exists B \in \mathcal{L}, C_{k} \subseteq B$ e $c(B)<c\left(C_{k}\right)$. Por hipótese, $c$ é uma função decomponível em curvas em $\mathrm{U}$ e como $C_{k-1} \subseteq C_{k} \subseteq B$, então $\max \left(c\left(C_{k-1}\right), c(B)\right)>c\left(C_{k}\right)$. Por outro lado, $\max \left(c\left(C_{k-1}\right), c(B)\right)$ é ou $c\left(C_{k-1}\right)\left(c\left(C_{k-1}\right)<c\left(C_{k}\right)\right.$, por hipótese) ou $c(B)$ $\left(c(B)<c\left(C_{k}\right)\right.$, por suposição), $\operatorname{logo} \max \left(c\left(C_{k-1}\right), c(B)\right)<c\left(C_{k}\right)$, contradizendo a hipótese.

Com uma demonstração semelhante a apresentada para o Teorema 5, pode-se provar, também, que todos os elementos de $\mathcal{L}$ contidos em $C_{k-2}$ possuem custo maior ou igual a ele. A Figura 3.3 mostra a cadeia obtida pelo processo de contrução da cadeia e o poset resultante. Os elementos em destaque possuem custos maiores que os elementos $C_{k}=(1 \ldots 11110 \ldots 0)$ ou $C_{k-2}=(1 \ldots 1010 \ldots 0)$.

O Algoritmo 7 descreve o processo de atualização do conjunto de restrições inferiores a partir de um elemento $A$. Se $A$ já é coberto por $\mathcal{R}_{L}$, isto é, existe um elemento de $\mathcal{R}_{L}$ que contém $A$, então o processo se encerra (linhas 1-3). Caso contrário, todos elementos em $\mathcal{R}_{L}$ contidos em $A$ são removidos de $\mathcal{R}_{L}$ e $A$ é adicionado a $\mathcal{R}_{L}$ (linhas 4-9). Esse procedimento possui o efeito de compactar o conjunto de restrições sem alterar o poset resultante $\mathcal{X}\left(\mathcal{R}_{L}\right)$, já que as restrições removidas estão contidas em $A$. 


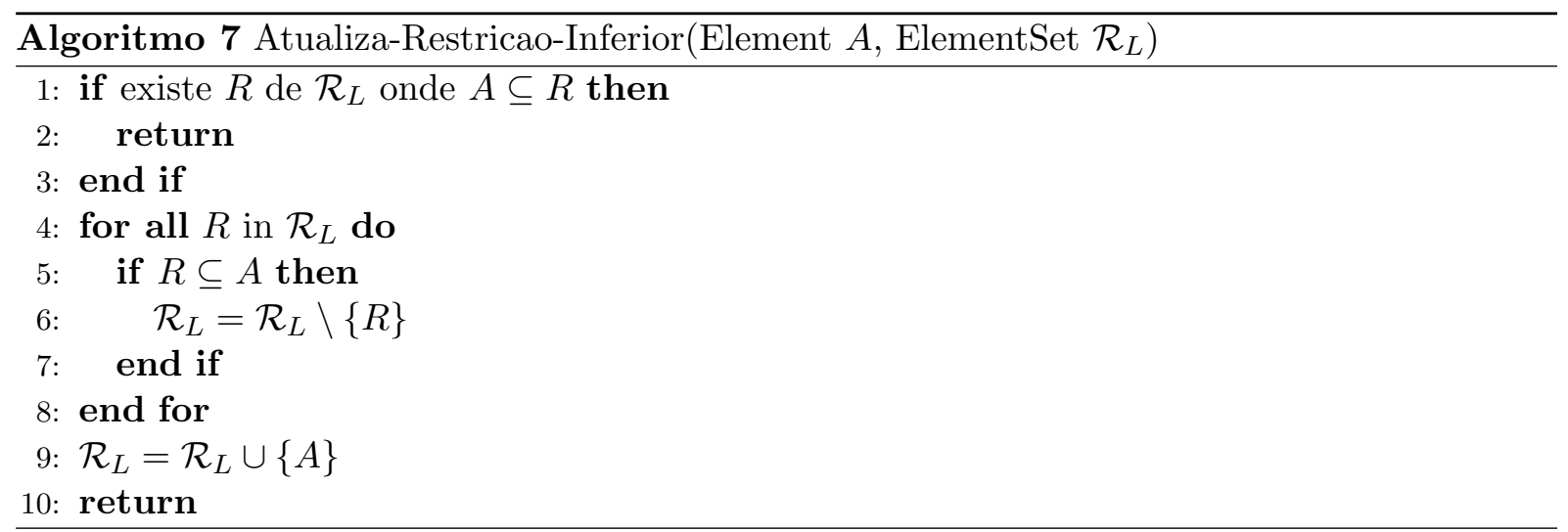

A atualização do conjunto de restrições superiores é dual ao de inferiores e, nesse caso, procuramos elementos que estejam contidos em $A$ ao invés de elementos que contêm $A$ para indicar se $A$ deve ser inserido em $\mathcal{R}_{L}$. O Algoritmo 8 descreve o processo de atualização do conjunto de restrições superiores a partir de um elemento $A$.

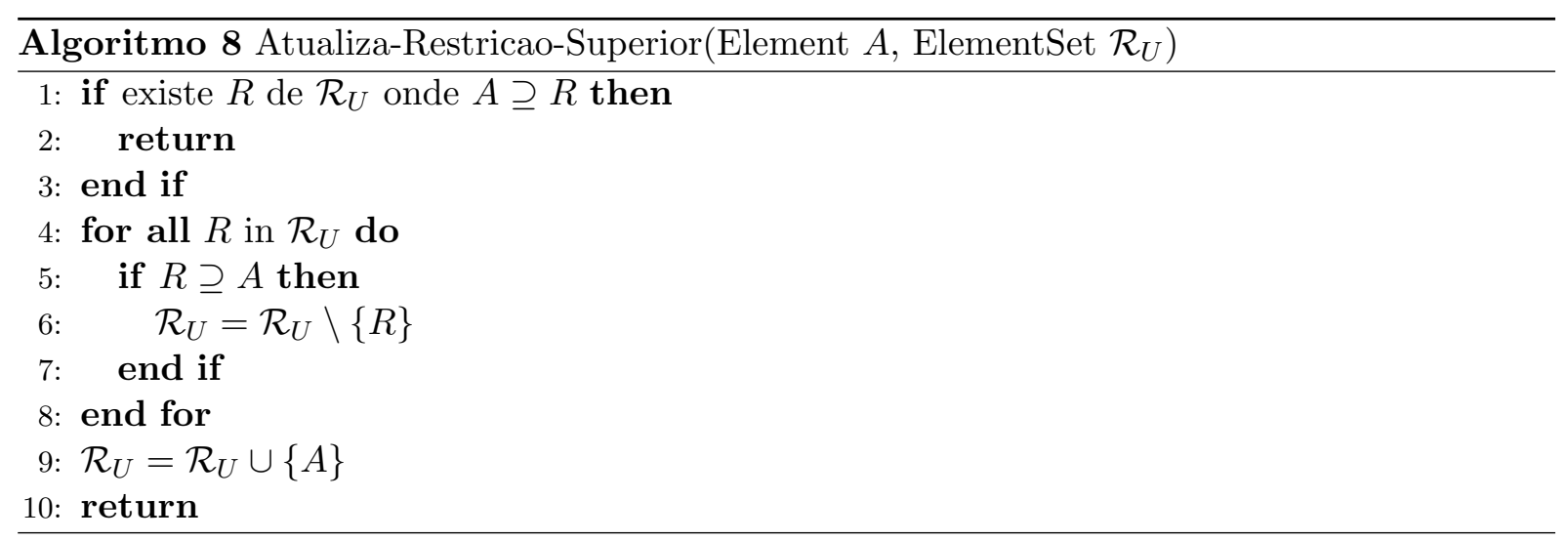

\subsubsection{Esgotamento do mínimo}

O cálculo computacional da função custo é em geral muito custoso. Sendo assim, é desejável que cada elemento seja visitado e seu custo computado uma única vez. Uma maneira de evitar esse reprocessamento é aplicar o procedimento de esgotamento do mínimo. Esse procedimento é uma função recursiva (Algoritmo 4). Ele usa uma pilha $\mathcal{S}$ para processar recursivamene todos os elementos próximos de um dado elemento $M$ contidos no poset atual $\mathcal{X}\left(\mathcal{R}_{L}, \mathcal{R}_{U}\right)$. Em cada recursão, os elementos adjacentes (superiors e inferiores) ao elemento do topo de $\mathcal{S}$, em $\mathcal{X}\left(\mathcal{R}_{L}, \mathcal{R}_{U}\right)$, e não em $\mathcal{S}$, são visitados. Os elementos adjacentes com custo maior que $T$ são elementos que satisfazem a condição $U$-curve e podem atualizar os respectivos conjuntos de restrições e, conseqüentemente, serem removidos do espaço de busca. Os elementos adjacentes com custo menor (ou igual) a $T$ são empilhados em $\mathcal{S}$ para serem processados depois. Note que esses elementos não são reprocessados ao longo do método: eles ou estão em um conjunto de restriçõe, ou não se repetem em $\mathcal{S}$. Se $T$ é um elemento mínimo esgotado em $\mathcal{X}\left(\mathcal{R}_{L}, \mathcal{R}_{U}\right)$, então $T$ é removido de $\mathcal{S}$. Depois que o processo é finalizado, todos os elementos são removidos do 
poset resultante $\mathcal{X}\left(\mathcal{R}_{L}, \mathcal{R}_{U}\right)$, o que previne seus reprocessamentos. O fato de um elemento não poder ser reprocessado implica no fato de que o procedimento termina após alguns passos (sem entrar em ciclo infinito), isto é, o número de elemenos em $\mathcal{X}\left(\mathcal{R}_{L}, \mathcal{R}_{U}\right)$ é finito (limitado pelo número de elementos do espaço total), e ele é um limitante superior para o número de passos do procedimento. Em alguns casos, esse procedimento pode ter que processar um número muito grande de elementos, e algumas heurísticas devem ser implementadas para lidar com eles. Por exemplo: parar a recursão após alguns passos sem a alteração do valor encontrado para o custo mínimo.

O procedimento de esgotamento do mínimo adiciona uma outra propriedade interessante ao algoritmo U-curve. Se a função custo em uma cadeia maximal descreve uma curva em U com oscilações, como as ilustradas na Figura 3.5-A, o algoritmo $U$-curve pode perder algum mínimo local (no caso, o elemento mínimo local após as oscilações tem custo menor que o anterior). Apesar disso, esse mínimo não é perdido se existir outra cadeia, com uma função custo descrevendo realmente uma curva em forma de U, contendo os dois mínimos locais. A Figura 3.5-B mostra uma cadeia alternativa (em vermelho) para alcançar o elemento mínimo (em preto). Note que o mínimo local (em amarelo) está contido em ambas as cadeias. Essas cadeias alternativas para atingir os mínimos locais são possíveis pelo procedimento de esgotamento exatamente quando aplicada ao primeiro mínimo. Sendo assim, o procedimento de esgotamento do mínimo permite relaxar a classe de problemas abordados pelo algoritmo $U$-curve.

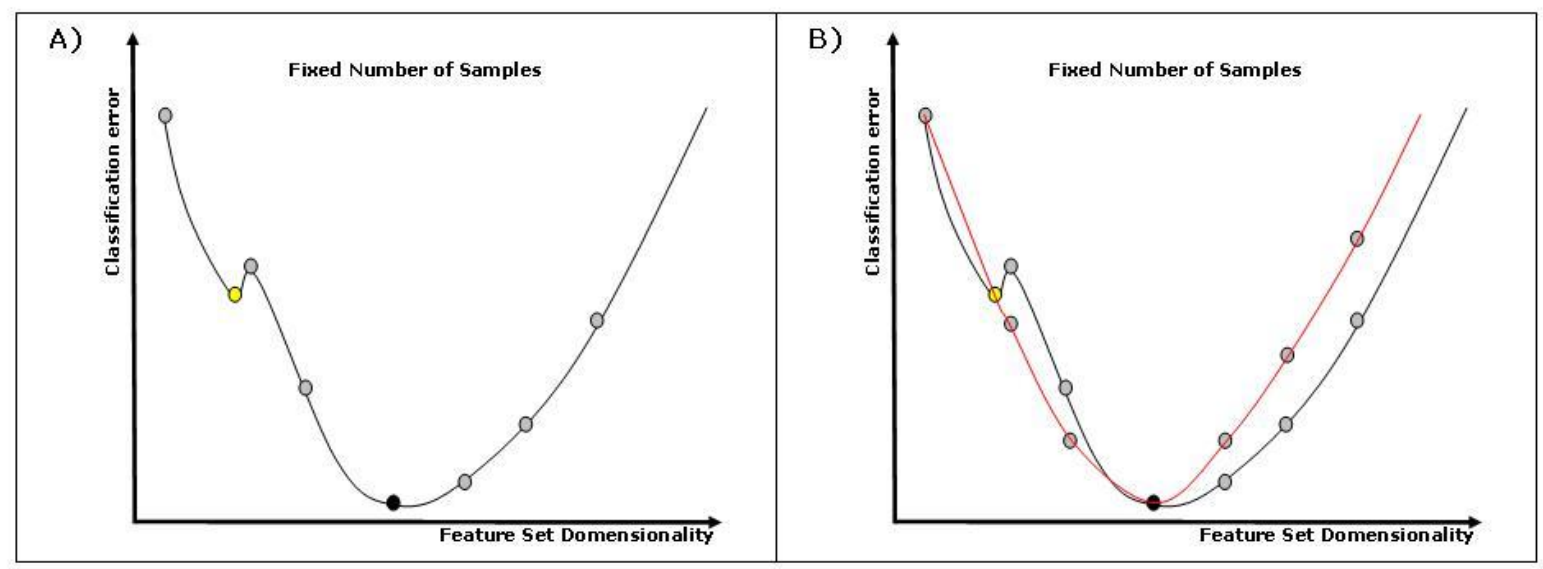

Figura 3.5: Exemplos de curvas de erro com oscilações e caminhos alternativos

\subsection{Resultados experimentais}

Nesta Seção, apresentaremos alguns resultados de aplicações do algoritmo proposto para a seleção de características. Seu desempenho foi comparado com o desempenho do SFFS ("Sequential Floating Forward Selection") [32]. Duas aplicações foram estudadas: desenho de $W$ operadores [22] e identificação de preditores para redes genéticas. Em ambos os casos, foi atribuído valor 2 para o parâmetro delta do SFFS. 
A função custo é a entropia condicional média com o mesmo método de estimativa usado em [3] e dado por:

$$
\hat{E}\left[H\left(Y \mid \mathbf{X}_{\mathcal{Z}}\right)\right]=\frac{N}{t}+\sum_{\mathbf{x}_{\mathcal{Z}} \in \mathbf{X}_{\mathcal{Z}}: P\left(\mathbf{x}_{\mathcal{Z}}\right)>\frac{1}{t}} P\left(\mathbf{x}_{\mathcal{Z}}\right) H\left(Y \mid \mathbf{x}_{\mathcal{Z}}\right),
$$

onde $H(X)=-\sum_{x \in X} P(x) \log _{c} P(x)$ (entropia de Shannon com base logarítmica igual ao número de possíveis classes $c), t$ é o número total de amostras, $\mathcal{Z}$ é o subconjunto dos índices de características e $N$ é o número total de instâncias com $P\left(\mathbf{x}_{\mathcal{Z}}\right)=\frac{1}{t}$. Nessa equação, as instâncias raramente observadas são aquelas com apenas uma observação no conjunto de treinamento, o que significa que a probabilidade de todas essas instâncias é $\frac{N}{t}$. Sem essa penalização, tais instâncias teriam entropia condicional igual a zero (mínima possível), pois a massa de probabilidades estaria concentrada em apenas uma classe. Essa penalização consiste em atribuir, em conjunto com as classes, uma distribuição uniforme, já que a entropia da distribuição uniforme é máxima (utilizando logaritmo na base $c$, a máxima entropia é 1). Essa função custo descreve uma curva em forma de U pelo fato de que: para uma dimensão suficientemente grande, o número de instâncias com apenas uma observação começa a crescer, crescendo a penalização e, conseqüentemente, crescendo o valor da função custo (novas componentes não adicionam informação suficiente para compensar o erro de estimação).

O problema de seleção de características pode ter funções custo com cadeias que apresentam oscilações e não existe nenhuma garantia teórica da existência de caminhos alternativos para alcançar os mínimos locais além das oscilações. Todavia, esses casos foram testados experimentalmente, e para todos os casos observados, o procedimento de esgotamento do mínimo pode atingir os elementos mínimos locais usando caminhos alternativos. Testamos 100.000 curvas aleatórias para ambos os problemas. Para o problemas desenho de W-operadores, uma média de 24.000 curvas $(24 \%)$ contém partes com oscilações, e para o problema de classificação biológica uma média de 15.000 curvas (15\%) contêm partes com oscilações. Para todas essas curvas com oscilações o procedimento de esgotamento do mínimo encontra o mínimo local por cadeias alternativas .

Os resultados do algoritmo $U$-curve foram divididos em dois conjuntos: UC - até atingir (ou melhorar pela primeira vez) o resultado do SFFS e UCC - até o espaço total de busca ser completamente processado. O algoritmo U-curve é estocástico e, com isso, ele pode atingir o melhor resultado em diferentes tempos de processamento. Para cada teste, processamos o $U$ curve cinco vezes e os resultados da coluna UC indicam uma média dos cinco processamentos. A máquina usada para os testes foi um AMD Turion $64^{\mathrm{TM}}$ com $2 \mathrm{~Gb}$ de memória RAM.

O problema de desenho de $\mathrm{W}$-operadores consiste em procurar subconjuntos de uma janela de tamanho $n$ que possuem o menor erro de estimação (custo), isto é, a imagem obtida pelo processamento do operador calculado possui o melhor resultado desejável dentre todos os operadores possíveis. Para nossos testes, foram usadas imagens binárias como amostras com janela de tamanho $16(4 \times 4)$ e duas classes $(0$ e 1$)$. A Tabela 3.1 mostra o resultado do algoritmo $U$-curve em comparação ao SFFS para 20 testes. A segunda coluna mostra qual processo ( $U$ curve ou SFFS) atinge o melhor resultado (elemento de menor custo). O algoritmo $U$-curve 
melhora o resultado do SFFS em 8 dos 20 testes e atinge resultados iguais nos outros 12 testes (para esses casos, o SFFS atinge o elemento mínimo global). Em todos os testes, o algoritmo $U$-curve atinge o resultado do SFFS (UC) processando um menor número de nós em um tempo menor. A busca completa (UCC) freqüentemente requer mais nós processados $(17 / 20)$ e tempo de execução (19/20) para processar o espaço inteiro.

\begin{tabular}{|c|c|c|c|c|c|c|c|}
\hline Teste & Vencedor & \multicolumn{3}{|c|}{ Nós } & \multicolumn{3}{c|}{ Tempo(seg.) } \\
\hline & & SFFS & UC & UCC & SFFS & UC & UCC \\
\hline 1 & IGUAL & 358 & 73 & 373 & 8 & 2 & 393 \\
\hline 2 & IGUAL & 333 & 31 & 154 & 7 & 1 & 392 \\
\hline 3 & IGUAL & 417 & 17 & 137 & 10 & 1 & 393 \\
\hline 4 & UC & 435 & 58 & 5,965 & 9 & 1 & 541 \\
\hline 5 & UC & 357 & 101 & 223 & 7 & 3 & 385 \\
\hline 6 & UC & 384 & 66 & 345 & 9 & 2 & 399 \\
\hline 7 & IGUAL & 302 & 111 & 266 & 6 & 4 & 392 \\
\hline 8 & UC & 1,217 & 158 & 13,963 & 21 & 2 & 591 \\
\hline 9 & UC & 330 & 31 & 274 & 8 & 1 & 385 \\
\hline 10 & IGUAL & 406 & 113 & 825 & 10 & 4 & 408 \\
\hline 11 & IGUAL & 329 & 70 & 544 & 7 & 2 & 387 \\
\hline 12 & IGUAL & 336 & 17 & 17 & 8 & 0.5 & 0.5 \\
\hline 13 & IGUAL & 310 & 26 & 26 & 8 & 1 & 384 \\
\hline 14 & UC & 328 & 67 & 67 & 8 & 4 & 421 \\
\hline 15 & IGUAL & 425 & 66 & 671 & 8 & 1 & 391 \\
\hline 16 & UC & 333 & 31 & 151 & 8 & 1 & 377 \\
\hline 17 & IGUAL & 1,257 & 659 & 11,253 & 31 & 16 & 717 \\
\hline 18 & UC & 336 & 39 & 218 & 7 & 1 & 385 \\
\hline 19 & IGUAL & 296 & 32 & 137 & 6 & 2 & 379 \\
\hline 20 & IGUAL & 323 & 31 & 151 & 8 & 2 & 376 \\
\hline
\end{tabular}

Tabela 3.1: Comparação entre o resultado do SFFS e o algoritmo U-curve em nós calculados e tempo de execução para o desenho de W-operadores

Um problema de classificação biológica pode ser visto como o problema de se encontrar um bom subconjunto de genes preditores de um específico gene-alvo em um experimento temporal de microarrays. Os dados utilizados para esses testes foram obtidos do artigo em [26]. Eles foram normalizados e discretizados em 3 níveis, utilizando o mesmo método de [3], O subconjunto de preditores foi obtido de um conjunto de 27 genes e os resultados foram comparados ao SFFS. A Tabela 3.2 mostra os resultados de 10 testes utilizando diferentes genes-alvos e suas comparações com os resultados em SFFS. As colunas apresentadas são as mesmas da Tabela 3.1. A busca completa para esses testes é relativamente grande ( $2^{27}$ nós). A heurística SFFS alcançou o melhor elemento, processando um número menor de nós que o algoritmo $U$-curve em apenas $3 / 10$ vezes, e o algoritmo $U$-curve processou o espaço completo encontrando o melhor elemento $(7 / 10)$ processando mais nós, porém com um tempo de processamento aceitável.

O Apêndice A contém uma parte da fonte do algoritmo desenvolvido em $\mathrm{C}++$ e a descrição dos parâmetros que podem ser utilizados para a sua execução. No DVD anexado ao traba- 


\begin{tabular}{|c|c|c|c|c|c|c|c|}
\hline Teste & Vencedor & \multicolumn{3}{|c|}{ Nós } & \multicolumn{3}{|c|}{ Tempo(seg.) } \\
\hline & & SFFS & UC & UCC & SFFS & UC & UCC \\
\hline 1 & IGUAL & 135 & 777 & 9.964 & 0,5 & 0,6 & 3,1 \\
\hline 2 & UC & 135 & 9252 & 30.724 & 0,5 & 2,1 & 11,2 \\
\hline 3 & UC & 135 & 1037 & 9.410 & 0,5 & 0,6 & 3,1 \\
\hline 4 & UC & 164 & 786 & 9.276 & 0,5 & 0,6 & 3,1 \\
\hline 5 & UC & 281 & 247 & 6.126 & 0,5 & 0,6 & 1,5 \\
\hline 6 & IGUAL & 135 & 2675 & 11.031 & 0,5 & 0,7 & 7,3 \\
\hline 7 & IGUAL & 135 & 998 & 10.836 & 0,5 & 0,6 & 6,9 \\
\hline 8 & UC & 135 & 463 & 5.381 & 0,5 & 0,5 & 1,5 \\
\hline 9 & UC & 135 & 246 & 4.226 & 0,5 & 0,5 & 1,5 \\
\hline 10 & UC & 191 & 474 & 8.930 & 0,5 & 0,5 & 2,9 \\
\hline
\end{tabular}

Tabela 3.2: Comparação entre o resultado do SFFS e o algoritmo U-curve em nós calculados e tempo de execução para o problema de classificação biológica

lho, encontramos: (i) as fontes em $\mathrm{C}++$; (ii) o programa executável para rodar em ambiente Microsoft Windows ${ }^{\mathrm{TM}}$; (iii) os arquivos de dados utilizados nos testes apresentados e (iv) os resultados obtidos.

\subsection{Discussão}

Desevolvemos uma nova técnica para abordar os problemas de seleção de características: o algoritmo $U$-curve, que retorna elementos de custo mínimo para funções custo decomponíveis em curvas em U (com oscilações de um certo modo ou não) para cadeias maximais. Essa técnica difere das outras, como SFFS, pois ela possui um modelo formal para a estruturação do problema de seleção de características, incluindo um reticulado Booleano para o domínio, o formato de curva em U da função custo para cadeias maximais e eventuais oscilações dessas funções.

O problema de otimização é resolvido por um algoritmo estocástico do tipo branch-andbound, que explora o domínio e a função custo de estruturas particulares. A natureza Booleana do domínio permite representar o espaço de busca por uma coleção de restrições inferiores e superiores. Em cada iteração, um nó para início de cadeia é computado a partir das restrições do espaço de busca. A cadeia explorada a cada iteração é construída a partir desse nó pela escolha de nós adjacentes (superiores ou inferiores). A escolha do início da cadeia geralmente possui vários candidatos, e um deles é selecionado randomicamente. A função custo e a estrutura do domínio permitem cortes no espaço de busca, quando um mínimo local é encontrado. Após a localização de um mínimo local, todos os mínimos locais atingíveis por ele são computados pelo procedimento de esgotamento do mínimo, e os correspondentes cortes são executados. As relações de adjacência e conectividade adotadas são as do espaço de busca do diagrama de Hesse: um grafo no qual a conectividade é induzida pela relação de ordem parcial. O procedimento de esgotamento do mínimo evita que um nó seja visitado mais de uma vez e generaliza o algoritmo para funções custo decomponíveis em alguma classe de funções decomponíveis em formas de U com alguma oscilação. Os procedimentos empregados dentro do algoritmo $U$-curve são sustentados por 
resultados formais.

O algoritmo do U-curve foi aplicado para problemas práticos e comparados com o SFFS. Os experimentos foram concentrados em dois problemas: desenho de $\mathrm{W}$-operadores e redes genéticas. Para o desenho de W-operadores, os mínimos estão situados em níveis intermediários ou superiores do reticulado que representa o espaço de busca, enquanto para redes genéticas os mínimos se encontram em níveis inferiores. Em ambos problemas, os resultados médios do algoritmo $U$-curve foram melhores do que os obtidos pelo SFFS em precisão e, na maior parte das vezes, em desempenho. Os resultados do algoritmo $U$-curve considerados para comparação são compostos por uma média de várias execuções para um mesmo dado de entrada, pois, sendo ele um algoritmo estocástico, ele pode ter diferentes desempenhos para cada execução.

A eficiência do algoritmo $U$-curve depende da posição relativa dos mínimos locais no espaço de busca. O algoritmo é mais eficiente quando os mínimos locais estão próximos às extremidades do espaço de busca. A maior ineficiência é verificada quando os mínimos locais estão próximos ao meio do reticulado.

Os resultados obtidos até o momento são encorajadores, mas a presente versão do algoritmo U-curve não é uma solução rápida para problemas de dimensões altas com mínimos locais presentes no meio do reticulado que representa o espaço de busca. Para uma abordagem eficiente desses problemas, a solução da otimização $U$-curve proporciona alguns novos tópicos a serem estudados em pesquisas futuras: desenvolvimento de novos cortes à formulação branch-andbound; desenho e estimação das distribuições dos parâmetros randômicos utilizados na seleção do início de cadeias ou elementos adjacentes para sua construção, com o objetivo de atingir os mínimos com menos processamento; construir versões paralelizáveis do algoritmo; analizar possíveis erros cometidos pela técnica $U$-curve nos problemas de seleção de características, devido à parcial aderência às hipóteses do U-curve; e outros.

Com tudo isso, a técnica de otimização do $U$-curve constitui um novo framework para o estudo de problemas de seleção de características. 


\section{Capítulo 4}

\section{O pipeline de algoritmos}

Utilizando o conceito de PGNs para modelar redes genéticas, desenvolvemos, aqui, um novo pipeline de algoritmos para construir redes genéticas. Os dados de entrada são baseados em experimentos de série-temporal de microarray. O método é iniciado com genes-sementes, os quais compartilham algumas características comuns, e procura sobre o banco de dados completo os genes melhores preditos por um subconjunto dos genes-sementes para o próximo período de tempo. O processo pode ser executado um certo número de iterações, obtendo, desse modo, um grafo representando a rede. Uma tabela de predição pode ser obtida para cada nó da rede, indicando a relação existente entre os genes.

Nosso método é uma solução robusta na modelagem de redes genéticas, utilizando dados temporais de expressão gênica. O grafo obtido é uma excelente ferramenta para o pesquisador investigar a rede em questão. Com o desenvolvimento de novas técnicas para a obtenção de dados temporais, as redes construídas podem ser mais representativas e úteis para estudos futuros. Nosso método possui, também, um forte suporte matemático em comparação com os métodos existentes, ou seja, a partir de um simples experimento de série-temporal de microarray, conseguimos reproduzir a "melhor" rede possível, se considerarmos que apenas os sinais temporais são conhecidos. O suporte matemático vêm de conceitos já conhecidos na área de Reconhecimento de Padrões, tais como entropia e seleção de características. Sendo assim, a rede obtida pelo nosso pipeline é uma representação bem característica do experimento de entrada e serve de ferramenta para possíveis estudos futuros.

Na próxima Seção serão apresentados os detalhes do processo completo e algumas alternativas para ele. Um exemplo da aplicação e seus resultados também serão apresentados. Para esse exemplo, os dados de entrada são: um experimento série-temporal de microarray de resposta ao estrógeno em cultura de células T-47D [26] tratada com estrógeno (E2) durante 24 horas. Um subgrupo de genes regulados pelo estrógeno é selecionada para iniciar a rede. A saída é composta por um grafo representando a interação entre os genes e seus preditores, assim como suas tabelas de predição. 


\subsection{Descrição do método}

A motivação deste trabalho é desenvolver uma ferramenta útil que pode modelar uma rede genética a partir de um experimento específico de série-temporal de microarrays. A Figura 4.1 mostra o esquema da representação do pipeline:

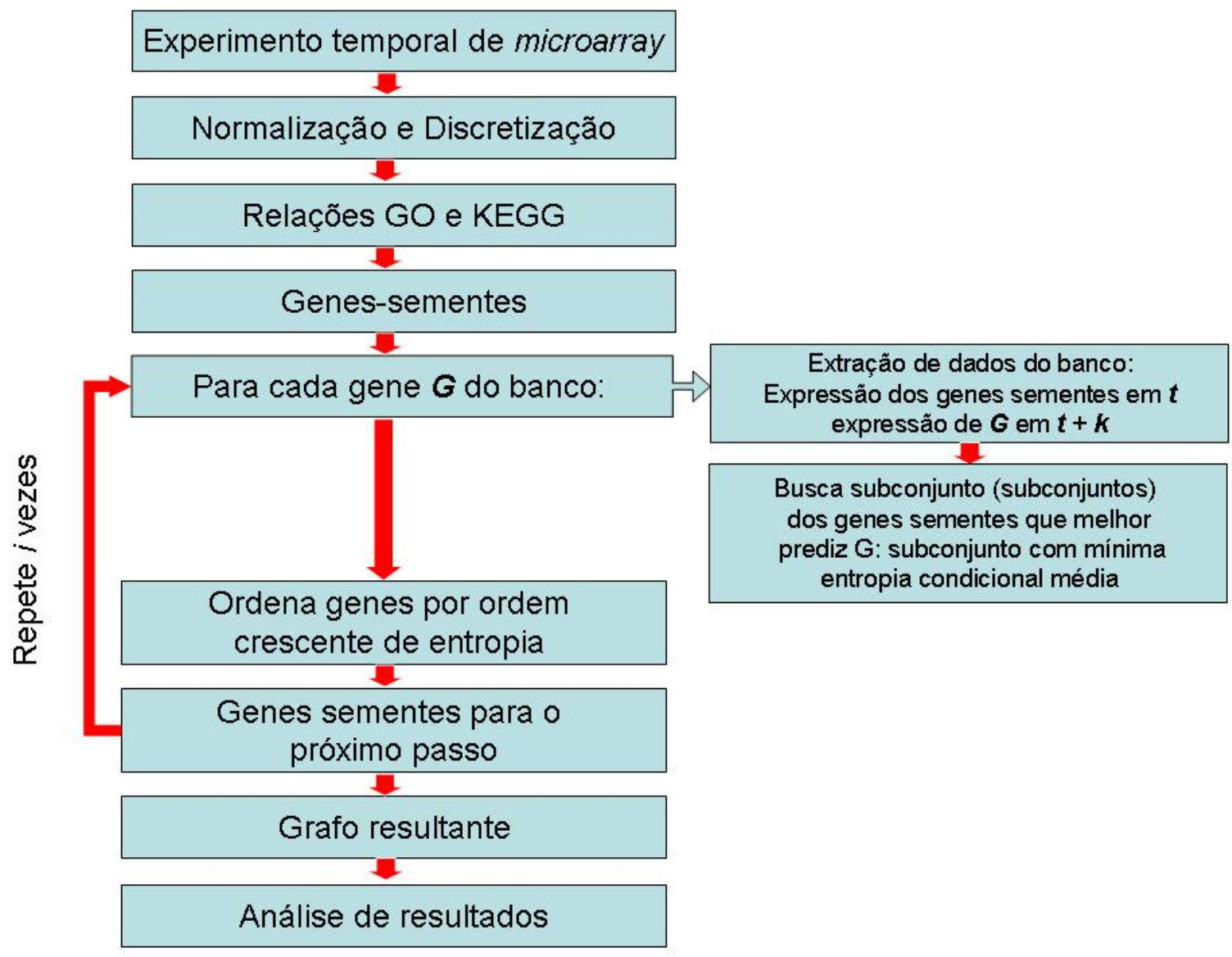

Figura 4.1: Representação esquemática do pipeline de algoritmos

1. A entrada é composta por uma série-temporal de microarray: ela pode ser vista como uma matriz $n \times m$, medindo-se o sinal de expressão de uma coleção fixa de $n$ genes (geralmente, $n>10.000$ ) durante $m$ instantes (geralmente, a cada hora, durante 24 horas) para uma cultura celular ou tecido de algum organismo, submetido a uma condição específica. Cada experimento da série é comparado com um sinal de controle (logarítmo da razão). O sinal de controle é obtido, geralmente, a partir do mesmo experimento (mesma cultura celular ou tecido) submetido a condições normais $[24,15]$. O número resultante no experimento é um número real: positivo se o gene na condição específica é mais expressso do que nas normais, negativo se menos expresso e próximo de 0 se igual às normais. Algumas vezes, uma expressão não pode ser medida por algum motivo (por exemplo: um sinal com ruídos), e para essas entradas o valor numérico é indefinido. 
2. O pipeline requer uma entrada discretizada e, para isso, a matriz $n \times m$ de números reais deve ser normalizada e discretizada. A normalização é excutada para transformar o sinal temporal ( $m$ instantes) em um sinal com distribuição normal, com média (esperança) igual a 0 e desvio padrão igual a 1. A discretização transforma o sinal de números reais em valores discretos (inteiros), por exemplo, $\{-1,0,+1\}$, com -1 , indicando sub-expressão; 0 , expressão normal, e +1 , super-expressão.

3. O experimento de microarray contém um grande número de genes, sendo que alguns deles possuem funções biológicas indefinidas (não conhecidas). Identificar funções biológicas dos genes contidos no experimento é desejável para o processo como um todo. Muitos estudos têm produzido procedimentos de classificação para padronizar as funções biológicas dos genes, tais como: o Gene Ontology Consortium [2] e o banco de dados KEGG [29]. Enquanto a ontologia gênica relaciona um gene com os processos biológicos aos quais ele está envolvido, o banco KEGG relaciona um gene com uma via de regulação. Um processo para relacionar cada um dos $n$ genes com suas ontologias e vias de regulação KEGG é processado procurando-se cada um dos genes (ou seus aliases) em cada um dos bancos (Gene Ontology e KEGG).

4. O pipeline é iniciado com um subconjunto dos $n$ genes, denominado de genes-sementes, que compartilham alguma característica comum. O tipo de experimento é a base para a seleção desse subconjunto. Em experimentos, por exemplo, onde o efeito de algum hormônio sobre a célula é testado, um bom candidato para genes-sementes são os genes regulados diretamente por esse hormônio, isto é, genes cuja expressão é afetada nos primeiros momentos quando da presença do hormônio. A ontologia ou, também, as vias KEGG podem ser usadas para restringir a seleção dos genes-sementes. Esses genes serão o ponto de início da rede resultante ao final do pipeline.

5. Para cada gene $G$ dos $n$ genes da matriz $M$ :

- Uma sub-matriz $(m-k) \times(s+1)$ contendo a expressão dos correntes $s$ genes-sementes nos instantes $t(t=1, \ldots, m-k)$ e a expressão do gene $G$ nos instantes $t+k$ $(t=1, \ldots, m-k)$ é extraído de $M$. Note que $k$ é qualquer número positivo menor que $m$, e ele pode ser ajustado de maneira a refletir o processo biológico, isto é, o tempo que uma mudança na expressão de um gene requer para afetar a expressão de outro gene.

- O subconjunto (ou subconjuntos) dos genes-sementes atuais que melhor predizem o gene $G$ é procurado entre todo o espaço de subconjuntos possíveis. Esse processo pode ser visto como um problema de seleção de características na área de Reconhecimento de Padrões, e é equivalente a buscar o subconjunto (ou subconjuntos) de menor entropia condicional média [22]. O subconjunto (ou subconjuntos) encontrado(s), seus valores de entropia associados e suas tabelas de predições são armazenadas no banco de dados para cada gene $G$. Os valores de entropia que relacionam o gene $G$ ao subconjunto preditor serão denominados de custo do gene $G$.

6. Os $n$ genes são, então, ordenados por seu custo de modo crescente (ranking). Os primeiros genes na ordenação são os melhores preditos pelo conjunto de genes-sementes atual, isto é, o subconjuto dos genes-sementes atuais tem um valor baixo para entropia condicional média. 
7. Um novo subconjunto de genes-sementes é escolhido dentre os genes no topo da ordenação (genes de menor custo). Para essa seleção pode ser aplicada as restrições semelhantes das usadas para selecionar o conjunto inicial.

8. O processo pode ser iterado $i$ vezes.

9. Para cada iteração, um conjunto de genes (genes-sementes) atua como entrada, e a saída é composta por um conjuto de genes preditos com seus subconjuntos de preditores. A partir desses dados, um grafo, como o da Figura 2.2, pode ser contruído.

10. Todos os dados resultantes podem ser analizados: simulação, validação, comprovação ds relações em bancada, entre outros.

\subsection{Normalização e discretização}

O pipeline requer que as expresssões sejam valores discretos em vez de números reais contidos na matriz que representa o experimento de série-temporal de microarray. Existem vários métodos para a tranformação de números reais em valores discretos. Seja $M$ a matriz resultante $n \times m$ do experimento de série-temporal de microarray. O método baseado em [3] foi implementado. Ele se baseia em duas etapas:

- Normalização da matriz $M$ para a matriz $M_{N}$. Esse processo consiste em normalizar o sinal de cada gene em um sinal com distribuição normal de média (esperança) igual a 0 e desvio padrão igual a 1 . Com isso, todos os genes terão a mesma distribuição e suas expressões poderão ser comparadas. A normalização consiste em: (i) calcular o valor esperado $E_{i}$ e o desvio padrão $\sigma_{i}$ para o sinal de cada gene $i$ dados, respectivamente, por $E_{i}=\frac{\sum_{k=1}^{m} M[i, k]}{m}$ e $\sigma_{i}=\sqrt{\frac{\sum_{k=1}^{m}\left(M[i, k]-\mu_{i}\right)^{2}}{m-1}}$; (ii) os elementos resultantes da matriz normalizada $M_{N}$ são dados por $M_{N}[i, k]=\frac{M[i, k]-E_{i}}{\sigma_{i}}, i=1, \ldots, n$ e $k=1, \ldots, m$.

- Discretização da matriz $M_{N}$ para a matriz $M_{Q}$. Esse processo equivale a mapear os sinais normalizados de $M_{N}$ para um conjunto de níveis qualitativos de expressão. Aqui usaremos três níveis qualitativos de expressão $\{-1,0,+1\}$, indicando, respectivamente: sub-expresso, nulo, e sobre-expresso em relação ao valor de referência. O mapeamento para a quantização foi feito usando-se dois limitantes como em [3]. Para cada gene $i$, um limitante inferior $l_{i}$ e outro superior $u_{i}$ foram calculados, respectivamente, por:

$$
\begin{aligned}
l_{i} & =\frac{\sum_{M_{N}[i, k]<0} M_{N}[i, k]}{\left|\left\{M_{N}[i, k]: M_{N}[i, k]<0\right\}\right|} \\
u_{i} & =\frac{\sum_{M_{N}[i, k]>0} M_{N}[i, k]}{\left|\left\{M_{N}[i, k]: M_{N}[i, k]>0\right\}\right|}
\end{aligned}
$$

Em outras palavras, $l_{i}$ e $u_{i}$ são, respectivamente, o valor esperado dos sinais negativos e dos positivos. Os elementos da matriz quantizada $M_{Q}$ são dados por: 


$$
M_{Q}[i, k]= \begin{cases}-1 & \text { se } M_{N}[i, k]<l_{i} \\ 0 & \text { se } M_{N}[i, k]>=l_{i} \text { and } M_{N}[i, k]>=l_{i} \\ +l & \text { se } M_{N}[i, k]>=u_{i}\end{cases}
$$

para $i=1, \ldots, n$ e $k=1, \ldots, m$.

O número de limitantes deve ser incrementado quando a discretização for composta por mais de três níveis. Por exemplo, se os níveis de discretização são $\{-2,-1,0,+1,+2\}$, os valores -2 e +2 podem, respectivamente, ser associados aos limitantes $2 \times l_{i}$ e $2 \times u_{i}$. O número de níveis de discretização pode ser determinado pelo número de amostras (instantes) que o experimento de série-temporal possui. Para valores pequenos de amostras $(m)$, um número superior a três níveis de discretização, geralmente, não produz bons resultados, isto é, poucas amostras para um número grande de possíveis estados.

Algumas entradas (genes) do experimento de série-temporal devem ser filtradas. A razão para isso pode estar em um dos dois casos: (i) o sinal da expressão não pode ser determinado, ou (ii) a expressão do gene é constante ao longo de todo experimeento, isto é, seu valor se mantém igual a $-1,0$ ou +1 durante todos os instantes $(1$ a $m$ ). Para o primeiro caso, simplesmente atribuímos o valor nulo para a entrada $\left(M_{Q}[i, k]=\right.$ nulo). Para o segundo caso, os genes com expressões constantes podem ser preditos por quaisquer combinações de outros genes, ou seja, a entropia condicional média sempre vale 0, dado qualquer subconjunto de preditores. Sendo assim, esses genes não agregam nenhuma nova informação à rede resultante e, por essa razão, eles devem ser removidos do banco de dados inicial.

\subsubsection{Análise do conjunto de genes-sementes}

A cada passo o pipeline requer um conjunto de genes, denominado de genes-sementes. Esse conjunto é formado pelos possíveis preditores a serem encontrados para cada um dos genes contidos no banco de dados completo do experimento. Existem diversas possibilidades na definição do método de seleção dos genes-sementes. A rede resultante do pipeline é uma rede dependente do tempo (Figura 2.2) e, para a seleção dos genes que iniciarão a rede, seria conveniente que estes compartilhassem alguma característica comum. Experimentos nos quais, a regulação de algum fator biológico é testada, um bom candidato para o conjunto de genes-sementes iniciais pode ser formado pelo genes regulados diretamente pelo fator biológico. O termo "regulado diretamente" por um fator biológico significa que o fator biológico participa diretamente na regulação da expressão do gene, em outras palavras, o fator biológico é um fator de transcrição do gene. Por exemplo, para células tratadas com estrógeno para testar sua rede de regulação, um bom candidato para o conjunto de genes-sementes pode ser os genes regulados diretamente pelo estrógeno, isto é, genes onde o estrógeno atua como fator de transcrição. Esses genes podem ser obtidos em estudos prévios ou a partir de métodos de agrupamento (clustering). Os genes-sementes para os passos subseqüentes serão compostos pelos genes melhores preditos pelo conjunto de genes-sementes do passo anterior. Um subconjunto $\mathcal{A}$ dos genes-sementes prediz a expressão do gene $A$ no instante seguinte melhor do que um subconjunto $\mathcal{B}$ prediz o gene $B$, se a tabela de predição que associa $\mathcal{A}$ para $A$ é mais determinística que a que associa $\mathcal{B}$ para $B$. Em outras palavras, o vetor de expressões $\mathbf{A}$ dos genes em $\mathcal{A}$ determina a expressão do gene $A$ no próximo instante com menos erro que os genes em $\mathcal{B}$ determinam a expressão do gene $B$. 
O tamanho do conjunto de genes-sementes ideal para o problema, também, pode ser função do tamanho $m$ do experimento. Quanto maior o número $m$, maior será o subconjunto de predição obtido, pois os erros de estimação associados aos subconjuntos serão relevantes apenas para subconjuntos com tamanhos superiores. Em nossos testes, utilizamos conjuntos de genessemente da ordem de 30 elementos para um experimento da ordem de $m=15$.

\subsubsection{Função custo}

Para cada gene, denominado de gene-alvo, do banco de dados e um dado conjunto de genessementes, tentamos encontrar, entre todos os subconjuntos possíveis, aquele que melhor prediz a expressão do gene-alvo em questão. Erro de classificação é um conceito matemático que pode ser aplicado para medir o quanto uma variável aleatória $A$ é determinada dado um vetor aleatório $\mathbf{A}$. Se o erro de classificação de $A$ dado $\mathbf{A}$ é pequeno, dizemos que $A$ é bem determinado por $\mathbf{A}$; e se o erro de classificação é grande, dizemos que $A$ é mal determinado por A. Para nosso problema, a variável aleatória $A$ representa a expressão do gene-alvo no instante $t$, e o vetor aleatório A representa a expressão de um conjunto de genes em $t-k$. Existem inúmeras maneiras de estimar o erro de classificação: MAE (erro absoluto médio), entropia condicional média [22], CoD (coeficiente de determinação) [8, 16] e Bolstered Error [5, 38] são alguns exemplos deles. Enquanto as medidas de erro MAE, CoD e Bolstered indicam a probabilidade média da classificação incorreta, a entropia condicional média é uma medida inversamente proporcional à quantidade de informação obtida para a classificação dado o subconjunto de entrada. Todas essas medidas possuem valores pequenos se o subconjunto de entrada conduz a bons resultados de classificação; no nosso caso, se ele é um bom preditor do gene-alvo.

Em nossos testes, usamos a entropia condicional média como função custo. A entropia mede a dispersão de uma função de distribuição de probabilidade, isto é, a entropia possui valores pequenos para distribuições com massa concentrada em um dos valores possíveis, e possui o maior valor para uma distribuição uniforme. A Figura 4.2 mostra três exemplos de funções de distribuição de probabilidades para uma variável aleatória discreta com três níveis de discretização: -1, 0 e 1. A entropia máxima ocorre para a varáivel aleatória $Y$ (distribuição uniforme), e as entropias das variáveis $Y^{\prime}$ e $Y^{\prime \prime}$ são equivalentes e com valores pequenos, já que suas massas estão concentradas em um dos valores: 1 para $Y^{\prime}$ e -1 para $Y^{\prime \prime}$.

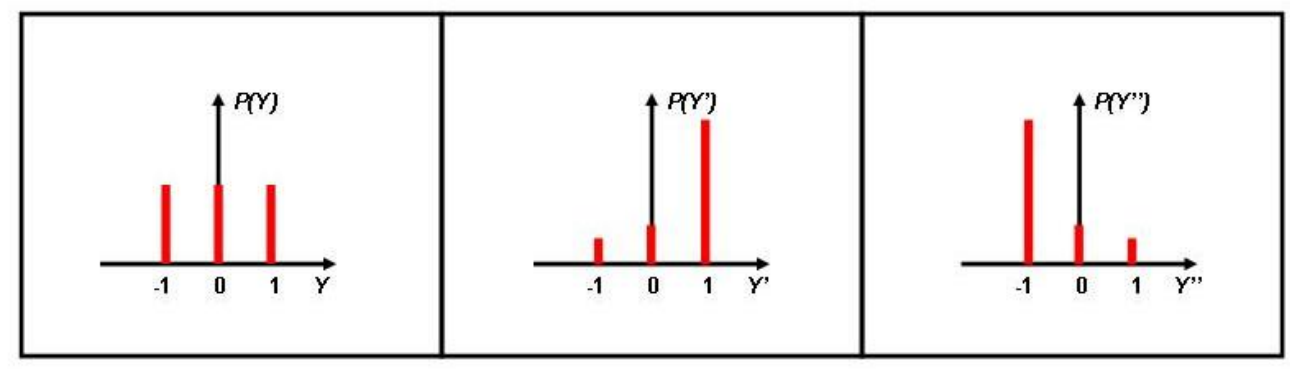

Figura 4.2: Três exemplos de funções distribuição de probabilidades para uma variável aleatória discreta com três níveis de discretização 
Em nosso estudo estamos interessados na probabilidade de uma variável aleatória discreta $G$, que representa a expressão do gene-alvo, dado um vetor aleatório discreto A representando a expressão de um subconjunto dos genes-sementes. Essa probabilidade é denotada por $P_{G \mid \mathbf{A}}$. Seja $\mathcal{Q}$ o conjunto de valores discretos usados para diferenciar as expressões dos genes, por exemplo, $\mathcal{Q}=\{-1,0,+1\}$. A entropia condicional média $E[H(G \mid \mathcal{A})]$ é dada por:

$$
E[H(G \mid \mathbf{A})]=\sum_{\mathbf{a} \in \mathcal{Q}^{|\mathbf{A}|}} P_{\mathbf{A}}(\mathbf{A}=\mathbf{a})\left(-\sum_{g \in \mathcal{Q}} P_{G \mid \mathbf{A}}(G=g \mid \mathbf{A}=\mathbf{a}) \log _{|\mathcal{Q}|} P_{G \mid \mathbf{A}}(G=g \mid \mathbf{A}=\mathbf{a})\right)
$$

Baseando-se apenas nos dados de entrada, podemos simplesmente calcular uma estimativa da função custo, e não o seu valor real. A entropia condicional média estimada $\hat{E}[H(G \mid \mathcal{A})]$ é dada por:

$$
\hat{E}[H(G \mid \mathbf{A})]=\sum_{\mathbf{a} \in \mathcal{Q}^{|\mathbf{A}|}} \hat{P}_{\mathbf{A}}(\mathbf{A}=\mathbf{a})\left(-\sum_{g \in \mathcal{Q}} \hat{P}_{G \mid \mathbf{A}}(G=g \mid \mathbf{A}=\mathbf{a}) \log _{|\mathcal{Q}|} \hat{P}_{G \mid \mathcal{A}}(G=g \mid \mathbf{A}=\mathbf{a})\right)
$$

A equação (4.4) requer a estimativa de $P_{\mathbf{A}}$ e $P_{G \mid \mathbf{A}}$. Existem vários estimadores possíveis para essas medidas. Para o nosso trabalho, adotaremos os mesmos estimadores em [3]. Seja $f$ um número inteiro, denominado de freqüência limitante, usado para separar instâncias a do vetor aleatório $\mathbf{A}$ que ocorrem com pouca freqüência. Seja $N^{+}$a soma das freqüências das instâncias a de $\mathbf{A}$ que ocorrem um número de vezes maior ou igual a $f$ nas amostras, e $N^{-}$a soma das freqüências das instâncias a de $\mathbf{A}$ que ocorrem menos do que $f$ vezes nas amostras. Isto equivale a:

$$
\begin{aligned}
& N^{+}=\sum_{\#(\mathbf{A}=\mathbf{a}) \geq f, \forall \mathbf{a} \in \mathcal{Q}^{|\mathbf{A}|}} \#(\mathbf{A}=\mathbf{a}) \\
& N^{-}=\sum_{\#(\mathbf{A}=\mathbf{a})<f, \forall \mathbf{a} \in \mathcal{Q}^{|\mathbf{A}|}} \#(\mathbf{A}=\mathbf{a})
\end{aligned}
$$

Seja $\mathbf{a} \in \mathcal{Q}^{|\mathbf{A}|}$ uma instância de $\mathbf{A}$, e $g \in \mathcal{Q}$ uma instância de $G$, o estimador $\hat{P}_{G \mid \mathbf{A}}$ de $P_{G \mid \mathbf{A}}$ é dado por:

$$
\hat{P}_{G \mid \mathbf{A}}(G=g \mid \mathbf{A}=\mathbf{a})= \begin{cases}\frac{\#(G=g \wedge \mathbf{A}=\mathbf{a})}{\#(\mathbf{A}=\mathbf{a})}, & \text { se } \#(\mathbf{A}=\mathbf{a}) \geq f \\ \frac{\#(G=g)}{N^{+}+N^{-}} & \text {se } \#(\mathbf{A}=\mathbf{a}),<f\end{cases}
$$

e o estimador $\hat{P}_{\mathbf{A}}$ de $P_{\mathbf{A}}$ dado por:

$$
\hat{P}_{\mathbf{A}}(\mathbf{A}=\mathbf{a})= \begin{cases}\frac{N^{+}}{N^{+}+N^{-}} \times \frac{\#(\mathbf{A}=\mathbf{a})}{N^{+}}, & \text {se } \#(\mathbf{A}=\mathbf{a}) \geq f \\ \frac{N^{-}}{N^{+}+N^{-}} \times \frac{1}{2^{|\mathbf{A}|}-\left|\left\{\mathbf{a}^{\prime} \in \mathcal{Q}^{|\mathbf{A}|}: \#\left(\mathbf{A}=\mathbf{a}^{\prime} \geq f\right)\right\}\right|}, & \text { se } \#(\mathbf{A}=\mathbf{a}) \geq f\end{cases}
$$

O estimador $\hat{P}_{\mathbf{A}}$ distribui uniformemente a freqüência $N^{-}$entre todas as instâncias que não ocorrem ou ocorrem menos que $f$ vezes. A Figura 4.3 mostra graficamente a representação do estimador $\hat{P}_{\mathbf{A}}$. 


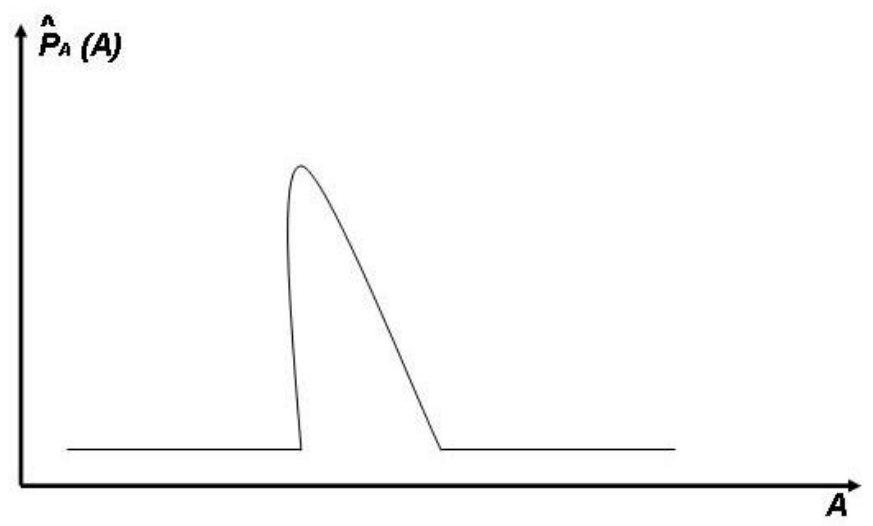

Figura 4.3: Representação gráfica do estimador $\hat{P}_{\mathbf{A}}$ de uma função distribuição de probabilidade para um vetor de expressões $\mathbf{A}$

\subsubsection{Melhor subconjunto preditor}

O problema de encontrar o melhor subconjunto de predição (subconjunto de menor custo) entre a família de subconjuntos de um dado conjunto é um problema combinatório de grande complexidade (exponencial). Seja $\mathcal{S}$ o conjunto de genes-sementes usados para predizer a expressão de um gene $G$. O número de possíveis subconjuntos de $\mathcal{S}$ é exponencial $\left(2^{|\mathcal{S}|}\right)$, e para grandes valores de $|\mathcal{S}|$, a busca completa se torna impraticável. Esse problema pode ser estudado como um problema de seleção de características no contexto de Reconhecimentos de Padrão [9, 19]. Algumas heurísticas foram desenvolvidas para lidar com esses tipos de problema. Elas exploram o espaço de possibilidades sem ser equivalente a busca completa, isto é, elas não garantem encontrar o melhor subconjunto (menor custo). Podemos exemplificar com algumas heurísticas de relativo sucesso empregadas: SFS (Sequential Forward Selection), SBS (Sequential Backward Selection), SFFS (Sequential Floating Backward Selection) e SFFS (Sequential Floating Forward Selection) [32].

O espaço de busca pode ser organizado por um reticulado Booleano completo de ordem $|\mathcal{S}|$, no qual cada elemento representa um subconjunto de $\mathcal{S}$. A Figura 4.4 mostra um reticulado Booleano completo de ordem 4 . Seja $\mathcal{S}=\left\{G_{1}, G_{2}, G_{3}, G_{4}\right\}$, o elemento 1010 do reticulado Booleano representa o subconjunto $\left\{G_{1}, G_{3}\right\}$ de $\mathcal{S}$, isto é, 1 ou 0 na posição $k$ indica, respectivamente, que o gene $G_{k}$ está ou não está contido no subconjunto representado pelo elemento. Além disso, cada elemento do reticulado Booleano possui um valor para a função custo associado ao subconjunto representado por ele. O elemento 0111 (verde) representa o subconjunto de mínimo custo (5). Uma característica importante desse problema é que a função custo restrita a qualquer cadeia do reticulado Booleano tem o formato de curva em U. Uma cadeia (0000, 0100, 0110, 1110, 1111) é enfatizada (vermelho) na Figura 4.4, e podemos ver a curva em U formada pelo custo restrito à ela $(9,7,6,10,11)$. Essa característica pode ser usada para desenvolver soluções do tipo branch-and-bound. Um exemplo é o algoritmo U-curve [33], o qual se equivale à busca completa sem visitar o espaço total. Isso ocorre pela remoção de subespaços (posets) do espaço 
de busca, a cada momento em que um elemento de custo mínimo é encontrado na cadeia. Na Seção 3, o algoritmo $U$-curve é apresentado em detalhes.

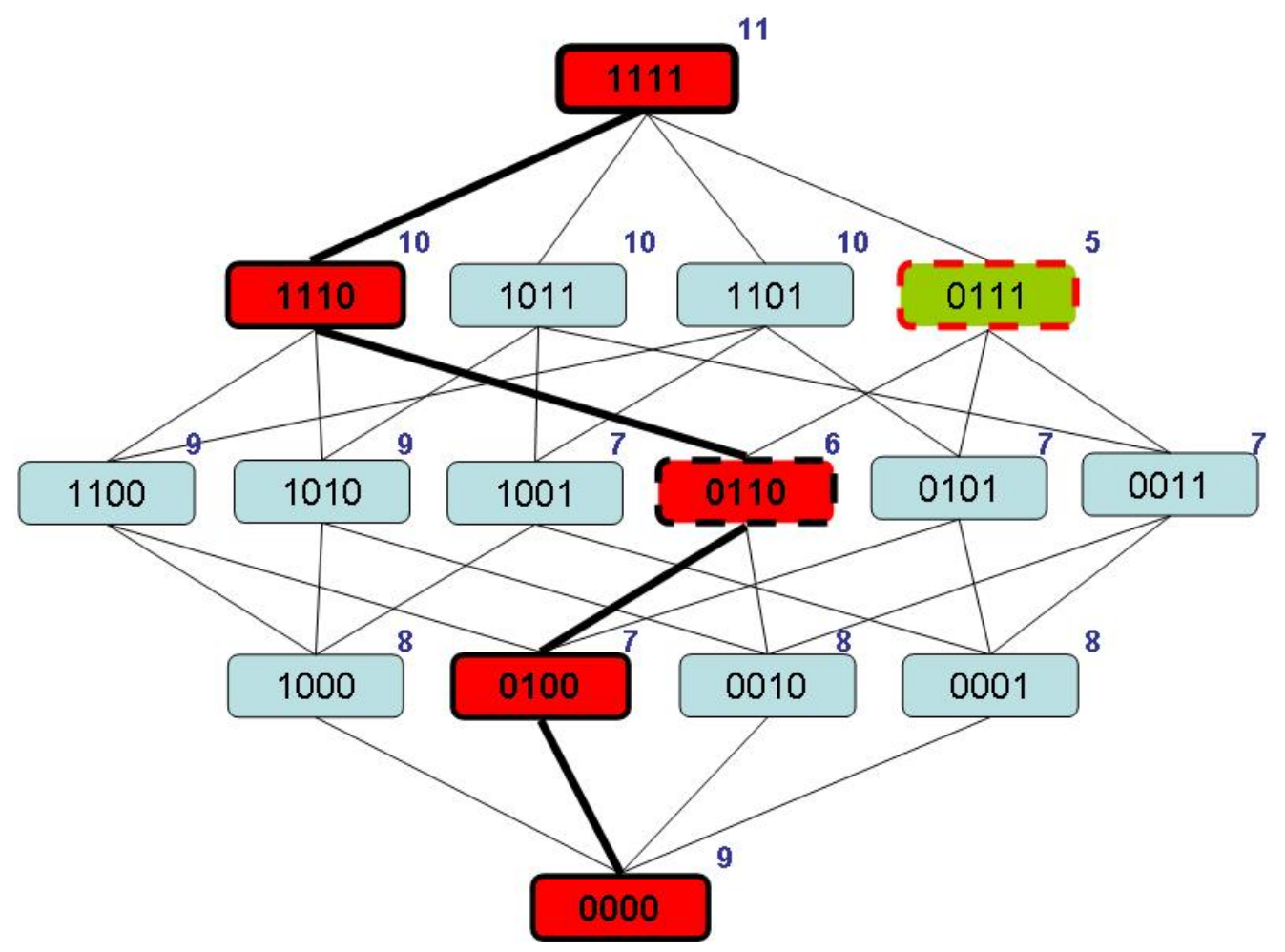

Figura 4.4: Representação de um reticulado Booleano de ordem 4 e a função custo associada a cada um de seus elementos

A cardinalidade do subconjuto de custo mínimo está relacionada à cardinalidade $|\mathcal{S}|$ do conjunto $\mathcal{S}$ e ao tamanho $m$ do experimento (amostras) usado para estimar a função custo. O custo de um subconjunto é formado em parte pelo erro de classificação real e parte pelo erro de estimação. Quando $m$ é pequeno e $|\mathcal{S}|$ é grande, os subconjuntos de $\mathcal{S}$ com mínimo custo tendem a ter poucos componentes em comparação ao conjunto inteiro $\mathcal{S}$. Observando o reticulado Booleano (Figura 4.4), esses subconjuntos estarão mais perto da base (elemento 0000) do que do topo (elemento 1111). Para esses casos, uma busca exaustiva limitada a um tamanho de subconjunto definido pode ser executada. Por exemplo, limitar a busca a subconjuntos de tamanho 3 reduz o espaço de busca para um tamanho de $\left(\begin{array}{c}|\mathcal{S}| \\ 0\end{array}\right)+\left(\begin{array}{c}|\mathcal{S}| \\ 1\end{array}\right)+\left(\begin{array}{c}|\mathcal{S}| \\ 2\end{array}\right)+\left(\begin{array}{c}|\mathcal{S}| \\ 3\end{array}\right)$ elementos.

O subconjuto de menor custo nem sempre representa o melhor subconjunto a ser considerado. Isso pode acontecer, pois experimentos com poucas amostras tornam o erro de estimação como a principal componente da função custo e, sendo assim, subconjuntos com custos próximos podem ser bons candidatos ao melhor subconjunto de preditores. O método usado para encontrar o 
melhor subconjunto preditor pode retornar não somente o melhor, mas, sim, uma lista dos melhores subconjutos encontrados, ordenados pelos seus respectivos custos. Essa lista pode fornecer ao pesquisador uma variedade maior de subconjuntos a serem analisados.

As Tabelas 4.1 e 4.2 mostram dois exemplos de tabelas de predições e suas funções funções custos: entropia condicional média com freqüência limitante $f=1$. A primeira coluna das tabelas mostra a freqüência da ocorrência de cada uma das configurações dos genes do subconjunto (TBX21,FRAT2) em um experimento de série-temporal de microarray com 15 instantes. Podese notar que na Tabela 4.1 a expressão do gene-alvo TGFBP3 é quase sempre determinada ( 5 de 6 vezes) pela expressão dos genes TBX21 e FRAT2; já na Tabela 4.2 a expressão do gene-alvo TNFSF8 é determinada um número menor de vezes (4 de 6 vezes) pelos genes POU1F1 e EPAS1. Com isso, o custo associado à Tabela 4.1 (0,066667) é menor em comparação ao associado à Tabela $4.2(0,217674)$.

\begin{tabular}{|c|c|c|c|c|c|}
\hline \multicolumn{2}{|c|}{ Subconjunto dos genes-sementes } & \multicolumn{3}{|c|}{ TGFBP3 } \\
\hline Freqüência & TBX21 & FRAT2 & $\mathbf{- 1}$ & $\mathbf{0}$ & $+\mathbf{1}$ \\
\hline 2 & -1 & -1 & $0,00 \%$ & $\mathbf{1 0 0 , 0 0 \%}$ & $0,00 \%$ \\
\hline 3 & -1 & 0 & $\mathbf{1 0 0 . 0 0} \%$ & $0,00 \%$ & $0,00 \%$ \\
\hline 2 & 0 & -1 & $0,00 \%$ & $\mathbf{1 0 0 , 0 0 \%}$ & $0,00 \%$ \\
\hline 5 & 0 & 0 & $0,00 \%$ & $\mathbf{1 0 0 , 0 0 \%}$ & $0,00 \%$ \\
\hline 2 & 0 & 1 & $0,00 \%$ & $0,00 \%$ & $\mathbf{1 0 0 , 0 0 \%}$ \\
\hline 1 & 1 & 1 & $33,33 \%$ & $33,33 \%$ & $33,33 \%$ \\
\hline
\end{tabular}

Tabela 4.1: Exemplo de uma tabela de predição para o subconjunto de genes TBX21 e FRAT2 ao gene TGFBP3.

\begin{tabular}{|c|c|c|c|c|c|}
\hline \multicolumn{2}{|c|}{ Subconjunto dos genes-sementes } & \multicolumn{3}{|c|}{ TNFSF8 } \\
\hline Freqüência & POU1F1 & EPAS1 & $\mathbf{- 1}$ & $\mathbf{0}$ & $\mathbf{+ 1}$ \\
\hline 2 & -1 & 0 & $0,00 \%$ & $\mathbf{1 0 0 , 0 0 \%}$ & $0,00 \%$ \\
\hline 4 & 0 & -1 & $0,00 \%$ & $75,00 \%$ & $25,00 \%$ \\
\hline 3 & 0 & 0 & $0,00 \%$ & $\mathbf{1 0 0 , 0 0 \%}$ & $0,00 \%$ \\
\hline 2 & 0 & 1 & $0,00 \%$ & $\mathbf{1 0 0 , 0 0 \%}$ & $0,00 \%$ \\
\hline 1 & 1 & 0 & $33,33 \%$ & $33,33 \%$ & $33,33 \%$ \\
\hline 3 & 1 & 1 & $\mathbf{1 0 0 , 0 0} \%$ & $0,00 \%$ & $0,00 \%$ \\
\hline
\end{tabular}

Tabela 4.2: Exemplo de uma tabela de predição para o subconjunto de genes POU1F1 e EPAS1 ao gene TNFSF8.

\subsubsection{Ordenação dos resultados ("ranking")}

O melhor subconjuto preditor dos genes-sementes e o custo associados a cada um dos genes do banco de dados são armazenados ao longo do processo. Dizemos que um gene $G$ é melhor predito que um gene $G^{\prime}$ pelo conjunto de genes-sementes se o custo do melhor subconjunto de preditores 
dos genes-sementes para $G$ é menor que o custo do melhor subconjunto para $G^{\prime}$. Dispor os genes do banco de dados em ordem crescente do custo associado aos seus melhores subconjuntos de predição produz uma lista em que os elementos iniciais são os genes melhores preditos pelos genes-sementes no próximo instante $k$. Esse é o procedimento principal na obtenção de uma nova lista de genes-sementes para o próximo passo do pipeline. Muitos métodos podem ser empregados para extrair o próximo conjunto de genes-sementes. Apresentamos, aqui, alguns deles:

- Definir de um valor $s$ limitante para a função custo, isto é, extrair os genes com melhor subconjunto de preditores de custo menor que $s$. Esse valor limitante pode ser alterado a cada iteração, dependendo do número de genes extraídos por esse valor. À medida que $s$ cresce, o melhor subconjunto preditor para alguns genes se torna menos deteminístico, sendo assim, um gene com custo alto não será bem determinado pelo conjunto de genessementes, não tornando-se um bom candidato a ser incluído no próximo conjunto de genessementes.

- Extrair um número fixo de genes do topo da lista de ordenação que possuem alguma função biológica em comum (GO e/ou KEGG). Por exemplo, extrair os primeiros 30 genes que possuem uma das funções biológicas: divisão celular, proliferação celular e/ou ciclo celular.

- A partir de uma dada lista inicial de genes, extrair um número fixo de genes do topo da ordenação que pertence a lista.

Esses métodos podem ser agrupados para a obtenção do próximo conjunto de genes-sementes. Por exemplo, escolher um valor limitante $s$ e uma série de funções biológicas para extrair um conjunto de genes-sementes que possuem melhor subconjunto preditor com custo menor que $s$ e compartilham essas mesmas funções biológicas.

\subsubsection{Resultados experimentais}

A entrada para os resultados experimentais foi obtida a partir de um experimento de sérietemporal de microarray (Compugen 19K human oligonucleotide array) de células T-47D, tratadas com estrógeno (E2) [26], com 16 experimentos, durante 24 horas. Alguns dos genes foram removidos do processo completo: (i) genes não encontrados no banco de dados "Stanford MicroArray", ou (ii) genes com sinais de expressão constantes ou com a maioria (mais do que metade) dos sinais não definidos. Para os sinais não definidos, as entradas foram marcadas com valores nulos e ignoradas no processo. As vias $K E G G$ e as funções biológicas $(G O)$ foram pesquisadas e armazenadas no banco de dados para cada gene.

Todos os dados foram normalizados e discretizdos usando-se o mesmo método em [3] com três níveis de discretização $\{-1,0,+1\}$ e utilizando os limitantes $l_{i}$ e $u_{i}$, descritos nas Equações 4.1 e 4.2, para cada gene $i$.

O conjunto inicial dos genes-sementes foi obtido pela pesquisa no banco de dados dos 386 genes que possuem resposta ao estrógeno (E2) (trabalho em [26]) e que contêm uma das seguintes funções biológicas em suas entradas no GO: cell cycle (ciclo celular), cell proliferation (proliferação celular), DNA ou cell diferentiation (diferenciação celular). Essas funções biológicas, 
usadas como filtro para os genes-sementes iniciais, foram obtidas do trabalho em [13], como as categorias funcionais de genes estimulados ou reprimidos pelo estrógeno. Essa condição foi usada como filtro para extração dos genes-sementes para todas as iterações. O conjunto resultante inicial foi composto de 33 genes. O melhor subconjunto preditor dos genes-sementes para cada gene foi obtido usando, como função custo a entropia condicional média estimada descrita anteriormente, e a busca exaustiva limitada em um subconjunto de tamanho 3 . A submatriz $15 \times 34$ das expressões dos genes-sementes no instante $t(t=1, \ldots, 15)$ e de cada um dos genes-alvos no instante $t+1(k=1)$ foi a entrada para a busca exaustiva do melhor subconjunto preditor do gene-alvo. O conjunto dos genes-sementes, extraídos na segunda iteração, foi obtido dos genes filtrados (funções biológicas utilizados no conjunto inicial) do topo da ordenação (ranking) entre os melhores preditos pelos genes-sementes iniciais (custo $<0.13$ ), resultando em um conjunto de 38 novos genes-sementes. O mesmo processo para encontrar o melhor subconjunto preditor para esse novo conjunto de genes-sementes foi executado. O conjunto de genes-sementes para a terceira iteração foi extraído entre os genes filtrados no topo da ordenação (custo $<0.09$ ), resultando em um novo conjunto de 37 genes-sementes. Os melhores genes preditos após a terceira iteração foram, também, extraídos entre os genes filtrados no topo da ordenação (custo < 0.09), resultando em um conjunto de 38 genes-sementes.

Os resultados do processo completo foram organizados e processados para gerar um grafo representando a rede. A Figura 4.5 mostra o grafo que representa a rede obtida. As arestas direcionadas verdes, vermelhas e azuis representam, respectivamente, as primeiras, segundas e terceiras iterações.

O grafo resultante é apresentado como uma página html e, para cada nó, representando um gene, existem redirecionamentos (links) para: (i) o banco de dados "Stanford MicroArray" (Figura 4.6), relacionando o gene com seus possíveis aliases, e informações conhecidas a respeito dele; (ii) suas tabelas de predições, relacionando-o a seus melhores subconjuntos de predições (Figure 4.7); e (iii) um gráfico do sinal de expressões do gene-alvo e de seus preditores ao longo do experimento (Figura 4.8).

\subsection{Discussão}

O pipeline de algoritmos desenvolvido possui vários parâmetros a serem explorados. A simples mudança em seus valores ou nos métodos empregados para a obtenção deles podem produzir resultados diferentes. Implementamos, neste trabalho, alguns dos métodos discutidos e utilizamos alguns valores para os parâmetros, produzindo resultados que podem ser analisados pelo pesquisador em trabalhos futuros. A qualidade dos resultados e os parâmetros utilizados para sua obtenção estão extremamente relacionados com o tipo do experimento inicial de entrada. Em um experimento com poucas amostras, isto é, um experimento de série-temporal de microarray com um número pequeno de medidas, a qualidade do resultado pode ser ruim, mas, de qualquer modo, o resultado produzido é um dos melhores que podem ser obtidos a partir do experimento de entrada. Um parâmetro importante a destacar é a diferença de tempo $k$ entre o instante da expressão medida para os genes preditores e o gene-alvo predito, isto é, o período de tempo que uma mudança na expressão de um gene afeta a expressão de outro. Para um experimento de série-temporal no qual as medidas são feitas a cada hora, o valor mínimo para $k$ é 1 , mas não existe garantia formal de que esta é a melhor escolha. Outros parâmetros que podem ser 


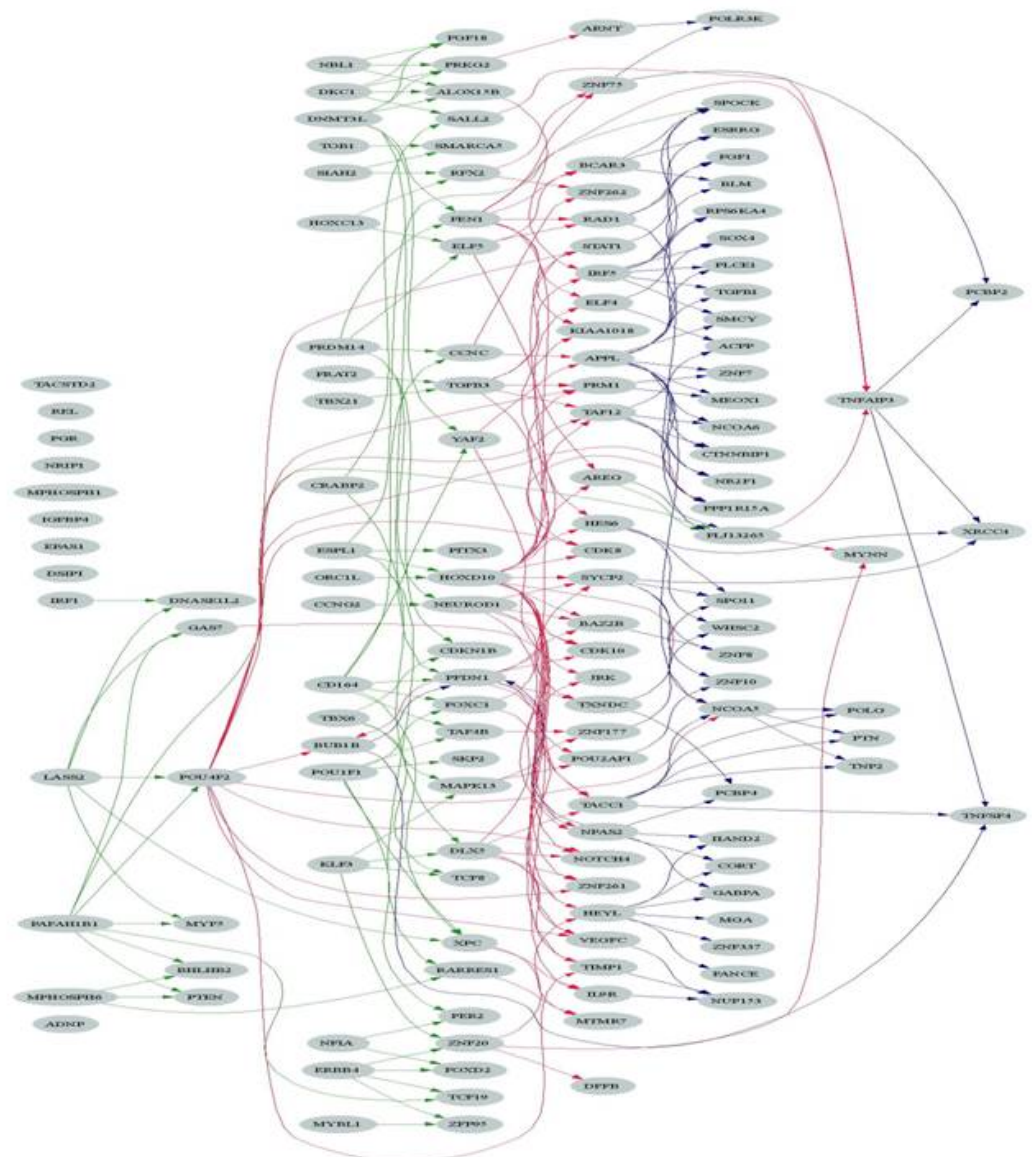

Figura 4.5: Grafo resultante obtido pela aplicação do pipeline ao experimento de série-temporal de microarray em [26] 


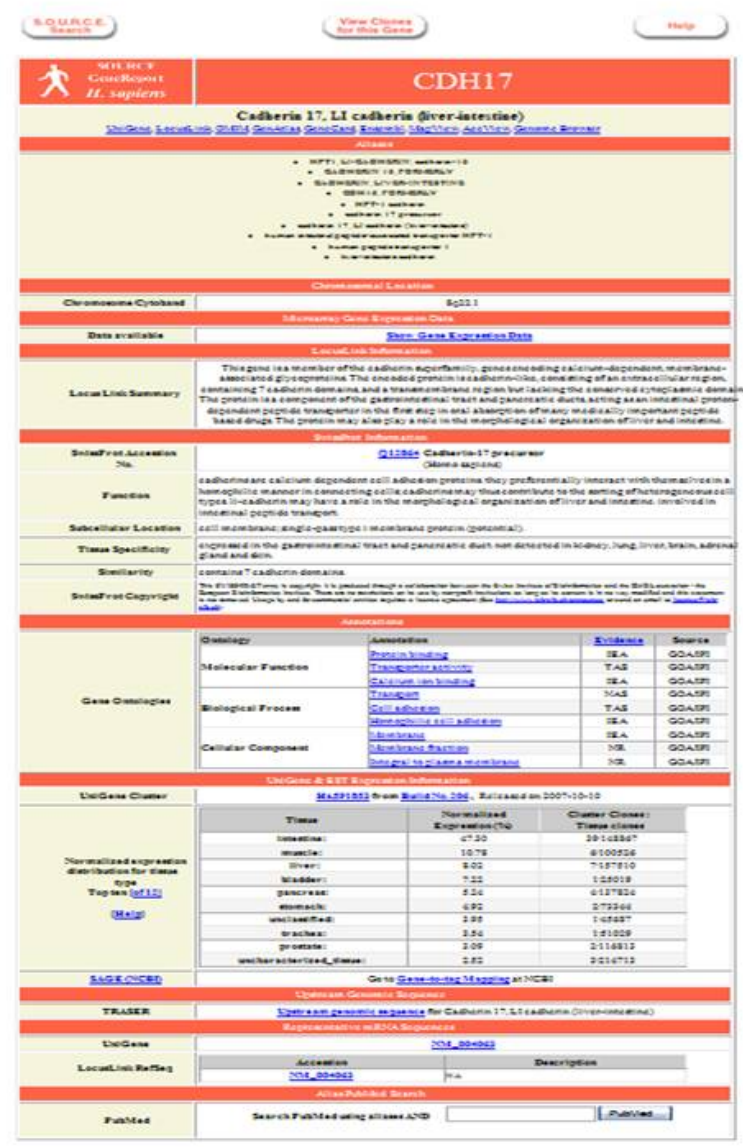

Figura 4.6: Página do banco de dados de "Stanford MicroArray" para o gene CDH17 


\begin{tabular}{|l|l|l|l|l|l|l|l|l|}
\hline $\begin{array}{l}\text { Subset Entropy: } 0.126185 \\
\text { Target Entropy: 0.826074 }\end{array}$ \\
Expression Plot: PLOT - TESTE1 STEP2 GO
\end{tabular}

Figura 4.7: Quatro exemplos de tabelas de predições como uma página $h t m l$, para uma parte da rede: gene HOXD10 com seus preditores e preditos

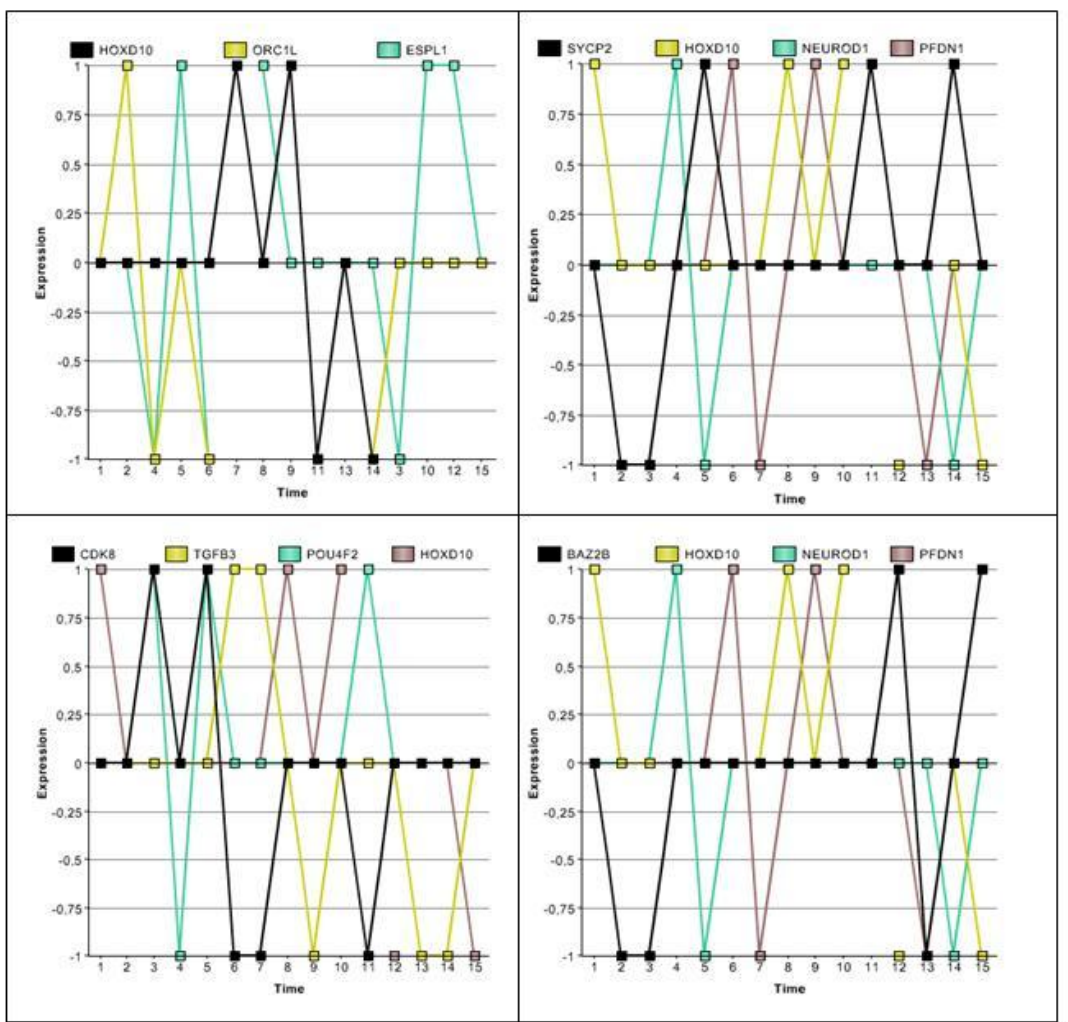

Figura 4.8: Gráficos das expressões dos genes relacionados a cada uma das quatro tabelas de predições da Figura 4.7 
analisados em trabalhos futuros são:

- métodos alternativos para filtrar os genes do banco de dados;

- normalização e discretização dos sinais de expressões dos genes;

- estimação para a função custo;

- métodos para a extração dos genes-sementes;

- algoritmos para seleção de características aplicada a seleção de melhor conjunto preditor.

A rede produzida pelo processo completo pode também ser simulada e testada em comparação com dados reais. Isso pode ser feito a partir da entrada de uma configuração dada para os genes-sementes iniciais e simulada pelas tabelas de predições de cada um dos genes preditos. Esse processo não é apresentado neste trabalho, mas pode ser implementado e testado, em trabalhos futuros, para uma validação da rede obtida.

\subsection{Materiais e métodos}

Nesta seção, apresentaremos os materiais e métodos empregados pelo processo completo na rede gênica obtida nos resultados experimentais.

\subsubsection{Série-temporal de microarray}

Os dados de entrada de nosso trabalho são baseados nos resultados do experimento em Liu et. al (2004) [26]. O experimento é composto por uma série-temporal de microarray de células T47$D$ tratadas com estrógeno (17 $\beta$-estradiol (E2)) durante 24 horas. O sinal de controle é dado pelo mesmo experimento em células $T-47 D$ não tratadas com estrógeno durante as mesmas 24 horas. O número total de experimentos é de 16 pares (tratados com estrógeno e seu sinal de controle): os primeiros 8 foram medidos a cada hora e os restantes 8 , a cada duas horas. Esse trabalho obteve uma lista de 386 genes responsivos ao estrógeno, e uma lista de 89 genes diretamente regulados por estrógeno. Os dados foram inteiramente armazenados em um banco de dados MySql $^{\mathrm{TM}}$ (<http://www.mysql.com $>$ ). O banco de dados completo pode ser obtido

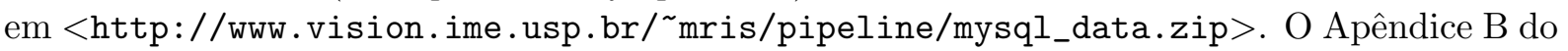
presente trabalho, apresenta uma descrição completa das tabelas do banco de dados.

Os dados foram normalizados e discretizados pelo mesmo método utilizado em [3], com três níveis de discretização $\{-1,0,+1\}$ e com limitantes $l_{i}$ e $u_{i}$ (Equações 4.1 e 4.2 ) para cada gene $i$ do banco de dados.

Cada gene do banco de dados foi pré-processado:

- Localização do gene no banco de dados "Stanford MicroArray" e identificação de seus aliases. Quando um gene não foi encontrado, ele foi marcado, para ser removido do processo completo. 
- Procura de todos os processos biológicos dos quais o gene está envolvido a partir de "Gene Ontology Database" (<http://www.geneontology.org $>$ ) e armazenamento destes em nosso banco de dados $\mathrm{MySql}^{\mathrm{TM}}$.

- Procura de todas as vias às quais o gene está envolvido a partir de "KEGG: Kyoto Encyclopedia of Genes and Genomes" (<http://www.genome.jp/kegg $>$ ) e armazenamento destas mesmas em nosso banco de dados $\mathrm{MySql}^{\mathrm{TM}}$.

- Se o sinal do gene é constante ou indefinido em mais da metade dos experimentos (mais de 8 vezes), o gene foi marcado para ser removido do processo completo.

\subsubsection{Algoritmos}

O pipeline é composto pelos seguintes algoritmos:

- Cada iteração foi processada por um algoritmo desenvolvido em Microsoft Visual Stusio 7.0 ${ }^{\mathrm{TM}}$ que recebeu os genes-sementes como entrada e o banco de dados $\mathrm{MySql}^{\mathrm{TM}}$. Para cada gene $G$ do banco de dados, o algoritmo executa os seguintes processos:

- extração da submatriz contendo a expressão dos genes-sementes no instante $t$ e o gene-alvo $G$ no instante $t+k$;

- execução do algoritmo para encontrar o melhor conjunto preditor;

- armazenamento dos resultados no banco de dados $\mathrm{MySql}^{\mathrm{TM}}$.

- O algoritmo para encontrar o melhor conjunto preditor foi desenvolvido em $C++$. Ele pode executar um dos seguintes métodos: algoritmo U-curve [33] ou busca exaustiva limitada a um determinado tamanho de subconjunto. A saída é composta por uma tabela de predição que contém os melhores subconjuntos de predição utilizando como função custo a entropia condicional média estimada descrita anteriormente.

- Os resultados foram organizados e processados por um algoritmo desenvolvido em Microsoft Visual Studio 7.0 ${ }^{\mathrm{TM}}$ que produzem a entrada para a contrução do grafo que representa a rede.

- O pacote graphviz (<http://www.graphviz.org>) foi utilizado na contrução da imagem do grafo que representa a rede.

- Os redirecionamentos para as tabelas de predições, assim como os gráficos dos sinais de expressão, foram gerados por um algoritmo desenvolvido em Adobe ColdFusion ${ }^{\mathrm{TM}}$ (<http://www. adobe.com/products/coldfusion $>$ ).

Os resultados experimentais foram processados em uma máquina AMD Turion $64^{\mathrm{TM}}$ com 2Gb de memória RAM. O grafo resultante e os genes-sementes para cada iteração podem ser obtidos em <http://www.vision.ime.usp.br/〜mris/pipeline/graph.zip>. 


\section{Capítulo 5}

\section{O Estrógeno e a adesão celular}

Com base em estudos de série-temporal de microarray na presença de estrógeno e iniciandose com uma lista de genes diretamente regulados por estrógeno "genes-sementes", usamos um pipeline de algoritmos para a busca de novos genes preditos pelos "genes-sementes". O resultado de nossa análise nos direcionou a um grupo de genes com um novo processo biológico: adesão celular. Uma lista completa dos genes e suas tabelas de predição relacionando esses genes aos seus preditores foi obtida.

A partir deste estudo, pudemos obter uma evidência do estrógeno regulando genes relacionados à adesão celular. Esse processo biológico ainda não possuia nenhum estudo relacionando esses genes ao estrógeno, e nossos resultados possuem um valor de significância alto para essa relação. Esse resultado nos direciona a uma nova vertente de estudos sobre o estrógeno em tratamentos de câncer, podendo relacionar ele, também, ao estudo de metástase [30].

Em nosso trabalho, procuramos encontrar genes responsivos ao estrógeno de maneira nãodireta, isto é, genes cuja expressão é predita por genes regulados diretamente pelo estrógeno. Os genes regulados diretamente por estrógeno são aqueles que participam de algumas das vias clássicas descritas anteriormente [4].

\subsection{O processo}

A partir de um experimento de série-temporal de microarray obtido do trabalho em [26], no qual foram caracterizados 89 genes regulados diretamente pelo estrógeno e utilizando o modelo para redes genéticas, denominado de redes genéticas probabilísticas (PGNs) [3], obtivemos um conjunto de genes melhores preditos pelo conjunto dos genes diretamente regulados pelo estrógeno. Para isso, um processo baseado no pipeline de algoritmos, visto na Seção 4, e fundamentado no modelo de $P G N s$ foi desenvolvido. Esse processo pode ser resumido pelas seguintes etapas:

- A entrada é a série-temporal de microarray em [26]: um experimento que mede a expressão dos genes (> 19,000 genes) de uma cultura celular T-47D submetidas ao estrógeno durante 16 instantes em 24 horas. Essas expressões foram comparadas a expressão de uma cultura não submetida ao estrógeno (controle) durante as mesmas 24 horas. Uma lista com 89 genes foi obtida no experimento indicando regulação direta do estrógeno sobre eles. 
- Localização do gene no banco de dados "Stanford MicroArray" e identificação de seus aliases. Quando um gene não foi encontrado, ele foi marcado para ser removido do processo completo.

- Identificação das funções biológicas de todos os genes do experimento. Esse processo foi feito pela submissão do identificador dos genes ao banco de dados de ontologia genética (Gene Ontology Database).

- Normalização e discretização dos dados do experimento. Os dados do experimento de entrada podem ser vistos como uma matriz onde cada linha representa o sinal de expressão de um gene do experimento. Esse sinal é um número real: positivo se o gene é superexpresso, próximo a 0 se o gene possui expressão normal, e negativo se o gene é subexpresso. Esses sinais foram normalizados e discretizados em três níveis, $\{-1,0,+1\}$, pelo mesmo método empregado em [3].

- Filtragem dos genes. Os genes com expressão constante, ou os que não foram localizados no banco de dados de microarray ("Stanford MicroArray"), foram descartados do processo. Após essa filtragem, o conjunto de 89 genes, regulados diretamente pelo estrógeno em [26], foi reduzido a um conjunto de 53 genes. Esse subconjunto é denominado de "genessementes".

- Para cada um dos genes (já filtrados) procura-se, entre todos os subconjuntos possíveis $\left(2^{53}\right.$ possibilidades) dos genes-sementes, o "melhor" subconjunto preditor. Esse subconjunto tem a seguinte característica: a distribuição conjunta estimada das expressões dos genes que compõe o subconjunto e o gene analisado possui menor entropia condicional média [3]. Encontrar o melhor conjunto preditor pode ser visto como um problema de seleção de características em Reconhecimentos de Padrão. Várias heurísticas, como: SFFS e SFFS [32], e algoritmos, como: o algoritmo U-curve [33], existem para tratar esse problema. Neste trabalho, usamos a busca exaustiva limitada a um subconjunto de tamanho 3.

- Ordenação dos genes em ordem crescente de custo (ranking). Os genes no topo da lista são os genes melhores preditos pelo conjunto de genes-sementes.

- Seleção dos genes melhores preditos. Para essa seleção são escolhidos os genes onde o melhor subconjunto preditor associado a ele possue menor custo (entropia condicional média - valor $<0,08)$.

- Agrupamento dos genes por suas funções biológicas.

A Figura 5.1 é uma representação esquemática do processso.

\subsubsection{Genes regulados diretamente por estrógeno}

O experimento em [26] obtém 386 genes regulados pelo estrógeno. Para a obtenção dos genes regulados diretamente pelo estrógeno mediu-se os sinais de expressão para duas novas sériestemporais: uma tratada com estrógeno (E2) mais um componente anti-estrógeno (ICI), e outra tratada com etrógeno mais um componente inibidor de síntese de proteína ( $C H X$-cycloheximide). O primeiro experimento filtra os genes que não se expressaram mais na presença do componente 


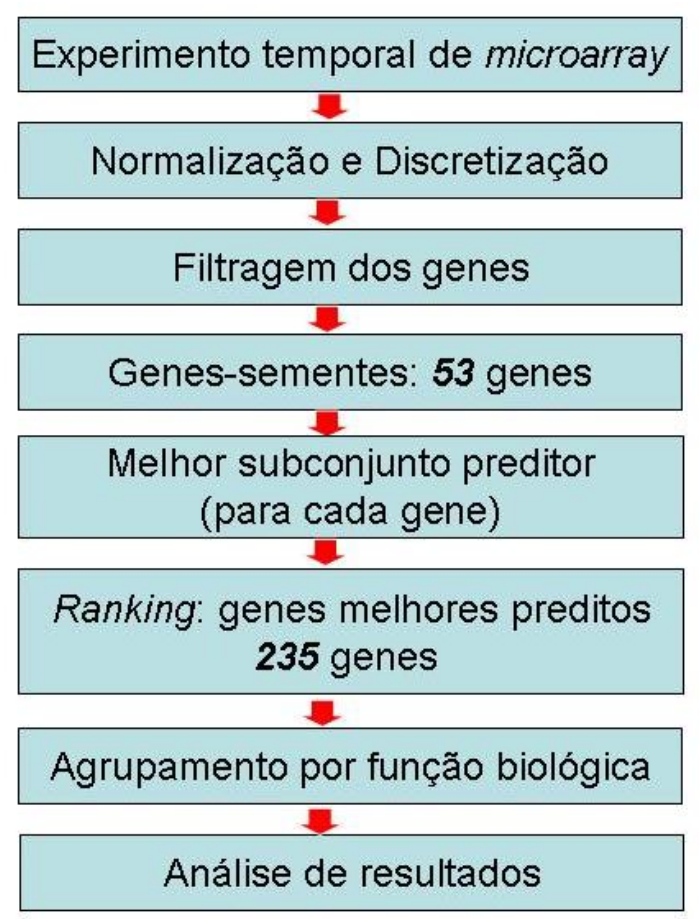

Figura 5.1: Representação esquemática do processo utilizado no experimento

anti-estrógeno (ICI), ou seja, insensíveis ao componente, resultando em 137 genes. O segundo experimento filtra os genes que não se expressaram mais na presença do componente inibidor de proteína $(C H X)$, ou seja, ficando somente os genes expressos sem a presença de nenhum outro fator de transcrição subseqüente, resultando em 89 genes. Desses 89 genes filtramos, para o nosso experimento, os genes que possuem expressão constante (não são informativos para nosso processo) e os genes não encontrados no banco de dados de microarray (Stanford MicroArray), resultando em um conjunto de 53 genes.

A Tabela 5.1 apresenta os 53 genes com suas respectivas entradas $K E G G$ e funções biológicas (ontologias). A Tabela 5.2 e a Figura 5.2 agrupam os genes-sementes entre as funções biológicas mais freqüentes ( $>2$ ocorrências). Podemos verificar que os genes com funções biológicas de transdução de sinal (signal transduction) e regulação da trasncrição (regulation of transcription, $D N A$-dependent) estão entre as funções mais freqüentes. As funções de via de sinalização intracelular (intracellular signaling cascade) e coagulação sangüínea (blood coagulation) merecem destaque nesse conjunto, já que são bem representativas e possuem alto valor de qui-quadrado $\left(\mathcal{X}^{2}\right)$, respectivamente, 28,320 e 64,993 .

\subsubsection{Genes resultantes}

Os genes melhores preditos pelo conjunto de genes-sementes foi obtido pela ordenação (ranking) em ordem crescente de custo (entropia condicional média) relativo ao melhor subconjunto preditor do gene. Foram filtrados os genes cujos custos eram menores que 0, 08, obtendo-se uma lista 


\begin{tabular}{|c|c|c|}
\hline Gene & KEGG & Funções Biológicas (Ontologia) \\
\hline ABCA3 & & $\begin{array}{l}\text { ATP binding ; ATPase activity ; ATPase activity, coupled to transmembrane movement of substances ; integral to } \\
\text { membrane ; membrane fraction ; nucleotide binding ; response to drug ; transport }\end{array}$ \\
\hline ADCY9 & & $\begin{array}{l}\text { adenylate cyclase activity ; cAMP biosynthesis ; integral to plasma membrane ; intracellular signaling cascade ; } \\
\text { isomerase activity ; magnesium ion binding ; peptidyl-prolyl cis-trans isomerase activity ; protein folding }\end{array}$ \\
\hline AFG3L2 & & $\begin{array}{l}\text { ATP binding ; integral to membrane ; membrane ; metalloendopeptidase activity ; mitochondrion ; nucleoside- } \\
\text { triphosphatase activity ; nucleotide binding ; protein catabolism ; proteolysis and peptidolysis ; unfolded protein } \\
\text { binding ; zinc ion binding }\end{array}$ \\
\hline ALOX12B & & $\begin{array}{l}\text { arachidonate 12-lipoxygenase activity ; electron transport ; electron transporter activity ; epidermis development ; } \\
\text { iron ion binding ; leukotriene biosynthesis ; lipid metabolism ; lipoxygenase activity ; oxidoreductase activity }\end{array}$ \\
\hline AMD1 & & $\begin{array}{l}\text { adenosylmethionine decarboxylase activity ; cellular component unknown ; lyase activity ; spermidine biosynthesis } \\
\text {; spermine biosynthesis }\end{array}$ \\
\hline ARPP-21 & & biological process unknown ; cellular component unknown ; nucleic acid binding \\
\hline BMP7 & {$[\mathrm{CYT}][\mathrm{TGF}]$} & cell differentiation ; cytokine activity ; growth ; growth factor activity ; skeletal development \\
\hline \multicolumn{3}{|l|}{ BRI3BP } \\
\hline CAP350 & & cytoskeleton \\
\hline CCNG2 & & cell cycle checkpoint ; cytokinesis ; mitosis ; regulation of cell cycle \\
\hline $\mathrm{CD} 7$ & & $\begin{array}{l}\text { T cell activation ; calcium ion transport ; cellular defense response ; integral to membrane ; membrane fraction ; } \\
\text { plasma membrane ; receptor activity ; transmembrane receptor protein tyrosine kinase signaling pathway }\end{array}$ \\
\hline CENTG1 & & $\begin{array}{l}\text { GTP binding ; GTPase activator activity ; GTPase activity ; kinase activity ; nucleus ; regulation of GTPase } \\
\text { activity ; signal transduction ; small GTPase mediated signal transduction }\end{array}$ \\
\hline $\mathrm{CISH}$ & {$[\mathrm{JAK}]$} & $\begin{array}{l}\text { cellular component unknown ; intracellular signaling cascade ; molecular function unknown ; regulation of cell } \\
\text { growth }\end{array}$ \\
\hline CRABP2 & & $\begin{array}{l}\text { epidermis development ; lipid binding ; regulation of transcription, DNA-dependent ; retinoid binding ; signal } \\
\text { transduction ; transport ; transporter activity }\end{array}$ \\
\hline СтвS & & carbohydrate metabolism ; hydrolase activity, acting on glycosyl bonds ; lysosome ; metabolism \\
\hline CTSD & & $\begin{array}{l}\text { cathepsin D activity ; extracellular region ; lysosome ; pepsin A activity ; peptidase activity ; proteolysis and } \\
\text { peptidolysis }\end{array}$ \\
\hline DGKZ & & $\begin{array}{l}\text { ATP binding ; diacylglycerol binding ; diacylglycerol kinase activity ; diacylglycerol kinase activity ; intracellular } \\
\text { signaling cascade ; kinase activity ; nucleus ; protein kinase C activation ; transferase activity }\end{array}$ \\
\hline ELOVL2 & & endoplasmic reticulum ; fatty acid biosynthesis ; integral to membrane \\
\hline EPHA4 & & $\begin{array}{l}\text { ATP binding; ephrin receptor activity ; integral to plasma membrane ; membrane ; protein amino acid phosphoryla- } \\
\text { tion ; receptor activity ; signal transduction ; transferase activity ; transmembrane receptor protein tyrosine kinase } \\
\text { signaling pathway }\end{array}$ \\
\hline F10 & & $\begin{array}{l}\text { blood coagulation ; calcium ion binding ; chymotrypsin activity ; coagulation factor Xa activity ; extracellular } \\
\text { region ; peptidase activity ; proteolysis and peptidolysis ; trypsin activity }\end{array}$ \\
\hline FLJ13710 & & extracellular matrix ; metalloendopeptidase activity ; peptidase activity \\
\hline \multicolumn{3}{|l|}{ FLJ20986 } \\
\hline FLJ22269 & & integral to membrane \\
\hline GALNT4 & & $\begin{array}{l}\text { Golgi apparatus ; carbohydrate metabolism ; integral to membrane ; manganese ion binding ; polypeptide N- } \\
\text { acetylgalactosaminyltransferase activity ; sugar binding ; transferase activity, transferring glycosyl groups }\end{array}$ \\
\hline GREB1 & & biological process unknown ; cellular component unknown ; molecular function unknown \\
\hline HIG2 & & integral to membrane ; molecular function unknown ; response to stress \\
\hline HSPC111 & & nucleus \\
\hline IGFBP4 & & $\begin{array}{l}\text { DNA metabolism ; cell proliferation ; extracellular region ; insulin-like growth factor binding ; regulation of cell } \\
\text { growth ; signal transduction ; skeletal development }\end{array}$ \\
\hline \multicolumn{3}{|l|}{ IGSF4 } \\
\hline IL6ST & {$[\mathrm{CYT}][\mathrm{JAK}]$} & \\
\hline JAK1 & {$[\mathrm{JAK}]$} & $\begin{array}{l}\text { ATP binding; Janus kinase activity ; cytoskeleton ; intracellular signaling cascade ; protein amino acid phosphory- } \\
\text { lation ; protein-tyrosine kinase activity ; transferase activity }\end{array}$ \\
\hline KCNG1 & & $\begin{array}{l}\text { cation transport ; membrane ; membrane fraction ; potassium ion transport ; protein binding ; voltage-gated } \\
\text { potassium channel activity ; voltage-gated potassium channel complex }\end{array}$ \\
\hline LMCD1 & & biological process unknown ; cellular component unknown ; zinc ion binding \\
\hline LOR & & insoluble fraction ; structural constituent of cytoskeleton \\
\hline
\end{tabular}




\begin{tabular}{|c|c|c|}
\hline Gene & KEGG & Funções Biológicas (Ontologia) \\
\hline MPP3 & & guanylate kinase activity ; integral to plasma membrane ; protein binding ; signal transduction \\
\hline NFIA & & $\begin{array}{l}\text { DNA replication ; electron transport ; heme binding ; nucleus ; nucleus ; regulation of transcription, DNA-dependent } \\
\text {; regulation of transcription, DNA-dependent ; transcription ; transcription factor activity ; transcription factor } \\
\text { activity ; viral genome replication }\end{array}$ \\
\hline \multicolumn{3}{|l|}{ NIF3L1 } \\
\hline NOL5A & & RNA binding ; nucleolus ; rRNA processing \\
\hline NRIP1 & & nucleus ; regulation of transcription, DNA-dependent ; transcription ; transcription coactivator activity \\
\hline OLFM1 & & development ; endoplasmic reticulum ; latrotoxin receptor activity ; membrane ; neurogenesis \\
\hline PAFAH1B1 & & $\begin{array}{l}\text { astral microtubule ; cell cortex ; cell cycle ; cell differentiation ; cell motility ; cytokinesis ; cytoskeleton ; dynein } \\
\text { binding ; establishment of mitotic spindle orientation ; kinetochore ; lipid metabolism ; microtubule associated } \\
\text { complex ; microtubule-based process ; mitosis ; neurogenesis ; nuclear membrane ; signal transduction }\end{array}$ \\
\hline PGR & & $\begin{array}{l}\text { cell-cell signaling; nucleus ; regulation of transcription, DNA-dependent ; signal transduction ; steroid binding ; } \\
\text { steroid hormone receptor activity ; steroid hormone receptor activity ; transcription ; transcription factor activity } \\
\text {; transcription from RNA polymerase II promoter }\end{array}$ \\
\hline PTGES & & $\begin{array}{l}\text { antimicrobial humoral response (sensu Vertebrata) ; integral to membrane ; isomerase activity ; membrane fraction } \\
\text {; prostaglandin metabolism ; prostaglandin-E synthase activity ; signal transduction }\end{array}$ \\
\hline \multicolumn{3}{|l|}{ RBBP8 } \\
\hline RFPL2 & & $\begin{array}{l}\text { protein binding ; protein ubiquitination ; ubiquitin ligase complex ; ubiquitin-protein ligase activity ; zinc ion } \\
\text { binding }\end{array}$ \\
\hline SCN1B & & $\begin{array}{l}\text { integral to membrane ; ion channel activity ; ion transport ; membrane fraction ; sodium ion transport ; synaptic } \\
\text { transmission ; voltage-gated sodium channel activity }\end{array}$ \\
\hline SERPINE1 & & blood coagulation; extracellular region ; plasminogen activator activity ; serine-type endopeptidase inhibitor activity \\
\hline SIAH2 & & $\begin{array}{l}\text { apoptosis ; cell cycle ; cytoplasm ; development ; ligase activity ; nucleus ; protein ubiquitination ; small GTPase } \\
\text { mediated signal transduction ; transcription corepressor activity ; ubiquitin ligase complex ; ubiquitin-dependent } \\
\text { protein catabolism ; ubiquitin-protein ligase activity ; zinc ion binding }\end{array}$ \\
\hline SLC38A1 & & $\begin{array}{l}\text { amino acid transport ; amino acid-polyamine transporter activity ; integral to membrane ; integral to membrane ; } \\
\text { membrane ; neutral amino acid transport ; neutral amino acid transporter activity ; sodium:amino acid symporter } \\
\text { activity ; transport }\end{array}$ \\
\hline $\mathrm{STC} 2$ & & $\begin{array}{l}\text { cell surface receptor linked signal transduction ; cell-cell signaling; extracellular region ; hormone activity ; response } \\
\text { to nutrients }\end{array}$ \\
\hline THBS1 & [TGF][COMM] & $\begin{array}{l}\text { blood coagulation ; calcium ion binding ; cell adhesion ; cell motility ; development ; endopeptidase inhibitor } \\
\text { activity ; extracellular region ; heparin binding ; neurogenesis ; protein binding ; signal transducer activity ; } \\
\text { structural molecule activity }\end{array}$ \\
\hline TPD52L1 & & biological process unknown ; cellular component unknown ; molecular function unknown \\
\hline UGCGL1 & & $\begin{array}{l}\text { UDP-glucose:glycoprotein glucosyltransferase activity ; endoplasmic reticulum ; posttranslational protein folding ; } \\
\text { protein amino acid glycosylation ; protein binding ; transferase activity }\end{array}$ \\
\hline
\end{tabular}

Tabela 5.1: Lista dos 53 genes-sementes 


\begin{tabular}{|c|c|c|c|c|}
\hline Grupo & Freqüência (C) & Total & Valor Esperado (E) & $\mathcal{X}^{2}: \frac{(|C-E|-0.5)^{2}}{E}$ \\
\hline signal transduction & $8[20.51 \%]$ & $862[4.74 \%]$ & 1.850 & 20.443 \\
\hline regulation of transcription, DNA-dependent & $5[12.82 \%]$ & $800[4.40 \%]$ & 1.717 & 6.277 \\
\hline intracellular signaling cascade & $4[10.26 \%]$ & $208[1.14 \%]$ & 0.446 & 28.287 \\
\hline biological process unknown & $4[10.26 \%]$ & $162[0.89 \%]$ & 0.348 & 38.364 \\
\hline neurogenesis & $3[7.69 \%]$ & $185[1.02 \%]$ & 0.397 & 17.063 \\
\hline blood coagulation & $3[7.69 \%]$ & $59[0.32 \%]$ & 0.127 & 64.199 \\
\hline transcription & $3[7.69 \%]$ & $601[3.31 \%]$ & 1.290 & 2.267 \\
\hline transport & $3[7.69 \%]$ & $335[1.84 \%]$ & 0.719 & 7.236 \\
\hline proteolysis and peptidolysis & $3[7.69 \%]$ & $274[1.51 \%]$ & 0.588 & 9.892 \\
\hline development & $3[7.69 \%]$ & $297[1.63 \%]$ & 0.637 & 8.756 \\
\hline
\end{tabular}

Tabela 5.2: Distribuição dos genes-sementes nos vários grupos de funções biológicas

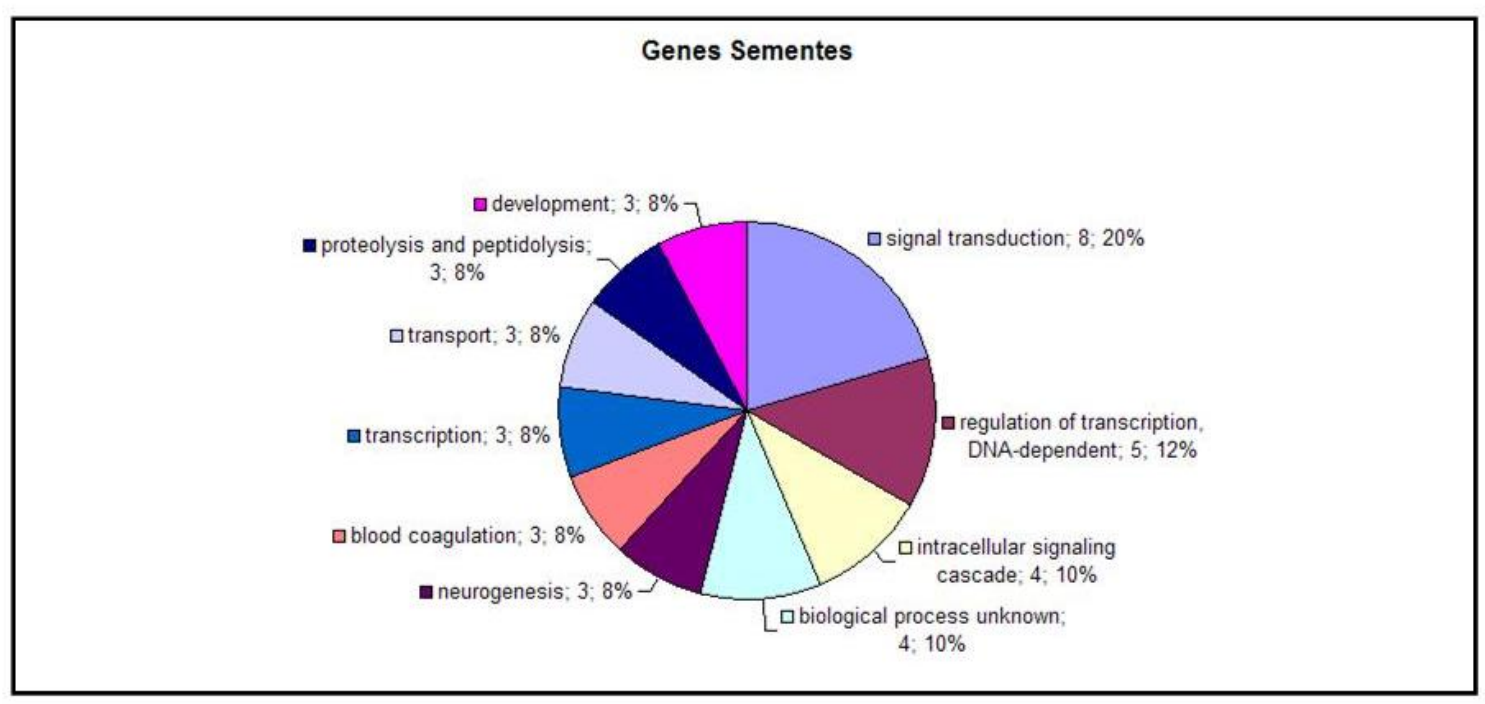

Figura 5.2: Gráfico da distribuição dos 53 genes-sementes por suas funções biológicas

de 235 genes. A Tabela 5.3 apresenta as funções biológicas mais freqüentes (> 2 ocorrências) na lista dos 235 genes filtrados, e a Figura 5.3 dá uma visão gráfica da distribuição.

As funções biológicas relacionadas ao estrógeno, já conhecidas, aparecem em destaque: transdução de sinal (signal transduction), regulação da transcrição (regulation of transcription, DNA-dependent)e fosforilação (phosphorylation) aparecem com freqüência entre os genes preditos. Podemos ressaltar a função de adesão celular (cell adhesion), a qual aparece com destaque no conjunto dos genes preditos: 19 genes $(8 \%)$ com grande significância $\left(\mathcal{X}^{2}=28.906\right)$. Esse resultado nos leva a concluir que o estrógeno pode estar relacionado também com genes de adesão celular. A Tabela 5.4 mostra os 19 genes de adesão celular obtidos. A coluna de preditores indica os melhores cinco conjuntos preditores para cada gene. 


\begin{tabular}{|c|c|c|c|c|}
\hline Grupo & Freqüência (C) & Total & Valor Esperado (E) & $\mathcal{X}^{2}: \frac{(|C-E|-0.5)^{2}}{E}$ \\
\hline signal transduction & $29[7.51 \%]$ & $862[4.74 \%]$ & 18.311 & 5.670 \\
\hline regulation of transcription, DNA-dependent & $25[6.48 \%]$ & $800[4.40 \%]$ & 16.994 & 3.315 \\
\hline transcription & $20[5.18 \%]$ & $601[3.31 \%]$ & 12.767 & 3.551 \\
\hline cell adhesion & $19[3.63 \%]$ & $276[1.52 \%]$ & 5.863 & 28.906 \\
\hline protein amino acid phosphorylation & $19[4.92 \%]$ & $352[1.94 \%]$ & 7.477 & 16.251 \\
\hline transport & $14[3.63 \%]$ & $335[1.84 \%]$ & 7.116 & 5.727 \\
\hline G-protein coupled receptor protein signaling pathway & $11[2.85 \%]$ & $256[1.41 \%]$ & 5.438 & 4.712 \\
\hline cell differentiation & $10[2.59 \%]$ & $154[0.85 \%]$ & 3.271 & 11.862 \\
\hline proteolysis and peptidolysis & $10[2.59 \%]$ & $274[1.51 \%]$ & 5.820 & 2.327 \\
\hline development & $10[2.59 \%]$ & $297[1.63 \%]$ & 6.309 & 1.614 \\
\hline electron transport & $10[2.59 \%]$ & $173[0.95 \%]$ & 3.675 & 9.233 \\
\hline immune response & $10[2.59 \%]$ & $184[1.01 \%]$ & 3.909 & 7.997 \\
\hline cell proliferation & $10[2.59 \%]$ & $199[1.10 \%]$ & 4.227 & 6.578 \\
\hline cell cycle & $9[2.33 \%]$ & $160[0.88 \%]$ & 3.399 & 7.655 \\
\hline neurogenesis & $9[2.33 \%]$ & $185[1.02 \%]$ & 3.930 & 5.314 \\
\hline intracellular signaling cascade & $8[2.07 \%]$ & $208[1.14 \%]$ & 4.418 & 2.150 \\
\hline cell motility & $8[2.07 \%]$ & $89[0.49 \%]$ & 1.891 & 16.637 \\
\hline carbohydrate metabolism & $7[1.81 \%]$ & $148[0.81 \%]$ & 3.144 & 3.582 \\
\hline cell-cell signaling & $7[1.81 \%]$ & $208[1.14 \%]$ & 4.418 & 0.981 \\
\hline lipid metabolism & $7[1.81 \%]$ & $137[0.75 \%]$ & 2.910 & 4.429 \\
\hline ion transport & $7[1.81 \%]$ & $218[1.20 \%]$ & 4.631 & 0.754 \\
\hline sodium ion transport & $6[1.55 \%]$ & $72[0.40 \%]$ & 1.529 & 10.313 \\
\hline protein biosynthesis & $6[1.55 \%]$ & $180[0.99 \%]$ & 3.824 & 0.735 \\
\hline metabolism & $5[1.30 \%]$ & $219[1.21 \%]$ & 4.652 & 0.005 \\
\hline inflammatory response & $5[1.30 \%]$ & $116[0.64 \%]$ & 2.464 & 1.682 \\
\hline protein amino acid glycosylation & $5[1.30 \%]$ & $40[0.22 \%]$ & 0.850 & 15.674 \\
\hline potassium ion transport & $5[1.30 \%]$ & $120[0.66 \%]$ & 2.549 & 1.493 \\
\hline transcription from RNA polymerase II promoter & $5[1.30 \%]$ & $139[0.76 \%]$ & 2.953 & 0.810 \\
\hline spermatogenesis & $5[1.30 \%]$ & $73[0.40 \%]$ & 1.551 & 5.607 \\
\hline apoptosis & $5[1.30 \%]$ & $175[0.96 \%]$ & 3.717 & 0.165 \\
\hline
\end{tabular}




\begin{tabular}{|c|c|c|c|c|}
\hline Grupo & Freqüência (C) & Total & Valor Esperado (E) & $\mathcal{X}^{2}: \frac{(|C-E|-0.5)^{2}}{E}$ \\
\hline sensory perception & $4[1.04 \%]$ & $116[0.64 \%]$ & 2.464 & 0.436 \\
\hline phosphate metabolism & $4[1.04 \%]$ & $18[0.10 \%]$ & 0.382 & 25.450 \\
\hline biological process unknown & $4[1.04 \%]$ & $162[0.89 \%]$ & 3.441 & 0.001 \\
\hline morphogenesis & $4[1.04 \%]$ & $84[0.46 \%]$ & 1.784 & 1.651 \\
\hline protein folding & $4[1.04 \%]$ & $138[0.76 \%]$ & 2.931 & 0.110 \\
\hline phosphate transport & $4[1.04 \%]$ & $45[0.25 \%]$ & 0.956 & 6.770 \\
\hline regulation of cyclin dependent protein kinase activity & $4[1.04 \%]$ & $28[0.15 \%]$ & 0.595 & 14.183 \\
\hline chemotaxis & $3[0.78 \%]$ & $48[0.26 \%]$ & 1.020 & 2.147 \\
\hline regulation of transcription from RNA polymerase II promoter & $3[0.78 \%]$ & $132[0.73 \%]$ & 2.804 & 0.033 \\
\hline phospholipase $\mathrm{C}$ activation & $3[0.78 \%]$ & $13[0.07 \%]$ & 0.276 & 17.921 \\
\hline intracellular protein transport & $3[0.78 \%]$ & $120[0.66 \%]$ & 2.549 & 0.001 \\
\hline epidermal growth factor receptor signaling pathway & $3[0.78 \%]$ & $15[0.08 \%]$ & 0.319 & 14.911 \\
\hline regulation of cell growth & $3[0.78 \%]$ & $46[0.25 \%]$ & 0.977 & 2.374 \\
\hline DNA repair & $3[0.78 \%]$ & $92[0.51 \%]$ & 1.954 & 0.153 \\
\hline cell surface receptor linked signal transduction & $3[0.78 \%]$ & $109[0.60 \%]$ & 2.315 & 0.015 \\
\hline protein amino acid dephosphorylation & $3[0.78 \%]$ & $109[0.60 \%]$ & 2.315 & 0.015 \\
\hline negative regulation of cell cycle & $3[0.78 \%]$ & $60[0.33 \%]$ & 1.275 & 1.177 \\
\hline DNA replication & $3[0.78 \%]$ & $77[0.42 \%]$ & 1.636 & 0.456 \\
\hline glycogen biosynthesis & $3[0.78 \%]$ & $9[0.05 \%]$ & 0.191 & 27.914 \\
\hline regulation of cell cycle & $3[0.78 \%]$ & $162[0.89 \%]$ & 3.441 & 0.001 \\
\hline positive regulation of cytosolic calcium ion concentration & $3[0.78 \%]$ & $34[0.19 \%]$ & 0.722 & 4.379 \\
\hline visual perception & $3[0.78 \%]$ & $121[0.67 \%]$ & 2.570 & 0.002 \\
\hline ubiquitin cycle & $3[0.78 \%]$ & $104[0.57 \%]$ & 2.209 & 0.038 \\
\hline digestion & $3[0.78 \%]$ & $34[0.19 \%]$ & 0.722 & 4.379 \\
\hline
\end{tabular}

Tabela 5.3: Distribuição dos 235 genes preditos por suas funções biológicas 


\begin{tabular}{|c|c|c|}
\hline Gene & Preditores & Entopia \\
\hline CLDN18 & 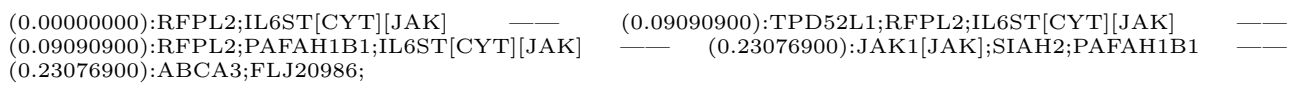 & 0.000 \\
\hline L1CAM & 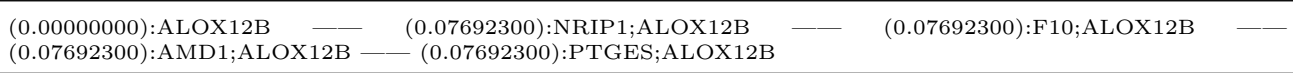 & 0.000 \\
\hline CDH17 & $\begin{array}{l}(0.00000000): \mathrm{CAP} 350 ; \mathrm{BRI3BP}-(0.00000000): \mathrm{BRI3BP}-(0.07692300): \mathrm{F} 10 ; \mathrm{BRI}-\mathrm{BP}-(0.07692300): \mathrm{PT}- \\
\text { GES;BRI3BP }-(0.07692300): \mathrm{AFG}-\mathrm{L} 2 ; \mathrm{PAFAH} 1 \mathrm{~B} 1 ; \mathrm{BRI3BP}\end{array}$ & 0.000 \\
\hline CDH16 & 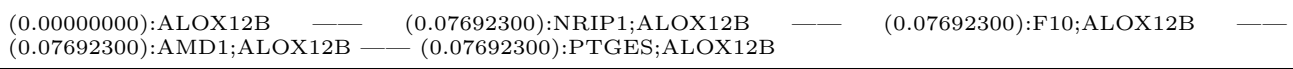 & 0.000 \\
\hline LSAMP & 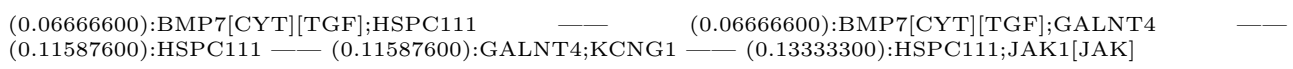 & 0.067 \\
\hline ERBB2IP & $\begin{array}{l}(0.06666600): \text { THBS1[TGF] [COMM];CRABP2 - }(0.14285700): \text { TPD52L1;THBS1[TGF] [COMM];FLJ22269 } \\
(0.15079000): \text { AMD1;CRABP2 - }(0.20316200): \text { CTSD;THBS1[TGF][COMM] — }(0.21745700): \text { F10;CRABP2 }\end{array}$ & 0.067 \\
\hline SPOCK & 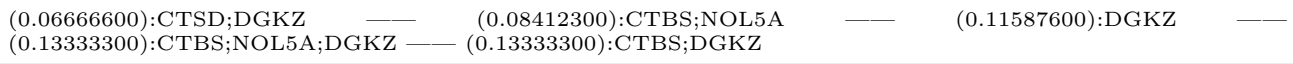 & 0.067 \\
\hline COL4A 6 & $\begin{array}{l}\text { (0.06666600):SIAH2;STC2 }-\begin{array}{c}(0.08333300): T P D 52 L 1 ; R F P L 2 \\
(0.08412300): P T G E S ; S T C 2\end{array}-(0.09013200): \text { CAP350;BRI3BP } \\
\end{array}$ & 0.067 \\
\hline COL17A1 & $\begin{array}{l}(0.06666600): \mathrm{SCN} 1 \mathrm{~B} ; \mathrm{CISH}[\mathrm{JAK}]-(0.15079000): \mathrm{NRIP} 1 ; \mathrm{PTGES} ; \mathrm{STC} 2-(0.18254200): \mathrm{UGCGL} 1 ; \mathrm{PTGES}-\mathrm{C} \\
(0.2000000): \mathrm{NFIA} \text { SCN1B;CISH[JAK] —— }(0.20000000): \mathrm{NRIP} 1 ; \mathrm{PTGES}\end{array}$ & 0.067 \\
\hline PKP4 & 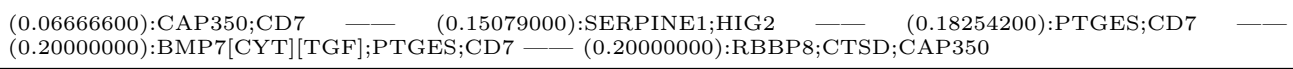 & 0.067 \\
\hline TINAG & $\begin{array}{l}(0.07142800): \text { EPHA 4;IL6ST[CYT][JAK] } \\
(0.14285700): \text { NFIA;EPHA4;IL6ST[CYT][JAK] }\end{array}$ & 0.071 \\
\hline SLIT1 & $\begin{array}{l}(0.07142800): \text { NOL5A;TPD52L1 }-(0.16156100): P T G E S ; T P D 52 L 1-(0.16156100): T P D 52 L 1 ; F L J 13710- \\
(0.16267300): T P D 52 L 1-(0.18848800): T P D 52 L 1 ; R F P L 2\end{array}$ & 0.071 \\
\hline PTPRS & $\begin{array}{l}\text { (0.07142800):AFG3L2;PAFAH1B1;BRI3BP } \\
(0.2000000): A F G 3 L 2 ; \text { LMCD1;PAFAH1B1 - } \\
\text { FAH1B1;BRI3BP;KCNG1 }\end{array}$ & 0.071 \\
\hline F8 & 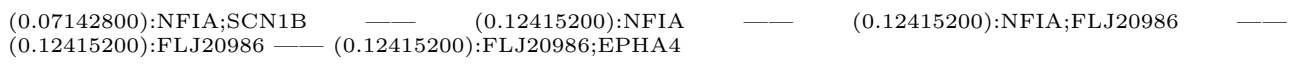 & 0.071 \\
\hline CNTNAP2 & $\begin{array}{l}\text { (0.07692300):FLJ13710;ALOX12B —— }(0.15079000): \text { CRABP2;FLJ13710 —— }(0.15079000): \text { FLJ13710;HIG2 - } \\
(0.17398900): \text { SERPINE1;ALOX12B —— }(0.18254200): G R E B 1 ; C D 7\end{array}$ & 0.077 \\
\hline NEO1 & $\begin{array}{l}(0.07692300): \mathrm{HSPC} 111 ; \mathrm{NRIP} 1-(0.08333300): \mathrm{THBS} 1[\mathrm{TGF}][\mathrm{COMM}] ; \mathrm{BRI} 3 \mathrm{BP}-(0.09706600): \mathrm{NRIP} 1 ; \mathrm{PTGES} \\
\mathbf{-}(0.13370300): \mathrm{HSPC} 111-(0.13370300): \mathrm{HSPC} 111 ; \mathrm{IL} 6 \mathrm{ST}[\mathrm{CYT}][\mathrm{JAK}]\end{array}$ & 0.077 \\
\hline COL8A1 & $\begin{array}{l}(0.07692300): \text { SERPINE1;ALOX12B - }(0.21062600): \text { FLJ13710;ALOX12B }-(0.21428500): A B C A 3 ; F L J 13710 \\
-(0.21745700): \text { STC2;FLJ13710 - }(0.23076900): \text { SERPINE1;FLJ13710;ALOX12B }\end{array}$ & 0.077 \\
\hline $\mathrm{NRP} 2$ & $\begin{array}{l}(0.07692300): \mathrm{AMD} 1 ; \mathrm{ALOX} 12 \mathrm{~B}-(0.14285700): \mathrm{AMD} 1 ; \mathrm{ABCA} 3-(0.15079000): \mathrm{THBS} 1[\mathrm{TGF}][\mathrm{COMM}] ; \mathrm{KCNG} 1 \\
-(0.18254200): \mathrm{JAK} 1[\mathrm{JAK}] ; \mathrm{AMD} 1-(0.18254200): \mathrm{CTSD} ; \mathrm{AMD} 1\end{array}$ & 0.077 \\
\hline KITLG & $\begin{array}{l}(0.07692300): \text { NRIP } 1 ; \mathrm{ALOX} 12 \mathrm{~B} \\
(0.23076900): \mathrm{NRIP} 1 ; \mathrm{LMCD} 1 ; \mathrm{ALOX} 12 \mathrm{~B} \\
(0.23076900): \mathrm{NRIP} 1 ; \mathrm{CCNG} 2 ; \mathrm{ALOX} 12 \mathrm{~B}\end{array}$ & 0.077 \\
\hline
\end{tabular}

Tabela 5.4: Lista dos 19 genes de adesão celular obtidos 


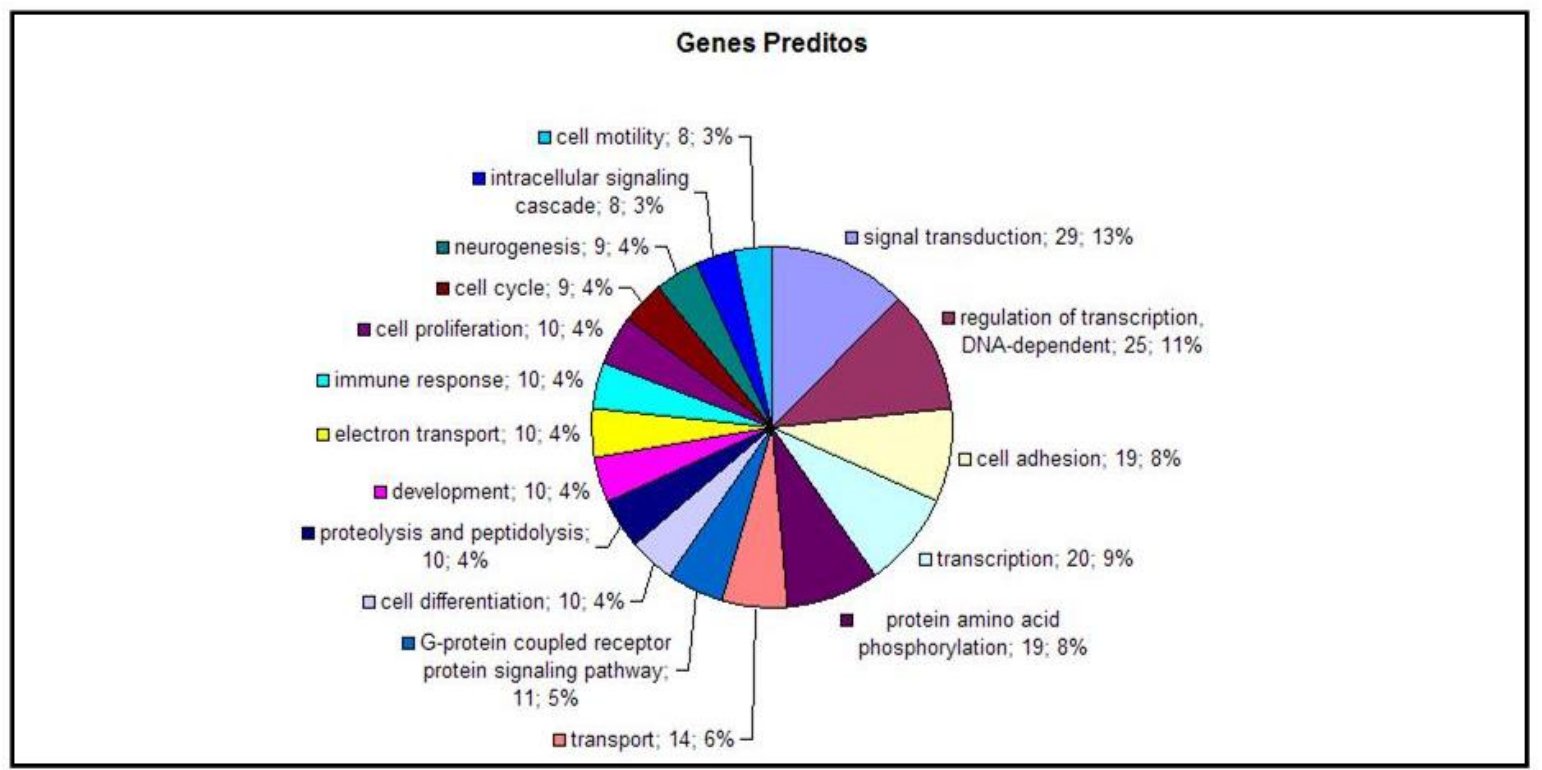

Figura 5.3: Gráfico da distribuição dos 235 genes melhores preditos por suas funções biológicas

No Apêndice C temos: (i) a tabela completa dos 235 genes preditos nessa etapa; (ii) as tabelas de predições para cada um dos 19 genes de adesão celular; e (iii) os gráficos do sinal de expressão destes genes com seus preditores.

\subsection{Discussão}

O processo de metástase consiste em uma complexa seqüência de etapas que envolvem as células tumorais e propriedades do organismo hospedeiro [11]. O descolamento das células tumorais do tumor primário é considerada como a primeira e mais importante etapa no processo metastático. As células tumorais podem mais facilmente ser descoladas de um tecido tumoral compacto do que as células normais nas proximidades de um tecido normal [6]. Esse descolamento das células tumorais é regulada pela propriedade de adesão celular do tumor. A função biológica de adesão celular é empregada aos genes relacionados a moléculas de adesão, as quais atuam como moduladores positivos ou negativos no processo de metástase [18, 30]. Apesar do rápido avanço no entendimento da biologia da adesão celular, os dados disponíveis na literatura tornam difícil a proposição de um modelo simples, no qual pode-se relacionar moléculas de adesão ao crescimento dos tumores e a metástase. Isso pode estar relacionado a um número considerável de fatores. Alguns dos resultados experimentais, aparentemente conflitantes, que demonstram tanto aumento como diminuição da adesão das células tumorais durante a progressão do tumor podem ser atribuídos aos sistemas usados. Aqueles estudos que injetam células tumorais de maneira intravenosa têm, em geral, mostrado que um aumento na função de adesão dessas células possui correlação positiva com a habilidade mestastática. Esses estudos possuem um viés em determinar que a alta função de adesão dessas células faz com que elas tenham facilidade 
em se juntar com células da circulação e serem depositadas em regiões diversas do organismo. Entretanto, estudos que implantam tecidos tumorais em organismos e permitem que cresçam e sofram metástase espontânea têm, geralmente, demonstrado uma relação inversa da função de adesão celular e a habilidade metastática.

A relação do estrógeno como regulador de genes relacionados a adesão celular não é muito destacada na literatura. Neste trabalho, conseguimos obter, a partir de um experimeto de sérietemporal de microarray com células submetidas a estrógeno, uma evidência forte de regulação do estrógeno sobre genes relacionados a essa função. A partir de uma lista inicial de 53 genes regulados diretamente pelo estrógeno [26], uma lista com 20 genes relacionados a adesão celular foi obtida. Para cada um dos genes, uma tabela de predição, relacionando o gene aos genes iniciais diretamente regulados pelo estrógeno, é determinada. Esses resultados, indicam uma forte relação entre o estrógeno e genes de adesão celular e, por conseqüente, a metástase. Os genes obtidos neste trabalho nos dão uma forte evidência da relação entre o estrógeno e a função de adesão celular. Esses dados, porém, precisam ser validados em laboratório. A lista completa dos genes candidatos com suas tabelas de predições são fontes valiosas ao pesquisador para a validação dos resultados. O método empregado em nossos resultados possui forte suporte matemático, ou seja, dado o conjunto de entrada: o experimento e os genes-sementes iniciais - o melhor subconjunto preditor é sempre obtido pela minimização da entropia condicional média (custo) associada à distribuição conjunta do gene e o subconjunto preditor. Sendo assim, à medida que o conjunto de entrada cresce (mais instantes amostrais), o resultado se torna mais confiável. Apesar de, no nosso caso, o experimento de entrada ser pequeno (16 instantes), acreditamos que a evidência do estrógeno influenciando genes de adesão celular é fortemente comprovada pelos resultados.

\subsection{Materiais e métodos}

\subsubsection{Série-temporal de microarray}

Os dados de entrada de nosso trabalho são baseados nos resultados do experimento em Liu et. Al (2004) [26]. O experimento é composto por uma série-temporal de microarray de células T47-D tratadas, durante 24 horas, com: (i) estrógeno (17 $\beta$-estradiol (E2)); (ii) estrógeno (E2) + ICI (componente anti-estrógeno); iii. estrógeno (E2) $+C H X$-Cycloheximide (componente inibidor de síntese de proteína). O sinal de controle é dado pelo mesmo experimento em células T-47D não tratadas com estrógeno durante as mesmas 24 horas. O número total de experimentos é de 16 pares (tratados com estrógeno e seu sinal de controle): os primeiros oito foram medidos a cada hora e, os oito restantes a cada duas horas. O experimento obteve: 385 genes, responsivos ao estrógeno; 139 genes, responsivos ao estrógeno e sensíveis a ICI; 89 genes, responsivos ao estrógeno, sensíveis a ICI e insensíveis a CHX. Esses genes foram denominados como diretamente regulados pelo estrógeno. Os dados foram inteiramente armazenados em um banco de dados $\mathrm{MySql}^{\mathrm{TM}}$ (disponível em <http://www.mysql.com $>$ ). O banco de dados completo pode ser

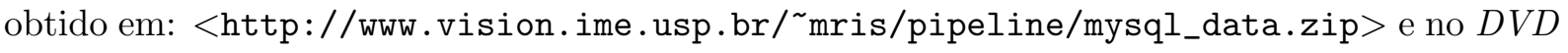
em anexo. Uma descrição completa das tabelas do banco é obtida no Apêndice B.

Os dados foram normalizados e discretizados pelo mesmo método utilizado em [3] com três níveis de discretização $\{-1,0,+1\}$ com limitantes $l_{i}$ e $u_{i}$ (descritos anteriormente) para cada 
gene $i$ do banco de dados.

Cada gene do banco de dados foi pré-processado:

- Localização do gene no banco de dados "Stanford MicroArray" e identificação de seus aliases. Quando um gene não foi encontrado, ele foi marcado para ser removido do processo completo.

- Procura de todos os processos biológicos dos quais o gene está envolvido a partir de "Gene Ontology Database" (<http://www.geneontology.org >) e armazenamento dos mesmos em nosso banco de dados MySql ${ }^{\mathrm{TM}}$.

- Procura de todas as vias as quais o gene está envolvido a partir de "KEGG: Kyoto Encyclopedia of Genes and Genomes" (<http://www.genome.jp/kegg>) e armazenamento das mesmas em nosso banco de dados $\mathrm{MySql}^{\mathrm{TM}}$.

- Se o sinal do gene é constante ou indefinido em mais da metade dos experimentos (mais de oito vezes), o gene foi marcado para ser removido do processo completo.

Os processos foram desenvolvidos a partir de:

- Adobe ColdFusion ${ }^{\mathrm{TM}}$ (<http://www. adobe.com/products/coldfusion>): agrupamento em funções biológicas, tabelas de predições, gráficos de sinais e resultados.

- Microsoft Visual Studio 7.0 ${ }^{\mathrm{TM}}$ : normalização, discretização, processamento e preparação de cada gene para obtenção do melhor subconjunto preditor.

- $C++$ : algoritmo para encontrar o melhor conjunto preditor

Os resultados experimentais foram processados em uma máquina AMD Turion $64^{\mathrm{TM}}$ com 2 Gb de memória $R A M$. 


\section{Capítulo 6}

\section{Conclusão}

Foi apresentado, neste trabalho, resultados em três áreas distintas: Ciência da Computação e Estatística, Bioinformática e Biologia.

Na área da Ciência da Computação e Estatística, desenvolvemos uma solução para o problema de seleção de características em Reconhecimentos de Padrões. Esse problema se caracteriza por buscar, no espaço de subconjuntos das carcaterísticas, o subconjunto com menor função custo associada. No contexto de identificação de redes de expressão gênica, o problema se caracteriza por, dado um conjunto de genes inicial, encontrar o melhor subconjunto preditor para um gene-alvo. Nossa solução, denominada algoritmo U-curve, executa uma busca completa no espaço total de possibilidades sem a necessidade de percorrer o espaço total. Obtivemos resultados consideráveis quando comparamos nosso método com as heurísticas mais usadas para esse problema. Apesar dos resultados obtidos, a presente versão do algoritmo $U$-curve não é uma solução rápida para problemas de dimensões altas, proporcionando algumas novas frentes de pesquisa, tais como: (i) construção de soluções paralelizáveis do algoritmo; (ii) desenvolvimento de novos cortes à formulação branch-and-bound; (iii) desenho e estimação das distribuições das características. Com tudo isso, nossa técnica abre um novo framework de pesquisa para problemas de seleção de características.

$\mathrm{Na}$ área da Bioinformática, descrevemos um método abrangente para modelar redes genéticas utilizando como entrada os dados de um experimento de série-temporal de microarray. Esse método é baseado em um pipeline de algoritmos, no qual cada um deles foi descrito em detalhes e uma solução foi implementada. Obtivemos, como resultado experimental, uma rede de predição representada por um grafo dirigido em que cada nó representa um gene da rede. Esse grafo possui uma apresentação em formato $h t m l$ onde, para cada gene, existem redirecionamentos para: (i) suas tabelas de predições; (ii) gráfico das expressões do gene-alvo e seus preditores; (iii) informações do gene e seus aliases no banco em "Stanford MicroArray" (<http://genome-www5.stanford.edu >); (iv) ontologia; e (v) via $K E G G$ relacionadas. O pipeline, quando empregado a um experimento biológico, é uma ferramenta muito útil ao pequisador, podendo, a partir da rede obtida, desenvolver novas frentes de estudos. Como pesquisas futuras, podemos citar: (i) simulação e validação das redes obtidas; e (ii) construção de um utilitário como ferramenta para a análise de experimentos biológicos.

Para a área da Biologia, evidenciamos que os marcadores dependentes da proliferação ce- 
lular do estrógeno estão basicamente relacionados às seguintes funções biológicas: regulação de transcrição (regulation of transcription - DNA-dependent), ligação com DNA (DNA binding), transdução de sinal (signal transduction) e regulação do ciclo celular (regulation of cell cycle). Isso foi obtido agrupando-se os genes regulados diretamente pelo estrógeno dos resultados em [26] em suas diversas funções biológicas. A partir desses mesmos genes e utilizando o nosso pipeline para uma iteração, obtivemos um conjunto de 235 genes preditos. Este conjunto, quando agrupado segundo suas funções biológicas, apresentou: a adesão celular (cell adhesion) - 19 genes com uma alta significância $\left(\mathcal{X}^{2}=28.906\right)$ - como uma função de relevância entre aquelas obtidas pelos genes preditos. A lista desses genes, com suas tabelas de predições associadas, é uma fonte de dados promissora para estudos que relacionam estrógeno como fator de proliferação celular ao processo de adesão celular e, conseqüentemente, à metástase. 
Apêndice A

Algoritmo U-curve 
Neste Apêndice, apresentaremos o programa desenvolvido em $\mathrm{C}++$, que implementa o algoritmo U-curve. O programa é executado pela linha de comando (por exemplo: uc -iamostras.dat -lamostras.log) e pode receber como entrada os seguintes parâmetros:

- $-i<$ nome $>$ : nome do arquivo texto de entrada - uma matriz $n \times m$ separada por espaços e fim de linha onde cada linha representa uma amostra com $n-1$ colunas representando os valores para cada uma das componentes do conjunto de preditores e a última o valor para a componente predita;

- $-o<$ nome $>$ : nome do arquivo que contém os resultados (padrão = amostras.dat);

- $-l<$ nome $>$ : nome do arquivo de $\log$. Este arquivo contém dados sobre todo o processamento, servindo como análise do processo (padrão = uc_res.txt);

- $-L<n>$ : nível de informações $(n)$ sobre o processamento - 0 (sem informação) a 3 (informação completa) (padrão =1);

- $-t<t>$ : tipo de processamento $(t)$ - 0 (algumas heurísticas); 1 (U-curve sem esgotamento do mínimo); 2 (U-curve com esgotamento do mínimo); 3 (busca exaustiva); 4 (SFFS) (padrão $=1)$;

- $-c<c><t>$ : forma de cálculo da função custo $(c)-0$ (custo sem penalização pela freqüência limitante), 1 (custo de teste com mínimos no meio do reticulado), 2 (custo de teste com dois mínimos no meio do reticulado), 3 (custo de teste com mínimos em lugares aleatórios), 4 (custo com penalização pela freqüência limitante) (padrão $=4$ ); tipo da função custo $(t)$ - 0 (entropia condicional média), 1 (Coeficiente de determinação)i (padrão $=0$ );

- $-r<p>$ : probabilidade $(p)$ de se começar a procura em sentido de Inferior-Superior (0) ou Superior-Inferior (1) (padrão =0,50);

- $-d<f>$ : relachamento da curva em U, para continuar a construção da cadeia para diferenças entre o mínimo encontrado e o último menores que fração (padrão $=0)$;

- $-e<i>$ : valor que indica se o procedimento de esgotamento do mínimo deve ser suspenso se não encontrar um elemento menor que o último encontrado nas próximas $i$ recursões (padrão $=0$, não pára);

- $-s<s>$ : valor que indica se o algoritmo deve ser suspenso se não encontrar um elemento menor que o último encontrado nas próximas $s$ iterações (padrão $=0$, não pára);

- $-S<S>$ : numéro $S$ de iterações até o algoritmo parar (padrão = 0, não pára);

- -\#<m >: valor mínimo para o custo $m$, ao atingir este valor o algoritmo pára (padrão $=0$, vai até o final);

- $-n<f>$ : freqüência limitante $f$ (Seção 4.2.2) para a estimação do custo (padrão =2);

- $-k<s>$ : cadeia de 0s e 1s indicando para retornar apenas o custo associado ao elemento que $s$ representa; 
- $-f<n>$ : $f$ contém um dos seguintes valores: 0 (não roda o SFFS antes), 1 (roda o SFFS antes do U-curve), 2 (roda o SFFS e pára) (padrão $=0$ );

- $-F<d>$ : parâmetro delta para o SFFS (padrão $=3$ );

- $-E<n>$ : executa busca exautiva limitando o nível em $n$, valores negativos começam no sentido Superior-Inferior;

- $-M<m>$ : número máximo $m$ de elementos no resultado final (padrão $=5$ );

- -w: processa uma heurística de pesos para cada componente a ser inserida, ou seja, componentes que melhoram o resultado possuem mais chance de serem selecionadas;

- $-u<n>$ : testa oscilações para $n$ curvas.

O código a seguir apresenta o código fonte para a construção de uma cadeia (FCL_ProcessChain) e para o esgotamento do mínimo (FCL_ExhaustProcess).

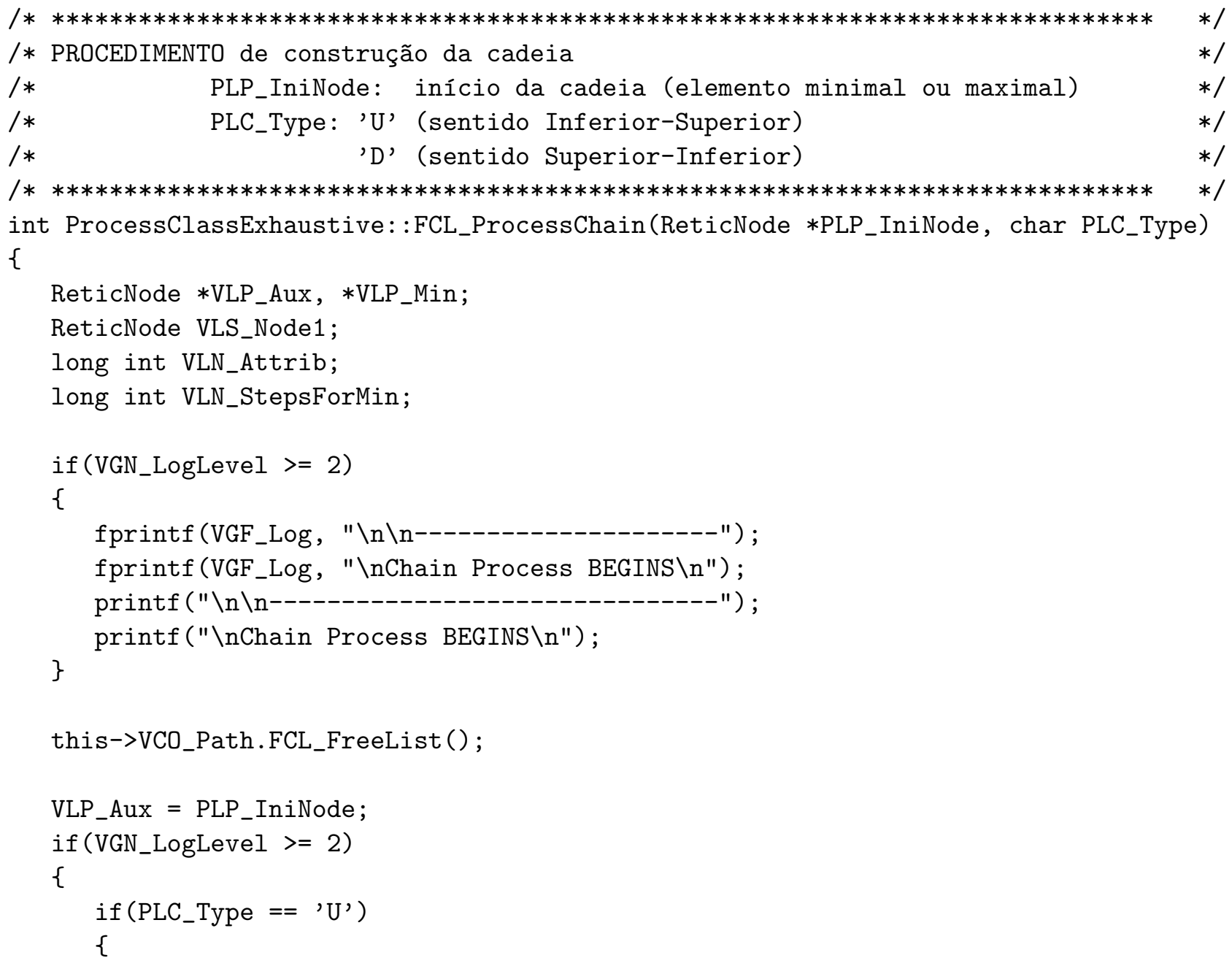




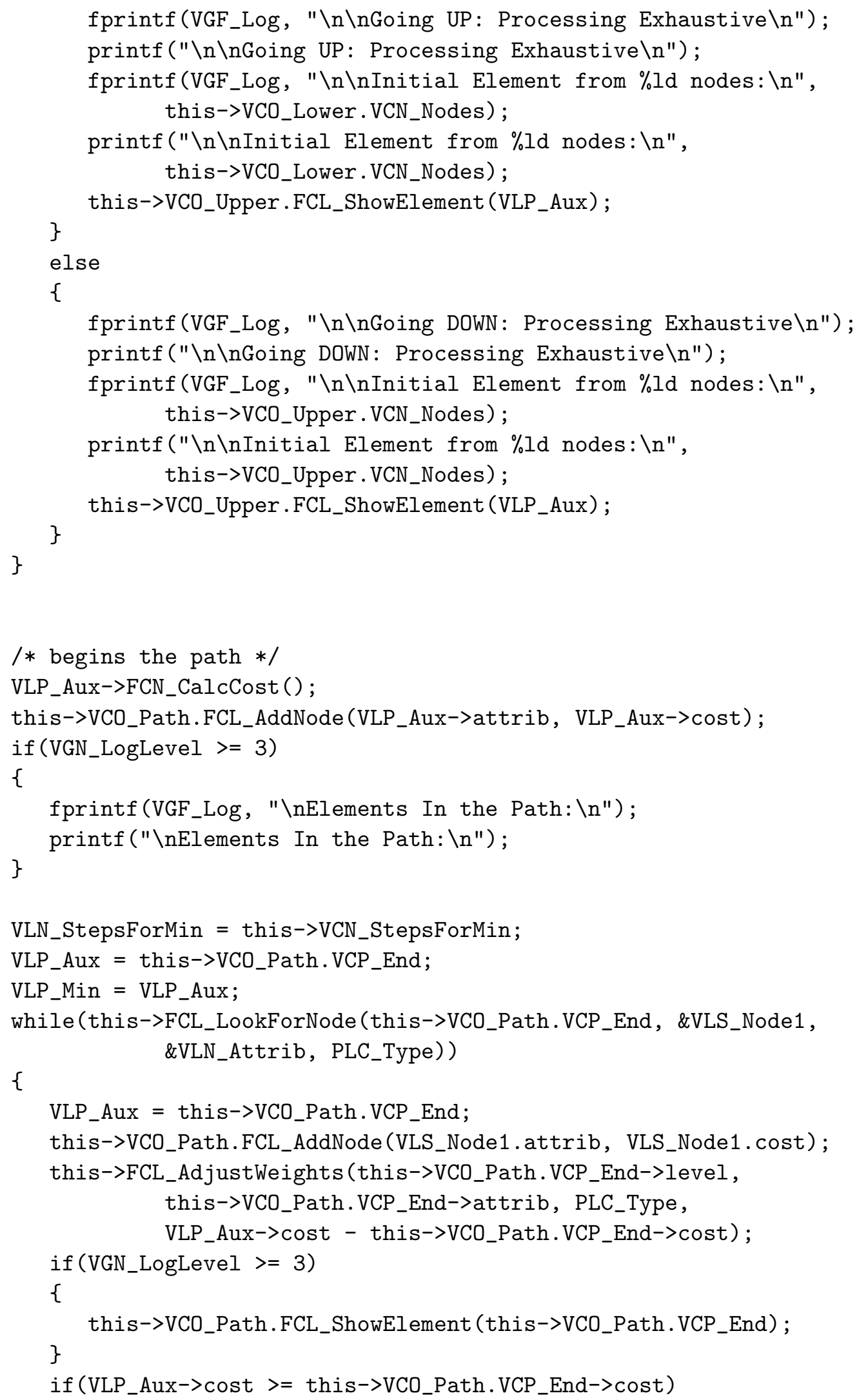




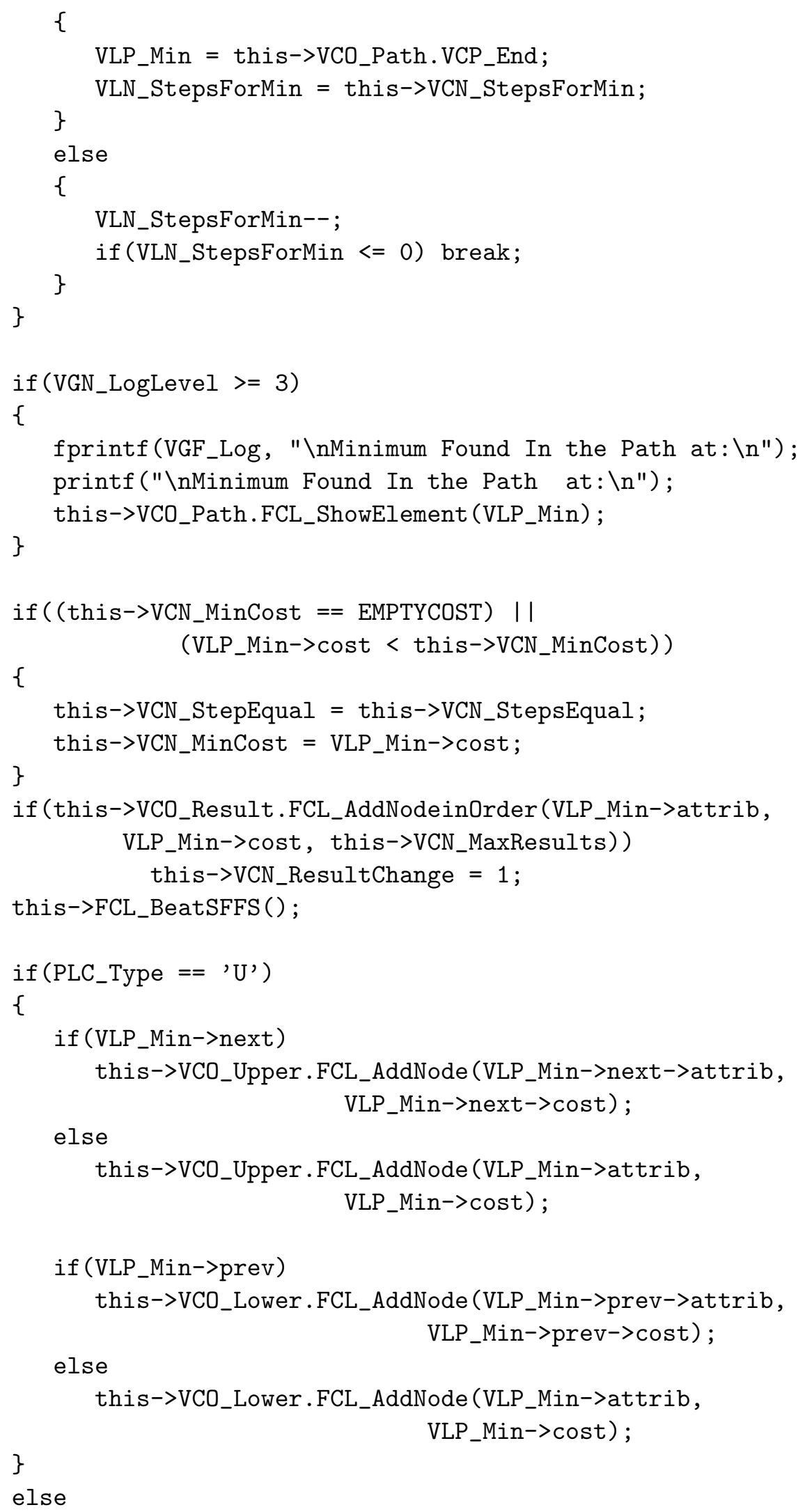


\{

if (VLP_Min->next)

this->VCO_Lower.FCL_AddNode(VLP_Min->next->attrib, VLP_Min->next->cost);

else

this->VCO_Lower.FCL_AddNode(VLP_Min->attrib, VLP_Min->cost);

if (VLP_Min->prev)

this->VCO_Upper.FCL_AddNode (VLP_Min->prev->attrib, VLP_Min->prev->cost);

else this->VCO_Upper.FCL_AddNode(VLP_Min->attrib, VLP_Min->cost);

\}

if (this->VCN_ExecExhaust)

\{ \}

return this->FCL_ExhaustProcess(VLP_Min, PLC_Type);

if (VGN_LogLevel $>=2$ )

\{

fprintf(VGF_Log, "\nChain Process ENDS \n");

fprintf (VGF_Log, "------------------ $\backslash n \backslash n ")$;

printf("\nChain Process ENDS \n");

printf ("------

\}

return 1;

\}

/* ******************************************************************************* $\quad * /$

/* PROCEDIMENTO de esgotamento do mínimo $*$ /

/* PLP_IniNode: elemento inicial */

/* PLC_Type: 'U' (sentido Inferior-Superior) */

I* 'D' (sentido Superior-Inferior) */

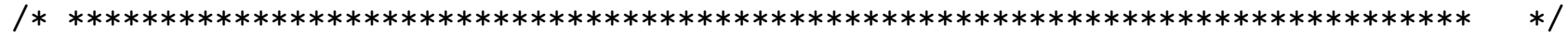

int ProcessClassExhaustive: :FCL_ExhaustProcess(ReticNode *PLP_IniNode, char PLC_Type) \{

ReticNode $*$ VLP_Aux, $*$ VLP_Min, *VLP_AuxBefore;

ReticNode VLS_Node1, VLS_Node2;

ReticNodeList $*$ VLP_List;

long int VLN_Attrib;

int VLL_HasLower; 


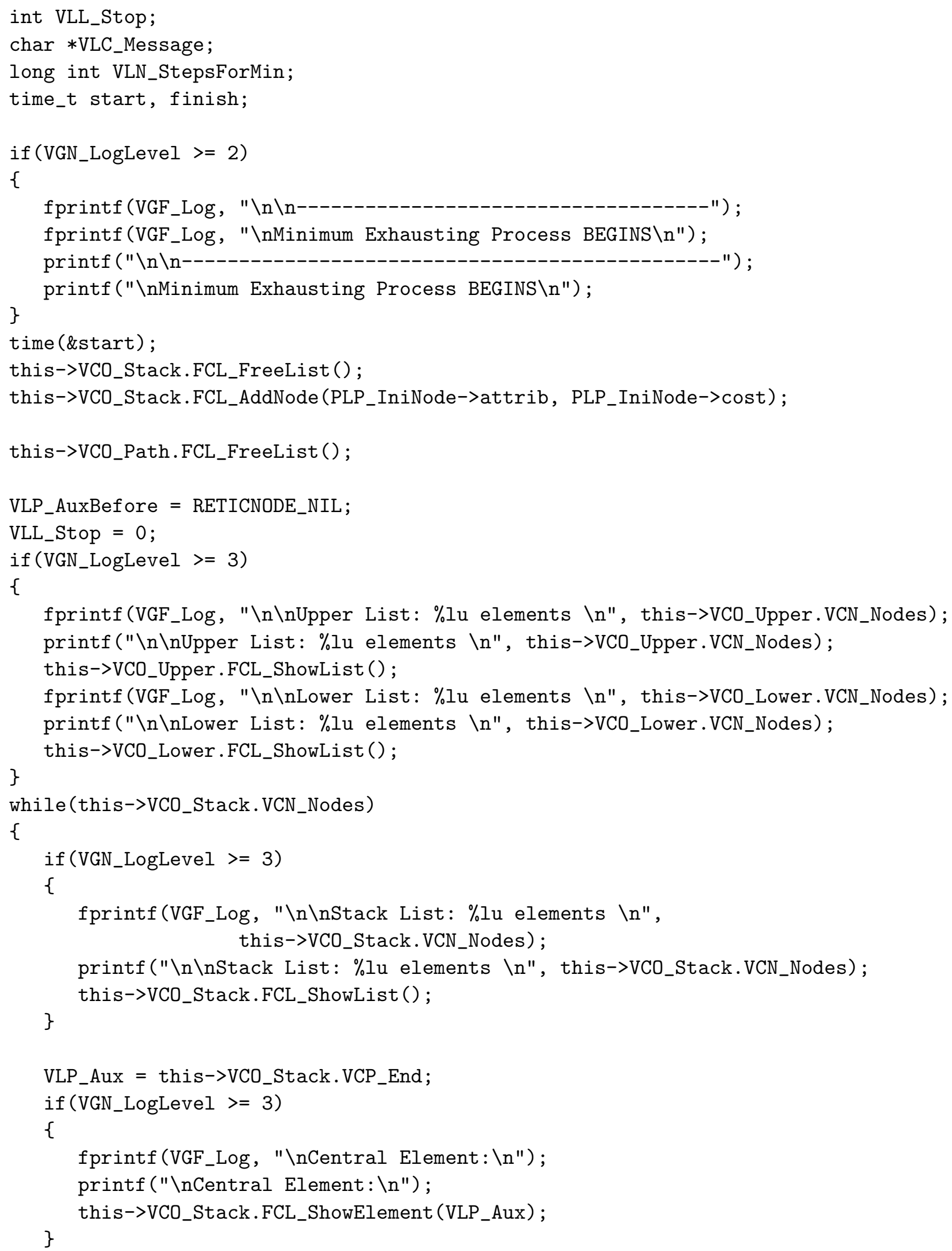




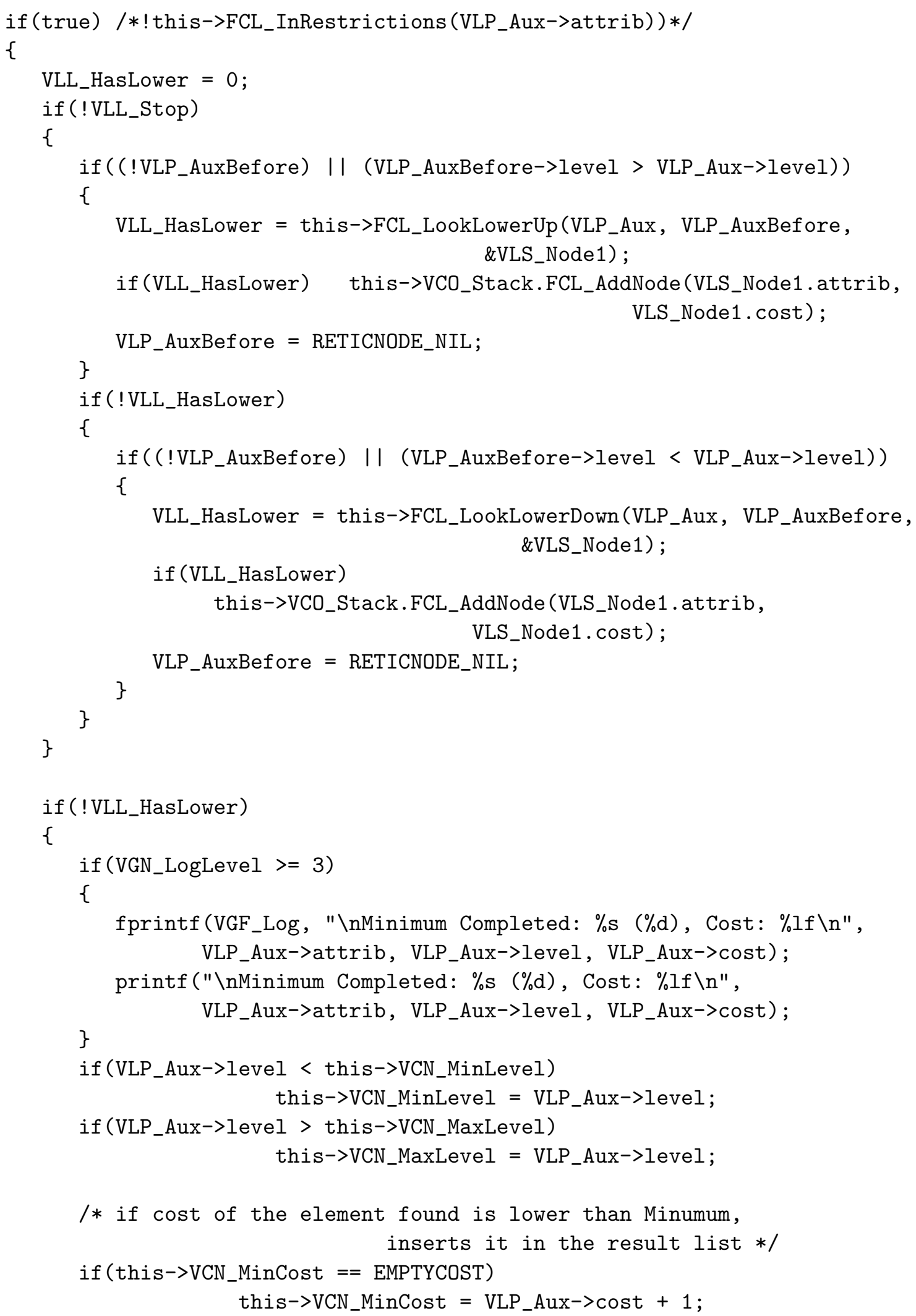




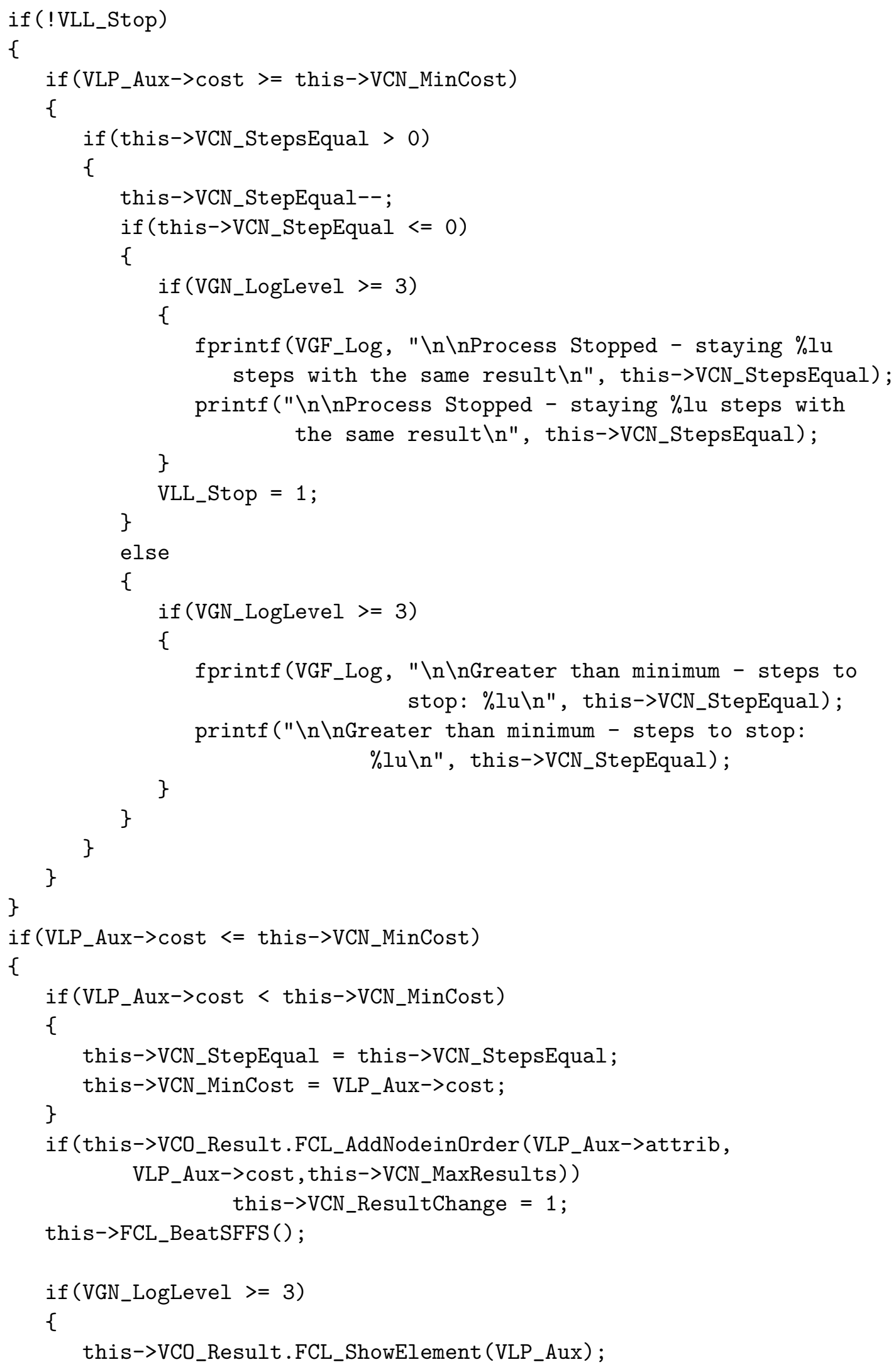




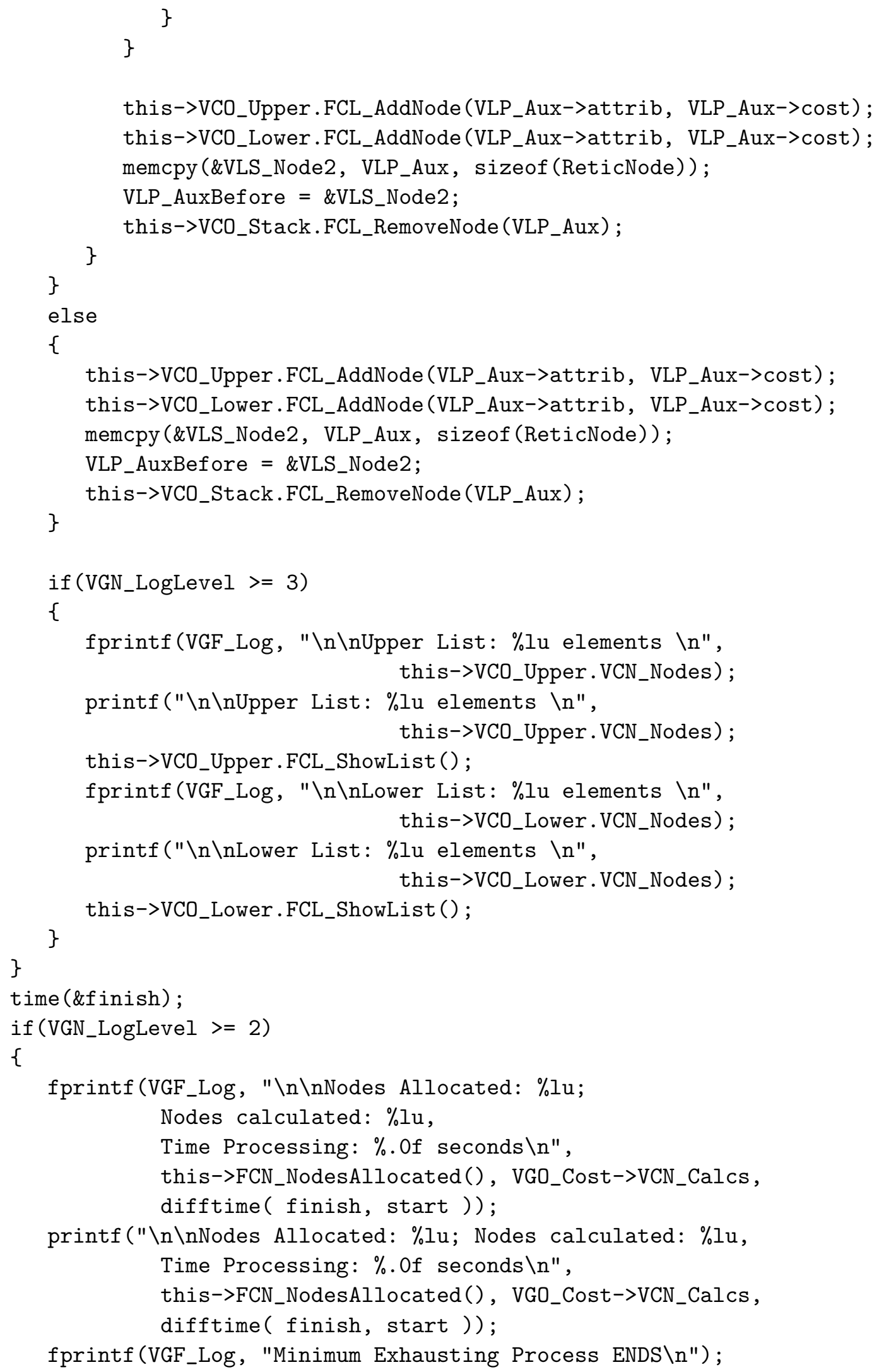


fprintf (VGF_Log, "----------------------------- \n\n"); printf("Minimum Exhausting Process ENDS $\backslash n ")$; printf ("-----\} return 1; \} 
Apêndice B

Pipeline de Algoritmos 
Veremos agora as tabelas componentes do banco de dados MySql ${ }^{\mathrm{TM}}$ usado no pipeline:

- edliugenes - tabela principal do banco de dados, contêm os seguintes campos:

1. genesymbol (varchar(30)) - identificador do gene, nome mais comum pelo qual ele é encontrado na literatura (por exemplo: ADNP para o gene Activity-dependent neuroprotector homeobox);

2. kegg_symb (varchar(50)) - agrupamento dos identificadores das vias do KEGG (por exemplo: $[\mathrm{CC}][\mathrm{AP}])$, onde cada identificador significa:

ACTIN - regulação de actina (regulation of actin cytoskeleton);

AP - apopotose (apoptosis);

CC - ciclo celular (cell cycle);

COMM - comunicação celular (cell communication);

CYT - interação do receptor de citoquina-citoquina (cytokine-cytokine receptor interaction);

JAK - via de sinalização Jak-STAT (Jak-STAT signaling pathway);

KILL - mediador natutal de citotoxidade de morte celular (natural killer cell mediated cytotoxicity);

MAPK - via de sinalização de MAPK (MAPK signaling pathway);

TCELL - via de sinalização de receptor de célula $\mathrm{T}$ ( $T$ cell receptor signaling pathway);

TGF - via de sinalização de TGF-beta ( TGF-beta signaling pathway);

TOLL - via de sinalização de receptor tipo TOLL (Toll-like receptor signaling pathway);

WNT - via de sinalização de Wnt ( Wnt signaling pathway);

3. kegg_descr (varchar(200)) - agrupamento das descrições dos identificadores das vias do KEGG (por exemplo: Cell Communication,TGF-beta signaling pathway);

4. marker (varchar(50)) - marcações para identificar os em que grupo os genes estão (por exemplo: [386][139]):

386 - pertence a lista de 386 genes responsivos ao estrógeno obtidos em [26];

139 - pertence a lista de 139 genes regulados pelo estrógeno obtidos em [26];

89 - pertence a lista de 89 genes diretamente regulados por estrógeno obtidos em $[26]$

- edliuexpr - tabela que armazena os sinais de expressão dos genes, contêm os seguintes campos:

1. genesymbol (varchar(30)) - identificador do gene;

2. expression (text) - contém a o sinal de expressão do gene obtido diretamente do experimento (por exemplo: -0.19084621,0.18350670,0.08434014);

3. expression_n (text) - contém a o sinal de expressão normalizado do gene (por exemplo: $-0.80893650,1.13035355,0.61663314)$;

4. expression_nq (text) - contém a o sinal de expressão normalizado e discretizado do gene (por exemplo: 0,1,0); 
- edliugengo - tabela que relaciona um gene com suas funções biológicas (ontologia), contêm os seguintes campos:

1. genesymbol (varchar(30)) - identificador do gene;

2. genegroup (varchar(100)) - função biológica do gene (por exemplo: cell cycle);

3. genetype (varchar(200)) - tipo de função biológica (biological process, molecular function, cellular component);

4. gonumber (varchar(10)) - número identificador da ontologia em "Gene Ontology Database" (<http://www.geneontology.org >);

5. evidence (varchar $(20))$ - código de evidência da ontologia (por exemplo: $I C, N D$, NAS) em "Gene Ontology Database" (<http://www.geneontology.org >);

- edliutest - armazena os testes (iterações) do pipeline, contêm os seguintes campos::

1. testid (varchar(30)) - identificador do teste (por exemplo: TESTE1_STEP1);

2. testdescr (varchar(200)) - descrição do teste (por exempo: Test 1 (386+kegg+go), Step 1, Skip 1);

3. predictors (text) - texto contendo o símbolos do conjunto de genes-sementes (por exemplo: ADNP;AREG;CCNG2;CD164;CRABP2;DKC1);

4. sementeselect (text) - texto como comaando $S Q L$ para selecionar o conjunto de genessementes;

- edliutest_res - armazena os resultados dos testes para cada gene, contêm os seguintes campos:

1. genesymbol (varchar(30)) - identificador do gene;

2. testid (varchar(30)) - identificador do teste;

3. entropy (double) - valor para o custo (entropia condicional média) relativo ao melhor subconjunto preditor;

4. predictors ( $\operatorname{varchar}(200))$ - armazena os subconjuntos preditores com suas entropias relativas (por exemplo: (0.00000000):SCN1B;GREB1, (0.06666600):NIF3L1;GREB1, indica o subconjunto preditor (SCN1B,GREB1), com entropia 0; e o subconjunto (NIF3L1,GREB1), com entropia 0,06666600);

5. reshtml (text) - código html para a página com as taabelas de predição.

A Figura B.1 é uma representação esquemática do banco de dados com suas tabelas e relacionamentos.

A Tabela B.1 contêm os 33 genes-sementes do resultado do pipeline (Seção 4.2.5). A Tabela B.2 contêm os 38 genes melhores preditos com seus conjuntos de preditores no primeiro passo, a Tabela B.3 contêm os 37 do segundo passo, e a Tabela B.4 contêm os 38 do terceiro passo. 


\begin{tabular}{|c|c|c|}
\hline ADNP & & regulation of transcription, DNA-dependent \\
\hline CCNG2 & & cell cycle checkpoint \\
\hline CD164 & & negative regulation of cell proliferation \\
\hline CRABP2 & & regulation of transcription, DNA-dependent \\
\hline $\mathrm{DKC} 1$ & & cell proliferation \\
\hline DNMT3L & & DNA methylation \\
\hline DSIPI & & regulation of transcription, DNA-dependent \\
\hline EPAS1 & & regulation of transcription, DNA-dependent \\
\hline ERBB4 & & cell proliferation \\
\hline ESPL1 & {$[\mathrm{CC}]$} & regulation of cell cycle \\
\hline FRAT2 & {$[\mathrm{WNT}]$} & cell proliferation \\
\hline $\mathrm{HOXC} 13$ & & regulation of transcription, DNA-dependent \\
\hline IGFBP4 & & DNA metabolism \\
\hline IRF1 & & cell cycle \\
\hline KLF3 & & regulation of transcription, DNA-dependent \\
\hline LASS2 & & regulation of transcription, DNA-dependent \\
\hline MPHOSPH1 & & cell cycle arrest \\
\hline MPHOSPH6 & & M phase of mitotic cell cycle \\
\hline MYBL1 & & regulation of transcription, DNA-dependent \\
\hline NBL1 & & cell cycle \\
\hline NFIA & & DNA replication \\
\hline NRIP1 & & regulation of transcription, DNA-dependent \\
\hline ORC1L & {$[\mathrm{CC}]$} & DNA replication \\
\hline PAFAH1B1 & & cell cycle \\
\hline PGR & & regulation of transcription, DNA-dependent \\
\hline POU1F1 & & negative regulation of cell proliferation \\
\hline PRDM14 & & regulation of transcription, DNA-dependent \\
\hline REL & & regulation of transcription, DNA-dependent \\
\hline SIAH2 & & cell cycle \\
\hline TACSTD2 & & cell proliferation \\
\hline TBX21 & & regulation of transcription, DNA-dependent \\
\hline TBX6 & & regulation of transcription, DNA-dependent \\
\hline ТОВ1 & & negative regulation of cell proliferation \\
\hline
\end{tabular}

Tabela B.1: Tabela com os 33 genes-sementes iniciais do resultado do pipeline 


\begin{tabular}{|c|c|c|c|c|}
\hline Gene & Preditores & Entropia & KEGG & Função Biológica \\
\hline FOXC1 & $\begin{array}{l}(0.00000000): \text { POU1F1;CD164 } \\
(0.07142800): \text { REL;POU1F1;CD164 } \\
\quad(0.07142800): \text { NRIP } 1 ; \text { CD164 } \\
\text { (0.07142800):POU1F1;LASS2;CD164 } \\
(0.07142800): \text { LASS2;CD164 }\end{array}$ & 0.000 & & regulation of transcription, DNA-dependent \\
\hline BHLHB2 & $\begin{array}{l}(0.06666600): \text { PAFAH1B1;MPHOSPH6 } \\
(0.13333300): \text { DKC } 1 ; \text { ADNP },(0.13333300): \text { DKC } 1 ; \text { MPHOSPH6 } \\
\quad(0.2000000): \text { PRDM14;ADNP } \\
(0.20000000): \text { MYBL } 1 ; \text { MPHOSPH6 }\end{array}$ & 0.067 & & regulation of transcription, DNA-dependent \\
\hline $\mathrm{CCNC}$ & $\begin{array}{l}(0.06666600): \text { PRDM14;CD164 } \\
(0.26666600): \text { PRDM14;TOB1;CD164 } \\
\quad(0.28412300): \text { ERBB4;PGR;CD164 } \\
(0.31483800): \text { TOB1;AREG },(0.33333300): \text { NFIA;TOB1;AREG }\end{array}$ & 0.067 & & regulation of cell cycle \\
\hline CDKN1B & $\begin{array}{l}(0.06666600): \mathrm{PRDM} 14 ; \mathrm{TBX} 6 \quad, \quad(0.06666600): \mathrm{REL} ; \mathrm{TBX} 6 \\
, \quad(0.13333300): \mathrm{TBX} 6 ; \mathrm{TBX} 21 ; \mathrm{FRAT} 2[\mathrm{WNT}] \\
, \quad(0.13333300): \mathrm{TBX} 6 ; \mathrm{FRAT} 2[\mathrm{WNT}] \\
(0.13333300): \mathrm{TBX} 6 ; \mathrm{IGFBP} 4\end{array}$ & 0.067 & {$[\mathrm{CC}]$} & cell cycle arrest \\
\hline ELF5 & $\begin{array}{l}(0.06666600): \text { PRDM } 14 ; \mathrm{HOXC} 13 \\
(0.15079000): \text { PRDM } 14 ; \mathrm{CD} 164 \\
(0.21745700): \text { TACSTD } 2 ; \mathrm{DKC} 1 \\
(0.26666600): \text { DNMT3L;PRDM } 14 \\
(0.26666600): \text { DNMT3L;PRDM } 14 ; \mathrm{NBL} 1\end{array}$ & 0.067 & & DNA binding \\
\hline $\mathrm{F} 2$ & $\begin{array}{l}(0.06666600): \text { SIAH2;DKC1 } \quad, \quad(0.06666600): S I A H 2 ; A R E G \\
(0.13333300): \text { SIAH2;NBL1 },(0.13333300): \text { SIAH2;NBL1;DKC1 } \\
,(0.15079000): D N M T 3 L ; R E L ; N B L 1\end{array}$ & 0.067 & {$[\mathrm{ACTIN}]$} & regulation of cell cycle \\
\hline FEN1 & $\begin{array}{l}(0.06666600): \text { DNMT3L;PRDM14 } \\
(0.06666600): \text { DNMT3L;PRDM14;NBL1 } \\
(0.20000000): \text { DNMT3L;PRDM14;DKC1 } \\
\text { (0.23175200):DNMT3L;NBL1;DKC1 } \\
(0.23175200): \text { DNMT3L;DKC1 }\end{array}$ & 0.067 & & DNA replication \\
\hline FLJ13265 & $\begin{array}{l}(0.06666600): \text { PAFAH1B1;AREG } \\
\begin{array}{l}(0.13333300): \text { DSIPI;PAFAH1B1;AREG } \quad(0.13333300): \text { PA- } \\
\text { FAH1B1;CRABP2 } \quad(0.18254200): D S I P I ; P A F A H 1 B 1\end{array} \\
(0.20000000): \text { NFIA;PAFAH1B1;AREG }\end{array}$ & 0.067 & & regulation of cell cycle \\
\hline MAPK13 & $\begin{array}{l}(0.06666600): \text { TBX6;KLF3 } \quad, \quad(0.13333300): \text { DNMT3L;TBX6 } \\
\begin{array}{c}(0.16824700): T B X 6 \\
(0.19558100): \text { ESPL1[CC];AREG }\end{array}, \quad(0.18254200): \text { TBX6;AREG }\end{array}$ & 0.067 & {$[\mathrm{MAPK}][\mathrm{T}$} & Ore屯l] cycle \\
\hline NEUROD1 & $\begin{array}{l}(0.06666600): P R D M 14 ; C C N G 2 \quad(0.11587600): P R D M 14 ; \mathrm{AREG} \\
\begin{array}{l}(0.13333300): \mathrm{PRDM} 14 ; \mathrm{TACSTD} 2 \\
(0.13333300): \mathrm{PRDM} 14 ; \mathrm{DSIPI}\end{array}\end{array}$ & 0.067 & & DNA binding \\
\hline PER2 & $\begin{array}{c}\left.\begin{array}{c}(0.06666600): \text { NFIA;POU1F1 } \\
(0.06666600): \text { NFIA;EPAS1 }\end{array}, \quad, \quad \begin{array}{c}(0.06666600): \text { NFIA;TOB1 } \\
(0.11587600): \text { NFIA;AREG }\end{array}, \quad, 11587600\right): \text { NFIA }\end{array}$ & 0.067 & & regulation of transcription, DNA-dependent \\
\hline PFDN1 & $\begin{array}{l}(0.06666600): \text { DNMT3L;CD164 }, \quad(0.16824700): \text { KLF3;CRABP2 } \\
, \quad(0.20000000): \text { DNMT3L;REL;CRABP2 } \\
, \quad(0.20000000): \text { DNMT3L;REL;CD164 } \\
(0.20000000): \text { DNMT3L;KLF3;CRABP2 }\end{array}$ & 0.067 & & cell cycle \\
\hline
\end{tabular}




\begin{tabular}{|c|c|c|c|c|}
\hline Gene & Preditores & Entropia & KEGG & Função Biológica \\
\hline PTEN & $\begin{array}{l}(0.06666600): \text { PAFAH1B1;MPHOSPH6 } \\
(0.21745700): \text { DSIPI;CD164 } \quad(0.21745700): \text { PA- } \\
\text { FAH1B1;PGR } \quad(0.26666600): \text { ERBB4;PAFAH1B1;PGR } \\
(0.29841800): \text { ERBB } 4 ; \text { PGR }\end{array}$ & 0.067 & & cell cycle \\
\hline RFX2 & $\begin{array}{l}(0.06666600): \text { SIAH } 2 ; H O X C 13, \quad(0.18254200): R E L ; H O X C 13 \\
\quad(0.2000000): R E L ; S I A H 2 ; H O X C 13 \\
(0.20000000): \text { SIAH } 2 ; \text { PAFAH1B1;HOXC13 } \\
(0.23491400): \text { PRDM } 14 ; \text { CD } 164\end{array}$ & 0.067 & & DNA binding \\
\hline SALL2 & $\begin{array}{l}(0.06666600): \mathrm{DKC} 1 ; \mathrm{CRABP} 2,(0.13333300): \mathrm{DKC} 1 ; \mathrm{CCNG} 2 \\
(0.13333300): \mathrm{DKC} 1 ; \mathrm{ADNP},(0.13333300): \mathrm{DKC} 1 ; \mathrm{MPHOSPH} 6 \\
(0.13333300): \mathrm{CCNG} 2 ; \mathrm{AREG}\end{array}$ & 0.067 & & regulation of transcription, DNA-dependent \\
\hline SMARCA5 & $\begin{array}{l}(0.06666600): \text { SIAH2;TOB } 1 \\
(0.13333300): \text { SIAH2;TOB } 1 ; \text { IGFBP } 4 \\
(0.20000000): \text { REL; SIAH2;TOB } 1,(0.21745700): \text { SIAH2;ADNP } \\
,(0.23298900): \text { SIAH } 2 ; \text { ESPL } 1[C C]\end{array}$ & 0.067 & & DNA binding \\
\hline TGFB3 & $\begin{array}{l}(0.06666600): \text { TBX } 21 ; \mathrm{FRAT} 2[\mathrm{WNT}] \\
(0.13333300): \mathrm{TBX} 6 ; \mathrm{TBX} 21 ; \mathrm{FRAT} 2[\mathrm{WNT}],(0.13333300): \mathrm{PA}- \\
\text { FAH1B1;PGR },(0.20000000): \mathrm{TBX} 21 ; \mathrm{FRAT} 2[\mathrm{WNT}] ; \mathrm{CCNG} 2 \\
(0.21745700): \mathrm{PAFAH} 1 \mathrm{~B} 1 ; \mathrm{CRABP} 2\end{array}$ & 0.067 & {$[\mathrm{MAPK}][\mathrm{C}$} & 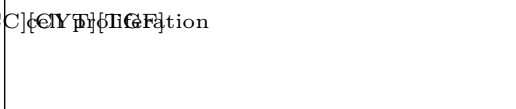 \\
\hline YAF2 & $\begin{array}{l}(0.06666600): \text { DNMT3L;CD164 } \\
(0.20000000): \text { DNMT3L;REL;CRABP2 } \\
, \quad(0.20000000): \text { DNMT3L;REL;CD164 } \\
, \quad(0.23491400): \text { DNMT3L;REL } \\
(0.23491400): \text { DNMT3L;REL;NBL1 }\end{array}$ & 0.067 & & regulation of transcription, DNA-dependent \\
\hline ZFP95 & $\begin{array}{l}(0.06666600): \text { MYBL } 1 ; \mathrm{ERBB} 4,(0.13333300): \text { TACSTD2;DSIPI } \\
\quad(0.18254200): \text { TBX21;DSIPI } \\
(0.20000000): \text { PRDM } 14 ; \text { TACSTD2;AREG } \\
(0.20000000): \text { TBX21;TACSTD2;DSIPI }\end{array}$ & 0.067 & & regulation of transcription, DNA-dependent \\
\hline RARRES1 & $\begin{array}{l}(0.07142800): \text { ESPL } 1[\mathrm{CC}] ; \text { MPHOSPH6 } \\
\quad(0.20316200): \text { NFIA;TOB } 1 \\
(0.21428500): \text { NFIA;ESPL1[CC];MPHOSPH6 } \\
(0.21428500): \text { MPHOSPH } 1 ; \text { ESPL1[CC];MPHOSPH6 } \\
(0.21745700): \text { NFIA;TOB } 1 ; \text { AREG }\end{array}$ & 0.071 & & negative regulation of cell proliferation \\
\hline TCF 19 & $\begin{array}{l}(0.07142800): \text { ERBB } 4 \text {;PAFAH1B1 }, \quad(0.12415200): \text { ERBB4 } \\
(0.14285700): \text { MYBL } 1 ; \text { ERBB4 }, \quad, \quad(0.16156100): \text { KLF3;ERBB } 4 \\
(0.16156100): \text { ERBB } ; \text {;CD164 }\end{array}$ & 0.071 & & cell proliferation \\
\hline TCF8 & 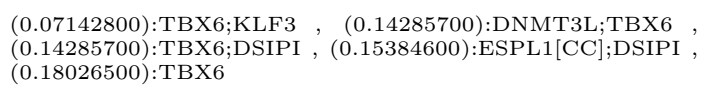 & 0.071 & & cell proliferation \\
\hline $\mathrm{XPC}$ & 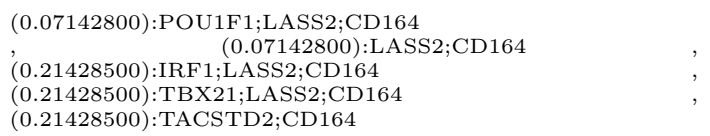 & 0.071 & & damaged DNA binding \\
\hline ZNF20 & $\begin{array}{l}(0.08333300): \text { KLF3;ERBB4 } \quad, \quad(0.14484500): \text { ERBB4 } \\
(0.16666600): \text { NFIA;KLF3 }, \quad(0.16666600): \text { NFIA;KLF3;ERBB4 } \\
,(0.16666600): \text { NFIA;ERBB4 }\end{array}$ & 0.083 & & DNA binding \\
\hline FOXD2 & $\begin{array}{l}(0.09013200): \text { NFIA;ERBB } 4, \quad(0.09013200): \text { KLF } 3 ; \text { ERBB } 4 \\
(0.09013200): \text { ERBB } \quad, \quad(0.14285700): \text { NFIA;IRF } 1 \text { ERBB } 4 \\
(0.14285700): \text { NFIA;ERBB } 4 ; \text { TOB } 1\end{array}$ & 0.090 & & regulation of transcription, DNA-dependent \\
\hline
\end{tabular}




\begin{tabular}{|c|c|c|c|c|}
\hline Gene & Preditores & Entropia & KEGG & Função Biológica \\
\hline PRKG2 & 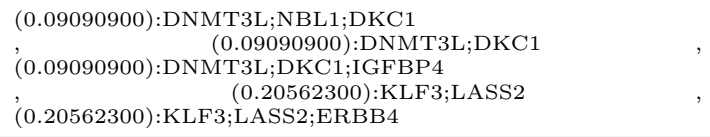 & 0.091 & & regulation of cell cycle \\
\hline ALOX15B & 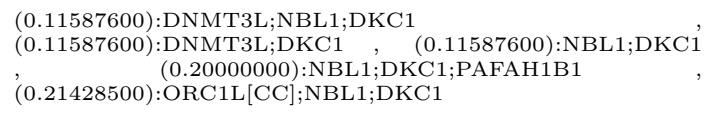 & 0.116 & & negative regulation of cell cycle \\
\hline DLX5 & $\begin{array}{l}(0.11587600): \text { KLF3;CRABP2 }, \quad(0.13333300): \text { CRABP } 2 ; C D 164 \\
\quad(0.15079000): \text { DNMT3L;CD164 },(0.15079000): \text { SIAH2;CD164 } \\
,(0.20000000): \text { DNMT3L;REL;CD164 }\end{array}$ & 0.116 & & regulation of transcription, DNA-dependent \\
\hline DNASE1L2 & $\begin{array}{l}(0.11587600): \text { IRF } 1 ; \text { LASS2 } \quad(0.18254200): \text { IRF } 1 ; \text { TBX21 } \\
\quad(0.18254200): \text { IRF } 1 ; \text { TBX21;LASS2 } \\
(0.20000000): \text { IRF } 1 ; \text { POU1F1;LASS2 } \\
(0.22061900): \text { KLF3;CRABP2 }\end{array}$ & 0.116 & & DNA binding \\
\hline FGF18 & 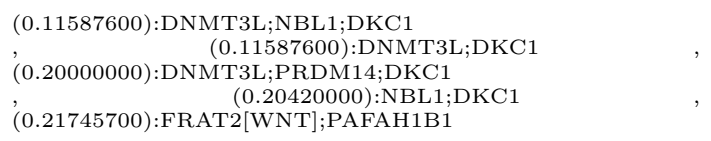 & 0.116 & {$[\mathrm{MAPK}][\mathrm{A}$} & CPLNitive regulation of cell proliferation \\
\hline GAS7 & $\begin{array}{l}(0.11587600): \text { LASS } 2 \text {;PAFAH1B1 } \\
(0.20000000): \text { TBX21;PAFAH1B1;AREG } \\
(0.20316200): \text { KLF3;LASS2 } \quad, \quad(0.22061900): \text { KLF3;CRABP2 } \\
(0.23491400): \text { SIAH2;DKC1 }\end{array}$ & 0.116 & & cell cycle arrest \\
\hline MYF5 & 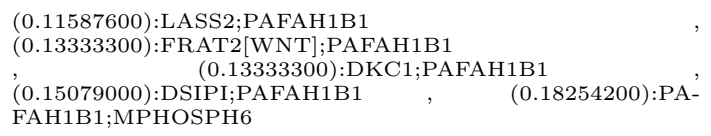 & 0.116 & & DNA binding \\
\hline POU 4F 2 & $\begin{array}{l}(0.11587600): \text { LASS } 2 ; \text { PAFAH1B1 } \\
(0.18254200): \text { POU } 1 \text { F } 1 ; \text { LASS } 2 ; \text { HOXC13 } \\
(0.18254200): \text { KLF3;LASS2 },(0.18254200): \text { LASS } 2 ; \text { HOXC13 } \\
(0.24920900): \text { IRF } 1 ; \text { PAFAH } 1 \text { B } 1\end{array}$ & 0.116 & & regulation of transcription, DNA-dependent \\
\hline SKP2 & $\begin{array}{l}(0.11587600): \text { POU1F1 } \quad(0.11587600): \text { POU1F1;LASS2 } \\
(0.11587600): \text { POU1F1;CD164 },(0.13333300): \text { POU1F1;CCNG2 } \\
,(0.15079000): \text { NFIA;POU1F1 }\end{array}$ & 0.116 & {$[\mathrm{CC}]$} & G1/S transition of mitotic cell cycle \\
\hline PITX3 & 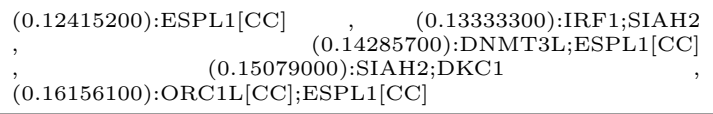 & 0.124 & & regulation of transcription, DNA-dependent \\
\hline SPOCK & 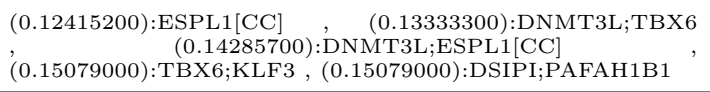 & 0.124 & & cell proliferation \\
\hline TAF4B & $\begin{array}{l}(0.12415200): \text { POU } 1 F 1 ; \mathrm{CD} 164 \\
(0.16156100): \mathrm{REL} ; \mathrm{POU} 1 \mathrm{~F} 1 ; \mathrm{CD} 164 \\
(0.25169400): \mathrm{POU} 1 \mathrm{~F} 1 ; \mathrm{EPAS} 1, \quad(0.26701000): \mathrm{IRF} 1 ; \mathrm{ADNP} \\
(0.26701000): \text { POU } 1 \mathrm{~F} 1 ; \mathrm{LASS} 2 ; \mathrm{CD} 164\end{array}$ & 0.124 & & regulation of transcription, DNA-dependent \\
\hline HOXD10 & $\begin{array}{l}\text { (0.12618500): ORC1L }[\mathrm{CC}] ; \mathrm{ESPL} 1[\mathrm{CC}] \\
(0.18181800): \mathrm{FRAT} 2[\mathrm{WNT}] ; \mathrm{IGFBP} 4 \\
(0.2000000): \text { ORC1L }[\mathrm{CC}] ; \mathrm{POU} 1 \mathrm{~F} 1 ; \mathrm{ESPL} 1[\mathrm{CC}] \\
\quad(0.22942900): \mathrm{TBX} 21 ; \mathrm{FRAT} 2[\mathrm{WNT}] \\
(0.22942900): \mathrm{FRAT} 2[\mathrm{WNT}]\end{array}$ & 0.126 & & regulation of transcription, DNA-dependent \\
\hline
\end{tabular}

Tabela B.2: Tabela com os 38 genes melhores preditos no primeiro passo 


\begin{tabular}{|c|c|c|c|c|}
\hline Gene & Preditores & Entropia & KEGG & Função Biológica \\
\hline ARNT & 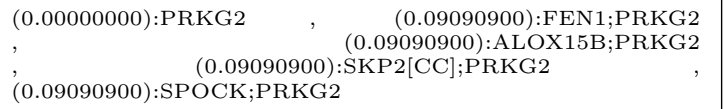 & 0.000 & & regulation of transcription, DNA-dependent \\
\hline DFFB & $\begin{array}{l}(0.00000000): Z N F 20 \quad(0.00000000): Z N F 20 ; G A S 7 \\
(0.08333300): \text { TGFB3[MAPK][CC][CYT][TGF];ZNF20 } \\
(0.08333300): \text { TAF4B;ZNF20 },(0.08333300): \text { ZNF20;FLJ13265 }\end{array}$ & 0.000 & {$[\mathrm{AP}]$} & DNA fragmentation during apoptosis \\
\hline HEYL & 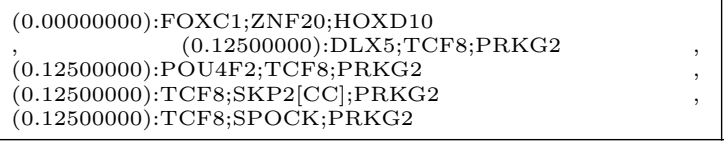 & 0.000 & & regulation of transcription, DNA-dependent \\
\hline IL9R & $\begin{array}{l}(0.00000000): X P C ; P F D N 1 \quad, \quad(0.09090900): P R K G 2 ; F O X D 2 \\
(0.14285700): X P C ; N E U R O D 1 ; P F D N 1,(0.15801200): P R K G 2 \\
,(0.18026500): X P C\end{array}$ & 0.000 & {$[\mathrm{CYT}][\mathrm{JAK}$} & ] cell proliferation \\
\hline NCOA5 & 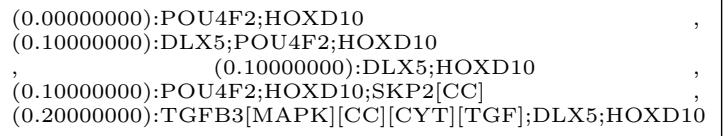 & 0.000 & & regulation of transcription, DNA-dependent \\
\hline PPP1R15A & 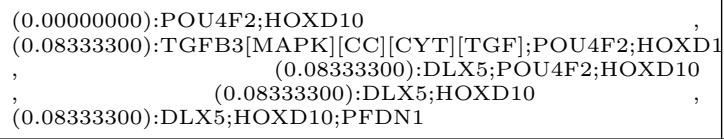 & 0.000 & & cell cycle arrest \\
\hline BUB1B & $\begin{array}{l}(0.06666600): \text { POU4F } 2 ; \text { PFDN1 } \\
(0.08333300): \text { DLX5;HOXD10;PFDN1 } \\
(0.08333300): \text { POU4F } 2 ; \text { HOXD10;PFDN1 } \\
\quad(0.13333300): \text { DLX5; POU4F } 2 ; \text { PFDN1 } \\
(0.13333300): \text { POU4F } 2 ; \text { YAF } 2 ; \text { PFDN1 }\end{array}$ & 0.067 & {$[\mathrm{CC}]$} & cell cycle \\
\hline IRF 5 & $\begin{array}{l}\text { (0.06666600):TGFB3[MAPK][CC][CYT][TGF];ALOX15B } \\
(0.06666600): \text { TGFB3[MAPK][CC][CYT][TGF];ALOX15B;SALL } \\
\quad(0.06666600): A L O X 15 B ; \text { SALL2 } \\
\text { (0.06666600):ALOX15B;SALL2;MYF5 } \\
(0.06666600): \text { ALOX15B;MYF5 }\end{array}$ & 0.067 & & regulation of transcription, DNA-dependent \\
\hline TNFAIP3 & $\begin{array}{l}(0.06666600): \text { FEN1;FLJ13265;SALL2 } \\
(0.14484500): \text { TGFB3[MAPK][CC][CYT][TGF];HOXD10 } \\
(0.16666600): \text { TGFB3[MAPK][CC][CYT][TGF];HOXD10;CDKN } \\
(0.16666600): \text { BHLHB2;POU4F2;HOXD10 },(0.16666600): \text { BH- } \\
\text { LHB }\end{array}$ & $\begin{array}{l}0.067 \\
B[C C]\end{array}$ & & DNA binding \\
\hline ZNF262 & 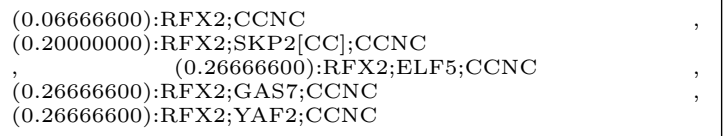 & 0.067 & & DNA binding \\
\hline ZNF75 & $\begin{array}{l}(0.06666600): \text { FEN } 1 ; \text { RFX } 2 \\
(0.12500000): \text { ZNF } 20 ; \text { HOXD10;PRKG } 2 \\
(0.13333300): \text { FEN } 1 ; \text { RFX2;FLJ13265 } \\
(0.20562300): \text { PRKG } 2 ; \text { PER } 2,(0.21745700): \text { FEN } 1 ; \text { PER } 2\end{array}$ & 0.067 & & DNA binding \\
\hline APPL & $\begin{array}{l}(0.07142800): Y A F 2 ; C C N C \\
(0.14285700): S K P 2[C C] ; Y A F 2 ; C C N C, \quad(0.14285700): R A R- \\
\text { RES1;YAF2 },(0.18026500): Y A F 2,(0.19558100): R F X 2 ; Y A F 2\end{array}$ & 0.071 & & cell cycle \\
\hline
\end{tabular}




\begin{tabular}{|c|c|c|c|c|}
\hline Gene & Preditores & Entropia & KEGG & Função Biológica \\
\hline ZNF177 & $\begin{array}{c}(0.07142800): \text { TAF4B;MAPK13[MAPK] [TOLL] } \\
(0.07692300) \text { :TAF4B;TCF8 } \\
(0.07692300): \text { TAF4B;TCF } 8 \text { MAPK13[MAPK] [TOLL] } \\
(0.09090900): \text { PRKG2;PER2 } \\
(0.16666600): \text { FEN1;HOXD10;TCF8 }\end{array}$ & 0.071 & & DNA binding \\
\hline AREG & $\begin{array}{l}(0.07692300): \text { FOXC } 1 \text {;ELF5 } \\
(0.18181800): \text { FEN1;PRKG2;NEUROD1 } \\
(0.18181800): \text { PRKG } 2 ; \text { NEUROD1;PER2 } \\
(0.21745700): \text { ELF5 } 5 \text { SKP2[CC];PFDN1 } \\
(0.22618500): \text { FOXC } 1 ; \text { HOXD10;NEUROD1 }\end{array}$ & 0.077 & & cell proliferation \\
\hline BAZ2B & $\begin{array}{l}\text { (0.08333300):HOXD10;NEUROD1;PFDN1 } \\
(0.1448500): \text { TGFB3[MAPK][CC][CYT][TGF];HOXD10 } \\
(0.16666600): \text { TGFB3[MAPK][C]][CYT][TGF];HOXD10;CDKN } \\
\text { (0.18848800):TGFB3[MAPK][CC][CYT][TGF];POU4F2;HOXD }\end{array}$ & $\begin{array}{l}0.083 \\
\mathrm{~B}[\mathrm{CC}] \\
10\end{array}$ & & DNA binding \\
\hline CDK10 & $\begin{array}{l}(0.08333300): \text { HOXD10;NEUROD1;PFDN1 } \\
(0.16666600): \text { ZFP95;HOXD10;NEUROD1 } \\
\text { (0.18181800):FEN1;PRKG2;NEUROD1 } \\
(0.18181800): \text { HOXD10;TCF19;NEUROD1 } \\
(0.18978500): \text { HOXD10;NEUROD1 }\end{array}$ & 0.083 & & negative regulation of cell proliferation \\
\hline CDK8 & 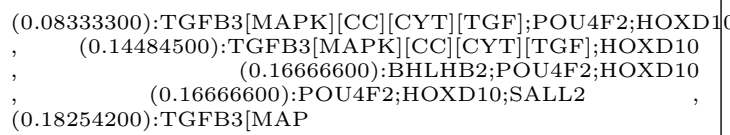 & 0.083 & & regulation of cell cycle \\
\hline ELF4 & $\begin{array}{l}(0.08333300): \text { FEN1;HOXD10 } \\
(0.16666600): \text { FEN1;HOXD10;TCF8 } \\
(0.16666600): \text { FEN1;HOXD10;MAPK13[MAPK] [TOLL] } \\
\quad(0.17398900): \text { TAF4B;TCF8 } \\
(0.17398900): \text { TAF4B;TCF8;MAPK13[MAPK][TOLL] }\end{array}$ & 0.083 & & regulation of transcription, DNA-dependent \\
\hline HES6 & $\begin{array}{c}(0.08333300): \text { FEN1;HOXD10 },(0.10000000): \text { FOXC1;HOXD10 } \\
(0.10000000): \text { FOXC1; HOXD10;NEUROD1 } \\
(0.10515400): \text { ZNF20, }(0.10515400): \text { ZNF20;GAS7 }\end{array}$ & 0.083 & & regulation of transcription, DNA-dependent \\
\hline KIAA1018 & 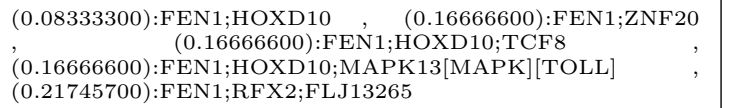 & 0.083 & & DNA binding \\
\hline MTMR7 & $\begin{array}{l}(0.08333300): \text { XPC;RARRES1 } \\
(0.0833300): \text { XPC;RARRES1;FOXD2 } \\
(0.16666600): \text { XPC;RARRES1;NEUROD1 } \\
\quad(0.20000000): \text { XPC;FOXC1;RARRES1 } \\
(0.20000000): \text { DNASE1L } 2 ; \text { FOXC1;RARRES1 }\end{array}$ & 0.083 & & cell cycle \\
\hline MYNN & $\begin{array}{c}(0.08333300): Z N F 20 ; \text { FLJ13265 } \\
(0.08333300): \text { ZNF20;FLJ13265;GAS7 } \\
(0.08333300): \text { ZNF20;FLJ13265;CCNC } \\
(0.08333300): \text { ZNF20;CCNC } \\
(0.15079000): \text { FEN1;ELF5;FGF18[MAPK][ACTIN] }\end{array}$ & 0.083 & & regulation of transcription, DNA-dependent \\
\hline NOTCH4 & $\begin{array}{c}(0.08333300): \text { DLX5;POU4F2;HOXD10 } \\
(0.08333300): \text { DLX5;HOXD10 } \\
(0.08333300): \text { DLX5;HOXD10;PFDN1 } \\
(0.08333300): \text { POU4F2;HOXD10;PFDN1 } \\
(0.16666600): \text { DLX5;ZZP95; HOXD10 }\end{array}$ & 0.083 & & $\begin{array}{l}\text { positive regulation of transcription, DNA- } \\
\text { dependent }\end{array}$ \\
\hline NPAS2 & $\begin{array}{l}(0.08333300): \text { HOXD10;NEUROD1;PFDN1 } \\
(0.1884800): \text { TGFB3[MAPK] [CC][CYT][TGF];ZNF20 } \\
(0.20562300): \text { TGFB3[MAPK][CC][CYT][TGF];ZNF20;TCF19 } \\
,(0.2500000): \text { TGFB3[MAPK] [CC][CYT][TGF];ZNF20;ZFP95 } \\
,(0.2500\end{array}$ & 0.083 & & regulation of transcription, DNA-dependent \\
\hline
\end{tabular}




\begin{tabular}{|c|c|c|c|c|}
\hline Gene & Preditores & Entropia & KEGG & Função Biológica \\
\hline PRM1 & 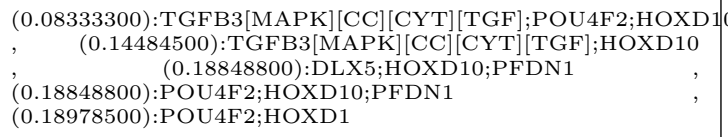 & 0.083 & & DNA binding \\
\hline STAT1 & 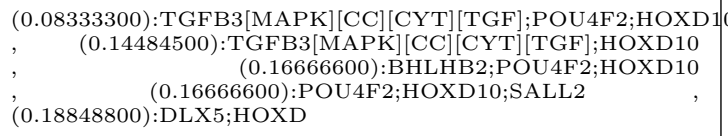 & 0.083 & {$[\mathrm{JAK}][\mathrm{TOI}$} & Lłegulation of cell cycle \\
\hline $\mathrm{SYCP} 2$ & $\begin{array}{l}(0.08333300): \text { HOXD10;NEUROD } 1 ; \text { PFDN1 } \\
(0.24920900): \text { TGFB3[MAPK] [CC][CYT] [TGF];FLJ13265;MYF5 } \\
\quad(0.25000000): \text { TGFB3[MAPK][CC][CYT][TGF];HOXD10 } \\
(0.25000000): \text { TGFB3[MAPK] [CC][CYT][TGF];HOXD10;NEUR } \\
,(\end{array}$ & 0.083 & & DNA binding \\
\hline TACC1 & $\begin{array}{l}(0.08333300): \text { DLX } 5 ; \text { HOXD10;PFDN1 } \\
(0.08333300): \text { POU4F2;HOXD10;PFDN1 } \\
\quad(0.16666600): \text { FEN1;HOXD10;TCF } 8 \\
(0.16666600): \text { FEN1;HOXD10;MAPK13[MAPK] [TOLL] } \\
(0.21745700): \text { ELF5;ALOX15B }\end{array}$ & 0.083 & & cell cycle \\
\hline TAF 12 & 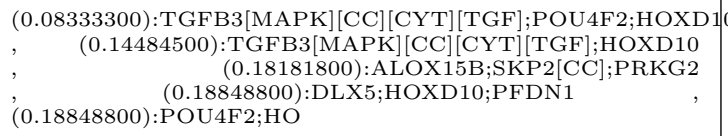 & 0.083 & & DNA binding \\
\hline TIMP1 & $\begin{array}{l}(0.08333300): \text { DLX } 5 ; \text { POU } 4 F 2 ; \text { HOXD } 10 \\
\quad(0.08333300): \text { DLX } 5 ; \text { HOXD } 10 \\
(0.08333300): \text { DLX5;HOXD10;PFDN1 } \\
(0.08333300): \text { POU } 4 F 2 ; \text { HOXD } 10 ; \text { PFDN } 1 \\
(0.08333300): \text { HOXD } 10 ; \text { TCF } 8\end{array}$ & 0.083 & & positive regulation of cell proliferation \\
\hline TXNDC & $\begin{array}{l}(0.08333300): \text { HOXD10;NEUROD1;PFDN1 } \\
(0.25000000): \text { HOXD10;SKP2[CC];NEUROD1 } \\
(0.25525000): \text { HOXD10;NEUROD1 },(0.26589700): \text { TCF } 8 ; \text { GAS7 } \\
,(0.26589700): \text { TCF } 8 ; \text { GAS7;MAPK13[MAPK] [TOLL] }\end{array}$ & 0.083 & & DNA replication \\
\hline VEGFC & 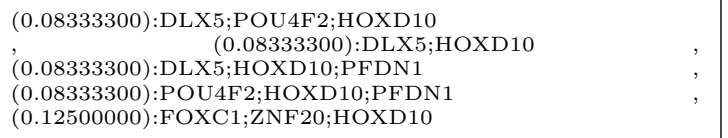 & 0.083 & {$[\mathrm{CYT}]$} & cell proliferation \\
\hline ZNF261 & $\begin{array}{l}(0.08333300): \text { DLX } 5 ; \text { POU 4F } 2 ; \text { HOXD } 10 \\
\quad \quad(0.08333300): \text { DLX5;HOXD10 } \\
(0.08333300): \text { DLX5; HOXD10;PFDN1 } \\
(0.08333300): \text { POU4F } 2 ; \text { HOXD10;PFDN1 } \\
(0.16156100): \text { XPC;RARRES1 }\end{array}$ & 0.083 & & DNA binding \\
\hline BCAR3 & $\begin{array}{l}(0.08412300): \text { FEN1;ELF5 } \quad(0.08412300): \text { DLX5;ELF5 } \\
\quad(0.15079000): \text { FEN1;BHLHB2 } \\
(0.15079000): \text { FEN1;ELF5;FGF18[MAPK][ACTIN] } \\
(0.15079000): \text { DLX5;ELF5;SKP2[CC] }\end{array}$ & 0.084 & & regulation of cell cycle \\
\hline JRK & $\begin{array}{l}(0.08412300): \text { DLX5;YAF2 },(0.15079000): \text { DLX5;YAF } 2 ; \text { PFDN1 } \\
(0.20000000): D L X 5 ; F L J 13265 ; Y A F 2 \\
, \quad(0.21428500): \text { DLX5; YAF2;FOXD2 } \\
(0.21745700): \text { DLX5;POU4F2;YAF2 }\end{array}$ & 0.084 & & DNA binding \\
\hline POU2AF1 & 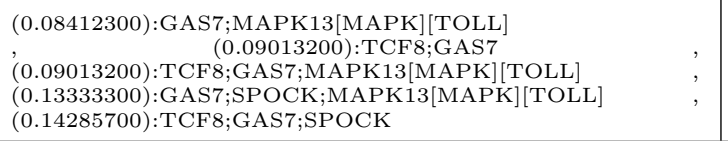 & 0.084 & & regulation of transcription, DNA-dependent \\
\hline RAD1 & $\begin{array}{l}(0.08412300): \text { FEN1; ELF5 } \quad, \quad(0.15079000): \text { FEN1;BHLHB2 } \\
(0.15079000): \text { FEN1;ELF5;FGF18[MAPK][ACTIN] } \\
(0.18254200): \text { FEN1;MYF5 },(0.18848800): \text { FEN1;HOXD10 }\end{array}$ & 0.084 & & DNA repair \\
\hline
\end{tabular}

Tabela B.3: Tabela com os 37 genes melhores preditos no segundo passo 


\begin{tabular}{|c|c|c|c|c|}
\hline Gene & Preditores & Entropia & KEGG & Função Biológica \\
\hline CORT & $\begin{array}{l}(0.00000000): \text { HEYL;NPAS2 } \\
(0.09090900): \text { RAD } 1 ; \text { HEYL;NPAS2 } \\
(0.09090900): \text { BCAR3;HEYL;NPAS2 } \\
(0.18181800): \text { PPP1R15A;HEYL;NPAS2 } \\
(0.18181800): \text { CDK8;HEYL;NPAS2 }\end{array}$ & 0.000 & & DNA binding \\
\hline FANCE & 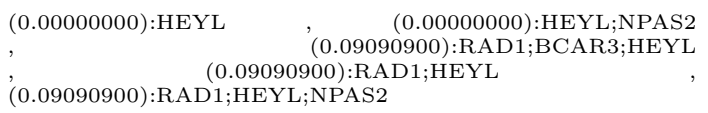 & 0.000 & & DNA repair \\
\hline GABPA & $\begin{array}{l}(0.00000000): \text { HEYL;NPAS2 } \\
(0.09090900): \text { RAD } 1 ; \text { HEYL;NPAS2 } \\
(0.09090900): \text { BCAR3;HEYL;NPAS2 } \\
(0.15079000): \text { POU2AF1;ZNF261;NPAS2 } \\
(0.15079000): \text { BUB1B }[\text { CC }] ; \text { NPAS2 }\end{array}$ & 0.000 & & regulation of transcription, DNA-dependent \\
\hline HAND2 & $\begin{array}{l}(0.00000000): \text { HEYL;NPAS2 } \\
(0.09090900): \text { RAD } 1 \text { HEYL;NPAS2 } \\
(0.09090900): \text { BCAR3;HEYL;NPAS2 } \\
(0.14285700): \text { PPP1R15A;APPL;NPAS2 } \\
(0.14285700): \text { APPL;ZNF261;NPAS2 }\end{array}$ & 0.000 & & DNA binding \\
\hline MGA & 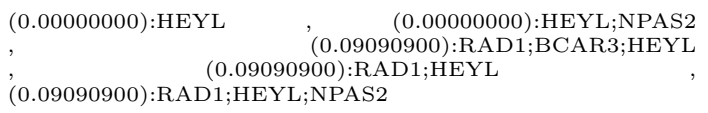 & 0.000 & & regulation of transcription, DNA-dependent \\
\hline $\mathrm{PCBP} 2$ & $\begin{array}{l}(0.00000000): \text { ZNF } 75 ; \text { TNFAIP3 } \\
(0.11111100): \text { TAF } 12 ; \text { MTMR7;TNFAIP3 } \\
(0.11111100): \text { ZNF75;MTMR7;TNFAIP3 } \\
(0.11111100): \text { MTMR7;PPP1R15A;TNFAIP3 } \\
(0.11111100): \text { MTMR } 7 \text {;CDK8;TNFAIP3 }\end{array}$ & 0.000 & & DNA binding \\
\hline ZNF337 & 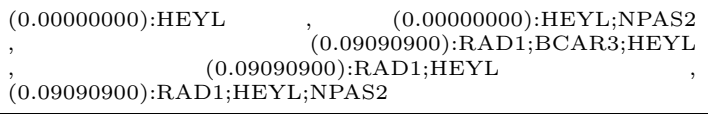 & 0.000 & & DNA binding \\
\hline $\mathrm{ACPP}$ & 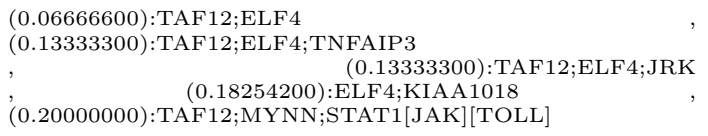 & 0.067 & & regulation of cell cycle \\
\hline BLM & 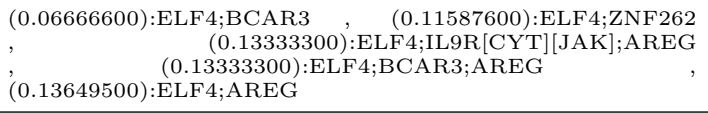 & 0.067 & & ATP-dependent DNA helicase activity \\
\hline FLJ13265 & $\begin{array}{c}(0.06666600): \text { RAD1;AREG } \quad(0.11587600): \text { ARNT;RAD1 } \\
\quad(0.13333300): M Y N N ; R A D 1 ; A R E G \\
\begin{array}{c}(0.13333300): \text { TACC1;RAD1;AREG } \\
(0.1333300): R A D 1 ; B C A R 3 ; A R E G\end{array}\end{array}$ & 0.067 & & regulation of cell cycle \\
\hline NUP153 & 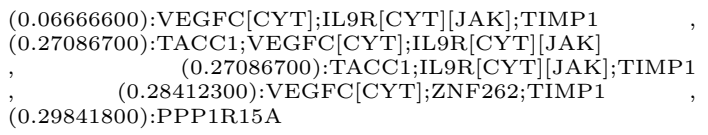 & 0.067 & & DNA binding \\
\hline PFDN1 & $\begin{array}{l}(0.06666600): \text { BUB1B }[C C] ; \text { NPAS2 }, \quad(0.11471400): \text { HEYL } \\
(0.11471400): \text { HEYL;NPAS2 }, \quad(0.11587600): \text { TXNDC;NPAS2 } \\
(0.15079000): \text { :TXNDC;ZNF261 }\end{array}$ & 0.067 & & cell cycle \\
\hline
\end{tabular}




\begin{tabular}{|c|c|c|c|c|}
\hline Gene & Preditores & Entropia & KEGG & Função Biológica \\
\hline POLR3K & $\begin{array}{l}\text { (0.06666600):ZNF75;ARNT } \\
(0.07692300): \text { ARNT;VEGFC[CYT];NCOA5 } \\
\quad(0.07692300): A R N T ; N C O A 5 \\
\text { (0.13333300):SYCP2;ARNT;HES6 } \\
\text { (0.13333300):ARNT;CDK10;HES6 }\end{array}$ & 0.067 & & DNA-directed RNA polymerase III complex \\
\hline SPOCK & 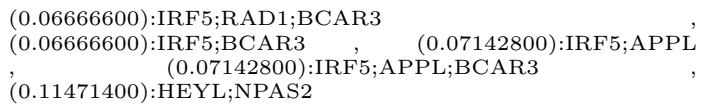 & 0.067 & & cell proliferation \\
\hline WHSC2 & $\begin{array}{l}(0.06666600): Z N F 177 ; \text { HES6 } \quad, \quad(0.11471400): \text { HEYL;NPAS2 } \\
\text { (0.18181800):PPP1R15A;CDK8;HEYL } \\
(0.18181800): \text { PPP1R15A;ZNF261;HEYL }\end{array}$ & 0.067 & & regulation of transcription, DNA-dependent \\
\hline ZNF10 & $\begin{array}{l}(0.06666600): \text { POU2AF1;SYCP2 } \\
(0.08412300): \text { POU2AF } 1 ; \text { NPAS2 } \\
(0.11471400): \text { HEYL } \quad(0.11471400): \text { HEYL;NPAS2 } \\
(0.1333300): \text { POU } 2 A F 1 ; \text { STAT1[JAK] [TOLL] }\end{array}$ & 0.067 & & DNA binding \\
\hline ZNF8 & $\begin{array}{l}(0.06666600): \text { BAZ2B;SYCP2 } \\
(0.06666600): \text { BAZ2B;SYCP2;NPAS2 } \\
(0.06666600): \text { SYCP2;TXNDC;NPAS2 } \\
(0.06666600): \text { SYCP2;NPAS2 },(0.11587600): \text { SYCP } 2 ; \text { TNFAIP } 3\end{array}$ & 0.067 & & DNA binding \\
\hline CTNNBIP1 & $\begin{array}{l}(0.07142800): \text { TAF } 12 ; \text { APPL } \quad, \quad(0.14285700): P P P 1 R 15 A ; A P P L \\
(0.14285700): P P P 1 R 15 A ; A P P L ; Z N F 261 \\
(0.14285700): P P P 1 R 15 A ; A P P L ; N P A S 2 \\
(0.14285700): P P P 1 R 15 A ; A P P L ; P R M 1\end{array}$ & 0.071 & {$[\mathrm{WNT}]$} & cell proliferation \\
\hline ESRRG & 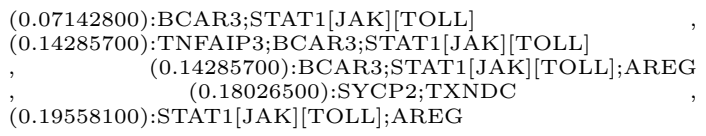 & 0.071 & & $\begin{array}{l}\text { positive regulation of transcription, DNA- } \\
\text { dependent }\end{array}$ \\
\hline MEOX1 & 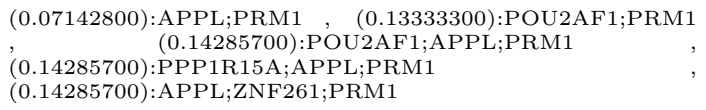 & 0.071 & & regulation of transcription, DNA-dependent \\
\hline NCOA6 & $\begin{array}{l}(0.07142800): \text { TAF } 12 ; \text { APPL } \quad(0.11471400): \text { HEYL;NPAS2 } \\
\quad(0.18181800): \text { HEYL;NOTCH4;NPAS2 } \\
\text { (0.20000000):TAF12;TNFAIP3 } \\
(0.20000000): \text { SYCP } 2 ; \text { MTMR7;APPL }\end{array}$ & 0.071 & & DNA recombination \\
\hline $\mathrm{NR} 2 \mathrm{~F} 1$ & 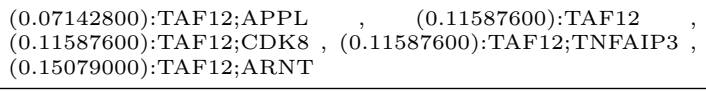 & 0.071 & & regulation of transcription, DNA-dependent \\
\hline PLCE1 & $\begin{array}{l}(0.07142800): \text { IRF5;APPL },(0.07142800): \text { IRF } 5 ; A P P L ; B C A R 3 \\
(0.11471400): \text { HEYL;NPAS2, }(0.14285700): \text { IRF5;APPL;HES6 } \\
(0.18181800): \text { HEYL;NOTCH4;NPAS2 }\end{array}$ & 0.071 & & cell proliferation \\
\hline PPP1R15A & $\begin{array}{l}(0.07142800): \text { TAF } 12 ; \text { APPL } \\
\quad(0.11587600): \text { TAF12 } \\
(0.11587600): \text { TAF12;TNFAIP3 }\end{array}$ & 0.071 & & cell cycle arrest \\
\hline RPS6KA4 & $\begin{array}{l}(0.07142800): \text { IRF } 5 ; A P P L,(0.07142800): \text { IRF } 5 ; \text { APPL;BCAR3 } \\
(0.11471400): \text { HEYL;NPAS2 },(0.14285700): \text { IRF } 5 ; \text { APPL;HES6 } \\
(0.18181800): \text { HEYL;NOTCH4;NPAS2 }\end{array}$ & 0.071 & {$[\mathrm{MAPK}]$} & regulation of transcription, DNA-dependent \\
\hline
\end{tabular}




\begin{tabular}{|c|c|c|c|c|}
\hline Gene & Preditores & Entropia & KEGG & Função Biológica \\
\hline SMCY & $\begin{array}{l}(0.07142800): \text { IRF } 5 ; \text { APPL },(0.07142800): \text { IRF 5;APPL;BCAR3 } \\
(0.11471400): \text { HEYL;NPAS2, (0.14285700):IRF5;APPL;HES6 } \\
(0.18181800): \text { HEYL;NOTCH4;NPAS2 }\end{array}$ & 0.071 & & DNA binding \\
\hline SOX 4 & $\begin{array}{l}(0.07142800): \text { IRF } 5 ; \text { APPL }, \quad(0.07142800): \text { IRF } 5 ; \text { APPL;BCAR3 } \\
\quad(0.14285700): \text { IRF5;APPL;HES6 } \\
(0.14285700): \text { PPP1R15A;APPL;NPAS2 } \\
(0.14285700): \text { APPL;ZNF 261;NPAS2 }\end{array}$ & 0.071 & & regulation of transcription, DNA-dependent \\
\hline TGFBI & $\begin{array}{l}(0.07142800): \text { IRF } 5 ; \text { APPL },(0.07142800): \text { IRF 5;APPL;BCAR3 } \\
(0.11471400): \text { HEYL;NPAS2, (0.14285700):IRF5;APPL;HES6 } \\
(0.18181800): \text { HEYL;NOTCH4;NPAS2 }\end{array}$ & 0.071 & & cell proliferation \\
\hline $\mathrm{XRCC} 4$ & $\begin{array}{l}(0.07142800): \text { SYCP } 2 ; \text { TNFAIP } 3 ; \text { HES6 } \\
\quad(0.12415200): \text { SYCP } 2 ; \text { TNFAIP3 } \\
(0.22618500): \text { TAF } 12 ; \text { MTMR } 7 \text { CDK8 } \\
(0.22618500): \text { MTMR7;PPP1R15A;CDK8 } \\
(0.22618500): \text { MTMR } 7 \text { CDK8 }\end{array}$ & 0.071 & & DNA recombination \\
\hline POLG & $\begin{array}{l}(0.07692300): \text { TACC } 1 ; \text { NCOA } 5 \\
(0.15079000): \text { SYCP } 2 ; \text { TNFAIP } 3 ; \text { HES6 } 6 \\
(0.15079000): \text { CDK } 8 ; \text { TNFAIP } 3 ; \text { HES6 } \\
(0.15079000): \text { CDK } 8 ; \text { HES } 6,(0.15079000): \text { TNFAIP } 3 ; \text { HES6 }\end{array}$ & 0.077 & & DNA binding \\
\hline $\mathrm{PTN}$ & $\begin{array}{l}(0.07692300): \text { TACC1;NCOA5 } \\
(0.13333300): \text { MYNN;PPP1R15A;TACC1 } \\
(0.13333300): \text { MYNN;TACC1;IL9R[CYT][JAK] } \\
\text { (0.13333300):ZNF75;HES6;KIAA1018 } \\
(0.13333300): \text { ZNF75;KIAA1018 }\end{array}$ & 0.077 & & cell proliferation \\
\hline SPO11 & $\begin{array}{l}(0.07692300): \text { SYCP } 2 ; \text { TXNDC;HES6 } \\
(0.07692300): \text { SYCP } 2 ; \text { CDK10;HES6 } \\
(0.07692300): \text { SYCP } 2 ; \text { TNFAIP3;HES6 } \\
(0.07692300): \text { SYCP } 2 ; \text { HES },(0.07692300): Z N F 177 ; \text { HES } 6\end{array}$ & 0.077 & & DNA binding \\
\hline TNFSF 4 & $\begin{array}{l}(0.07692300): \text { TACC } 1 ; \text { BUB1B [CC];TNFAIP3 } \\
(0.15384600): \text { TAF12;TNFAIP3;STAT1[JAK] [TOLL] } \\
\quad(0.15384600): \text { VEGFC[CYT];CDK8;TNFAIP3 } \\
(0.15384600): \text { CDK8;TNFAIP3;STAT1[JAK][TOLL] } \\
(0.21062600): \text { PPP1R15A;VEGFC }\end{array}$ & 0.077 & {$[\mathrm{CYT}]$} & positive regulation of cell proliferation \\
\hline TNP2 & $\begin{array}{l}(0.07692300): \text { TACC } 1 ; \text { NCOA5 } \\
(0.15384600): \text { MYNN;TACC1;NCOA5 } \\
(0.15384600): \text { TACC } 1 ; \text { VEGFC[CYT];NCOA5 } \\
(0.15384600): \text { TACC } 1 ; \text { IL9R[CYT][JAK];NCOA5 } \\
(0.16666600): \text { ARNT;APPL;NCOA5 }\end{array}$ & 0.077 & & DNA binding \\
\hline ZNF7 & $\begin{array}{l}(0.07692300): \text { APPL;PRM1 , } \quad(0.14285700): \text { POU2AF1;PRM1 } \\
\quad \quad(0.15384600): \text { POU2AF1;APPL;PRM1 } \\
(0.18181800): \text { PPP1R15A;HEYL;PRM1 } \\
(0.18181800): \text { CDK8;HEYL;PRM1 }\end{array}$ & 0.077 & & DNA binding \\
\hline NCOA5 & $\begin{array}{l}(0.08333300): \mathrm{TACC} 1 ; \mathrm{APPL} \quad, \quad(0.09706600): \mathrm{TAF} 12 ; \mathrm{TXNDC} \\
\quad(0.15384600): \mathrm{TACC} 1 ; \mathrm{BUB} 1 \mathrm{~B}[\mathrm{CC}] \\
, \quad(0.16666600): \text { IRF } 5 \text { TACC } 1 ; \mathrm{APPL} \\
(0.16666600): \mathrm{TACC} 1 ; \mathrm{APPL} ; \mathrm{BCAR3}\end{array}$ & 0.083 & & regulation of transcription, DNA-dependent \\
\hline FGF1 & 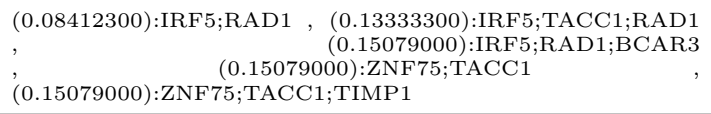 & 0.084 & {$[\mathrm{MAPK}][\mathrm{A}$} & $\mathrm{CE} \Phi \mathrm{N}]$ proliferation \\
\hline $\mathrm{PCBP} 4$ & $\begin{array}{l}(0.08412300): \text { TXNDC;NPAS2 } \\
(0.15079000): \text { SYCP } 2 ; \text { TXNDC;CDK10 } \\
, \quad(0.15079000): \text { SYCP } 2 ; \text { TXNDC;NPAS2 } \\
, \quad(0.15079000): \text { TXNDC;CDK10 } \\
(0.15079000): \text { TXNDC;CDK10;HES6 }\end{array}$ & 0.084 & & DNA binding \\
\hline
\end{tabular}

Tabela B.4: Tabela com os 38 genes melhores preditos no terceiro passo 


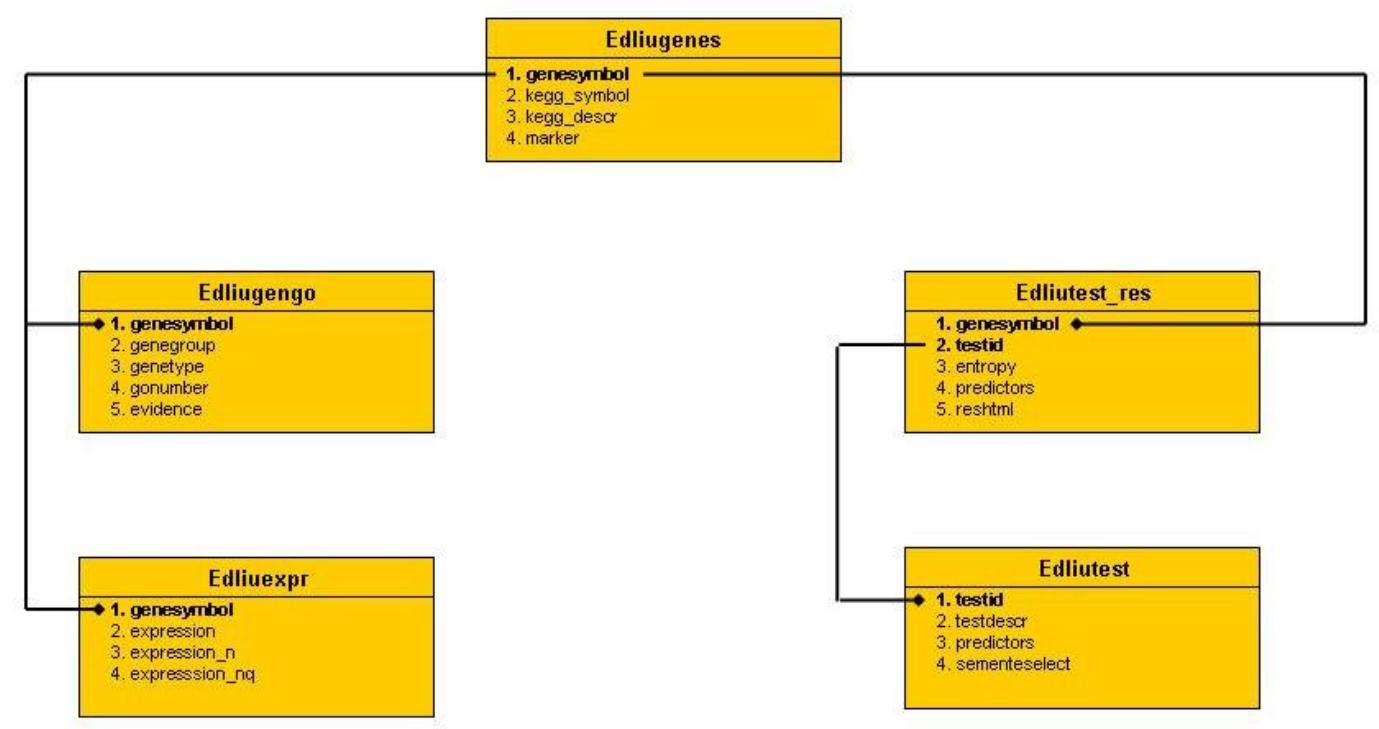

Figura B.1: Representação esquemática do banco de dados 
Apêndice C

Adesão celular 
A Tabela C.1 contém os 235 genes melhores preditos (custo < 0.08) pelo conjunto de 53 genes-sementes contidos na Tabela 5.1. A coluna preditores indica os melhores 5 conjuntos preditores para cada gene.

\begin{tabular}{|c|c|c|c|c|}
\hline Gene & Preditores & Entropia & KEGG & Função Biológica \\
\hline B4GALT2 & $\begin{array}{ll}\text { (0.00000000): } \text { SCN1B;GREB1, } & (0.06666600): \text { NIF3L1;GREB1, } \\
(0.06666600): G R E B 1 ; C D 7, & (0.13333300): \text { NOL5A;GREB1, } \\
(0.15079000): \text { NOL5A;CTSD } & \end{array}$ & 0.000 & & carbohydrate metabolism \\
\hline $\mathrm{C} 8 \mathrm{G}$ & $\begin{array}{l}(0.00000000): \text { NRIP } 1 ; \text { PTGES, } \\
\text { GES;STC2, } \quad(0.06666600): \text { NRIP } 1 ; \text { PTGES;IGFBP4, } \\
(0.06666600): \text { NRIP } 1 ; \text { PTGES;STC2, } \\
(0.06666600): \text { NRIP } 1 ; \text { IGFBP4 }\end{array}$ & 0.000 & & complement activation, alternative pathway \\
\hline CDH16 & $\begin{array}{l}(0.00000000): A L O X 12 B, \quad(0.07692300): \text { NRIP1;ALOX12B, } \\
(0.07692300): F 10 ; A L O X 12 B, \quad(0.07692300): A M D 1 ; A L O X 12 B, \\
(0.07692300): \text { PTGES;ALOX12B }\end{array}$ & 0.000 & & cell adhesion \\
\hline ERG & 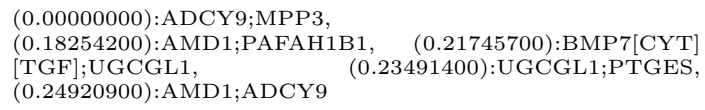 & 0.000 & & cell proliferation \\
\hline HGNT-IV-H & $\begin{array}{l}(0.00000000): \text { CISH[JAK];FLJ } 13710, \\
(0.09090900): \text { CISH[JAK];FLJ13710;HIG2, } \\
(0.09090900): \text { STC2;FLJ13710;HIG } 2 \\
(0.09090900): \text { FLJ } 13710 ; \text { HIG2, } \\
(0.15801200): \text { AMD } 1 ; \text { CISH }[J A K]\end{array}$ & 0.000 & & carbohydrate metabolism \\
\hline SFRS6 & $\begin{array}{lr}\text { (0.00000000): } \mathrm{MPP} 3 ; \mathrm{KCNG} 1, & (0.13333300): \mathrm{HSPC} 111 ; \mathrm{MPP} 3 \\
(0.13333300): \mathrm{CTSD} \text {; } & (0.13333300): \mathrm{F} 10 ; \text { OLFM1, } \\
(0.13333300): \mathrm{F} 10 ; \mathrm{PAFAH} 1 \mathrm{~B} 1 & \end{array}$ & 0.000 & & mRNA splice site selection \\
\hline CLDN18 & 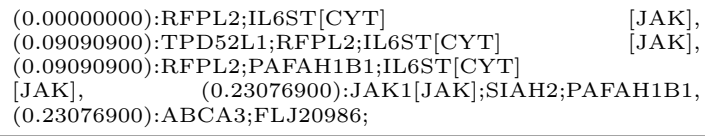 & 0.000 & & calcium-independent cell-cell adhesion \\
\hline L1CAM & $\begin{array}{l}(0.00000000): A L O X 12 B, \quad(0.07692300): \text { NRIP1;ALOX12B, } \\
(0.07692300): F 10 ; A L O X 12 B, \quad(0.07692300): A M D 1 ; A L O X 12 B \\
(0.07692300): \text { PTGES;ALOX12B }\end{array}$ & 0.000 & & cell adhesion \\
\hline PES1 & $\begin{array}{l}\text { (0.00000000):SCN1B;GREB1, } \quad(0.06666600): \text { GREB1;CD7, } \\
(0.13333300): \text { SIAH2;SCN1B, } \quad(0.13333300): \text { FLJ20986;SCN1B, } \\
(0.13333300): \text { SCN1B;CD7 }\end{array}$ & 0.000 & & cell proliferation \\
\hline MCM6 & $\begin{array}{l}(0.00000000): \text { NRIP } 1 ; \text { PTGES, } \\
(0.06666600): \text { NRIP } 1 ; \text { PTGES;IGFBP } 4 \\
(0.06666600): \text { NRIP } 1 ; \text { PTGES;STC } 2 \\
(0.15079000): \text { UGCGL } 1 ; \text { PTGES, } \\
(0.17398900): \text { NRIP } 1 ; \text { ALOX } 12 B\end{array}$ & 0.000 & {$[\mathrm{CC}]$} & DNA replication \\
\hline $\mathrm{ABCB} 8$ & $\begin{array}{l}(0.00000000): \text { LOR;BRI3BP, } \\
(0.09090900): \text { AFG3L2;LOR;BRI3BP, } \\
(0.15801200) \text { :AFG3L2;BRIBBP, }(0.16666600) \text { : NOL5A;LOR, } \\
(0.18181800): \text { NOL5A;LOR;BRI3BP }\end{array}$ & 0.000 & & transport \\
\hline $\mathrm{CDH} 17$ & $\begin{array}{l}(0.00000000): \text { CAP350;BRI3BP, } \\
(0.07692300): \text { F10;BRI3BP, } \quad(0.07692300): \text { PTGES;BRI3BP, } \\
(0.07692300): A F G 3 L 2 ; \text { PAFAH1B1;BRI3BP }\end{array}$ & 0.000 & & cell adhesion \\
\hline
\end{tabular}




\begin{tabular}{|c|c|c|c|c|}
\hline Gene & Preditores & Entropia & KEGG & Função Biológica \\
\hline FAP & $\begin{array}{l}(0.00000000): \text { CENTG1; SERPINE } 1, \\
(0.21428500): \text { CENTG1;SERPINE } 1 \text {;EPHA } 4, \\
(0.21428500): \text { CENTG1;SERPINE1;PGR, } \\
(0.24830500): \text { CENTG } 1,(0.25169400): \text { CENTG1;CRABP } 2\end{array}$ & 0.000 & & cell-cell signaling \\
\hline MAP3K1 & $\begin{array}{ll}(0.00000000): S C N 1 B ; G R E B 1, & (0.06666600): \text { NIF3L1;GREB1, } \\
(0.06666600): G R E B 1 ; C D 7, & (0.13333300): \text { NOL5A;GREB1, } \\
(0.15079000): \text { NOL5A;CTSD } & \end{array}$ & 0.000 & $\begin{array}{l}{[\mathrm{MAPK}]} \\
{[\mathrm{AP}]} \\
{[\mathrm{TCELL}]}\end{array}$ & protein amino acid phosphorylation \\
\hline KIAA1463 & $\begin{array}{l}(0.06666600): \text { :CTBS;ELOVL2;CCNG2, } \\
(0.11587600) \text { :CTBS;ELOVL2, } \\
(0.13333300): \text { CTBS; } \text { LMCD1;ELOVL2, } \\
(0.13649500): \text { :CTBS;CCNG2, } \\
(0.15079000): \text { CTBS;CCNG2;CRABP2 }\end{array}$ & 0.067 & & metabolism \\
\hline JRKL & $\begin{array}{l}(0.06666600): \text { PTGES;ADCY9, } \quad(0.20000000): \text { F10;ADCY } 9 \\
(0.2000000): \text { PTGES;LMCD1;ADCY9, } \\
(0.21745700): \text { RBBP8;ADCY9, }(0.21745700): \text { ADCY9;IGFBP4 }\end{array}$ & 0.067 & & central nervous system development \\
\hline AKR1C4 & $\begin{array}{l}\text { (0.06666600): CCNG } 2 ; \mathrm{LOR} ; \mathrm{CRABP} 2, \\
(0.06666600): \mathrm{LOR} ; \mathrm{CR} \text { ABP2, } \\
(0.11587600): \mathrm{ELOVL} 2 ; \mathrm{LOR}, \quad(0.11587600): \mathrm{CCNG} 2 ; \mathrm{LOR}, \\
(0.13333300): \mathrm{ELOVL} 2 ; \mathrm{LOR} ; \mathrm{CRABP} 2\end{array}$ & 0.067 & & androgen metabolism \\
\hline GUCA1B & 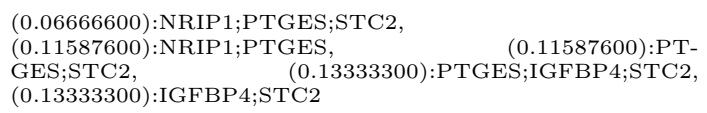 & 0.067 & & cell-cell signaling \\
\hline DELGEF & $\begin{array}{l}(0.06666600): \text { GREB1;CD7, } \quad(0.11587600): \text { SCN1B;GREB1, } \\
(0.2000000): \text { RBBP8;SCN1B, } \\
(0.21062600): \text { FLJ13710;ALOX12B } \\
(0.21745700): \text { SIAH2;SCN1B }\end{array}$ & 0.067 & & signal transduction \\
\hline ADRA2B & 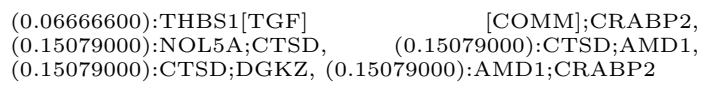 & 0.067 & & $\begin{array}{l}\text { G-protein coupled receptor protein signaling } \\
\text { pathway }\end{array}$ \\
\hline $\mathrm{MX} 2$ & $\begin{array}{l}(0.06666600): \text { LOR;THBS1[TGF] } \\
{[0.08412300): \text { RBBP8;NOL5A, }} \\
(0.13333300): \text { RBBP8;NOL5A;DGKZ, } \\
(0.13333300): \text { RBBP8;LMCD1;EPHA4, } \\
(0.13333300): \text { LMCD } 1 \text {;EPHA4 }\end{array}$ & 0.067 & & immune response \\
\hline OSBPL2 & $\begin{array}{l}(0.06666600): \text { CTSD;AMD1, } \quad(0.26666600): \text { CENTG1;SIAH2, } \\
(0.26666600): J A K 1[J A K] ; C T S D ; A M D 1, \\
(0.26666600): A M D 1 ; P G R ; K C N G 1, \\
(0.26666600): \text { AMD1;CRABP2 }\end{array}$ & 0.067 & & lipid transport \\
\hline HLA-DPA1 & $\begin{array}{l}(0.06666600): \text { HSPC111;NRIP1, } \\
(0.13333300): \text { HSPC111;UGCGL1, } \\
(0.15079000): \text { CENTG1;SIAH2, } \\
(0.15079000): \text { JAK1[JAK];GREB1, } \quad(0.16156100): \text { IL6ST[CYT] } \\
\text { [JAK];BRI3BP }\end{array}$ & 0.067 & & antigen presentation, exogenous antigen \\
\hline FUT6 & 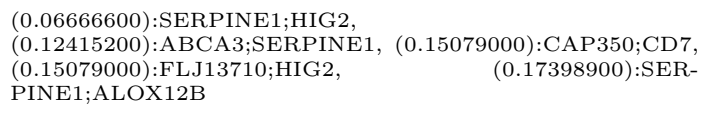 & 0.067 & & L-fucose catabolism \\
\hline BAT8 & $\begin{array}{l}(0.06666600): \text { JAK1[JAK];PAFAH1B1, } \\
(0.0666600): \text { PAFAH1B1;GALNT4, } \\
(0.13333300): J A K 1[\text { JAK];GREB1;PAFAH1B1, } \\
(0.14285700): \text { HSPC111;TPD52L1;IL6ST[CYT] } \\
(0.18254200): \text { HSPC111;IL6ST[CYT] [JAK] }\end{array}$ & 0.067 & & chromatin modification \\
\hline MASA & $\begin{array}{l}(0.06666600): \text { F10;FLJ20986, } \\
(0.13333300): \text { F10;FLJ20986;IGFBP4, } \\
(0.20000000): F 10 ; F L J 20986 ; \text { SLC38A1, } \quad(0.23491400): \text { PT- } \\
\text { GES;FLJ20986, }(0.25169400): \text { F10;TPD52L1 }\end{array}$ & 0.067 & & metabolism \\
\hline
\end{tabular}




\begin{tabular}{|c|c|c|c|c|}
\hline Gene & Preditores & Entropia & KEGG & Função Biológica \\
\hline CENTB2 & $\begin{array}{l}(0.06666600): \mathrm{HSPC} 111 ; \mathrm{IL6ST}[\mathrm{CYT}] \\
\begin{array}{l}\text { [JAK] } \\
(0.11587600): \mathrm{HSPC} 111,\end{array} \quad(0.1333330600): \mathrm{HSPC} 111 ; \mathrm{IGSF} 4, \\
(0.13333300): \mathrm{HSPC} 111 ; \mathrm{RBBP} 8 ; \mathrm{DGKZ}\end{array}$ & 0.067 & & regulation of GTPase activity \\
\hline GYS1 & $\begin{array}{l}(0.06666600): \text { NIF3L } 1 ; \text { CTSD }, \quad(0.15079000): \text { NIF3L1;GREB1, } \\
(0.20316200): \text { NRIP } 1 ; \text { LOR, } \quad(0.23076900): \text { NRIP } 1 ; R F P L 2, \\
(0.23076900): \text { NRIP } 1 ; \text { RFPL } 2 ; \text { KCNG1 }\end{array}$ & 0.067 & & glycogen biosynthesis \\
\hline NIT2 & $\begin{array}{l}\text { (0.06666600): JAK1[JAK];AMD1, } \\
(0.20000000): \text { JAK1[JAK];AMD1;ELOVL2, } \\
(0.21062600): \text { AMD1;ALOX12B, } \\
(0.21745700): \text { GREB } 1 ; \text { IL6ST[CYT] } \\
(0.23491400): \text { F10;FLJ20986 }\end{array}$ & 0.067 & & nitrogen compound metabolism \\
\hline GUCY2D & $\begin{array}{l}(0.06666600): \text { SIAH2;STC2, } \quad(0.15079000): \text { ADCY9;GALNT4, } \\
(0.15384600): \text { SIAH2;RFPL2;STC2, }(0.20000000): \text { BMP7[CYT] } \\
\text { [TGF];EPHA4, }(0.21062600): \text { RFPL2;STC2 }\end{array}$ & 0.067 & & cGMP biosynthesis \\
\hline CCNT2 & $\begin{array}{l}(0.06666600): \text { NRIP } 1 ; \text { PTGES;STC2, } \\
(0.06666600): \text { NRIP1;STC2, } \quad(0.15079000): R B B P 8 ; C A P 350, \\
(0.16824700): \text { NRIP1;PTGES, }(0.16824700): \text { PTGES;STC2 }\end{array}$ & 0.067 & & cytokinesis \\
\hline FLJ20485 & $\begin{array}{l}\text { (0.06666600):AMD1;CRABP2, } \\
(0.14285700): A M D 1 ; A B C A 3, \quad(0.14285700): A B C A 3 ; O L F M 1, \\
(0.20316200): \text { CTSD;THBS1[TGF] } \\
(0.21428500): \text { CTSD;ABCA3;THBS1[TGF] [COMM] }\end{array}$ & 0.067 & & tRNA processing \\
\hline $\mathrm{HGF}$ & $\begin{array}{l}(0.06666600): \text { NFIA;PAFAH1B1, } \\
(0.06666600): \text { FLJ20986;SERPINE1, } \\
(0.06666600): \text { FLJ20986;SERPINE1;EPHA4, } \\
(0.06666600): \text { FLJ20986;SLC38A1, } \\
(0.06666600): \text { GREB } 1 ; \text { SLC38A1 }\end{array}$ & 0.067 & {$[\mathrm{CYT}]$} & mitosis \\
\hline ESRRB & $\begin{array}{l}(0.06666600): \text { SCN1B;GALNT4, } \quad(0.16824700): \text { CTBS;NOL5A, } \\
(0.20000000): \text { SCN1B;GALNT4;KCNG1, } \\
(0.21745700): \text { CTBS;LMCD1;ELOVL2 } \\
(0.21745700): \text { SCN1B;DGKZ }\end{array}$ & 0.067 & & regulation of transcription, DNA-dependent \\
\hline BNIP3L & $\begin{array}{l}(0.06666600): \text { FLJ20986;SLC38A1, } \\
(0.15079000): \text { NIF3L1;GREB1, } \quad(0.15079000): F 10 ; \text { FLJ20986, } \\
(0.18254200): \text { GREB1;PAFAH1B1, } \\
(0.2000000): \text { F10;FLJ20986;SLC38A1 }\end{array}$ & 0.067 & & apoptosis \\
\hline $\mathrm{ZFX}$ & $\begin{array}{l}(0.06666600): \text { CENTG1;SIAH2, } \\
(0.21062600): \text { AMD } 1 ; \text { ALOX12B, } \\
(0.21428500): \text { CENTG1;TPD52L } 1, \\
(0.23491400): \text { SIAH2;CAP350;IGFBP4, } \\
(0.24920900): \text { NIF3L } 1 ; \text { DGKZ }\end{array}$ & 0.067 & & regulation of transcription \\
\hline CIDEB & $\begin{array}{l}\text { (0.06666600): JAK1[JAK];AMD1, } \\
(0.20000000): \text { JAK1[JAK];AMD1;ELOVL2, } \\
(0.21745700): \text { BMP7[CYT] } \\
(0.26666600): \text { JAK1 [JAK];CTSD;AMD1, } \\
(0.26666600): \text { JAK1[JAK];AMD1;CCNG } 2\end{array}$ & 0.067 & & $\begin{array}{l}\text { DNA damage response, signal transduction } \\
\text { resulting in induction of apoptosis }\end{array}$ \\
\hline NFATC4 & $\begin{array}{l}(0.06666600): \text { FLJ20986;SLC38A1, } \\
(0.06666600): \text { GREB1;SLC38A1, } \\
(0.13333300): \text { HSPC111;OLFM1, } \\
(0.1333300): \text { HSPC111;MPP3, } \\
{[\text { COMM];PAFAH1B1 }}\end{array}$ & 0.067 & $\begin{array}{l}{[\mathrm{MAPK}]} \\
{[\mathrm{WNT}]} \\
{[\mathrm{KILL}]} \\
{[\mathrm{TCELL}]}\end{array}$ & inflammatory response \\
\hline SPOCK & $\begin{array}{l}(0.06666600): \text { CTSD;DGKZ, } \quad(0.08412300): C T B S ; N O L 5 A \\
(0.11587600): D G K Z, \quad(0.13333300): C T B S ; N O L 5 A ; D G K Z \\
(0.13333300): \text { CTBS;DGKZ }\end{array}$ & 0.067 & & cell adhesion \\
\hline MRPL4 & $\begin{array}{l}(0.06666600): \text { NRIP } 1 ; \text { PTGES;IGFBP } 4 \\
(0.11587600): \text { NRIP } 1 ; \text { PTGES, } \\
(0.13333300): \text { RBBP } 8 \text { F } 10 ; \text { PTGES, } \quad(0.13333300): \text { F10;PTGES, } \\
(0.13333300): \text { F10;PTGES;IGFBP4 }\end{array}$ & 0.067 & & protein biosynthesis \\
\hline
\end{tabular}




\begin{tabular}{|c|c|c|c|c|}
\hline Gene & Preditores & Entropia & KEGG & Função Biológica \\
\hline CSPG2 & $\begin{array}{l}(0.06666600): \text { NIF3L1;GREB1, }(0.18254200): \text { NIF3L1;ADCY } 9, \\
(0.2000000): \text { NIF3L1; FLJ13710, } \\
(0.2000000): \text { NIF3L1;KCNG1, } \\
(0.20000000): \text { LMCD } 1 ; \text { PAFAH1B } 1 ; \text { STC2 }\end{array}$ & 0.067 & & cell recognition \\
\hline KIFAP3 & 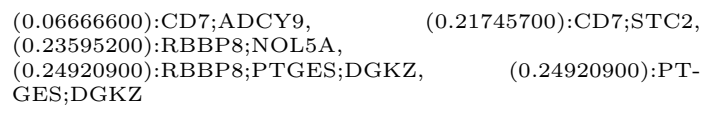 & 0.067 & & microtubule-based process \\
\hline RIPK3 & $\begin{array}{l}(0.06666600): \text { NIF3L1;GREB1, } \\
(0.21745700): F 10 ; \text { PTGES;STC2, } \\
\text { GES;PAFAH1B1, } \quad(0.21745700): \text { PT- } \\
(0.22061900): \text { PTGES;STC2 }\end{array}$ & 0.067 & & protein amino acid phosphorylation \\
\hline TNK1 & $\begin{array}{l}(0.06666600): \text { NIF3L1;GREB1, }(0.15079000): \text { NIF3L1;CTSD, } \\
(0.25091200): \text { RFPL2;IL6ST[CYT] } \\
\text { [JAK], } \\
(0.26666600): \text { NIF3L1;CTSD;KCNG1 }\end{array}$ & 0.067 & & autophosphorylation \\
\hline IL9R & $\begin{array}{l}(0.06666600): \text { HSPC111;NRIP1, } \quad(0.07692300): \text { F10;ALOX12B, } \\
(0.07692300): \text { PTGES;ALOX12B, } \\
(0.08412300): \text { NRIP1;PTGES, }(0.08412300): \text { PTGES;STC2 }\end{array}$ & 0.067 & $\begin{array}{l}{[\mathrm{CYT}]} \\
{[\mathrm{JAK}]}\end{array}$ & cell proliferation \\
\hline KEL & $\begin{array}{l}(0.06666600): \text { GREB1;CD7, } \quad(0.11587600): \text { SCN1B;GREB1, } \\
(0.15079000): \text { RBBP8;PTGES, } \\
(0.15079000): \text { RBBP8;PTGES;IGFBP4, } \\
(0.15079000): \text { NIF3L1;GREB1 }\end{array}$ & 0.067 & & N-linked glycosylation \\
\hline STK4 & $\begin{array}{l}(0.06666600): \text { CCNG2;LOR;CRABP2, } \\
(0.06666600): \text { LOR;CRABP2, } \\
(0.0666600): \text { CRABP2;FLJ22269, } \\
(0.11587600): \text { ELOVL2;LOR },(0.11587600): \text { CCNG } 2 ; \text { LOR }\end{array}$ & 0.067 & {$[\mathrm{MAPK}]$} & apoptosis \\
\hline $\operatorname{SSR} 2$ & 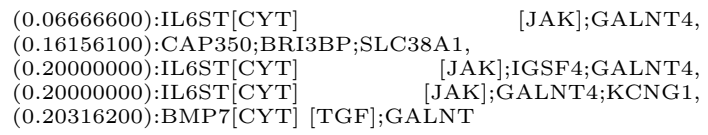 & 0.067 & & cotranslational protein-membrane targeting \\
\hline FIBP & 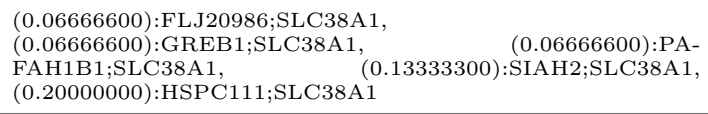 & 0.067 & & $\begin{array}{l}\text { fibroblast growth factor receptor signaling } \\
\text { pathway }\end{array}$ \\
\hline HMGCS1 & $\begin{array}{l}\text { (0.06666600): JAK1[JAK];AMD1, } \\
(0.2000000): \text { JAK1[JAK];AMD1;ELOVL2, } \\
(0.21062600): \text { AMD1;ALOX12B, } \\
(0.21745700): \text { GREB1;IL6ST[CYT] } \\
(0.23491400): \text { F10;FLJ20986 }\end{array}$ & 0.067 & & acetyl-CoA metabolism \\
\hline GPR64 & $\begin{array}{l}(0.06666600): \text { CENTG1; SIAH2, } \\
(0.06666600) \text { :CENTG1;CRABP2, } \\
(0.13333300): \text { CENTG1;RBBP }, \\
(0.16824700): \text { CENTG1;SERPINE1, } \\
(0.19558100): \text { ABCA3;LOR }\end{array}$ & 0.067 & & neuropeptide signaling pathway \\
\hline PCCA & $\begin{array}{l}(0.06666600): \text { JAK1[JAK];AMD1, } \\
(0.20000000): \text { JAK1[JAK];AMD1;ELOVL2, } \\
(0.21062600): \text { AMD } 1 ; \text { ALOX12B, } \\
(0.21745700): \text { HSPC111;OLFM1, } \\
(0.21745700): \text { HSPC } 111 ; \text { MPP } 3\end{array}$ & 0.067 & & fatty acid metabolism \\
\hline $\mathrm{DOC} 2 \mathrm{~B}$ & 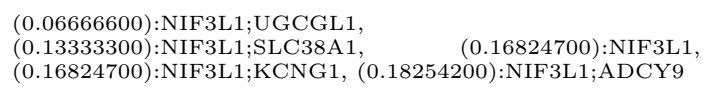 & 0.067 & & transport \\
\hline NEU3 & $\begin{array}{l}(0.06666600): \text { HSPC111;F10, } \\
(0.06666600): \text { HSPC111;F10;IGFBP } 4, \\
(0.06666600): \text { HSPC111;IGFBP } 4 \\
(0.13333300): \text { HSPC111;PTGES, } \\
(0.13333300): \text { HSPC } 111 ; \text { PTGES;IGFBP4 }\end{array}$ & 0.067 & & carbohydrate metabolism \\
\hline
\end{tabular}




\begin{tabular}{|c|c|c|c|c|}
\hline Gene & Preditores & Entropia & KEGG & Função Biológica \\
\hline WNT3 & 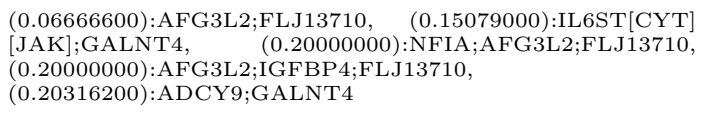 & 0.067 & {$[\mathrm{WNT}]$} & cell-cell signaling \\
\hline ALAD & $\begin{array}{l}(0.06666600): \text { NOL5A;AMD1, } \\
(0.13333300): \text { NOL5A;AMD1;FLJ22269, } \\
(0.15079000): \text { NIF3L1;ADCY9, } \\
(0.15079000): \text { ADCY9;GALNT },(0.17398900): \text { RFPL2;STC2 }\end{array}$ & 0.067 & & heme biosynthesis \\
\hline JRK & $\begin{array}{l}(0.06666600): \text { GREB1;CD7, } \quad(0.11587600): \text { SCN1B;GREB1, } \\
(0.13333300): \text { NFIA;FLJ20986;PAFAH1B1, } \\
(0.15079000): \text { NFIA;SCN1B, }(0.15079000): \text { SCN1B;OLFM1 }\end{array}$ & 0.067 & & biological process unknown \\
\hline SLC $34 \mathrm{~A} 1$ & 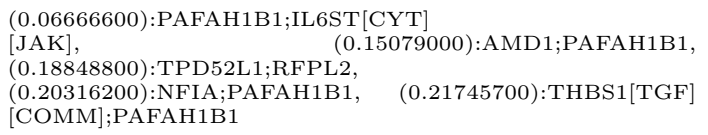 & 0.067 & & fluid secretion \\
\hline SPRR1B & $\begin{array}{lr}\text { (0.06666600):PTGES;CD7, } & (0.15079000): \text { NIF3L1;GREB1, } \\
\text { (0.18254200):CAP350;CD7, } & (0.18254200): \text { THBS1[TGF] } \\
\text { [COMM];CRABP2, } & (0.20000000): \text { BMP7[CYT] } \\
\text { [TGF];PTGES;CD7 } & \end{array}$ & 0.067 & & epidermis development \\
\hline ARF5 & 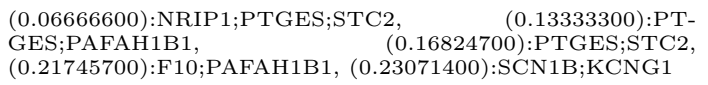 & 0.067 & & intracellular protein transport \\
\hline GJA7 & $\begin{array}{lr}(0.06666600): \text { RBBP } 8 ; \text { THBS1 }[\mathrm{TGF}] & {[\mathrm{COMM}],} \\
(0.06666600): \mathrm{LOR} ; \mathrm{THBS} 1[\mathrm{TGF}] & {[\mathrm{COMM}]} \\
(0.08412300): \mathrm{FLJ} 20986 ; \mathrm{EPHA} 4, & (0.11587600): \mathrm{CCNG} 2 ; \mathrm{LOR}, \\
(0.11587600): \text { THBS1 } & \end{array}$ & 0.067 & {$[\mathrm{COMM}]$} & cell communication \\
\hline $\mathrm{ABCE} 1$ & 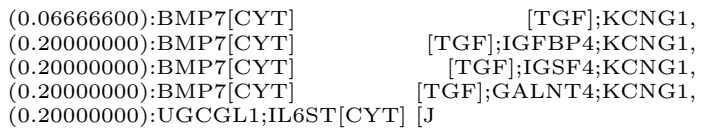 & 0.067 & & electron transport \\
\hline PEX11B & $\begin{array}{l}(0.06666600): \text { GREB1;SLC38A1, } \\
(0.20000000): J A K 1[J A K] ; \text { GREB1;SLC38A1, } \\
(0.20000000): \text { GREB1;PAFAH1B1;SLC38A1, } \\
(0.21745700): \text { NRIP1;GREB1, } \\
(0.23491400): \text { FLJ20986;SLC38A1 }\end{array}$ & 0.067 & & peroxisome division \\
\hline PROCR & $\begin{array}{l}(0.06666600): \text { JAK1[JAK]; GREB1, } \\
(0.06666600): J A K 1[\mathrm{JAK}] ; \text { CISH[JAK], } \\
(0.11587600): \mathrm{JAK} 1[\mathrm{JAK}],(0.13333300): \text { CENTG } 1 ; \mathrm{JAK} 1[\mathrm{JAK}] \\
(0.1333300): \text { NFIA;JAK1[JAK] }\end{array}$ & 0.067 & & blood coagulation \\
\hline BRMS1 & $\begin{array}{rr}(0.06666600): \text { BMP7[CYT] } & {[\text { TGF];HSPC111, }} \\
(0.06666600): \text { BMP7[CYT] } & {[\mathrm{TGF}] ; \mathrm{GALNT} 4} \\
(0.15079000): \text { BMP7[CYT] } & {[\mathrm{TGF}] ; \mathrm{F} 10,} \\
(0.15079000): \mathrm{BMP} 7[\mathrm{CYT}] & {[\mathrm{TGF}] ; \mathrm{F} 10 ; \mathrm{IGFBP} 4} \\
(0.15079000): \text { BMP7[CYT] }[\mathrm{TGF}] ; \mathrm{PTGES} & \end{array}$ & 0.067 & & cell cycle \\
\hline MFN1 & 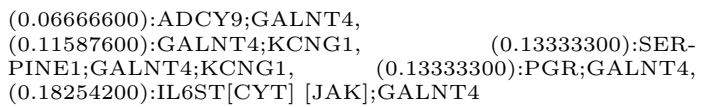 & 0.067 & & mitochondrial fusion \\
\hline AKR1B1 & $\begin{array}{l}(0.06666600): \text { IL6ST }[\mathrm{CYT}] \\
(0.13333300): \text { AMD1;IL6ST[CYT] } \\
(0.14285700): \text { TPD52L1;IL6ST[CYT] } \\
(0.18254200): \text { IL6ST[CYT] } \\
(0.20000000): \text { UGCGL1;IL6ST }\end{array}$ & 0.067 & & carbohydrate metabolism \\
\hline DOC1 & 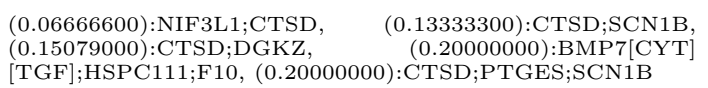 & 0.067 & & biological process unknown \\
\hline
\end{tabular}




\begin{tabular}{|c|c|c|c|c|}
\hline Gene & Preditores & Entropia & KEGG & Função Biológica \\
\hline G6PC & 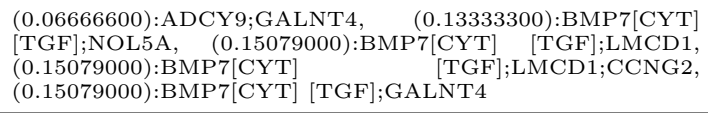 & 0.067 & & glucose metabolism \\
\hline NBL1 & $\begin{array}{l}(0.06666600): \text { CTSD;DGKZ, } \\
(0.2000000): R B B P 8 ; C T S D ; D G K Z, \\
(0.23298900): \text { TPD52L1;THBS1[TGF] [COMM];FLJ22269, } \\
(0.23491400): \text { NIF3L1;GREB1, }(0.23491400): \text { SCN1B;GALNT4 }\end{array}$ & 0.067 & & cell cycle \\
\hline ETFB & $\begin{array}{l}(0.06666600): \text { F10;FLJ20986, } \\
(0.13333300): \text { F10;FLJ20986;IGFBP4, } \\
(0.19558100): \text { CAP350;BRI3BP;SLC38A1, } \\
(0.20000000): \text { F10;FLJ20986;SLC38A1 } \\
(0.21745700): \text { F10;PAFAH1B1 }\end{array}$ & 0.067 & & electron transport \\
\hline CDKN1B & $\begin{array}{l}(0.06666600): \text { RBBP8;LMCD1, } \\
(0.0666660): \text { RBBP8;LMCD1;IGFBP4, } \\
(0.06666600): \text { RBBP8;THBS1[TGF] } \\
(0.06666600): \text { RBBP8;EPHA4, }(0.06666600): \text { LMCD1;IGFBP4 }\end{array}$ & 0.067 & {$[\mathrm{CC}]$} & cell cycle arrest \\
\hline RPA2 & $\begin{array}{l}(0.06666600): \text { NOL5A;CTSD }, \quad(0.15384600): \text { CTSD;RFPL2, } \\
\begin{array}{l}(0.16156100): \text { NOL5A;TPD52L1, } \\
(0.20000000): \text { NOL5A;CTSD;LMCD1 }\end{array}\end{array}$ & 0.067 & & DNA-dependent DNA replication \\
\hline MAD2L2 & $\begin{array}{l}(0.06666600): \text { UGCGL1;PTGES, } \\
(0.15079000): \text { NRIP1;PTGES;STC2, } \\
(0.15079000): \text { SCN1B;GALNT4, } \quad(0.16824700): \text { ADCY9;MPP3, } \\
(0.17398900): \text { NRIP1;ALOX12B }\end{array}$ & 0.067 & {$[\mathrm{CC}]$} & cell cycle \\
\hline BLM & $\begin{array}{l}\text { (0.06666600): UGCGL1;PTGES, } \\
(0.0666600): \text { SCN1B;FLJ22269, } \\
(0.08412300): \text { GALNT4;KCNG1, } \\
(0.11587600): \text { UGCGL1;IL6ST[CYT] [JAK] }\end{array}$ & 0.067 & & DNA recombination \\
\hline PALM & $\begin{array}{l}(0.06666600): \text { ADCY9;GALNT4, } \\
(0.13333300): \text { GREB } ; \text { GALNT4, } \\
(0.15079000): \text { RBBP8;IGFBP4;DGKZ, } \\
(0.15079000): \text { RBBP8;DGKZ;IGSF } 4 \\
(0.15079000): \text { FLJ20986;SLC38A1 }\end{array}$ & 0.067 & & cell motility \\
\hline TBX4 & $\begin{array}{l}\text { (0.06666600): ADCY9;FLJ22269, } \\
(0.13333300): H S P C 111 ; \text { AFG3L2;ADCY9, } \\
(0.13333300): \text { HSPC111;ADCY9, (0.13333300):RBBP8;AMD1, } \\
(0.13333300): \text { RBBP } ; \text { ADCY9 }\end{array}$ & 0.067 & & development \\
\hline $\mathrm{PDCD} 2$ & $\begin{array}{l}(0.06666600): \text { CD 7;ADCY9, } \\
(0.21745700): F 10 ; \mathrm{EPHA} 4 ; \mathrm{IGFBP} 4, \\
(0.15079000): \mathrm{F} 10 ; \mathrm{EPHA} 4, \\
(0.2856600): \mathrm{GREB} 1 ; \mathrm{CD} 7,\end{array}$ & 0.067 & & apoptosis \\
\hline IRX4 & $\begin{array}{l}(0.06666600): \text { CCNG2;LOR;CRABP2, } \\
(0.11587600): \text { CCNG2;LOR, } \\
\text { FAH1B1;PGR, } \quad(0.13333300): \text { PA- } \\
(0.15079000): \text { LOR;THBS1[TGF] [COMM] }\end{array}$ & 0.067 & & heart development \\
\hline CHST7 & $\begin{array}{l}(0.06666600): \text { CRABP2;FLJ22269, } \\
(0.11587600): \text { ELOVL2;LOR, } \\
(0.15079000): \text { ELOVL2;CCNG2;LOR, } \\
(0.17398900): \text { AMD1;ALOX12B, } \\
(0.18254200): \text { AFG3L2;ELOVL } 2 ; \text { LOR }\end{array}$ & 0.067 & & $\mathrm{~N}$-acetylglucosamine metabolism \\
\hline PPIG & $\begin{array}{ll}\text { (0.06666600):CRABP2;FLJ13710, } & (0.07692300): S E R- \\
\text { (0.06666600):FLJ13710;HIG2, } & (0.07692300): F L J 13710 ; A L O X 12 B \\
\text { PINE1;ALOX12B, } & \end{array}$ & 0.067 & & RNA splicing \\
\hline
\end{tabular}




\begin{tabular}{|c|c|c|c|c|}
\hline Gene & Preditores & Entropia & KEGG & Função Biológica \\
\hline $\mathrm{PKP} 4$ & $\begin{array}{l}(0.06666600): \text { CAP350;CD7, } \quad(0.15079000): \text { SERPINE1;HIG2, } \\
(0.18254200): \text { PTGES;CD7, } \\
\text { [TGF];PTGES;CD7, }(0.20000000): R B B P 8 ; C T S D ; C A P 350\end{array}$ & 0.067 & & cell adhesion \\
\hline HSPE1 & $\begin{array}{l}(0.06666600): \text { NIF3L1;GREB1, } \\
(0.21745700): \text { F10;PTGES;STC2, } \\
(0.21745700): \text { F10;PAFAH1B1, } \quad(0.22061900): \text { PTGES;STC2, } \\
(0.23491400): \text { RBBP } 8 ; F 10 ; \text { IGFBP } 4\end{array}$ & 0.067 & & protein folding \\
\hline $\mathrm{CORO} 2 \mathrm{~B}$ & $\begin{array}{l}(0.06666600): \text { NFIA;PAFAH1B1, } \\
(0.06666600): \text { FLJ20986;SERPINE1, } \\
(0.06666600): \text { FLJ20986;SERPINE1;EPHA4, } \\
(0.06666600): \text { FLJ20986;SLC38A1, } \\
(0.06666600): \text { GREB1;SLC38A1 }\end{array}$ & 0.067 & & $\begin{array}{l}\text { actin cytoskeleton organization and biogene- } \\
\text { sis }\end{array}$ \\
\hline STK19 & $\begin{array}{l}(0.06666600): \mathrm{JAK} 1[\mathrm{JAK}] ; \mathrm{AMD} 1, \\
(0.20000000): \mathrm{JAK} 1[\mathrm{JAK}] ; \mathrm{AMD} 1 ; \mathrm{ELOVL} 2, \\
(0.21062600): \text { AMD } 1 ; \mathrm{ALOX} 12 \mathrm{~B}, \\
(0.21745700): \text { GREB } 1 ; \mathrm{IL} 6 \mathrm{ST}[\mathrm{CYT}] \\
(0.23491400): \mathrm{F} 10 ; \mathrm{FLJ} 20986\end{array}$ & 0.067 & & protein amino acid phosphorylation \\
\hline CORO1C & $\begin{array}{l}(0.06666600): \text { NIF3L1;CTSD }, \quad(0.18254200): \text { CTSD;OLFM1, } \\
(0.18254200): \text { PTGES;OLFM1, } \\
(0.20000000): \text { F10;PTGES;OLFM1, }(0.20316200): \text { CTSD;F10 }\end{array}$ & 0.067 & & phagocytosis \\
\hline $\mathrm{HPN}$ & $\begin{array}{l}(0.06666600): \text { ADCY9;GALNT4, } \\
(0.21745700): \text { PGR;GALNT4, } \quad(0.26666600): \text { NOL5A;AFG3L2, } \\
(0.26666600): \text { UGCGL1;ADCY9;GALN4 } \\
(0.26666600): \text { EPHA4;IL6ST[CYT] [JAK] }\end{array}$ & 0.067 & & proteolysis and peptidolysis \\
\hline SFRP5 & $\begin{array}{l}(0.06666600): \text { NOL5A;CTSD, }(0.16156100): \text { NOL5A;TPD52L1, } \\
(0.20000000): \text { NOL5A;CTSD;LMCD1, } \\
(0.20000000): \text { SCN1B;GREB1, } \\
(0.20000000): \text { SCN1B;GREB1;STC2 }\end{array}$ & 0.067 & {$[\mathrm{WNT}]$} & Wnt receptor signaling pathway \\
\hline MAT2A & $\begin{array}{l}(0.06666600): \text { LOR;THBS1[TGF] } \\
(0.13333300): \text { F } 10 ; \text { SIAH2 } \quad(0.13333300): \text { F } 10 ; \text { SIAH2;IGFBP } 4, \\
(0.20000000): \text { HSPC } 111 ; \text { NRIP1;IGSF } 4, \\
(0.20000000): \text { HSPC } 111 ; \text { F } 10 ; \text { SIAH2 }\end{array}$ & 0.067 & & one-carbon compound metabolism \\
\hline LTB & $\begin{array}{l}(0.06666600): \text { NIF3L1;UGCGL1, } \\
(0.11587600): \text { UGCGL } 1 ; \text { IL6ST[CYT] } \\
\text { [JAK], } \quad(0.21745700): \text { UGCGL1;SLC38A1, } \\
(0.21745700): \text { ADCY9;SLC38A1, } \\
(0.23076900): \text { UGCGL } 1 ; \text { ALOX12B }\end{array}$ & 0.067 & {$[\mathrm{CYT}]$} & cell-cell signaling \\
\hline GGPS1 & $\begin{array}{l}(0.06666600): \text { PAFAH1B1;GALNT } 4 \\
(0.15079000): \text { FLJ20986;SLC38A1, } \\
(0.15079000): \text { GREB1;SLC38A1, } \\
(0.20000000): \text { JAK1[JAK];PAFAH1B1;GALNT4, } \\
(0.20000000): \text { FLJ20986;PAFAH1B1;SLC38A1 }\end{array}$ & 0.067 & & isoprenoid biosynthesis \\
\hline PPYR1 & $\begin{array}{l}(0.06666600): \mathrm{JAK} 1[\mathrm{JAK}] ; \mathrm{AMD} 1, \\
(0.06666600): \mathrm{CTSD} ; \mathrm{AMD} 1, \quad(0.06666600): \mathrm{AMD} 1 ; \mathrm{CRABP} 2, \\
(0.07692300): \mathrm{AMD} 1 ; \mathrm{ALOX} 12 \mathrm{~B},(0.11587600): A M D 1\end{array}$ & 0.067 & & $\begin{array}{l}\text { G-protein coupled receptor protein signaling } \\
\text { pathway }\end{array}$ \\
\hline DCI & 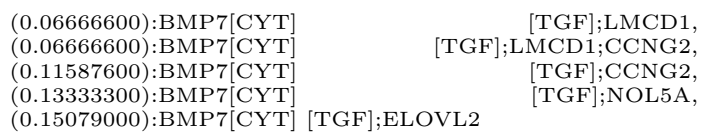 & 0.067 & & fatty acid metabolism \\
\hline EDNRA & $\begin{array}{l}(0.06666600): \text { CTSD;AMD1, } \quad(0.26666600): \text { CENTG1;SIAH2, } \\
(0.26666600): \text { JAK1[JAK];CTSD;AMD } 1, \\
(0.26666600): A M D 1 ; \text { PGR;KCNG1, } \\
(0.26666600): \text { AMD } 1 ; \text { CRABP2 }\end{array}$ & 0.067 & & $\begin{array}{l}\text { G-protein coupled receptor protein signaling } \\
\text { pathway }\end{array}$ \\
\hline SSR3 & $\begin{array}{l}(0.06666600): \text { SCN1B;PAFAH1B1, } \\
(0.20000000): \text { NIF3L1;SCN1B;KCNG1, } \\
(0.20000000): \text { SCN1B;PAFAH1B1;STC2, } \\
(0.24920900): \text { SIAH2;SCN1B },(0.24920900): \text { SCN1B;LOR }\end{array}$ & 0.067 & & cotranslational protein-membrane targeting \\
\hline
\end{tabular}




\begin{tabular}{|c|c|c|c|c|}
\hline Gene & Preditores & Entropia & KEGG & Função Biológica \\
\hline ADAM29 & $\begin{array}{l}(0.06666600) \text { :SCN1B;KCNG1, } \\
(0.07692300) \text { :NRIP1;ALOX12B, (0.08412300):NRIP1;PTGES, } \\
(0.13333300) \text { :CTSD;SCN1B, }(0.13333300): \text { PTGES;SCN1B }\end{array}$ & 0.067 & & proteolysis and peptidolysis \\
\hline CYP11B1 & $\begin{array}{l}(0.06666600): \text { NRIP1;LOR, } \\
(0.19558100): \text { LOR;BRI3BP, } \quad(0.20000000): L O R ; M P P 3 \\
(0.23298900): \text { LOR;PAFAH1B1;BRI3BP, } \\
(0.23491400): \text { F10;FLJ20986 }\end{array}$ & 0.067 & & C21-steroid hormone biosynthesis \\
\hline CRMP1 & $\begin{array}{l}(0.06666600): \mathrm{JAK} 1[\mathrm{JAK}] ; \mathrm{FLJ} 22269, \\
(0.06666600): \mathrm{SCN} 1 \mathrm{~B} ; \mathrm{FL} 222269, \\
(0.06666600): \mathrm{CRABP} ; \mathrm{FLJ} 22269 \\
(0.08412300): \text { ELOVL2;LOR, }(0.08412300): \mathrm{CCNG} 2 ; \mathrm{LOR}\end{array}$ & 0.067 & & neurogenesis \\
\hline SLC17A3 & $\begin{array}{lr}(0.06666600): \text { BMP7[CYT] } & {[\text { TGF];AMD1, }} \\
(0.17398900): A M D 1 ; A L O X 12 B, & (0.20000000): B M P 7[C Y T] \\
{[\text { TGGF];NRIP1;AMD1, }} & (0.20000000): \text { NRIP1;AMD1, } \\
(0.23076900): \text { FLJ20986;ALOX12B } & \end{array}$ & 0.067 & & ion transport \\
\hline $\mathrm{PTCH}$ & $\begin{array}{l}\text { (0.06666600):GREB1;FLJ22269, } \\
(0.1333300): \text { GREB1;IL6ST[CYT] } \\
{[\text { [JAK];FLJ22269, } \quad(0.15079000): \text { RBBP8;CAP350, }} \\
(0.15079000): \text { NOL5A;FLJ22269, } \\
(0.15079000): \text { NRIP1;PTGES;STC2 }\end{array}$ & 0.067 & & cell cycle \\
\hline $\mathrm{SLC} 12 \mathrm{~A} 4$ & $\begin{array}{l}(0.06666600): \text { SCN1B;OLFM1, } \\
\begin{array}{l}(0.13333300): \text { NIF3L1;SCN1B, } \\
(0.13333300): \text { SCN1B;IL6ST[CYT] [JAK] }\end{array}\end{array}$ & 0.067 & & amino acid transport \\
\hline PER2 & $\begin{array}{lr}(0.06666600): \text { NFIA;RBBP }, & (0.11587600) \text { :NFIA }, \\
(0.11587600) \text { :NFIA;FLJ20986, } & (0.13333300) \text { :NFIA;AMD1, } \\
(0.13333300) \text { :NFIA;AFG3L2 } & \end{array}$ & 0.067 & & circadian rhythm \\
\hline FLJ14249 & $\begin{array}{l}(0.06666600): \text { NIF3L1;GREB1, } \\
(0.26666600): \text { NIF3L1;GREB1;LMCD1, } \\
(0.2666660): \text { NIF3L1;GREB1;IL6ST[CYT] [TGF]:PTGES;CD7, } \\
(0.28412300): \text { BMP7[CYT] } \\
(0.29841800): \text { NRIP1;HIG2 }\end{array}$ & 0.067 & & intracellular signaling cascade \\
\hline KCNK7 & $\begin{array}{l}\text { (0.06666600):UGCGL1;PTGES, } \quad(0.06666600): \text { CTSD;AMD1, } \\
(0.0666660) \text { :AMD1;CRABP2, }(0.15079000): \text { PTGES;ADCY9, } \\
(0.15384600) \text { :AFG3L2;RFPL2;ADCY9 }\end{array}$ & 0.067 & & ion transport \\
\hline PLA2R1 & $\begin{array}{l}(0.06666600): \text { RBBP8;CAP350, }(0.11587600): \text { SIAH2;CAP350, } \\
(0.13333300): \text { RBBP8;CAP350;IGFBP4, } \\
(0.13333300): \text { RBBP8;CAP350;DGKZ, } \\
(0.13333300): \text { RBBP8;CAP350;IGSF 4 }\end{array}$ & 0.067 & & endocytosis \\
\hline TNP1 & $\begin{array}{l}(0.06666600): \text { SCN1B;CISH[JAK], }(0.18254200) \text { :NFIA;SCN1B, } \\
(0.20000000) \text { : NFIA;SCN1B;CISH[JAK] } \\
(0.22061900) \text { :NRIP1;PTGES, } \\
\text { GES;CCNG2;ALOX12B }\end{array}$ & 0.067 & & cell differentiation \\
\hline SIAT8E & $\begin{array}{l}(0.06666600): \text { ELOVL2;CRABP2, }(0.11587600): \text { ELOVL2;LOR, } \\
(0.13333300) \text { :CTBS;ELOVL2;CRABP2, } \\
(0.13333300): \text { ELOVL2;CCNG2;CRABP2, } \\
(0.13333300): \text { ELOVL2;LOR;CRABP2 }\end{array}$ & 0.067 & & carbohydrate metabolism \\
\hline C17orf31 & $\begin{array}{l}(0.06666600): \text { NIF3L1;GREB1, } \\
\begin{array}{l}(0.21745700): F 10 ; \text { PTGES;STC2, } \\
\text { GES;PAFAH1B1, } \\
(0.22061900): \text { PTGES;STC2 }\end{array}(0.21745700): \text { CAP350;PAFAH1B1, }\end{array}$ & 0.067 & & telomerase-dependent telomere maintenance \\
\hline $\mathrm{CHDH}$ & $\begin{array}{l}(0.06666600): \text { NIF3L1;GREB1, } \\
(0.14285700): \text { AFG3L2;LOR;BRI3BP, } \\
(0.15079000): \text { GREB1;IL6ST[CYT] } \\
(0.15079000): \text { IL6ST[CYT] } \\
(0.18254200): \text { NIF3L1;CTSD }\end{array}$ & 0.067 & & electron transport \\
\hline
\end{tabular}




\begin{tabular}{|c|c|c|c|c|}
\hline Gene & Preditores & Entropia & KEGG & Função Biológica \\
\hline RPS16 & $\begin{array}{l}(0.06666600): \text { CAP } 350 ; \text { CD } 7, \\
(0.20000000): \text { CTSD;CAP350;CD7, }(0.20000000): \text { F } 10 ; \text { SCN1B, } \\
(0.20000000): \text { FLJ20986;CD7, }(0.20000000): \text { SCN1B;CAP350 }\end{array}$ & 0.067 & & protein biosynthesis \\
\hline GYG2 & $\begin{array}{l}(0.06666600): \text { PAFAH1B1;KCNG1, } \\
(0.13333300): \text { HSPC111;KCNG1, } \\
(0.13333300): \text { NIF3L1;PAFAH1B1, } \\
(0.13333300): \text { NIF3L1;PAFAH1B1;KCNG1, } \\
(0.13333300): \text { CTSD;KCNG1 }\end{array}$ & 0.067 & & carbohydrate biosynthesis \\
\hline CHRAC1 & $\begin{array}{lr}(0.06666600): \text { PTGES;CD7, } & (0.18254200): \text { CAP350;CD7 } \\
(0.20000000): \text { BMP7[CYT] } & \text { [TGF];PTGES;CD7 } \\
(0.20000000): \text { PTGES;CD7;STC2 }, & (0.2000000): \text { PTGES;STC2 }\end{array}$ & 0.067 & & chromatin remodeling \\
\hline NFIA & $\begin{array}{l}(0.06666600): \text { CTBS;ELOVL2;CCNG2, } \\
(0.11587600): \text { CTBS;ELOVL2, } \\
(0.13333300): \text { CTBS;LMCD1;ELOVL2, } \\
(0.13649500): \text { CTBS;CCNG2, } \\
(0.15079000): \text { CTBS;CCNG2;CRABP2 }\end{array}$ & 0.067 & & DNA replication \\
\hline PKMYT1 & $\begin{array}{l}(0.06666600): \text { GREB1;FLJ22269, } \\
(0.13333300): \text { GREB1;IL6ST[CYT] } \\
(0.15079000): \text { NOL5A;AMD1, }(0.15079000): \text { NOL5A;FLJ22269, } \\
(0.15079000): \text { ADCY9;FLJ22269 }\end{array}$ & 0.067 & {$[\mathrm{CC}]$} & cell cycle \\
\hline TNFAIP 1 & $\begin{array}{l}(0.06666600): \text { NOL5A;NRIP1, } \quad(0.14285700): \text { NOL5A;BRI3BP, } \\
(0.20000000): \text { NIF3L1;NOL5A, } \\
(0.20000000): \text { NIF3L1;NOL5A;ADCY9 } \\
(0.20316200): \text { NRIP } 1 ; \text { LOR }\end{array}$ & 0.067 & & potassium ion transport \\
\hline FLJ22222 & $\begin{array}{l}(0.06666600): \text { CTSD;DGKZ, } \\
(0.08412300): \text { RBBP8;NOL5A, } \quad(0.08412300): \text { RBBP8;IGFBP4, } \\
(0.08412300): \text { RBBP8;IGSF4 }\end{array}$ & 0.067 & & protein metabolism \\
\hline $\mathrm{MYCN}$ & 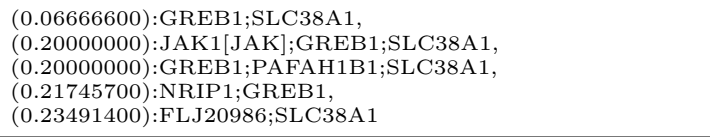 & 0.067 & & $\begin{array}{l}\text { regulation of transcription from RNA poly- } \\
\text { merase II promoter }\end{array}$ \\
\hline AATK & $\begin{array}{l}(0.06666600): \text { HSPC } 111 ; \text { NRIP } 1, \\
(0.20000000): \text { HSPC } 111 ; \text { NRIP } 1 ; \text { UGCGL } 1, \\
(0.20000000): \text { HSPC } 111 ; \text { NRIP } 1 ; \text { IGFBP } 4, \\
(0.20000000): \text { HSPC } 111 ; \text { NRIP } 1 ; \text { IGSF } 4 \\
(0.24920900): \text { HSPC } 111 ; \text { UGCGL } 1\end{array}$ & 0.067 & & protein amino acid phosphorylation \\
\hline TAF6 & $\begin{array}{l}(0.06666600): \text { JAK1[JAK];CTSD;SERPINE1, } \\
(0.13333300): \text { JAK1[JAK];CTSD;CAP350, } \\
(0.13333300): \text { CTSD;CAP350;SERPINE1, } \\
(0.19558100): \text { F10;BRI3BP, } \quad(0.21428500): \text { THBS1[TGF] } \\
\text { [COMM];BRI3BP }\end{array}$ & 0.067 & & regulation of transcription factor activity \\
\hline COL17A1 & $\begin{array}{l}(0.06666600): \text { SCN1B;CISH[JAK], } \\
(0.15079000): \text { NRIP } 1 ; \text { PTGES;STC } 2, \\
(0.18254200): \text { UGCGL1;PTGES, } \\
(0.20000000): \text { NFIA;SCN1B;CISH[JAK], } \\
(0.20000000): \text { NRIP } 1 ; \text { PTGES }\end{array}$ & 0.067 & {$[\mathrm{COMM}]$} & cell-matrix adhesion \\
\hline SNRPF & $\begin{array}{l}(0.06666600): \text { UGCGL } 1 ; \text { PTGES, }(0.22061900): \text { NRIP } 1 ; \text { PTGES, } \\
(0.23076900): \text { CTBS;RFPL2;ELOVL } 2, \\
(0.23491400): \text { NRIP } 1 ; \text { PTGES;STC } 2 \\
(0.26666600): \text { NRIP } 1 ; \text { UGCGL } 1 ; \text { PTGES }\end{array}$ & 0.067 & & nuclear mRNA splicing, via spliceosome \\
\hline LSAMP & $\begin{array}{lr}(0.06666600): \text { BMP7[CYT] } & {[\text { TGF];HSPC111, }} \\
(0.06666600): \text { BMP7[CYT] } & \text { [TGF];GALNT4, } \\
(0.11587600): H S P C 111, & (0.11587600): \text { GALNT4;KCNG1, } \\
(0.13333300): H S P C 111 ; \mathrm{JAK} 1[\mathrm{JAK}] & \end{array}$ & 0.067 & & cell adhesion \\
\hline EEF1A2 & $\begin{array}{l}(0.06666600): \text { NIF3L1; GREB1, } \quad(0.11587600): \text { SCN1B;GREB1, } \\
(0.15079000): \text { GREB1;CD7, } \quad(0.18254200): \text { NIF3L1;ADCY9, } \\
(0.21062600): \text { FLJ13710;ALOX12B }\end{array}$ & 0.067 & & protein biosynthesis \\
\hline
\end{tabular}




\begin{tabular}{|c|c|c|c|c|}
\hline Gene & Preditores & Entropia & KEGG & Função Biológica \\
\hline COL4A6 & 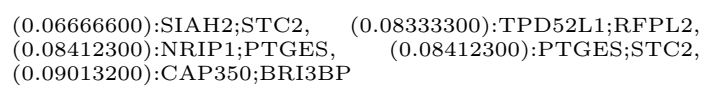 & 0.067 & {$[\mathrm{COMM}]$} & cell adhesion \\
\hline JAK2 & $\begin{array}{l}(0.06666600): \text { FLJ20986;:SERPINE1, } \\
(0.06666000): \text { FLJ2098; SERPINE1;EPHA4, } \\
(0.06666600): \text { SERPINE1;EPHA } 4 \\
(0.15079000): \text { ADCY9;GALNT4, } \\
(0.20000000): \text { FLJ20986;SERPINE1;PAFAH1B1 }\end{array}$ & 0.067 & {$[\mathrm{JAK}]$} & JAK-STAT cascade \\
\hline $\mathrm{ADCY} 8$ & $\begin{array}{lr}(0.06666600): \text { BMP7[CYT] } & {[\text { TGF];GALNT4, }} \\
(0.11587600): \text { GALNT4;KCNG1, } & (0.13333300): \text { PT- } \\
\text { GES;GALNT4, } & (0.15079000): \text { HSPC111;IGSF } 4 \\
(0.15079000): S C N 1 B ; G A L N T 4 & \end{array}$ & 0.067 & & cAMP biosynthesis \\
\hline MMP26 & 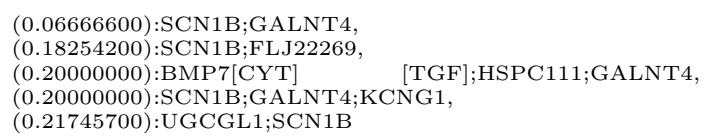 & 0.067 & & collagen catabolism \\
\hline RPS6KA5 & 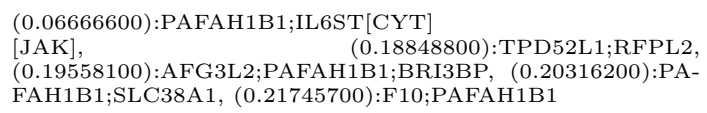 & 0.067 & {$[\mathrm{MAPK}]$} & $\begin{array}{l}\text { DNA damage induced protein phosphoryla- } \\
\text { tion }\end{array}$ \\
\hline UCHL1 & $\begin{array}{l}(0.06666600): \text { GREB1;CD7, } \quad(0.11587600): \text { SCN1B;GREB1, } \\
(0.15079000): \text { RBBP8;PTGES, } \\
(0.15079000): \text { RBBP8;PTGES;IGFBP4, } \\
(0.15079000): \text { NIF3L1;GREB } 1\end{array}$ & 0.067 & & protein deubiquitination \\
\hline ERBB2IP & $\begin{array}{lr}(0.06666600): \text { THBS1 }[\mathrm{TGF}] & {[\mathrm{COMM}] ; \mathrm{CRABP} 2,} \\
(\text { (CO14285700):TPD52L1;THBS1[TGF] } & \\
\text { [COMM];FLJ22269, } & (0.15079000): \mathrm{AMD} 1 ; \mathrm{CRABP} 2, \\
(0.20316200): \mathrm{CTSD} ; \mathrm{THBS} 1[\mathrm{TGF}] & \text { [COMM], } \\
(0.21745700): F 10 ; \mathrm{CRABP} 2 & \end{array}$ & 0.067 & & basal protein localization \\
\hline RARRES2 & $\begin{array}{l}(0.06666600): \text { NOL5A;CTSD }, \quad(0.11587600): \text { SCN1B;GREB1, } \\
(0.15079000): \text { GREB1;CD7, } \quad(0.16156100): \text { NOL5A;TPD52L1, } \\
(0.20000000): \text { NOL5A;CTSD;LMCD1 }\end{array}$ & 0.067 & & retinoid metabolism \\
\hline PTGFR & $\begin{array}{l}\text { (0.06666600):SCN1B;GALNT4, } \\
(0.1158760): \text { GALNT4;KCNG1, } \\
(0.13333300): \text { HSPC111;OLFM1, } \\
\text { (0.13333300):HSPC111;MPP3, } \quad(0.15079000): \text { BMP7[CYT] } \\
{[\text { TGF];GALNT4 }}\end{array}$ & 0.067 & & $\begin{array}{l}\text { G-protein coupled receptor protein signaling } \\
\text { pathway }\end{array}$ \\
\hline HAO1 & 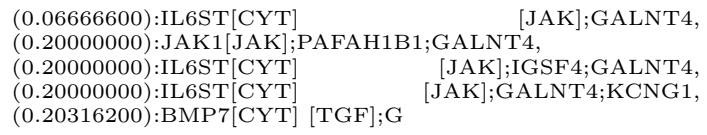 & 0.067 & & electron transport \\
\hline RGS3 & $\begin{array}{l}(0.06666600): \text { SCN1B; KCNG1, } \\
(0.20000000): \text { NIF3L; } \text { SCN1B;KCNG1 } \\
(0.20000000): \text { SCN1B;GREB1, } \\
(0.20000000): \text { SCN1B;GALNT4;KCNG1, } \\
(0.23491400): \text { SCN1B;GALNT4 }\end{array}$ & 0.067 & & inactivation of MAPK \\
\hline PLA2G6 & 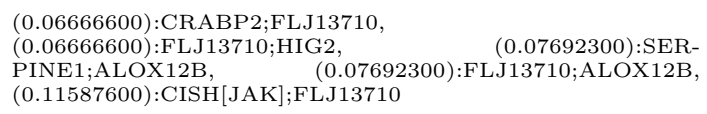 & 0.067 & {$[\mathrm{MAPK}]$} & lipid catabolism \\
\hline MYST1 & $\begin{array}{l}(0.06666600): \text { NRIP1;PTGES;IGFBP4, } \\
(0.0666600): \text { NRIP1;IGFBP4, } \quad(0.11587600) \text { :NRIP1;PTGES, } \\
(0.13333300): \text { NRIP1;F10, }(0.13333300): \text { NRIP1;F10;IGFBP4 }\end{array}$ & 0.067 & & chromatin assembly or disassembly \\
\hline $\mathrm{BRCA} 2$ & $\begin{array}{l}(0.06666600): \text { JAK1[JAK];GREB1, } \\
(0.13333300): \text { JAK1]JAK];GREB1;PAFAH1B1, } \\
(0.15079000): \text { JAK1[JAK];AMD1, } \\
(0.18254200): \text { JAK1[JAK];PAFAH1B1, } \\
(0.20000000): \text { NFIA;JAK1[JAK];PAFAH1B1 }\end{array}$ & 0.067 & & DNA repair \\
\hline
\end{tabular}




\begin{tabular}{|c|c|c|c|c|}
\hline Gene & Preditores & Entropia & KEGG & Função Biológica \\
\hline NEUROD1 & $\begin{array}{l}(0.06666600): \mathrm{BMP} 7[\mathrm{CYT}] \\
(0.06666600): \mathrm{BMP} 7[\mathrm{CYT}] \\
(0.06666600): \text { CTBS;LMCD1, } \\
(0.06666600): \text { CTBS;LMCD1;CCNG2, } \\
(0.06666600): \text { AFG3L2;LMCD1;CCNG2 }\end{array}$ & 0.067 & & cell differentiation \\
\hline AK5 & $\begin{array}{l}(0.07142800): \text { AFG3L2;PAFAH1B1;BRI3BP, }(0.07142800): \text { PA- } \\
\text { FAH1B1;BRI3BP, }(0.14285700): \text { CAP350;PAFAH1B1;BRI3BP, } \\
(0.14285700): \text { LOR;PAFAH1B1;BRI3BP, } \\
(0.18026500): \text { CAP350;BRI3BP }\end{array}$ & 0.071 & & ADP biosynthesis \\
\hline GLE1L & $\begin{array}{l}(0.07142800): \text { CAP350; BRI3BP; SLC38A1, } \\
(0.13333300): \text { CAP350;SLC38A1, } \quad(0.18254200): \text { CAP350;CD7, } \\
(0.23491400): \text { CENTG1;CRABP2, } \\
(0.26666600): \text { CENTG1;SIAH2 }\end{array}$ & 0.071 & & mRNA-nucleus export \\
\hline BMX & $\begin{array}{l}(0.07142800): \text { FLJ } 20986 ; \text { SERPINE } 1, \\
(0.07142800): \text { FLJ } 20986 ; \text { SERPINE1;EPHA4, } \\
(0.12415200): \text { FLJ20986;EPHA } 4 \\
(0.14285700): \text { EPHA4;PAFAH1B1, } \\
(0.16156100): \text { RBBP } 8 ; \text { EPHA4 }\end{array}$ & 0.071 & & intracellular signaling cascade \\
\hline PTPN12 & $\begin{array}{l}(0.07142800): \text { SIAH2;TPD52L1, } \\
(0.13333300): \text { FLJ20986;LMCD1, } \\
(0.14285700): \text { RBBP8;SIAH2;TPD52L1, } \\
(0.14285700): \text { RBBP8;TPD52L1;DGKZ, } \\
(0.14285700): \text { SIAH2;TPD52L1;IL6ST[CYT] [JAK] }\end{array}$ & 0.071 & & protein amino acid dephosphorylation \\
\hline STAR & $\begin{array}{l}(0.07142800): \text { FLJ } 20986 ; \text { SERPINE1, } \\
(0.09090900): \text { TPD52L1;RFPL2, } \quad(0.14285700): \text { SIAH2;STC2, } \\
(0.14285700): \text { FLJ20986;SERPINE1;EPHA4, } \\
(0.16156100): \text { RBBP } 8 ; \text { NOL5A }\end{array}$ & 0.071 & & C21-steroid hormone biosynthesis \\
\hline $\mathrm{SLC} 22 \mathrm{~A} 7$ & $\begin{array}{l}(0.07142800): \text { CAP350;BRI3BP; SLC38A1, } \\
(0.13333300): \text { CAP350;SLC38A1, } \quad(0.18254200): \text { CAP350;CD7, } \\
(0.23491400): \text { CENTG1;CRABP2, } \\
(0.26666600): \text { CENTG1;SIAH2 }\end{array}$ & 0.071 & & ion transport \\
\hline RALBP1 & $\begin{array}{l}(0.07142800): \text { CRABP } 2 ; \text { FLJ } 13710 \\
(0.07142800): \text { FLJ13710;GALNT } \\
(0.07142800): \text { FLJ13710;HIG2, } \\
(0.08333300): \text { FLJ13710;ALOX12B, } \\
(0.12415200): \text { CISH[JAK];FLJ } 13710\end{array}$ & 0.071 & & chemotaxis \\
\hline AVPR1B & $\begin{array}{l}\text { (0.07142800): CAP350;BRI3BP;SLC38A1, } \\
(0.07142800): \text { BRI3BP;SLC38A1, } \\
(0.12415200): \text { CAP350;BRI3BP, } \quad(0.12415200): \text { BRI3BP, } \\
(0.14285700): \text { GALNT } 4 \text {;BRI3BP }\end{array}$ & 0.071 & & $\begin{array}{l}\text { G-protein coupled receptor protein signaling } \\
\text { pathway }\end{array}$ \\
\hline LRP1 & $\begin{array}{l}(0.07142800): \text { TPD52L1;THBS1[TGF] } \\
(0.14285700): \text { NFIA;TPD52L1;THBS1[TGF] } \\
{[\text { COMM] }} \\
{[\text { COMM];FLJ22269, }} \\
(0.2000000): H S P C 111 ; \text { FLJ20986 }\end{array}$ & 0.071 & & cell proliferation \\
\hline GNRHR & 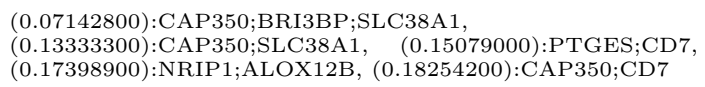 & 0.071 & & $\begin{array}{l}\text { G-protein coupled receptor protein signaling } \\
\text { pathway }\end{array}$ \\
\hline SEMG2 & $\begin{array}{l}(0.07142800): \text { PAFAH1B1;KCNG1, } \\
(0.14285700): \text { NIF3L1;PAFAH1B } 1, \\
(0.14285700): \text { NIF3L1;PAFAH1B1;KCNG1, } \\
(0.17398900): \text { AFG3L } 2 ; \text { PAFAH1B } 1 ; \mathrm{BRI} 3 \mathrm{BP}, \quad(0.23076900): \text { PT- } \\
\text { GES;CD } 7 \text { TPD52L } 1\end{array}$ & 0.071 & & sexual reproduction \\
\hline KERA & $\begin{array}{l}(0.07142800): \text { JAK1[JAK];FLJ22269, } \\
(0.07142800): \text { SCN1B;FLJ22269, } \\
(0.07692300): \text { ABCA3;FLJ22269, (0.09013200):ELOVL } 2 ; L O R, \\
(0.12415200): \text { FLJ22269 }\end{array}$ & 0.071 & & eye morphogenesis (sensu Mammalia) \\
\hline GPR57 & $\begin{array}{ll}(0.07142800): \text { ABCA } 3 \text { LOR }, & (0.07142800): \text { LOR;BRI3BP, } \\
(0.08412300): \text { ELOVL } 2 ; \text { LOR }, & (0.08412300): \text { CCNG } 2 ; L O R, \\
(0.13333300): \text { CENTG } 1 \text { LOR } & \end{array}$ & 0.071 & & $\begin{array}{l}\text { G-protein coupled receptor protein signaling } \\
\text { pathway }\end{array}$ \\
\hline
\end{tabular}




\begin{tabular}{|c|c|c|c|c|}
\hline Gene & Preditores & Entropia & KEGG & Função Biológica \\
\hline FOXD3 & $\begin{array}{l}(0.07142800): \text { CAP350;BRI3BP;SLC38A1, } \\
(0.13333300): \text { CAP350;SLC38A1, } \\
(0.18026500): \text { CAP } 350 ; \text { BRI3BP, } \\
(0.20000000): \text { SIAH2;AFG3L2;ADCY9, } \\
(0.20000000): \text { SIAH2;ADCY9 }\end{array}$ & 0.071 & & development \\
\hline PFKFB4 & $\begin{array}{l}(0.07142800): \text { CAP350;CD7, } \\
(0.07692300): \text { CAP350;BRI3BP;SLC38A1, } \\
(0.09013200): \text { BMP7[CYT] } \\
(0.09013200): \text { BMP7[CYT] [TGF];PTGES, } \\
(0.14285700): \text { BMP7[CYT] [TGF];PTGES;CD7 }\end{array}$ & 0.071 & & fructose 2,6 -bisphosphate metabolism \\
\hline CRSP6 & $\begin{array}{l}(0.07142800): \text { CTBS;NOL5A, } \\
\text { GES;SERPINE1, } \quad(0.16156100): \text { PT- } \\
\text { (0.21428500):CTBS;NOL5A;LMCD1, } \\
(0.21428500): \text { CTBS;NOL5A;CCNG2 }\end{array}$ & 0.071 & & androgen receptor signaling pathway \\
\hline VAMP4 & $\begin{array}{l}(0.07142800): \text { CAP350;BRI3BP;SLC38A1, } \\
\begin{array}{l}(0.07142800): B R I 3 B P ; S L C 38 A 1, \\
(0.13333300): \text { NIF3L1;SLC38A1, }(0.13333300): F 10 ; \text { SLC38A1 }\end{array}\end{array}$ & 0.071 & & protein complex assembly \\
\hline DYRK3 & 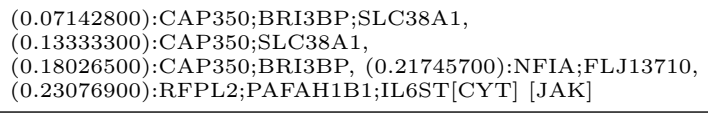 & 0.071 & & protein amino acid phosphorylation \\
\hline РAFAH2 & $\begin{array}{l}(0.07142800): B M P 7[C Y T] \\
(0.12415200): \text { CAP350;BRI3BP, } \\
(0.19558100): \text { CAP350;BRI3BP;SLC38A1, } \\
(0.2000000): \text { BMP7[CYT] [TGF];HSPC111;JAK1[JAK], } \\
(0.20316200): \text { BMP7[CYT] [TG]; JAK1[JAK] }\end{array}$ & 0.071 & & lipid catabolism \\
\hline $\mathrm{KCNC} 4$ & 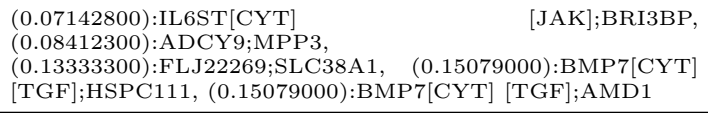 & 0.071 & & cation transport \\
\hline ARPC1B & $\begin{array}{l}(0.07142800): \text { ABCA3;LOR, } \quad(0.14285700): \text { NIF3L1;ABCA3, } \\
(0.14285700): \text { SIAH2;TPD52L1;FLJ22269, } \\
(0.15079000): \text { CENTG1;SIAH2, } \\
(0.15079000): \text { CENTG1;CRABP2 }\end{array}$ & 0.071 & {$[\mathrm{ACTIN}]$} & cell motility \\
\hline SEMA7A & $\begin{array}{l}(0.07142800): \text { CAP } 350 ; \mathrm{BRI} 3 B P ; \text { SLC } 38 A 1, \\
(0.13333300): \text { CAP } 350 ; \text { SLC } 38 A 1, \quad(0.18254200): \mathrm{CAP} 350 ; \mathrm{CD} 7, \\
(0.23491400): \text { CENTG1;CRABP2 } \\
(0.26666600): \text { CENTG1;SIAH2 }\end{array}$ & 0.071 & & cell differentiation \\
\hline TM4SF3 & 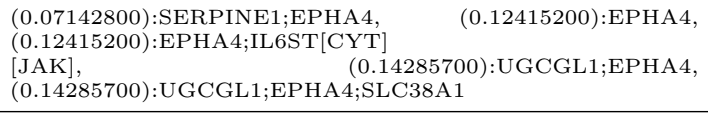 & 0.071 & & protein amino acid glycosylation \\
\hline PTPRS & $\begin{array}{l}\text { (0.07142800):AFG3L2;PAFAH1B1;BRI3BP, } \\
(0.13333300) \text { :AFG3L2;PAFAH1B1, } \\
(0.20000000) \text { :AFG3L2;:LMCD1;PAFAH1B1, } \\
(0.2000000) \text { :AFG3L2;CCNG2;PAFAH1B1, } \\
\text { FAH1B1;BRI3BP;KCNG1 }\end{array}$ & 0.071 & & cell adhesion \\
\hline KLHL1 & $\begin{array}{l}(0.07142800): \text { RBBP8; IGFBP4, } \quad(0.12415200): \text { :F10;IGFBP4, } \\
(0.12415200): \text { PTGES;IGFBP4, } \\
(0.14285700): \text { CTBS;PTGES;IGFBP4 }\end{array}$ & 0.071 & & $\begin{array}{l}\text { actin cytoskeleton organization and biogene- } \\
\text { sis }\end{array}$ \\
\hline TINAG & $\begin{array}{l}(0.07142800): \text { EPHA4;IL6ST [CYT] } \\
\text { [JAK], } \\
(0.1428500): \text { NFIA;EPHA4;IL6ST[CYT] } \\
(0.14285700): \text { NIF3L1;EPHA4, }(0.14285700): \text { NIF3L1;OLFM1 }\end{array}$ & 0.071 & & Malpighian tubule morphogenesis \\
\hline GPR58 & 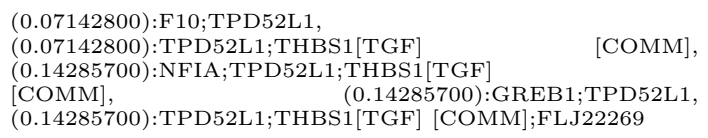 & 0.071 & & $\begin{array}{l}\text { G-protein coupled receptor protein signaling } \\
\text { pathway }\end{array}$ \\
\hline
\end{tabular}




\begin{tabular}{|c|c|c|c|c|}
\hline Gene & Preditores & Entropia & KEGG & Função Biológica \\
\hline VPREB1 & 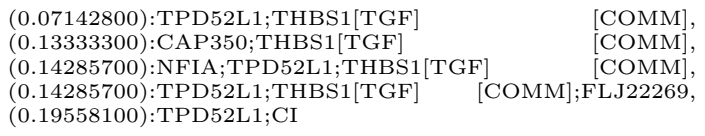 & 0.071 & & immune response \\
\hline PAPOLA & 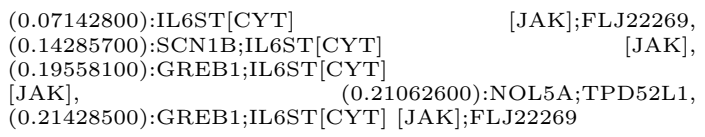 & 0.071 & & mRNA polyadenylylation \\
\hline EGR1 & $\begin{array}{l}(0.07142800): \text { AFG3L2;PAFAH1B1;BRI3BP, } \\
(0.13333300): \text { AFG3L2;PAFAH1B1, } \\
(0.15079000): \text { FLJ20986;SERPINE1;EPHA4, } \\
(0.15384600): \text { RFPL2;PAFAH1B1, } \\
(0.15384600): \text { RFPL2;PAFAH1B1;STC2 }\end{array}$ & 0.071 & & regulation of transcription, DNA-dependent \\
\hline RPS3 & $\begin{array}{ll}(0.07142800): \mathrm{LOR} ; \mathrm{THBS} 1[\mathrm{TGF}] & {[\mathrm{COMM}],} \\
(0.19558100): \text { CCNG } 2 ; \mathrm{LOR} ; \mathrm{CRABP} 2, & \\
(0.21428500): \mathrm{HSPC} 11 ; \text { F } 10 ; \mathrm{PTGES}, & \\
(0.21428500): \mathrm{LMCD} 1 ; \mathrm{LOR} ; \mathrm{THBS} 1[\mathrm{TGF}] & {[\mathrm{COMM}],} \\
(0.21878600): \text { CCNG } 2 ; \mathrm{LOR} & \end{array}$ & 0.071 & & protein biosynthesis \\
\hline $\mathrm{AKT} 2$ & $\begin{array}{lr}(0.07142800): \text { BMP7[CYT] } & \text { [TGF];BRI3BP, } \\
(0.15079000): \text { BMP7[CYT] } & \text { [TGF];GALNT4, } \\
(0.18254200): J A K 1[\mathrm{JAK}] ; \mathrm{CTSD} ; \mathrm{SERPINE} 1, & \\
(0.18254200): \text { IL6ST[CYT] } & \text { [JAK];GALNT4, } \\
(0.23410200): \text { IL6ST[CYT] [JAK];BRI3BP } & \end{array}$ & 0.071 & $\begin{array}{l}{[\mathrm{MAPK}]} \\
{[\mathrm{AP}]} \\
{[\mathrm{JAK}]} \\
{[\mathrm{TCELL}]} \\
{[\mathrm{TOLL}]}\end{array}$ & protein amino acid phosphorylation \\
\hline $\mathrm{C} 2$ & $\begin{array}{l}(0.07142800): \text { SIAH2;TPD52L1, } \\
(0.14285700): \text { RBBP8;SIAH2;TPD52L1, } \\
(0.14285700): \text { RBBP8;ABCA3, } \\
(0.14285700): \text { RBBP8;TPD52L1;DGKZ, } \\
(0.14285700): \text { SIAH2;TPD52L1;IL6ST[CYT] [JAK] }\end{array}$ & 0.071 & & complement activation, classical pathway \\
\hline SLC5A4 & $\begin{array}{l}(0.07142800): \text { AFG3L } 2 ; \text { ADCY9, } \\
(0.15384600): \text { AFG3L2;RFPL2;ADCY9, } \\
(0.16156100): \text { NIF3L1;ADCY9, (0.19558100):SCN1B;GREB1, } \\
(0.21428500): \text { HSPC111;AFG3L2;ADCY9 }\end{array}$ & 0.071 & & ion transport \\
\hline $\mathrm{SLC} 2 \mathrm{~A} 1$ & $\begin{array}{l}(0.07142800): \mathrm{JAK} 1[\mathrm{JAK}] ; \mathrm{AMD} 1, \quad(0.07142800): \mathrm{CTSD} ; \mathrm{AMD} 1, \\
(0.07142800): \mathrm{AMD} 1 ; \mathrm{PGR}, \quad(0.07142800): \mathrm{AMD} 1 ; \mathrm{CRABP} 2, \\
(0.12415200): \mathrm{AMD} 1\end{array}$ & 0.071 & & carbohydrate transport \\
\hline IL16 & $\begin{array}{l}(0.07142800): \text { BMP7[CYT] } \\
(0.15079000): \text { IGFBP4;CISH[JAK], } \\
(0.18254200): \text { JAK1 [JAK];FLJ22269, } \\
(0.21745700): \text { RBBP8;IGFBP4;CISH[JAK] } \\
(0.21745700): \text { F10;IGFBP4;CISH[JAK] }\end{array}$ & 0.071 & & chemotaxis \\
\hline VILL & 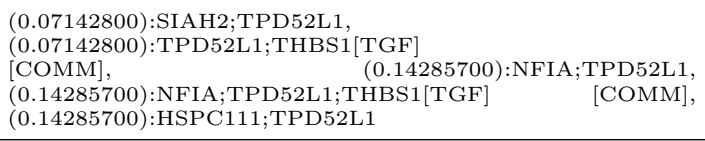 & 0.071 & & cytoskeleton organization and biogenesis \\
\hline IL1R1 & $\begin{array}{l}(0.07142800): S C N 1 B ; D G K Z, \quad(0.12415200): D G K Z, \\
(0.14285700): \text { CTBS;GREB1, }(0.14285700): J A K 1[J A K] ; D G K Z, \\
(0.14285700): \text { CTSD;DGKZ }\end{array}$ & 0.071 & $\begin{array}{l}{[\mathrm{MAPK}]} \\
{[\mathrm{AP}]} \\
{[\mathrm{CYT}]}\end{array}$ & $\begin{array}{l}\text { cell surface receptor linked signal transduc- } \\
\text { tion }\end{array}$ \\
\hline RAMP1 & $\begin{array}{l}(0.07142800): \text { PTGES;ADCY9, } \\
\text { GES;LMCD1;ADCY9, } \quad(0.19558100): \text { UGCGL1;PTGES, } \\
(0.21428500): \text { F10;EPHA4;IGFBP4, }(0.21428500): F 10 ; A D C Y 9\end{array}$ & 0.071 & & intracellular protein transport \\
\hline SLIT1 & $\begin{array}{l}(0.07142800): \text { NOL5A;TPD52L } 1, \quad(0.16156100): P T- \\
\text { GES;TPD52L1, } \\
(0.16267300): T P D 52 L 1,(0.18848800): T P D 52 L 1 ; \text { RFPL2 }\end{array}$ & 0.071 & & axon guidance \\
\hline F8 & $\begin{array}{lr}(0.07142800): \text { NFIA;SCN1B, } & (0.12415200): \text { NFIA, } \\
(0.12415200): \text { NFIA;FLJ20986, } & (0.12415200): \text { FLJ20986, } \\
(0.12415200): \text { FLJ20986;EPHA4 } & \end{array}$ & 0.071 & & acute-phase response \\
\hline
\end{tabular}




\begin{tabular}{|c|c|c|c|c|}
\hline Gene & Preditores & Entropia & KEGG & Função Biológica \\
\hline MRPS15 & $\begin{array}{l}(0.07142800): \text { PTGES;ADCY9, } \quad(0.16156100): B M P 7[C Y T] \\
{[\text { TGF];CTSD;F10, } \quad(0.16156100): B M P 7[C Y T] \quad[\text { TGF];F10, }} \\
(0.16156100): \text { ADCY9;IGFBP4 },(0.21428500): F 10 ; A D C Y 9\end{array}$ & 0.071 & & protein biosynthesis \\
\hline DAP13 & $\begin{array}{lr}(0.07142800): \text { IL6ST[CYT] } & \text { [JAK];BRI3BP, } \\
(0.16824700): \text { ADCY9;MPP3, } & \\
(0.24920900): \text { AFG3L2;IL6ST[CYT] } & \text { [JAK], } \\
(0.25091200): \text { RFPL2;IL6ST[CYT] } & \text { [JAK], } \\
0.26666600): \text { BMP7[CYT] [TGF];AMD1 } & \end{array}$ & 0.071 & & electron transport \\
\hline MAP3K4 & $\begin{array}{l}(0.07692300): \text { SERPINE1;ALOX12B, } \\
\text { GES;ALOX12B, } \quad(0.21062600): \text { PT- } \\
(0.23076900): \text { SERPINE1;FLJ13710;ALO1900):NRIP1;PTGES } \\
(0.23076900): \text { SERPINE1;ALOX12B;KCNG1 }\end{array}$ & 0.077 & {$[\mathrm{MAPK}]$} & JNK cascade \\
\hline B3GALT2 & $\begin{array}{l}\text { (0.07692300):FLJ13710;ALOX12B, } \\
(0.15079000): \text { CRABP2;FLJ13710, } \\
(0.15079000): \text { FLJ13710;HIG2, } \\
\text { PINE1;ALOX12B, }(0.18254200): \text { GREB1;CD7 }\end{array}$ & 0.077 & & protein amino acid glycosylation \\
\hline $\mathrm{PSMC} 3$ & $\begin{array}{l}(0.07692300): \text { SERPINE1;ALOX12B, } \\
(0.20000000): M P P 3 ; \mathrm{ILSST}[\mathrm{CYT}] \\
(0.20000000): \mathrm{MPP} 3 ; \mathrm{FLJ} 13710, \quad(0.21745700): \mathrm{MPP} 3 ; \mathrm{IGFB}] \\
(0.21745700): \mathrm{MPP} 3 ; \mathrm{IGFBP} 4 ; \mathrm{KCNG} 1\end{array}$ & 0.077 & & protein catabolism \\
\hline PDE3A & $\begin{array}{l}\text { (0.07692300):FLJ13710;ALOX12B, } \\
(0.15079000): \text { CRABP2;FLJ13710, } \\
(0.1507900): \text { FLJ13710;HIG2, } \\
\text { PINE1;ALOX12B, }(0.18254200): \text { GREB1;CD7 }\end{array}$ & 0.077 & & lipid metabolism \\
\hline SLC13A3 & $\begin{array}{l}(0.07692300): \text { SERPINE1;ALOX12B, } \\
(0.07692300): \text { FLJ13710;ALOX12B, } \\
(0.15079000): \text { AMD1;PAFAH1B1, } \\
(0.15079000): \text { ADCY9;FLJ22269, } \\
(0.15079000): \text { CRABP } 2 \text {; FLJ13710 }\end{array}$ & 0.077 & & ion transport \\
\hline C5R1 & $\begin{array}{l}\begin{array}{l}(0.07692300): A M D 1 ; A L O X 12 B, \\
\text { [COMM];KCNG1, }\end{array} \quad(0.15079000): \text { THBS1[TGF] } \\
(0.2000000): \text { NFIA;CTSD;FLJ20986, } \\
(0.21745700): \text { AMD1;PGR }\end{array}$ & 0.077 & & $\begin{array}{l}\text { G-protein coupled receptor protein signaling } \\
\text { pathway }\end{array}$ \\
\hline TXN2 & $\begin{array}{l}(0.07692300): \text { F10;ALOX12B, } \\
(0.15079000) \text { :NRIP1;PTGES;STC2, } \\
(0.2000000): \text { NRIP1;PTGES, } \\
(0.23076900) \text { :F10;ELOVL2;ALOX12B, } \\
(0.23076900): \text { F10;CCNG2;ALOX12B }\end{array}$ & 0.077 & & electron transport \\
\hline RAG2 & $\begin{array}{l}(0.07692300): \text { NRIP } 1 ; \text { ALOX12B, } \\
(0.15079000): \text { HSPC111;NRIP1, } \\
(0.15384600): \text { NRIP } 1 ; \text { JAK1[JAK];ALOX12B, } \\
(0.15384600): \text { :JAK1[JAK];ALOX12B, } \\
(0.16824700): \text { NRIP } 1 ; \text { PTGES }\end{array}$ & 0.077 & & DNA recombination \\
\hline ASB2 & $\begin{array}{l}(0.07692300): \text { SCN1B;GALNT4, } \\
\begin{array}{l}(0.13370300): G A L N 4 ; K C N G 1, \\
\text { FAH1B1;DGKZ;KCNG1, } \\
(0.17398900): \text { HSPC111;KCNG1 }\end{array} \quad(0.15384600): \text { DGKZ;KCNG1, }\end{array}$ & 0.077 & & intracellular signaling cascade \\
\hline CNTNAP2 & $\begin{array}{l}\text { (0.07692300):FLJ13710;ALOX12B, } \\
(0.15079000): \text { CRABP2;FLJ13710, } \\
(0.1507900): \text { FLJ13710;HIG2, } \\
\text { PINE1;ALOX12B, (0.18254200):GREB1;CD7 }\end{array}$ & 0.077 & & cell adhesion \\
\hline IL18R1 & $\begin{array}{l}(0.07692300): \text { NRIP1;ALOX12B, }(0.08412300): \text { NRIP1;PTGES, } \\
(0.15079000): \text { NRIP1;PTGES;IGFBP } 4, \\
(0.15079000): \text { NRIP1;PTGES;STC2, } \\
(0.15079000): \text { UGCGL1;PTGES }\end{array}$ & 0.077 & {$[\mathrm{CYT}]$} & immune response \\
\hline BLNK & $\begin{array}{l}(0.07692300): \text { SCN1B;DGKZ, } \\
\begin{array}{l}(0.15384600): S C N 1 B ; P A F A H 1 B 1 ; D G K Z, \\
(0.15384600): A D C Y 9 ; D G K Z, \quad(0.15384600): D G K Z ; S T C 2, \\
(0.15749500): D G K Z\end{array}\end{array}$ & 0.077 & & B cell differentiation \\
\hline
\end{tabular}




\begin{tabular}{|c|c|c|c|c|}
\hline Gene & Preditores & Entropia & KEGG & Função Biológica \\
\hline KITLG & $\begin{array}{l}(0.07692300): \text { NRIP } 1 ; \text { ALOX } 12 B \\
(0.15384600): \text { NRIP } 1 ; \text { JAK } 1[J A K] ; A L O X 12 B \\
(0.23076900): \text { NRIP } 1 ; \text { LMCD } 1 ; \text { ALOX } 12 B \\
(0.23076900): \text { NRIP } 1 ; \text { ELOVL } 2 ; \text { ALOX } 12 B \\
(0.23076900): \text { NRIP } 1 ; \text { CCNG } 2 ; \text { ALOX } 12 B\end{array}$ & 0.077 & {$[\mathrm{CYT}]$} & cell adhesion \\
\hline WRN & $\begin{array}{l}\text { (0.07692300):CAP350;TPD52L1, } \\
(0.13370300): \text { TPD52L1;THBS1[TGF] } \\
(0.14285700): \text { F10;EPHA4, } \\
\text { [COMM];EPHA4, } \\
\text { [COMM];EPHA4;FLJ22269 }\end{array}$ & 0.077 & & DNA metabolism \\
\hline NEO1 & $\begin{array}{l}(0.07692300): H S P C 111 ; \text { NRIP } 1, \quad(0.08333300): \text { THBS1[TGF] } \\
\text { [COMM];BRI3BP }, \quad(0.09706600): \text { NRIP1;PTGES } \\
(0.13370300): \text { HSPC111, } \\
\text { [JAK] }\end{array}$ & 0.077 & & cell adhesion \\
\hline KIAA1404 & 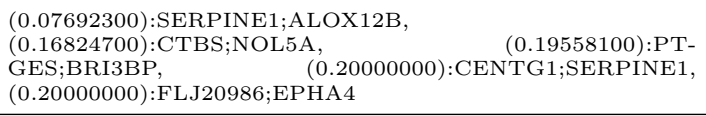 & 0.077 & & regulation of transcription, DNA-dependent \\
\hline ZNF16 & $\begin{array}{lr}(0.07692300): \text { BMP } 7 \text { CYT }] & {[\text { TGF }] \text {;ABCA3, }} \\
(0.07692300): \text { CTSD;ABCA3, } & \\
(0.07692300): \text { ABCA3;PAFAH1B1, } & (0.13370300): \text { ABCA3, } \\
(0.13370300): \text { ABCA3;SERPINE1 } & \end{array}$ & 0.077 & & regulation of transcription, DNA-dependent \\
\hline ELF5 & $\begin{array}{l}(0.07692300): \text { LMCD } 1 ; A L O X 12 B, \\
(0.15384600): \text { LMCD } 1 ; M P P 3 ; A L O X 12 B, \\
(0.15384600): \text { MPP3;ALOX12B, } \quad(0.18254200): \text { NIF3L1;CTSD, } \\
(0.21745700): \text { CENTG1;MPP3 }\end{array}$ & 0.077 & & cell proliferation \\
\hline UBD & $\begin{array}{l}(0.07692300): \text { RFPL2;ELOVL2, } \\
(0.15384600): \text { AFG3L2;RFPL2;ELOVL2, } \\
(0.15384600): \text { RFPL2;CCNG2, (0.18848800):TPD52L1;RFPL2 }\end{array}$ & 0.077 & & $\begin{array}{l}\text { antimicrobial humoral response (sensu Ver- } \\
\text { tebrata) }\end{array}$ \\
\hline ZNF277 & $\begin{array}{l}(0.07692300): R F P L 2 ; \mathrm{STC} 2, \quad(0.08333300): \text { TPD52L1;RFPL2, } \\
\begin{array}{l}(0.13370300): \mathrm{RFPL} 2, \\
(0.15384600): \mathrm{RBBP} ; \mathrm{RFPL} 2\end{array}\end{array}$ & 0.077 & & regulation of transcription, DNA-dependent \\
\hline NPEPL1 & 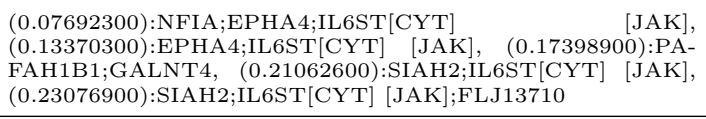 & 0.077 & & protein metabolism \\
\hline PITPNB & $\begin{array}{l}(0.07692300): A M D 1 ; A L O X 12 B, \\
(0.23076900): A M D 1 ; \text { ELOVL2;ALOX12B, } \\
(0.28754900): \text { CTBS;ELOVL2;ALOX12B, } \\
(0.28754900): \text { CTBS;ALOX12B, } \quad(0.30261900): B M P 7[C Y T] \\
{[\text { TGF];AMD1 }}\end{array}$ & 0.077 & & lipid metabolism \\
\hline DEFA4 & $\begin{array}{l}(0.07692300): \text { RFPL2;STC2, } \\
\begin{array}{l}(0.08412300): \text { RBBP } 8 \text { NOL5A }, \\
(0.13370300): \text { RFPL2 }\end{array}\end{array}$ & 0.077 & & defense response to bacteria \\
\hline GOSR1 & $\begin{array}{l}(0.07692300): \mathrm{F} 10 ; \mathrm{ALOX} 12 \mathrm{~B}, \quad(0.07692300): \mathrm{PT}- \\
\mathrm{GES} ; \mathrm{ALOX} 12 \mathrm{~B}, \quad(0.15384600): \mathrm{HSPC} 111 ; \mathrm{ALOX} 12 \mathrm{~B}, \\
(0.15384600): \mathrm{CD} 7 ; \mathrm{ALOX} 12 \mathrm{~B},(0.21062600): \mathrm{NRIP} 1 ; \mathrm{ALOX} 12 \mathrm{~B}\end{array}$ & 0.077 & & ER to Golgi transport \\
\hline IFNG & $\begin{array}{l}(0.07692300): \text { LMCD } 1 ; A L O X 12 B \\
(0.15079000): \text { CTSD;LMCD } 1, \\
(0.15079000): \text { LMCD } 1 ; \text { PAFAH } 1 B 1 \\
(0.15384600): \text { RFPL } 2 ; \text { LMCD } 1, \\
(0.15384600): \text { LMCD } 1 ; \text { MPP } 3 ; \text { ALOX } 12 B\end{array}$ & 0.077 & $\begin{array}{l}{[\mathrm{CYT}]} \\
{[\mathrm{JAK}]} \\
{[\mathrm{KILL}]} \\
{[\mathrm{TGF}]} \\
{[\mathrm{TCELL}]}\end{array}$ & cell motility \\
\hline NOV & 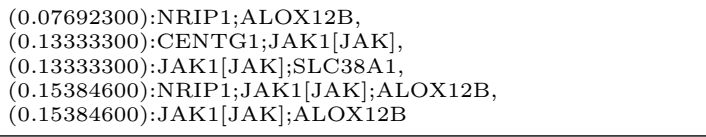 & 0.077 & & regulation of cell growth \\
\hline
\end{tabular}


113

\begin{tabular}{|c|c|c|c|c|}
\hline Gene & Preditores & Entropia & KEGG & Função Biológica \\
\hline ITPKA & $\begin{array}{l}(0.07692300): \text { SERPINE1;ALOX12B, } \\
(0.07692300): \text { FLJ13710;ALOX12B } \\
(0.15079000): \text { AMD1;PAFAH1B1, } \\
(0.15079000): \text { ADCY9;FLJ22269 } \\
(0.15079000): \text { CRABP2;FLJ13710 }\end{array}$ & 0.077 & & signal transduction \\
\hline WBP2 & $\begin{array}{l}(0.07692300): \text { AFG3L2;RFPL } 2, \\
(0.07692300) \text { AFG3L2;RFPL2;BRI3BP, } \\
(0.07692300): \text { RFPL2;BRI3BP, } \\
(0.15384600): \text { AFG3L2;RFPL2;ELOVL2, } \\
(0.15384600): \text { AFG3L2;RFPL2;ADCY9 }\end{array}$ & 0.077 & & biological process unknown \\
\hline CARD15 & $\begin{array}{l}(0.07692300): \text { F10;ALOX12B, } \\
(0.15079000): \text { :CENTG1;CRABP } 2 \\
(0.15384600): \text { CD } 7 \text {;ALOX12B, } \\
(0.20000000): \text { UGCGL1;IL6STCYT] } \\
(0.23076900): \text { :F10;ELOVL2;ALOX12B }\end{array}$ & 0.077 & & regulation of apoptosis \\
\hline NPY & $\begin{array}{l}(0.07692300): \text { FLJ13710;ALOX12B, } \\
(0.15079000): \text { CRABP2;FLJ13710, } \\
\text { (0.15079000):FLJ13710;HIG2, } \quad(0.17398900): \text { SER- } \\
\text { PINE1;ALOX12B, }(0.18254200): \text { GREB1;CD7 }\end{array}$ & 0.077 & & $\begin{array}{l}\text { G-protein signaling, coupled to cyclic nucle- } \\
\text { otide second messenger }\end{array}$ \\
\hline ANGPTL2 & $\begin{array}{l}\text { (0.07692300):AMD1;ALOX12B, } \quad(0.13333300): \text { AMD1;HIG2, } \\
\text { (0.15079000):JAK1[JAK];AMD1, } \\
\text { (0.15079000):AMD1;CRABP2 }\end{array}$ & 0.077 & & development \\
\hline $\mathrm{CHIC2}$ & $\begin{array}{l}(0.07692300): \text { NRIP1;ALOX12B, } \\
(0.13333300): \text { JAK1[JAK];PTGES, } \\
(0.13333300): \text { JAK1[JAK];KCNG1, } \\
(0.15384600): \text { NRIP1;JAK1[JAK];ALOX12B, } \\
(0.15384600): \text { JAK1[JAK];ALOX12B }\end{array}$ & 0.077 & & biological process unknown \\
\hline HOXD3 & 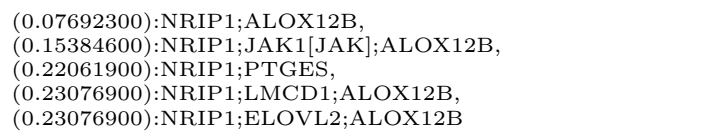 & 0.077 & & morphogenesis \\
\hline FUT4 & $\begin{array}{l}(0.07692300): \text { SERPINE1;ALOX12B, } \\
(0.12415200): \text { ABCA3;SERPINE1, } \\
\text { (0.13333300):CTBS;ELOVL2;CRABP2, }(0.13333300): \text { SER- } \\
\text { PINE1;STC2, (0.15079000):CTBS;CCNG2;CRABP2 }\end{array}$ & 0.077 & & L-fucose catabolism \\
\hline SAFB & $\begin{array}{l}(0.07692300): \text { NRIP1;ALOX12B, } \\
(0.15384600): \text { NRIP1;JAK1[JAK];ALOX12B, } \\
(0.20000000) \text { :NRIP1;PTGES, } \\
\text { GES;ALOX12B, (0.23076900):NRIP1;LMCD1;ALOX12B }\end{array}$ & 0.077 & & $\begin{array}{l}\text { establishment and/or maintenance of chro- } \\
\text { matin architecture }\end{array}$ \\
\hline SMARCA2 & $\begin{array}{l}(0.07692300): \text { AMD1;ALOX12B, } \\
(0.21745700) \text { :NRIP1;LLJ22269, } \\
(0.23076900) \text { :AMD1;ELOVL2;ALOX12B, } \\
(0.23298900): \text { CAP350;PAFAH1B1;BRI3BP, } \\
(0.23491400): \text { BMP7[CYT] [TGF];KCNG1 }\end{array}$ & 0.077 & & cell cycle \\
\hline DMAP1 & $\begin{array}{l}(0.07692300): \text { NRIP1;ALOX12B, } \\
(0.13333300) \text { :CENTG1;JAK1[JAK], } \\
(0.13333300): \text { JAK1[JAK];SLC38A1, } \\
(0.15384600): \text { NRIP1;JAK1[JAK];ALOX12B, } \\
(0.15384600): \text { JAK1[JAK];ALOX12B }\end{array}$ & 0.077 & & DNA methylation \\
\hline PASK & 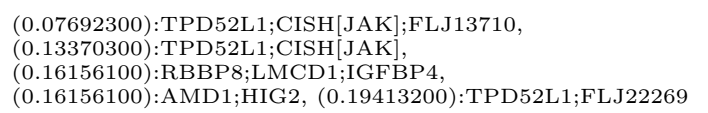 & 0.077 & & protein amino acid phosphorylation \\
\hline GCNT3 & $\begin{array}{l}(0.07692300): \text { FLJ13710;ALOX12B, } \\
(0.15079000): \text { CRABP2; FLJ13710, } \\
\text { (0.15079000):FLJ13710;HIG2, } \quad(0.17398900): \text { SER- } \\
\text { PINE1;ALOX12B, }(0.18254200) \text { :GREB1;CD7 }\end{array}$ & 0.077 & & O-linked glycosylation \\
\hline UBE2D2 & $\begin{array}{lr}(0.07692300): \mathrm{RBBP} 8 ; \mathrm{IL} 6 \mathrm{ST}[\mathrm{CYT}] & \text { [JAK], } \\
(0.0769230): \mathrm{RBBP} 8 ; \mathrm{ILSTT}[\mathrm{CYT}] & \text { [JAK];DGKZ, } \\
(0.07692300): \mathrm{IL6ST} \text { [CYT] } & \text { [JAK];DGKZ, } \\
(0.15384600): \mathrm{RBBP} 8 ; \mathrm{FL} J 20986 ; \mathrm{IL} 6 \mathrm{ST}[\mathrm{CYT}] & \text { [JAK], } \\
(0.15384600): \mathrm{RBBP} 8 \text { IL6ST[CYT] [JAK]; } & \end{array}$ & 0.077 & & ubiquitin cycle \\
\hline
\end{tabular}




\begin{tabular}{|c|c|c|c|c|}
\hline Gene & Preditores & Entropia & KEGG & Função Biológica \\
\hline SULT2A1 & $\begin{array}{l}\text { (0.07692300):FLJ13710;ALOX12B, } \\
\begin{array}{l}\text { (0.11587600):SCN1B;GREB1, } \\
(0.15079000): \text { CAP350;CD7, }(0.15079000): \text { :CRABP2;FLJ13710 }\end{array}\end{array}$ & 0.077 & & bile acid catabolism \\
\hline HOOK1 & $\begin{array}{l}\text { (0.07692300):SERPINE1;ALOX12B, } \\
\text { (0.12415200):ABCA3;SERPINE1, } \\
\text { PINE1;KCNG1, (0.20000000):CENTG1;SERPINE1;GALANT4, } \\
\text { (0.21428500):ABCA3;SERPINE1;KCNG1 }\end{array}$ & 0.077 & & cell differentiation \\
\hline DNAJB5 & $\begin{array}{l}\text { (0.07692300):AMD1;ALOX12B }, \quad(0.14285700): \text { AMD1;ABCA3, } \\
\text { [COMM];KCNG1 } \\
(0.15079000): \text { THBS1[TGF] }\end{array}$ & 0.077 & & protein folding \\
\hline FBXO21 & 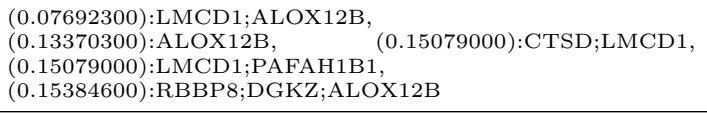 & 0.077 & & ubiquitin cycle \\
\hline COL8A1 & $\begin{array}{l}\text { (0.07692300): SERPINE1;ALOX12B, } \\
(0.21062600) \text { :FLJ13710;ALOX12B, } \\
(0.21428500) \text { :ABCA3;FLJ13710, } \\
\text { (0.21745700):STC2;FLJ13710, } \\
\text { PINE1;FLJ13710;ALOX12B }\end{array}$ & 0.077 & & cell adhesion \\
\hline IMPA2 & $\begin{array}{l}(0.07692300): \mathrm{F} 10 ; \mathrm{ALOX} 12 \mathrm{~B}, \quad(0.15384600): \mathrm{CD} 7 ; \mathrm{ALOX} 12 \mathrm{~B}, \\
(0.23076900): \mathrm{F} 10 ; \mathrm{ELOVL} 2 ; \mathrm{ALOX} 12 \mathrm{~B}, \\
(0.23076900): \mathrm{F} 10 ; \mathrm{CCNG} 2 ; \mathrm{ALOX} 12 \mathrm{~B}, \\
(0.23076900): \mathrm{CD} 7 \text {;ELOVL2;ALOX12B }\end{array}$ & 0.077 & & phosphate metabolism \\
\hline MST1R & 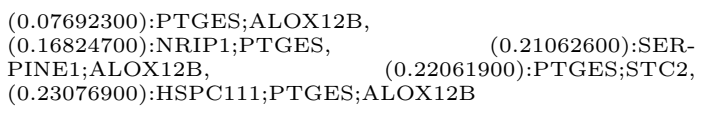 & 0.077 & & cell motility \\
\hline ADCYAP1R1 & $\begin{array}{l}(0.07692300): \text { FLJ13710;ALOX12B, } \\
(0.15079000): \text { NOL5A;AMD1, }(0.15079000): \text { NOL5A;FLJ22269, } \\
(0.15079000): \text { CRABP2;FLJ13710, } \\
(0.15079000): \text { FLJ13710;HIG2 }\end{array}$ & 0.077 & & $\begin{array}{l}\text { G-protein coupled receptor protein signaling } \\
\text { pathway }\end{array}$ \\
\hline NMI & $\begin{array}{l}(0.07692300): \text { SERPINE1;ALOX12B, } \\
(0.23076900) \text { :SERPINE1;FLJ13710;ALOX12B, } \\
(0.23076900) \text { :SERPINE1;ALOX12B;KCNG1, } \\
(0.23076900) \text { : ELOVL2;FLJ13710;ALOX12B, } \\
(0.23076900) \text { :CCNG2;FLJ13710;ALOX12B }\end{array}$ & 0.077 & & JAK-STAT cascade \\
\hline NRP2 & 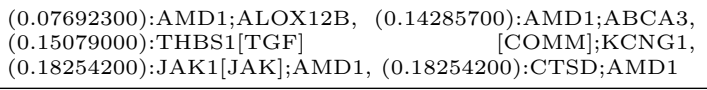 & 0.077 & & angiogenesis \\
\hline DLL3 & 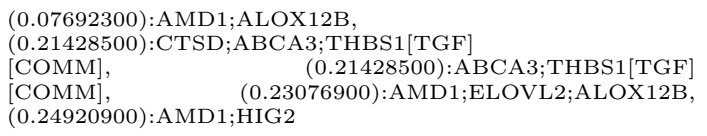 & 0.077 & & Notch signaling pathway \\
\hline GTF2H1 & $\begin{array}{l}\text { (0.07692300):AFG3L2;RFPL2, } \\
(0.07692300) \text { :AFG3L2;RFPL2;BRI3BP, } \\
\begin{array}{l}(0.07692300): \text { RFPL2;BRI3BP, } \\
(0.14285700): \text { TPD } 22 L 1 ; \text { THBS1[TGF] [COMM];FLJ22269 }\end{array}\end{array}$ & 0.077 & & DNA repair \\
\hline ESRRG & $\begin{array}{lr}(0.07692300): \text { BMP7[CYT] } & \text { [TGF];BRI3BP, } \\
(0.09013200): \text { BMP7[CYT] } & \text { [TGF];CCNG2, } \\
(0.09013200): \text { BMP7[CYT] } & \text { [TGF];KCNG1, } \\
(0.14285700): \text { BMP7[CYT] } & \text { [TGF];UGCGL1, } \\
(0.14624500): \text { BMP7[CYT] }[\mathrm{TGF}] & \end{array}$ & 0.077 & & development \\
\hline DPH2L1 & $\begin{array}{l}(0.07692300): \text { F10;ALOX12B, } \\
(0.16156100): \text { F1; TPD52L1, } \quad(0.20316200): \text { HSPC111;F10, } \\
(0.20316200): H S P C 111 ; \text { F10;IGFBP4, } \\
(0.21428500): F 10 ; A B C A 3\end{array}$ & 0.077 & & protein biosynthesis \\
\hline
\end{tabular}

Tabela C.1: Lista dos 235 genes melhores preditos pelos genes-sementes da Tabela 5.1 
A Figura C.1 mostra as tabelas de predições para os genes relacionados à função de adesão celular com os genes de seu melhor subconjunto de predição.

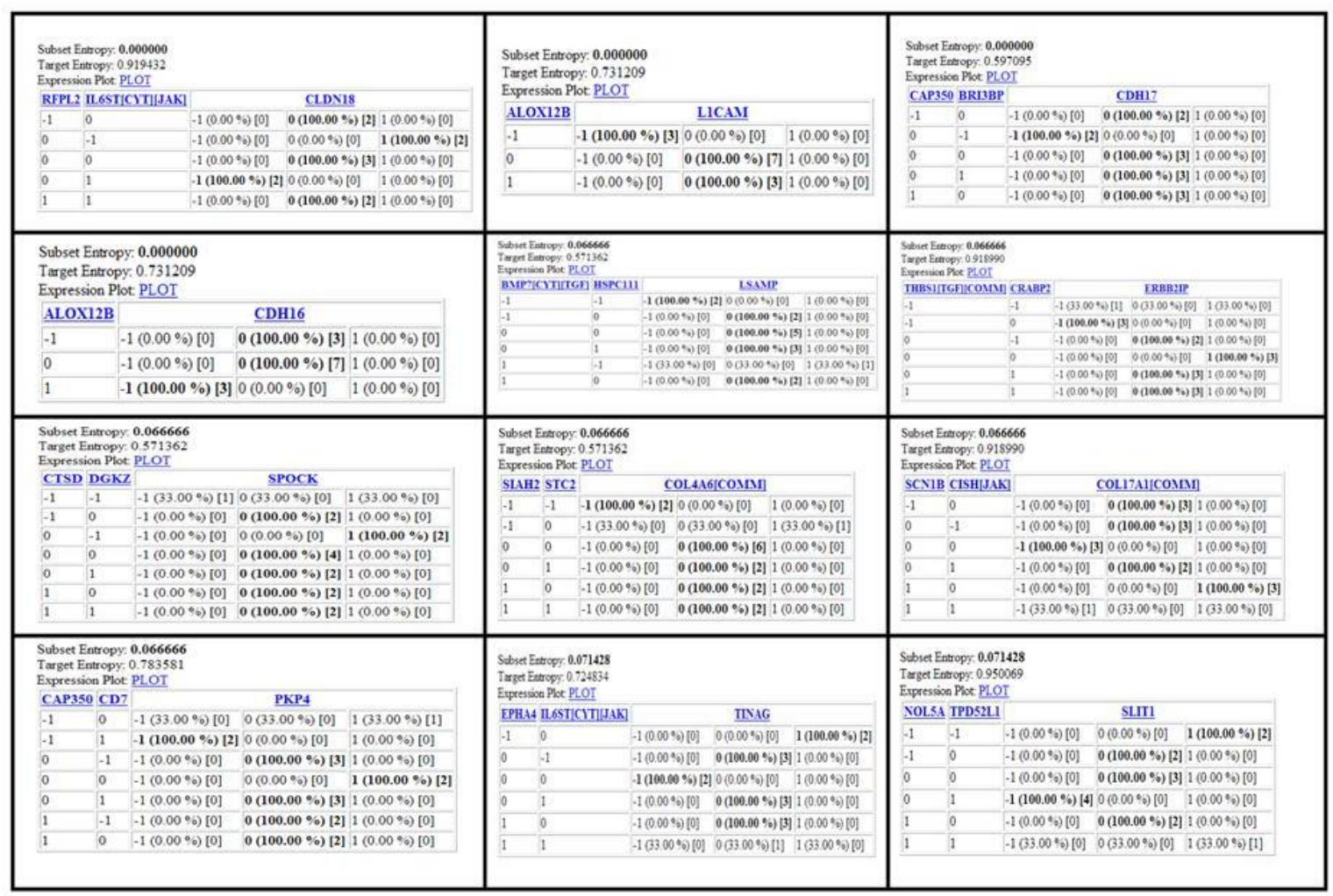

A Figura C.2 mostra os gráficos dos sinais dos genes relacionados à função de adesão celular e os genes do seu melhor subconjuntos de predição. 


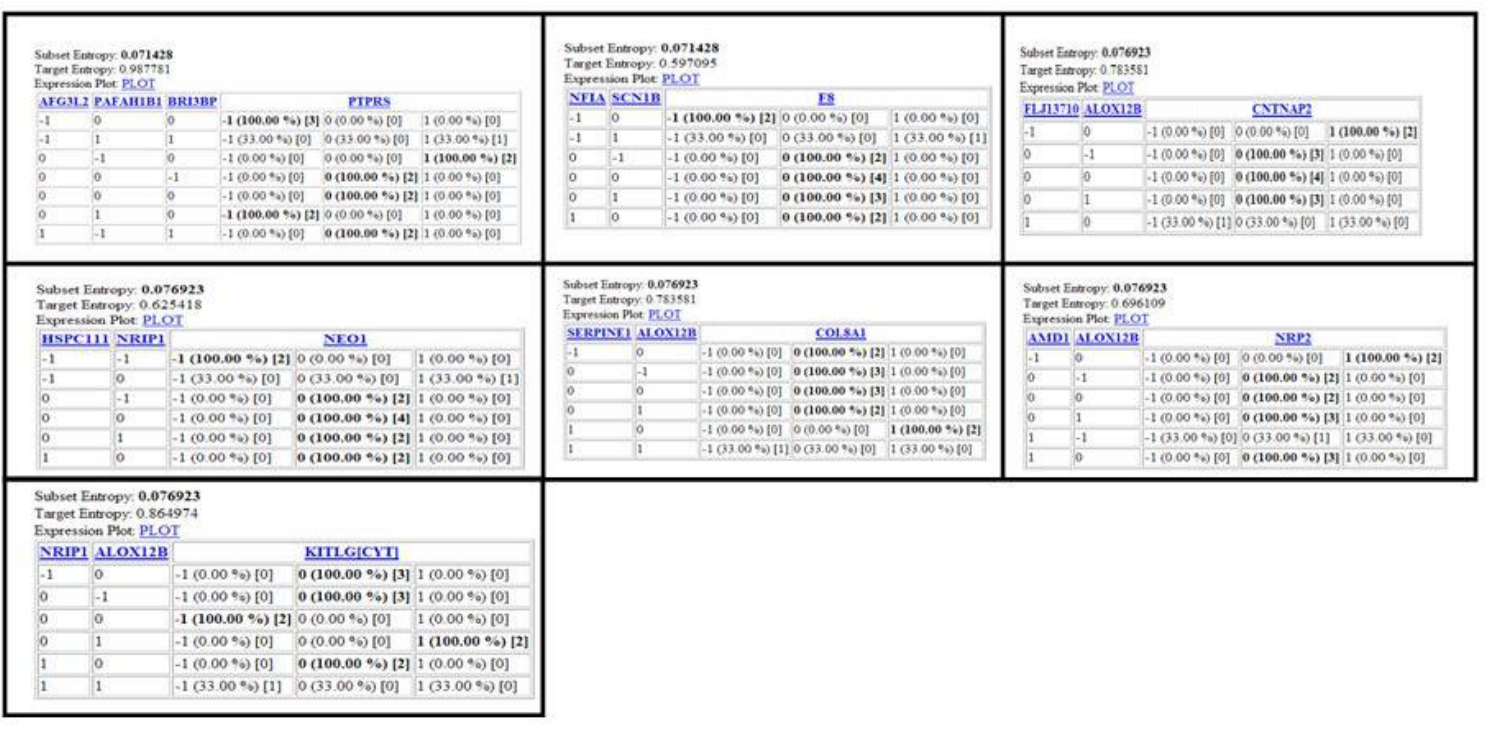

Figura C.1: Tabelas de predições dos genes relacionados à adesão celular

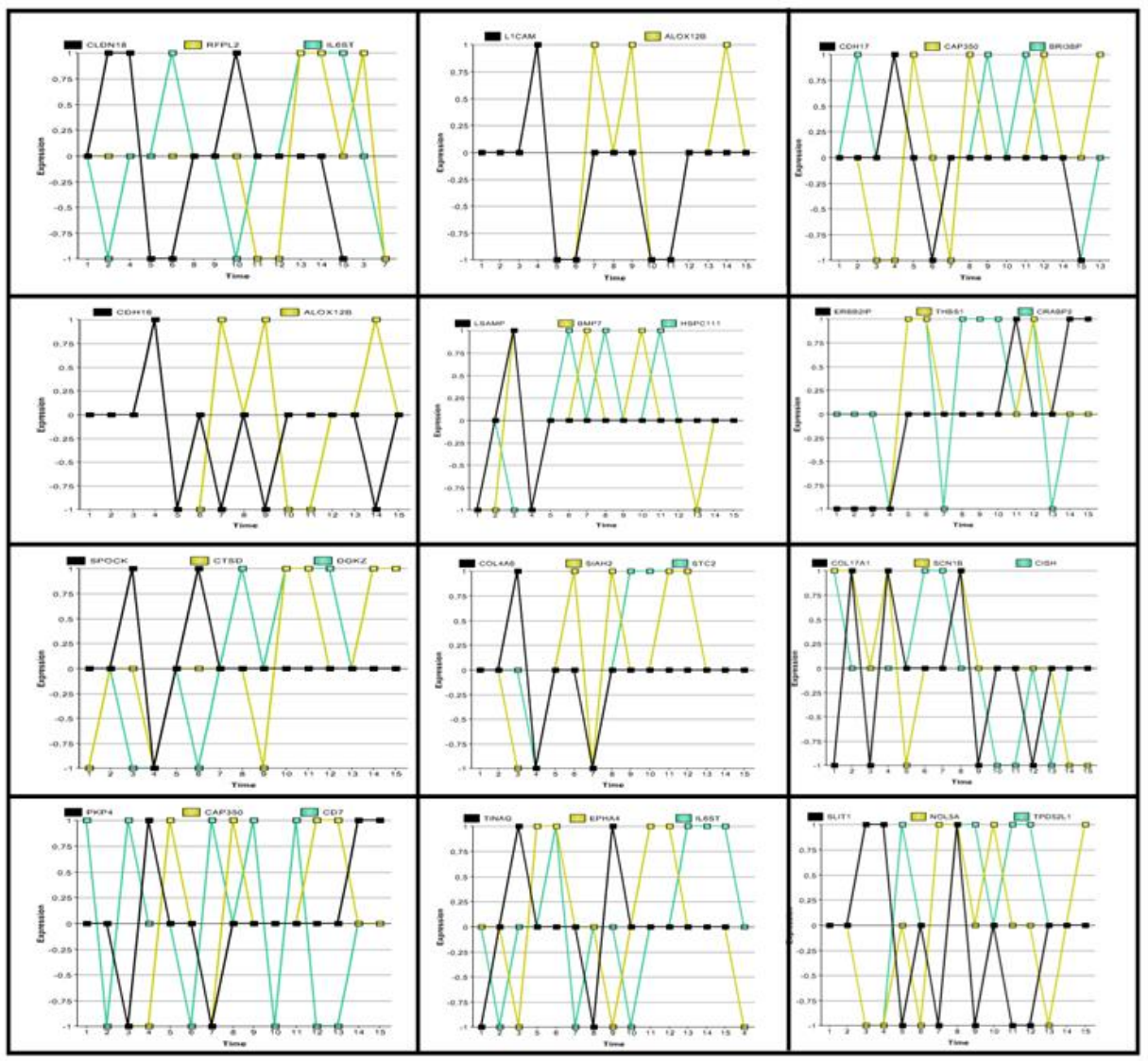




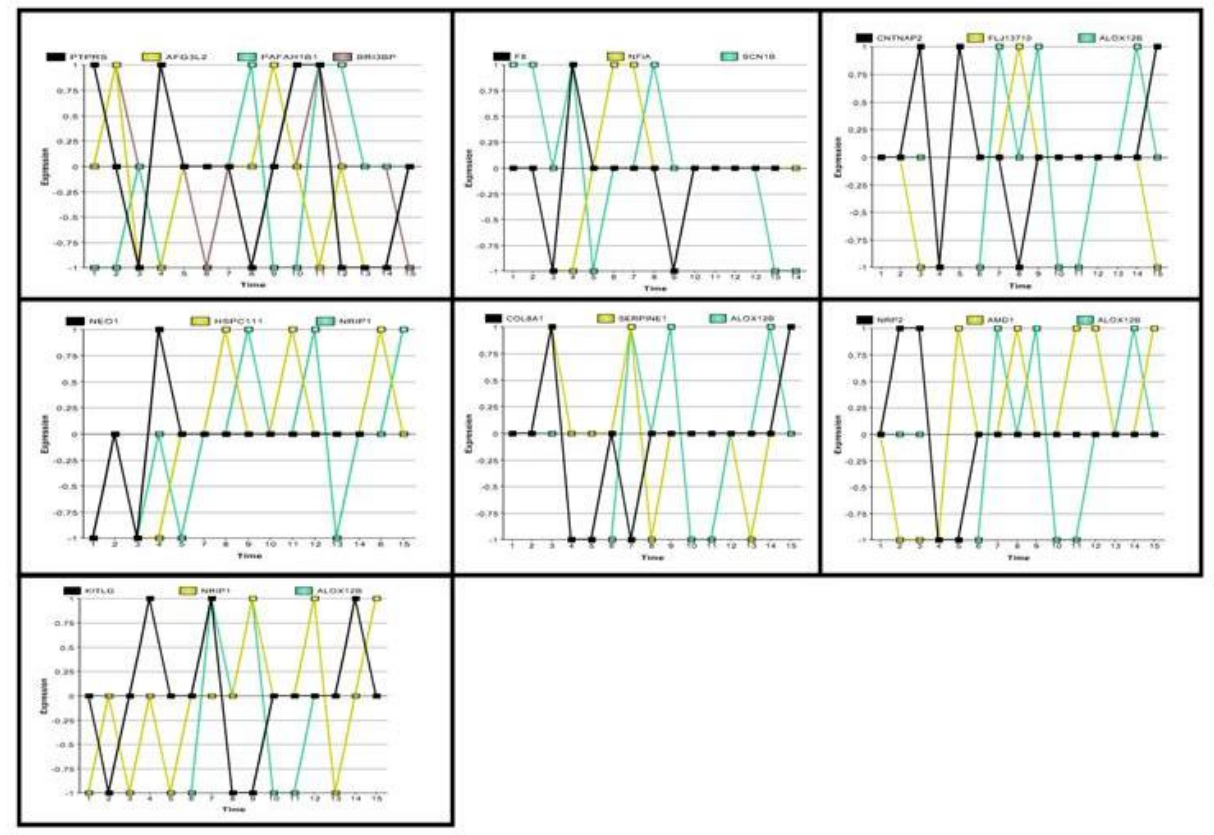

Figura C.2: Gráfico dos sinais dos genes relacionados à adesão celular 
Apêndice D

Conteúdo do DVD 
O DVD em anexo é composto pelos seguintes pastas:

- bibliografia - as referências bibliográficas deste trabalho;

- trabalhos e apresentacoes - todos os trabalhos, apresentações orais, pôsteres em congressos e conferências, e artigos científicos submetidos. Estes trabalhos estão dispostos em sub-pastas com o nome contendo o ano de execução como prefixo do nome (por exemplo: 2007_ISMM, significa conferência ISMM em 2007);

- ucurve - programa executável ucurve.exe para ser rodado em ambiente Microsoft Windows ${ }^{\mathrm{TM}}$ com as seguintes sub-pastas:

- source - todos os programas fontes com seus códigos em Microsoft $\mathrm{C}++$;

- testes - testes feitos na Seção 3.4, separados em: edliu (testes biológicos), e Woperador (testes de imagens). Os arquivos com extensão ".dat" contêm os dados de entrada, ".log" os dados de saída e os arquivos ".bat" são arquivos de execução em lote;

- pipeline - programas relativos ao pipeline de algoritmos com as seguintes sub-pastas:

- database - script para geração do banco de dados $\mathrm{MySql}^{\mathrm{TM}}$;

- genes sementes - arquivos contendo o comando sql para obtenção dos genessementes e a lista dos genes-sementes para três passos do aalgoritmo;

- resultados - o grafo resultante (teste1_go.html) obtido do teste executado na Seção 4.2.5, com redirecionamentos para a tablas de predição e gráficos dos sinais de expressão;

- source - programas fontes do pipeline desenvolvidos em Microsoft Visual Studio $7.0^{\mathrm{TM}}$ :

* csv2dbf.prg - converte um arquivo separado por ";" para um arquivo DBF (usado para converter o arquivo edliu.csv em edliu.dbf);

* dbf_norm_new.prg - programa de normalização e discretização dos dados (armazenando os resultados em um banco DBF);

* go2dbf.prg - converte o arquivo de retorno genes_go.txt da pesquisa em "Gene Ontology Database" (<http://www.geneontology.org >) para um banco de dados DBF (edliugo.dbf);

* uploadgo.prg - move os dados do banco de dados DBF (edliugo.dbf) para o banco de dados $\mathrm{MySql}^{\mathrm{TM}}$;

* edliugo2kegg.prg - processa o arquivo de retorno (edliugo_kegg.txt) do "KEGG: Kyoto Encyclopedia of Genes and Genomes" (<http://www.genome.jp/kegg $>$ ) inserindo marcadores KEGG no banco de dados;

* test_insert.prg - inserção de um teste novo ou uma nova iteração para o pipeline, passando dados do conjunto de genes-sementes;

* edliunrm_process.prg - processamento do teste para todos os genes do banco de dados; 
* test2dot.prg - a partir de um arquivo contendo todas as iterações dos testes (por exemplo: teste1_go.txt), gera um arquivo ".dot" que serve de entrada para o pacote graphviz (<http://www.graphviz.org $>$ );

* map2html.prg - a partir das saídas ".imap" (por exemplo: teste1_go.imap) e ".gif" (por exemplo: teste1_go.gif) do pacote graphviz, gera o arquivo html (por exemplo: teste1_go.html) contendo o grafo resultante;

- source_web - programas fontes de análise desnvolvidos para a WEB em em Macromedia ColdFusion $^{\mathrm{TM}}$ :

* edliu.cfm - para analisar o banco de dados resultante;

* edliu_res.cfm - gera a apresentação das tabelas de predições a partir do banco de dados;

* edliugo_plot.cfm - gera a apresentação dos gráficos dos sinais de expressão;

- adhesion - arquivos $h t m l$ com genes-sementes (genes_sementes.html) e seus agrupamentos (genes_sementes_agrupamento.html); genes preditos (genes_preditos.html) e seus agrupamentos (genes_peditos_agrupamento.html); e genes de adesão celular obtidos (genes_adesao.html);

- tese - arquivos eletrônicos do texto deste trabalho, fontes Latex e imagens. 
Apêndice E

Publicações e apresentações em eventos científicos 


\section{E.1 Eventos científicos}

Os seguintes trabalhos foram publicados ou apresentados em eventos científicos durante o curso de doutorado:

"Biological System Representation By Dynamic Systems: the retinoic acid transcription control" Marcelo Ris, Junior Barrera, Helena Brentani. Pôster apresentado em: ICoBiCoBi: 1st. International Conference on Bioinformatics and Computational Biology, Maio de 2003, Riberão Preto, São Paulo, Brasil.

"Identification of Estrogen Transcription Control Network Using U-curve Algorithm" Marcelo Ris, Junior Barrera, Helena Brentani. Pôster apresentado em: ICoBiCoBi II: 2nd. International Conference on Bioinformatics and Computational Biology, Outubro de 2004, Angra dos Reis, Rio de Janeiro, Brasil.

"U-curve Search for Biological States Characterization and Genetic Network Design" Marcelo Ris, Junior Barrera, Helena Brentani. Publicação de resumo e apresentação oral em: GENSIPS 2005: IEEE International Workshop on Genomic Signal Processing and Statistics 2005, Maio de 2005, New Port, Rhode Island, USA.

"Representação de Sistemas Biológicos a Partir de Sistemas Dinâmicos: Controle da Transcrição a Partir do Estrógeno" Marcelo Ris, Junior Barrera, Helena Brentani. Publicação de resumo e apresentação oral em: I Simpósio de Iniciação Científica e Pós-Graduação do IME-USP, Outubro de 2005, São Paulo, São Paulo, Brasil.

"Dynamical System Modeling of the Estrogen Transcription Control Network" Marcelo Ris, Junior Barrera, Helena Brentani. Pôster apresentado em: X-Meeting - 1st. International Conference of the AB3C (Associação Brasileira de Bioinformática e Biologia Computacional) Outubro de 2005, Caxambu, Minas Gerais, Brasil.

"Dynamical System Modeling of the Estrogen Transcription Control Network" Marcelo Ris, Junior Barrera, Helena Brentani. Pôster apresentado em: ISMB 2006 - 14th. Annual International Conference On Intelligent Systems For Molecular Biology Agosto de 2006, Fortaleza, Ceará, Brasil.

"A branch-and-bound optimization algorithm for U-shaped cost functions on Boolean lattices" Marcelo Ris, Junior Barrera. Publicação de resumo e pôster apresentado em: SSP 2007 - IEEE Statistical Signal Processing Workshop 2007 Agosto 2007, Madison, WI, USA.

"Dynamical System Modeling of the Estrogen Transcription Control Network" Marcelo Ris, Junior Barrera, Helena Brentani. Pôster apresentado em: 10th International Meeting of MGED Setembro de 2007, Brisbane, Australia. 
"A branch-and-bound optimization algorithm for U-shaped cost functions on Boolean lattices" Marcelo Ris, Junior Barrera. Publicação de resumo e pôster apresentado em: ISMM 2007 - 8th. International Symposium on Mathematical Morphology Outubro de 2007, Rio de Janeiro, Rio de Janeiro, Brasil.

"A New Algorithm Pipeline for Transcription Control Network Modeling" Marcelo Ris, Junior Barrera. Pôster apresentado em: X-Meeting - 3rd. International Conference of the AB3C (Associação Brasileira de Bioinformática e Biologia Computacional) Novembro de 2007, São Paulo, São Paulo, Brasil.

\section{E.2 Arigos em revistas}

"A branch-and-bound optimization algorithm for U-shaped cost functions on Boolean lattices" Marcelo Ris, Junior Barrera, David C. Martins Jr. Artigo submetido para: IEEE Transactions Pattern Analysis and Machine Intelligence (PAMI)

"A New Algorithm Pipeline to Construct Gene Networks" Marcelo Ris, Junior Barrera, Helena Brentani. Artigo submetido para: BMC-Bioinformatics

"Cellular Adhesion Evidence of Estrogen Regulation Network" Marcelo Ris, Junior Barrera, Helena Brentani. Artigo submetido para: Genome Biology 


\section{Índice Remissivo}

órgãos reprodutores, 11

U-curve

método, 18

microarrays, 14

pipeline, 39

descrição do método, 40

adesão celular, 57, 62, 66, 70

algoritmo $U$-curve, 18

algoritmo $U$-curve, 17

conclusões, 36

resultados, 34

algoritmo U-curve, 1, 46

aliases, 41, 50

apoptose, 14

arestas bloqueadas, 6

arestas dirigidas, 6

arquitetura da rede genética, 1

bem determinado, 44

Bolstered Error, 44

branch-and-bound, 1, 10, 17, 18, 46

busca completa, 10, 17, 18

cadeia, 18, 21

cadeia de Markov, 7, 8

cadeia maximal, 18

cadeias alternativas, 33

testes, 34

Cdk7, 11

cell adhesion, 62, 70

ChIP-on-chip, 13

CHX-cycloheximide, 58

ciclo celular, 14

citoquinas, 14

clustering, 14, 43

co-ativadores, 11

coberto, 21
CoD, 44

complemento de um conjunto, 18

condição U-curve, 31,32

condição $U$-curve

teorema, 31

condição U-curve, 22

condicionalmente independente, 8

conjunto complementar, 26

conjunto parcialmente ordenado, 18

conjuntos de restrições, 22

Atualização, 31

constrição, 18

construção do maximal, 30

validação, 30

construção do minimal, 28

validação, 29

curse of dimensionality, 10

curva em U, 10, 17, 46

curvas com oscilações, 34

curvas em U, 17

custo, 41

custo mínimo, 18

dímero E2-ER, 11

decomponível em curvas em U, 18, 31

descolamento, 66

diagrama de Hesse, 36

diretamente regulados, 67

Discretização, 42

discretização, 41, 42

drogas anti-estrogênicas, 12

drogas inibidoras de aromatases, 12

dual, 29

E1, 11

$\mathrm{E} 2,11,49$

E3, 11

efeitos proliferativos, 11 
elemento de resposta, 11

elemento maximal, 21

elemento minimal, 21

elementos adjacentes, 22

elementos mínimos, 21

endométrio, 11

entrada, 5

Entropia, 9

entropia, 44

entropia condicional média, 9, 41, 44, 45, 58

entropia condicional média estimada, 45

ER negativo, 12

ER positivo, 12

$\mathrm{ER} \alpha, 11$

$\operatorname{ER} \beta, 11$

$\mathrm{ER}+, 12$

ER-, 12

ER- $\alpha, 11$

ER- $\beta, 11$

Erro de classificação, 44

erro de estimação, 10

esgotamento do mínimo, 22, 26, 27, 34

validação, 32

espaço de busca, 10

estado, 5

estocástico, 34

estrógeno, 11, 39, 49

vias clássicas, 11

estrógeno-dependentes, 11

estradiol, 11

estriol, 11

estrona, 11

exponencial, 46

FA, 11

fator de transcrição, 11, 43

fatores de crescimento, 11, 14

fatores de transcrição, 14

fenômeno peaking, 10

fosforilação, 11

framework, 37

freqüência limitante, 45

função critério, 10

função custo, 10, 18

análise, 44

função de transição, 5 função estocástica, 6

funções biológicas, 14, 41

funções de ativação, 11

genômica funcional, 14

Gene Ontology Consortium, 14, 41

Gene Ontology Database, 58

gene-alvo, 44

genes-sementes, 39, 41, 43, 57, 58

análise, 43

GF, 11

glândula mamária, 11

glândulas mamárias, 11

GO, 49

heurísticas, 10, 46

hormônio, 11

hormônios, 14

ICI, 58

identificação de preditores, 33

independente do tempo, 8

Informação Mútua, 9

intervalo, 18

KEGG, 14, 41, 49

limitantes, 42

lista de resultados, 22

mínimo esgotado, 22

mínimo local, 21

mínimos locais, 21

MAE, 44

mais determinística, 43

mal determinado, 44

mapeamento, 42

MAPK, 11

matriz de transição, 7

maximal, 18, 22

construção do, 30

MCF-7, 13

melhor conjunto preditor, 46, 58

melhor predito, 48

melhores preditos, 41

metástase, 66

microarray, 1, 5, 14, 67

materiais, 54, 67 
série temporal, 40

série-temporal, 14, 39

série-temporal (figura), 15

microarrays, 35

minimal

construção do, 28

morfologia matemática, 10

não-determinística, 7

Normalização, 42

normalização, 41, 42

o algoritmo U-curve, 58

O problema de otimizaçao de curvas em U, 18 oscilações, 33

PBN, 7

PGN, 1, 7, 39

PGNs, 57

pipeline, 1, 39, 40

algoritmos, 55

discussão, 50

representação, 40

resultados experimentais, 49

poset, 18, 19, 21

posets, 46

problema U-curve, 10

Procedimento de obtenção dos elementos minimais e maximais, 26

processo estocástico, 6

quase-deteriminística

hipótese, 9

quase-determinística, 8

ranking, 41, 48, 58

receptores, 14

Reconhecimento de Padrões, 10, 17, 41

Reconhecimentos de Padrão, 46

Rede Booleana Probabilística, 7

rede de expressão gênica, 5,13

rede genética, 1

Rede Genética Probabilística, 7

Rede Genética Probabilística, identificação da, 8

Redes Booleanas, 7

redes genéticas, 5,37
Redes Genéticas Probabilísticas, 1

redes genéticas probabilísticas, 57

região promotora, 5

regulado diretamente, 43

restrição, 21

resultados experimentais, 33

reticulado Booleano, 10, 17, 18

reticulado Booleano completo, 18, 26, 46

saída, vetor de, 5

SAGE, 1,6

SBS, 46

seleção de características, 10, 17, 41, 46

seleção de direção, 21

Sequential Backward Selection, 46

Sequential Floating Backward Selection, 46

Sequential Floating Forward Selection, 46

Sequential Forward Selection, 46

SFFS, 33, 34, 46, 58

SFS, 46

sistema dinâmico, 5

sistemas biológicos, 14

sistemas dinâmicos, 1

Stanford MicroArray, 49

T47-D, 13

tabela de predição, 6

tabelas de predições gráfico, 50

Tamoxifen, 12

time-course microarray, 14

transdução de sinais, 14

translação-invariante, 5

U-curve, vii

via de regulação, 14, 41

W-operadores, 10, 17, 33, 34, 37

teste, 34

ZR-75.1, 14 


\section{Referências Bibliográficas}

[1] N. Abramson. Information Theory and Coding. McGraw-Hill Book Co., Inc., New York, second edition, 1963.

[2] M. Ashburner, C. A. Ball, J. A. Blake, D. Botstein, H. Butler, J. M. Cherry, A. P. Davis, K. Dolinski, S. S. Dwight, J. T. Eppig, M. A. Harris, D. P. Hill, L. Issel-Tarver, A. Kasarskis, S. Lewis, J. C. Matese, J. E. Richardson, M. Ringwald, G. M. Rubin, and G. Sherlock. Gene ontology: tool for the unification of biology. Nature Genetics, 25:25-29, 2000.

[3] J. Barrera, R. M. Cesar-Jr, D. C. Martins-Jr, R. Z. N. Vencio, E. F. Merino, M. M. Yamamoto, F. G. Leonardi, C. A. B. Pereira, and H. A. del Portillo. Constructing probabilistic genetic networks of Plasmodium falciparum from dynamical expression signals of the intraerythrocytic development cycle, chapter 2, pages 11-26. Springer, 2006.

[4] Linda Björnström and Maria Sjöberg. Mechanisms of estrogen receptor signaling: Convergence of genomic and nongenomic actions on target genes. Molecular Endocrinology, 19(4):833-842, 2005.

[5] U. Braga-neto and E. R. Dougherty. Bolstered error estimation. Pattern Recognition, $37: 1267-1281,2004$.

[6] D. R. Coman. Adhesiveness and stickiness: Two independent properties of the cell surface. Cancer Research, 1:1436-1438, 1961.

[7] K. R. Coser, J. Chesnes, J. Hur, S. Ray, K. J. Isselbacher, and T. Shioda. Global analysis of ligand sensitivity of estrogen inducible and suppressible genes in mcf7/bus breast cancer cells by dna microarray. PNAS, 100(24):13994-9, 2003.

[8] E. R. Dougherty, S. Kim, and Y. Chen. Coefficient of determination in nonlinear signal processing. Signal Processing, 80:2219-2235, 2000.

[9] R. O. Duda, P. E. Hart, and D. G. Stork. Pattern Classification, volume 1, pages 1-19. Wiley-Interscience, 2nd edition, 2000.

[10] D. Endy and R. Brent. Modelling cellular behaviour. Nature, 409:391-395, 2001.

[11] J. I. Fidler. Origin and biology of cancer metastasis. Cytometry, 10:673-680, 1989.

[12] A. Frank, D. Geiger, and Z. Yakhini. A distance-based branch and bound feature selection algorithm. In Proceedings of the 19th Annual Conference on Uncertainty in Artificial Intelligence (UAI-03), pages 241-248, San Francisco, CA, 2003. Morgan Kaufmann Publishers. 
[13] J. Frasor, J. M. Danes, B. Komm, K. C. N. Chang, C. R. Lyttle, and B. S. Katzenellenbogen. Profiling of estrogen up- and down-regulated gene expression in human breast cancer cells: Insights into gene networks and pathways underlying estrogenic control of proliferation and cell phenotype. Endocrinology, 144(10):4562-4574, 2003.

[14] C. Förster, S. Mäkela, A. Wärri, Silke Kietz, David Becker, Kjell Hultenby, Margaret Warner, and J. Gustafsson. Involvement of estrogen receptor $\beta$ in terminal differentiation of mammary gland epithelium. PNAS, 99(24):15578-15583, 2002.

[15] G. Hardiman. Microarray platforms - comparison and contrasts. Pharmacogenics, 5:487$502,2004$.

[16] R. F. Hashimoto, E. R. Dougherty, M. Brun, Z. Z. Zhou, M. L. Bittner, and J. M. Trent. Efficient selection of feature sets possessing high coefficients of determination based on incremental determinations. Signal Processing Special issue: Genomic signal processing, 83(4):695-712, 2003.

[17] R. F. Hashimoto1, S. Kim, I. Shmulevich, W. Zhang, M. L. Bittner, and E. R. Dougherty. Growing genetic regulatory networks from seed genes. Bioinformatics, 20:1241-1247, 2004.

[18] R. O. Hynes. Integrins: Versatility, modulation, and signaling in cell adhesion. Cell, 69:1125, 1992.

[19] A. K. Jain, R. P. W. Duin, and J. Mao. Statistical pattern recognition: A review. IEEE Transactions on Pattern Analysis and Machine Intelligence, 22(1):4-37, 2000.

[20] V. X. Jin, Y. W. Leu, S. Liyanarachchi, H. Sun, M. Fan, K. P. Nephew, T. H. Huang, and R. V. Davuluri. Identifying estrogen receptor $\alpha$ target genes using integrated computational genomics and chromatin immunoprecipitation microarray. Nucleic Acids Research, 32(22):6627-35, 2004.

[21] H. De Jong. Modeling and simulation of genetic regulatory systems: A literature review. Journal of Computational Biology, 9:67-103, 2002.

[22] D. C. Martins Jr, R. M. Cesar Jr, and J. Barrera. W-operator window design by minimization of mean conditional entropy. Pattern Analysis $\&$ Applications, 9:139-153, 2006.

[23] S. A. Kauffman. The Origins of Order, Self-Organization and Selection in Evolution, pages 441-520. Oxford University Press, New York, 1st edition, 1993.

[24] W. P. Kuo, T. K. Jenssen, A. J. Butte, L. O. Machado, and I. S. Kohane. Analysis of matched mrna measurements from two different microarray technologies. Bioinformatics, 18:405-412, 2002.

[25] A. S. Levenson, I. L. Kliakhandler, K. M. Svoboda, K. M. Pease, S. A. Kaiser, J. E. Ward III, and V. C. Jordan. Molecular classification of selective oestrogen receptor modulators on the basis of gene expression profiles of breast cancer cells expressing oestrogen receptor

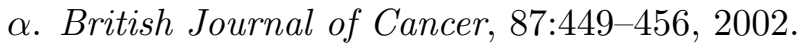


[26] C. Lin, A. Ström, V. B. Vega, S. L. Kong, A. L. Yeo, J. S. Thomsen, W. C. Chan, B. Doray, D. K. Bangarusamy, A. Ramasamy, L. A. Vergara, S. Tang, A. Chong, V. B. Bajic, L. D. Miller, J. Gustafsson, and E. T. Liu. Discovery of estrogen receptor $\alpha$ target genes and response elements in breast tumor cells. Genome Biology, 5(9):1-18, 2004.

[27] S. Nakariyakul and D. P. Casasent. Adaptive branch \& bound algorithm for selecting optimal features. Pattern Recognition Letters, 28:1415-1427, 2007.

[28] S. Nilsson, S. Mäkelä, E. Treuter, M. Tujague, J. Thomsen, G. Andersson, E. Enmark, K. Pettersson, M. Warner, and J. Gustafsson. Mechanisms of estrogen action. Physiological Reviews, 81(4):1535-1565, 2001.

[29] H. Ogata, S. Goto, K. Sato, W. Fujibuchi, H. Bono, and M. Kanehisa. Kegg: kyoto encyclopedia of genes and genomes. Nucleic Acids Res, 27:29-34, 1999.

[30] H. Oka, H. Shiozaki, K. Kobayashi, M. Inoue, H. Tahara, T. Kobayashi, Y. Takatsuka, N. Matsuyoshi, S. Mirano, M. Takeichi, and T. Mori. Expression of e-cadherin cell adhesion molecules in human breast cancer tissues and its relationship to metastasis. Cancer Research, 53:1696-1701, 1993.

[31] S. Peddada, E. Lobenhofer, L. Li, C. Afshari, C. Weinberg, and D. M. Umbach. Gene selection and clustering for time-course and dose-response microarray experiments using order-restricted inference. Science, 19:834-841, 2003.

[32] P. Pudil, J. Novovicová, and J. Kittler. Floating search methods in feature selection. Pattern Recognition Letters, 15:1119-1125, 1994.

[33] M. Ris and J. Barrera. A branch-and-bound optimization algorithm for u-shaped cost functions on boolean lattices. In Proceedings of the 8th International Symposium on Mathematical Morphology, volume 2, pages 55-56, Rio de Janeiro, RJ, 2007.

[34] M. Schena. DNA microarrays: A Practical Approach. Oxford University Press, 1st edition, 1999.

[35] M. Schena, D. Shalon, R. Davis, and P. O. Brown. Quantitative monitoring of gene expression patterns with a complementary dna microarray. Science, 270:467-470, 1995.

[36] I. Shmulevich, E. R. Dougherty, S. Kim, and W. Zhang. Probabilistic boolean networks: a rule-based uncertainty. Bioinformatics, 18(2):261-274, 2002.

[37] I. Shmulevich, E. R. Dougherty, and W. Zhang. Gene perturbation and intervention in probabilistic boolean networks. Bioinformatics, 18(2):1319-1331, 2002.

[38] C. Sima, U. Braga-Neto, and E. R. Dougherty. Superior feature-set ranking for small samples using bolstered error estimation. Bioinformatics, 21(7):1046-1054, 2005.

[39] P. Somol and P. Pudil. Fast branch \& bound algorithms for optimal feature selection. PAMI, 26(7):900-912, July 2004. 
[40] Z. Wang, J. Yang, and G. Li. An improved branch \& bound algorithm in feature selection. In Rough Sets, Fuzzy Sets, Data Mining, and Granular Computing: 9th International Conference, Lecture Notes in Computer Science, pages 549-556, Chongqing, China, May 2003. Springer Berlin / Heidelberg.

[41] A. Weisz, W. Basile, C. Scafoglio, L. Altucci, F. Bresciani, A. Facchiano, P. Sismondi, L. Cicatiello, and M. Bortoli. Molecular identification of er $\alpha$-positive breast cancer cells by the expression profile of an intrinsic set of estrogen regulated genes. Journal Cellular Physiology, 200(3):440-450, 2004.

[42] M. L. Whitfield, L. K. George, G. D. Grant, and C. M. Perou. Common markers of proliferation. Nature Reviews Genetics, 6:99-106, 2006.

[43] S. Yang and P. Shi. Bidirectional automated branch and bound algorithm for feature selection. Journal of Shanghai University, 9(3):244-248, 2005.

[44] X. Zhou, X. Wang, and E. R. Dougherty. Construction of genomic networks using mutualinformation clustering and reversible-jump markov-chain-monte-carlo predictor design. Signal Processing, 83:745-761, 2003.

[45] B. T. Zhu and A. H. Conney. Functional role of estrogen metabolism in target cells: review and perspectives. Carcinogenesis, 19(1):1-27, 1998. 